
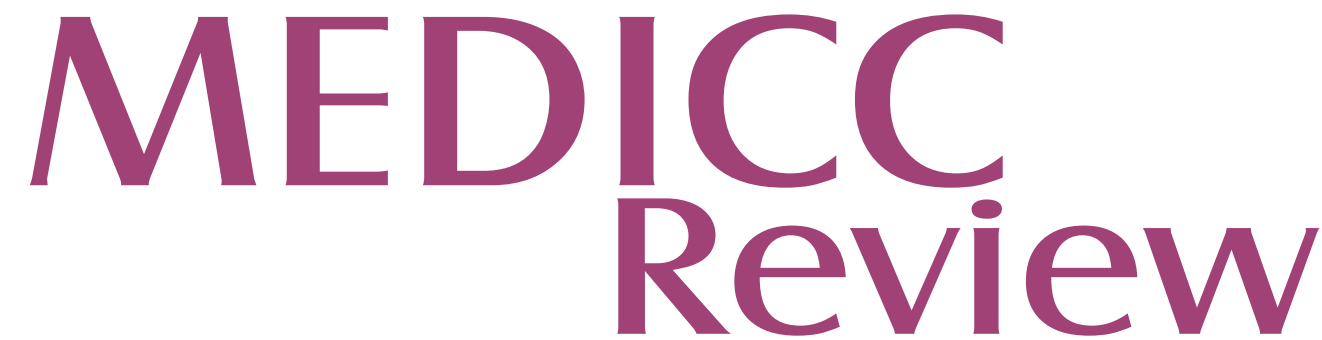

October 2020

Vol 22, No 4

Nutrition \& Alzheimer Disease in Older Cuban Adults

Liver Cirrhosis Deaths in Cuba

\title{
On COVID-19
}

Cuban Vaccine Trials

PAHO on Cuba's Pandemic Response

Global Review of Transmission Routes

$\begin{array}{r:c}\text { COVID-19: } & 24 \\ \text { First } 100 \text { Days in Cuba } & 4 \\ \text { Silent Hypoxemia's } & 05 \\ \text { Urgent Dilemma } & 07 \\ \text { Sounding the Alarm } & \\ \text { on Kidney Damage } & 07 \\ \text { Regaining Older-Adult } & 09 \\ \text { Mental Health } & 03\end{array}$

40

35

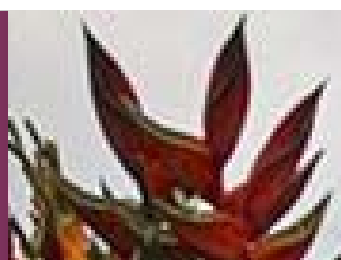

10
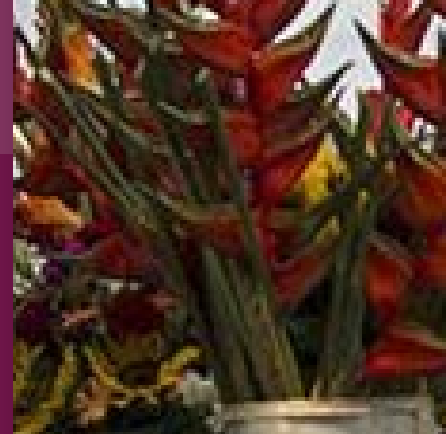

20

51

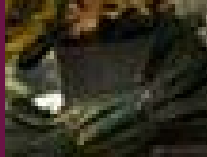

si

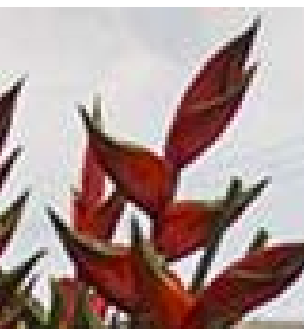

at
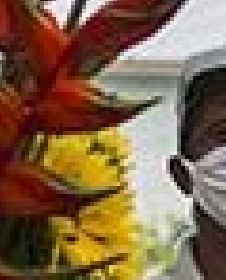

0
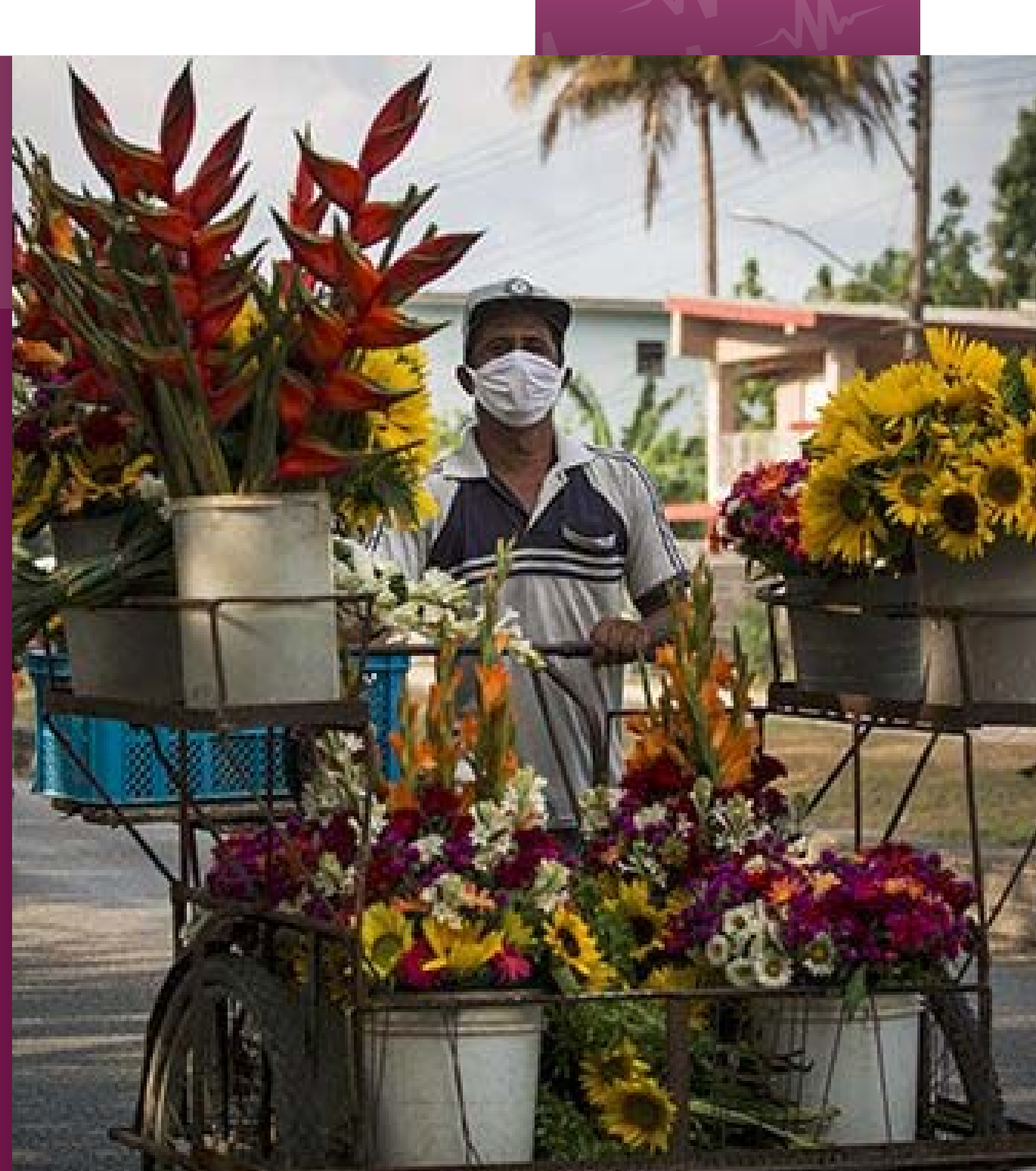


\section{PLANETARY HEALTH ANNUAL MEETINO APRIL 19-21, 2021}

Universidade de São Paulo, Brazil
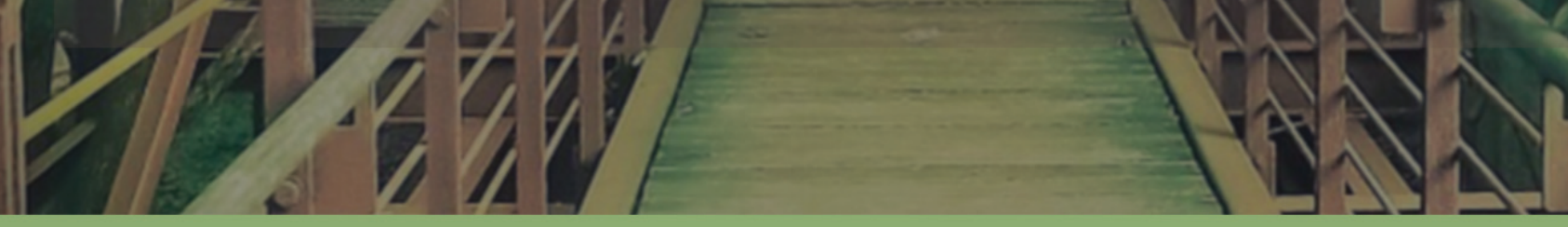

Planetary Health for All: Bridging Communities to Achieve the Great Transition

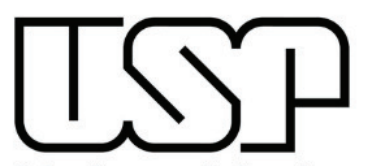

Universidade de São Paulo

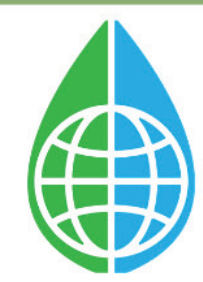

P L A N E T A R Y

H E A L T H

A L L I A N C E

planetaryhealthannualmeeting.com

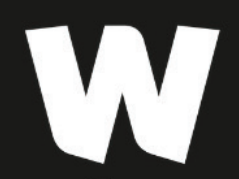

welloome 


\section{MEDICC Review}

October 2020, Vol 22, No 4

EDITORIAL

4

ABOUT THE CONTRIBUTORS

6

\section{LETTERS}

8

\section{INTERVIEW}

10

CUBA'S WOMEN OF SCIENCE:

SOBERANA, Cuba's COVID-19 Vaccine Candidates:

Dagmar García-Rivera PhD

Director of Research, Finlay Vaccine Institute

Conner Gorry MA

Early Action, Applied Research \& Collaboration to Combat COVID-19:

María Guadalupe Guzmán MD PhD DSc

Director, Reference Center for Research \& Diagnosis, Pedro Kourí Tropical

Medicine Institute, Havana

Gisele Coutin MD MS and Conner Gorry MA

A PAHO Perspective on COVID-19 in Cuba

José Moya MD MPH PhD

PAHO/WHO Permanent Representative in Cuba

Gail A. Reed MS

Ahora se habla más de lo frágiles que somos, y se hace más presente la pregunta acerca de cuáles son las verdaderas prioridades Reflexiones de la escritora española Belén Gopegui (Spanish only) Lila Castellanos Serra PhD DSc

\section{FEATURE}

27 Fallen in the Face of COVID-19:

Graduates of Cuba's Latin American School of Medicine (ELAM)

Gail Reed MS

\section{POLICY \& PRACTICE}

29 COVID-19 in Cuba: Assessing the National Response

Enrique Galbán-García MD PhD, Pedro Más-Bermejo MD PhD DSc

\section{ORIGINAL RESEARCH}

Characterization of Deaths from Cirrhosis of the Liver in Cuba, 1987-2017

Plácido Pedroso-Flaquet MD PhD, et al.

40

Levels of Vitamins and Homocysteine in Older Adults with

Alzheimer Disease or Mild Cognitive Impairment in Cuba

Yeneisy Lanyau-Domínguez MS PhD, et al.

\section{SHORT ARTICLE}

48 Determination of Reference Values for Double-Negative T Lymphocytes in Cuban Adults

Carlos Agustín Villegas-Valverde MD MS, et al.
Editor-in-Chief

C. William Keck MD MPH FACPM

Executive Editor

Gail Reed MS

Senior Editor, English Edition Caitlin Baird PhD

Senior Editor

Conner Gorry MA

Primary Issue Coordinator

Jorge Bacallao PhD DSc

Issue Coordinators

Alina Alerm MD MS

Lila Castellanos PhD DSc

Gisele Coutin MD MS

Esther María Fajardo MS

Editorial Associates

Anna Kovac

Annet Sánchez

Copy Editor

Carolyn Gorry

Communications Consultant

Elizabeth Sayre MA

Publishing \& Circulation

Aram Álvarez MFA

Silvia García

Yenny Leal

Translators

Pamela Boyle

Roxane K. Dow MA

Lyle Prescott

MEDICC Review is indexed in:

MEDLINE $/$ PubMed $^{\circledR}$

1 Clarivate Analytics
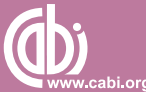

Global Health

Tropical Diseases Bulletin

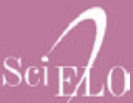

ELSEVIER

EMBASE

EBSCO

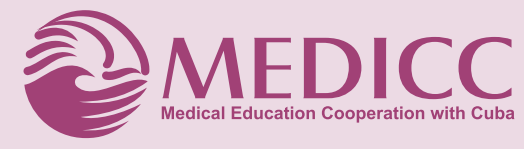

MEDICC Review is a unique open-access platform for Latin American and Caribbean praxis addressing today's critical interactions between human health, development of sustainable societies, and the health of our planet. Drawing upon the contributions of the region in social medicine social movements, rich diversity and scientific prowess, Latin America and Caribbean authors published in the journal can help fill gaps in thinking and evidence sorely needed to build a sustainable future and a hopeful legacy for future generations. We look forward to contributing to increased visibility for their work and to its positive impact on both regional integration and worldwide solutions.

MEDICC Review is published by MEDICC, a US nonprofit organization founded in 1997, based in Oakland, California, USA, and dedicated to US, Cuban and global health cooperation and equity.

MEDICC Review online (ISSN 1527-3172) is an openaccess publication: see our Creative Commons License online for details.

www.mediccreview.org - Copyright @ 2020, MEDICC Review 


\section{MEDICC Review}

\section{October 2020, Vol 22, No 4}

\section{REVIEW ARTICLE}

51 SARS-CoV-2 Transmission Channels: A Review of the Literature Ekram W. Abd El-Wahab MBChB MPH PhD, et al.

\section{PERSPECTIVE}

70 Cuban Contributions to Latin American Clinical Care and Research on Diabetes and Pregnancy

Jeddú Cruz-Hernández MD MS, et al.

\section{TESTIMONY}

$74 \quad$ La voz de una enfermera desde la zona roja (Spanish only)

Paula Guerra-Librero de Hoyos

\section{VIEWPOINT}

81 COVID-19, Your Pet and Other Animals: Are You at Risk? María Irian Percedo-Abreu DVM PhD

83 Not Infected but Physically and Mentally Affected: Older Cubans and COVID-19

Jesús Menéndez-Jiménez MD MPH

85 Silent or 'Happy' Hypoxemia:

An Urgent Dilemma for COVID-19 Patient Care Calixto Machado-Curbelo MD, PhD, FAAN

87 COVID-19 and the Kidneys: Risk, Damage and Sequelae Raúl Herrera-Valdés MD MS PhD DSc, et al.

\section{ABSTRACTS}

(3) Cuban Research in Current International Journals

(3) Special Abstracts Section COVID-19

(3) Available online only

\section{Cover photo: CUBADEBATE}


Neil Arya BASc MD CCFP FCFP

Director, Office of Global Health

Schulich School of Medicine and Dentistry

Western University, Canada

\section{Rifat Atun MBBS MBA FRCGP FFPH FRCP}

Professor of Global Health Systems

Director, Health Systems Cluster

Harvard University School of Public Health, USA

\section{Michael Bird MSW MPH}

Public Health Consultant, Kewa Pueblo Health Board

Urban Indian Health Commission

Albuquerque, New Mexico, USA

James Boex PhD MBA

Emeritus Professor of Medical Education

Univ. of Cincinnati College of Medicine, USA

\section{Peter Bourne MD MA}

Visiting Senior Research Fellow

Green Templeton College, University of Oxford, UK

\section{Alfred Brann MD}

Professor of Pediatrics

Emory University School of Medicine, USA

Jaime Breilh MD PhD MSc

Director, Health Department

Universidad Andina Simón Bolívar, Ecuador

\section{Paulo Buss MD MPH}

Emeritus Professor, Oswaldo Cruz Foundation (FIO-

CRUZ), Full Member, National Academy of Medicine Brazil

Pastor Castell-Florit MD PhD DSc

Director, National School of Public Health, Cuba

José F. Cordero MD MPH

Patel Distinguished Professor of Public Health

Chair, Department of Epidemiology and Biostatistics

College of Public Health, University of Georgia, USA

Yamila de Armas MD

Professor, National School of Public Health, Cuba

Maria Cecilia de Souza Minayo MS PhD

Professor of Sociology

National School of Public Health, Brazil

Timothy De Ver Dye PhD MS MA MPA

Professor, OB-GYN, Pediatrics,

Public Health Sciences and Medical Informatics

Univ. of Rochester School of Medicine and

Dentistry,USA

\section{Leith L. Dunn PhD}

Senior Lecturer \& Head, Institute for Gender

\& Development Studies, Mona Unit

University of the West Indies, Jamaica

Paul C. Erwin MD DrPH

Dean, University of Alabama at Birmingham

School of Public Health, USA
Lowell Gerson PhD

Professor Emeritus of Family \& Community Medicine

Northeast Ohio Medical University, USA

\section{Tee L. Guidotti MD MPH DABT}

Consultant, Occupational \& Environmental Health and Medicine, Toronto, Canada

Jean Handy PhD

Associate Professor of Microbiology \& Immunology

University of North Carolina School of Medicine, USA

Barbara J. Hatcher PhD MPH RN FAAN

Associate Professor, George Mason University

College of Nursing \& Health Sciences, USA

\section{Raúl Herrera MD PhD DSc}

Distinguished Professor, Medical University of

Havana; Chair, National Nephrology Group, Cuba

Eve J. Higginbotham SM MD

Vice Dean of Diversity \& Inclusion, University of

Pennsylvania, Perelmen School of Medicine, USA

Sharon K. Hull MD MPH

Founder and CEO, Metta Solutions, USA

C. William Keck MD MPH FACPM

Professor Emeritus, Family and Community

Medicine Northeast Ohio Medical University;

Chair, Council on Linkages, USA

Ann Marie Kimball MD MPH FACPM

Founder, APEC Emerging Infections Network;

Emeritus Professor, University of Washington, USA

Barry Kistnasamy MB ChB Mmed

Executive Director, National Institute for Occupational

Health \& the National Cancer Registry, South Africa

Patrick Kuma-Aboagye MB-BCH MPH

Deputy Director and Head

Reproductive and Child Health Department

Ghana Health Service, Ghana

Albert Kuperman PhD

Emeritus Associate Dean for Medical Education

Albert Einstein College of Medicine

Yeshiva University, USA

Margaret Larkins-Pettigrew MD MEd MPPM

Asst. Professor, Global Health/OB-GYN and Repro-

ductive Biology, Univ. Hospitals, Case Medical Center

\& MacDonald Women's Hospital, USA

Linh Cu Le MD MSc PhD

Associate Professor of Public Health

Vinmec International Hospital JSC, Viet Nam

Noni MacDonald MD MSc FRCPC FCAHS

Professor of Pediatrics and Computer Science

Dalhousie University, Canada

\section{Pedro Más MD PhD DSc}

Full Professor, Medical University of Havana

Senior Researcher, Pedro Kourí Tropical Medicine

Institute, Cuba
Nancy A. Myers PhD RN

Vice President, Leadership \& System Innovation American Hospital Association Center for Health Innovation, USA

Daniel J. Ncayiyana MD FACOG

Emeritus Professor, University of Cape Town

South Africa

F. Javier Nieto MD PhD

Dean, College of Public Health \& Human Sciences

Oregon State University, USA

\section{Jorge Pérez MD MS}

Adviser to the Director and Full Professor

Pedro Kourí Tropical Medicine Institute, Cuba

Patricia Rodney PhD MPH RN

Partners in Health, Education and Development USA

María Isabel Rodríguez MD

Health and Education Advisor to the President of the Republic, El Salvador

F. Douglas Scutchfield MD FACPM FAAP

Peter P. Bosomworth Professor of Health Services Research and Policy, University of Kentucky

Colleges of Public Health and Medicine, USA

Stuart G. Shanker DPhil MA

Distinguished Research Professor of Philosophy and Psychology; Director, Milton \& Ethel Harris

Research Initiative, York University, Canada

\section{Augusto Sola MD}

Neonatologist, St Jude's Hospital and Children's

Hospital, Orange County, California, USA

Ronald St. John MD MPH

President, St. John Public Health Consulting

International, Canada

Pedro Urra MS

Full Professor, University of Havana, Cuba

Pedro A. Valdés-Sosa MD PhD

Deputy Director, Neuroscience Center, Cuba

Luis F. Vélez MD MPH PhD

Director, Program Development, Evaluation and Quality Improvement, DePelchin Children's Center, USA

Howard Waitzkin MD PhD FACP

Distinguished Professor Emeritus

University of New Mexico, USA

Suwit Wibulpolprasert MD

Senior Advisor on Disease Control

Ministry of Public Health, Thailand

Paul Worley MBBS PhD FACRRM FRACGP Emeritus Professor of Rural Medical Education Prideaux Centre for Research in Health Professions Education, Flinders University, Australia
MEDICC Review (ISSN 1555-7960) is published quarterly by MEDICC (Medical Education Cooperation with Cuba) in January, April, July \& October.

Submissions MEDICC Review publishes original peer-reviewed articles by Cuban and international authors. Send letters to editors@mediccreview.org. Guidelines for authors at www.mediccreview.org.

Open Access MEDICC Review online (ISSN 1527-3172) is an Open Access publication; articles may be reproduced with proper attribution under Creative Commons License (www.mediccreview.org).

Advertising at www.mediccreview.org or write admin@mediccreview.org fo ad swaps. Acceptance of advertising does not imply endorsement.
Ethics Opinions expressed in articles and letters in MEDICC Review are the views of their authors, and do not necessarily reflect those of the Editors, publishers or Editorial Board. Responsibility for originality of manuscripts, free of plagiarism or fraud, rests with the authors. MEDICC Review will retract any article found to contain plagiarized or fraudulent content.

Reprints Articles in the 'Reprints' section of MEDICC Review print edition may be reproduced or distributed only authorized by the original copyright holder.

Print Copies Selected readers receive the print edition. Contact admin@mediccreview.org for more information, and for prices of back issues or bulk copies. 


\section{COVID-19 and the Rocket Science of Public Health}

We are all fatigued, frazzled. Many of us have lost too many and too much, and still more will suffer long-term physical and mental effects. A strange geography has cropped into our lexicon: states, provinces and entire countries mapped by their rates of COVID-19, telling us how dangerous it is to go outside, go to work or school. It is also the geography of health care, leadership and policies that aim to protect people first—or not—the willingness to embrace the simply brilliant and brilliantly simple lessons of public health.

Coming for all of us, the entire human population, the disease has laid bare the social, economic and racial disparities between and within nations. It has exposed our failings brutally. Yet it has also revealed bright spots on the map that denote our resolve. The result is, indeed, a marked difference in how countries and people are faring, determined as much by the vagaries of the virus as by the public health protections already in place.

What we are learning from regions like the Caribbean, and from countries as diverse as Vietnam, Uruguay, Cuba and New Zealand, is that success in battling the pandemic is determined neither by blithe ignorance nor by blinding rhetoric, but by subtler, determined efforts born of a sense of public and personal responsibility, well-placed faith in sound healthcare systems that revere prevention, plus that elusive ingredient of empathy. Our collective predicament has driven home one of the basic tenants of public health: the success of any one public health campaign is determined not fundamentally by the amount of material resources, but rather how resources have historically been allocated to build in protection for entire populations.

Countries that had not made such investments in the public good-in scientific literacy and in comprehensive, functional and accessible healthcare-are adrift, their populations infinitely more vulnerable.

Nowhere is this more evident than in the Americas, the pandemic's most recent epicenter and home to its most glaring hot spots: the United States and Brazil. Latin America, already the world's most unequal region by any measure, is faced with a depression the likes of which has not been seen for decades. And the poor, the informal sector, the indigenous and Afro-descendent, the women....are already its most egregious, predictable victims. Yet, Uruguay, sandwiched between Brazil and Argentina, is doing much better. So is Cuba, the country and people shouted about, but so little reflected upon.

In this issue, we take a much closer look at what has galvanized public health efforts in Cuba, resulting in just over 6000 COVID-19 cases since the first were diagnosed last March, and fewer than 150 deaths. Perhaps it is Cuba that makes the clearest case for public health: its single, universal health system constituting an underlying, national grid already capable of prevention and care; an abundance of health professionals on the job; a strong primary healthcare subsystem accessible everywhere; an epidemiological surveillance network with experience facing down epidemics like dengue; a science and biotech capability poised to generate new medications and put old ones to work; a public schooled in public health. Not to mention that they early developed a national plan.

Two articles in this issue assess the Cuban response: one from inside the health system by Galbán and Más, and the other from the vantage point of the PAHO/WHO Permanent Representative in Havana, Dr José Moya, who also contemplates the country's current opening towards a "new normal" and the element of public trust in health care. He also refers to multilateralism and global solidarity as essential underpinnings for tackling the pandemic. In this respect, Cuban health professionals and medical educators have also provided examples of cooperation during COVID-19: 52 teams have served in 39 countries in Europe, Africa, Latin America and the Caribbean.

We dedicate the Feature in this issue to 17 young physicians who lost their lives to COVID-19 while serving in their countries. All were among the over 30,000 in 118 countries who had received scholarships from Cuba to study medicine at Havana's Latin American School of Medicine. Their average age was 35, reminding us of the thousands of health workers who have been felled by the virus on the front lines.

Cuban specialists in neurology, nephrology, mental health and veterinary medicine explore the seemingly infinite ramifications of the virus in the human body and beyond. Guzmán reviews the research and clinical practice involving COVID-19 patients at Cuba's Pedro Kourí Tropical Medicine Institute.

\section{Cuban researchers anticipate a vaccine in first half of 2021}

Cuba's Women of Science focuses on Dr Dagmar García who directs research at the Finlay Vaccine Institute in Havana, where efforts are concentrated on Phase I/II trials on the WHO-registered vaccine for COVID-19. In a classic case of burying the lead, at the interview's close she indicates that Cuban biotech will have a vaccine for the Cuban researchers anticipate a vaccine in first half of 2021. Cuba is the first and, at this writing, the only Latin American country that has produced a vaccine candidate in clinical trials, and is now moving to introduce others.

Cuban innovation in biotechnology, so important to patients in the country and worldwide, has been reinforced by the sheer necessity implied by stiffened US sanctions. The current US administration has taken some 120 new draconian measures against Cuba since 2019: everything from capping family remittances to barring US citizens from hotel stays on the island to eliminating US flights to every Cuban city but Havana. All apparently in a cynical drive to curry election votes among hardliners in Florida-who would perhaps be better served by more attention to the pandemic there.

Which brings us back to public health: Florida, with just twice Cuba's population, has registered over 762,000 cases and 16,000 deaths, according to The New York Times, or 3550 cases and 75 deaths per 100,000 population. In the USA as a whole, we see 8.4 million cases at this writing and 222,000 deaths, or 2525 cases and 67 deaths per 100,000 population. Comparing these data to Cuba, at 56 cases and just one death per 100,000 population, is reason enough to look at what Cuba is doing. 
In contrast, the US federal government's pandemic response has been muddled by racism, misinformation campaigns and the politicization of simple preventive measures like mask-wearing and social distancing. All of this has landed in the context of a health system so difficult to access and navigate that 27.5 million people simply cannot, even after extensive reform. And now, with the Supreme Court dangerously swerving to thwart the Affordable Care Act, those 8 million-and-counting may be dumped from insurance schemes after suffering COVID-19, the disease labeled a disqualifying 'pre-existing condition.' Thus, while in 2019, the Global Health Security Index ranked the United States as the country "most prepared to respond to an epidemic or pandemic," by this year, it has become a tragic example of what not to do when faced with a public health challenge of such magnitude.

However, misinformation and faulty science are not the exclusive purview of certain public officials: the challenges continue to involve new faces, evidenced by the Great Barrington Declaration, a manifesto that, in direct defiance of everything we know thus far about COVID-19, urges policies based on eventual development of herd immunity. In the absence of an effective vaccine, the proposal would mean millions of deaths worldwide. MEDICC
Review's Editor-in-Chief Dr C. William Keck has joined with thousands other scientists and health professionals in signing the John Snow Memo, a memorandum published by The Lancet that decries the strategies suggested in Barrington as both unethical and impractical; "ignoring sound public health advice" and "selling false hope that will predictably backfire."

As we move into the second year of the pandemic, one paper in this issue is particularly useful to help take stock: from Egypt, Dr Abd El-Wahab's extensive review of what has been learned worldwide about SARS-CoV-2 transmission channels.

COVID-19 is, fundamentally, a lesson, and one we can ill-afford to ignore. This is not the last pandemic we will face. It is likely not the worst. And certainly it is not the only challenge ahead for us as people sharing the same planet. What is working to stem COVID-19-a sense of collective responsibility and collaborative investment in population health, education and well-being, informed by the basic tenets of public health science-surely should guide us forward. Perhaps the most important lesson learned is that better results in any context boil down to leadership. $-1 /$ -

\section{The Editors}




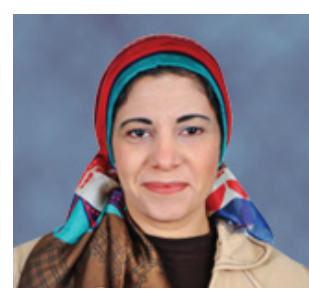

\section{Ekram W. Abd El-Wahab MBChB MPH PhD}

Physician specializing in tropical health with a doctoral degree in molecular and cellular biology. She is associate professor of tropical health at the High Institute of Public Health, Alexandria University, Egypt. She has studied in Egypt, Japan, France and the USA. She is an expert in early detection, prevention and control of communicable and non-communicable diseases.

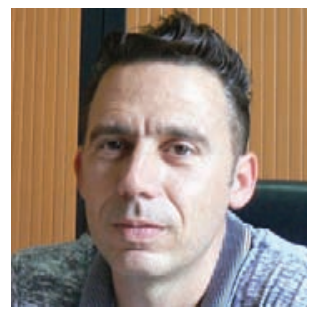

\section{Jeddú Cruz-Hernández MD MS}

Physician with dual specialties in family medicine and endocrinology, and master's degrees in comprehensive women's health care, atherosclerosis research and diagnostic procedures in primary health care. Dr Cruz heads the Working Group on Diabetes and Pregnancy at the Cuban Institute of Endocrinology's Center for Comprehensive Diabetic Care in Havana, Cuba, where he also serves as a member of the Scientific Council. He is responsible for the endocrinology portion of the Cuban Diabetes and Pregnancy Program.

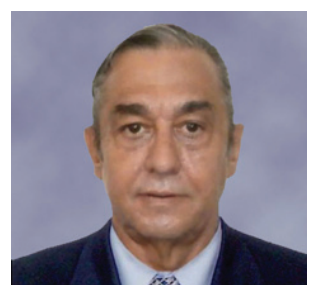

\section{Enrique Galbán-García MD PhD}

Physician specializing in epidemiology with a doctorate in public health. $\mathrm{Dr}$ Galbán is an epidemiologist at Cuba's national Gastroenterology Institute and the Medical University of Havana, where he is a senior researcher and full professor. He has been instrumental in development of the Cuban hepatitis $B$ and meningococcal $B$ vaccines. His research currently focuses on viral hepatitis, liver cirrhosis and colon cancer.

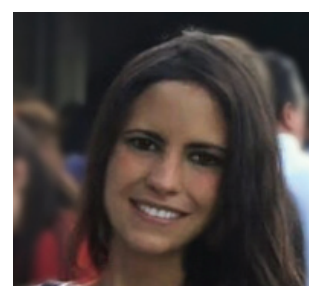

Paula Guerra-Librero de Hoyos

Nurse with a nursing degree from the Autonomous University of Madrid, Spain. Ms Guerra works in the Intensive Care Unit at the Puerta de Hierro University Hospital, a tertiary care university facility in Madrid, where she is currently serving on the front lines of the COVID-19 pandemic.

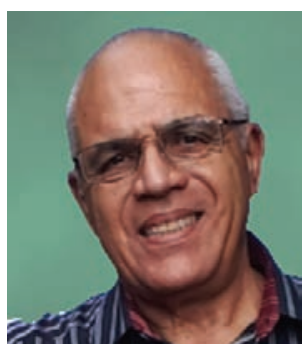

Raúl Herrera Valdés MD MS PhD DSc Nephrologist with a master's degree in epidemiology, a doctorate in medical sciences and a higher doctorate in science. Dr Herrera is a distinguished researcher at the Dr Abelardo Buch Lopez Nephrology Institute in Havana, Cuba, and full and consulting profesor at the Medical University of Havana. His research focuses on chronic kidney disease and in El Salvador, he has served as PAHO consultant for research on the epidemic of chronic kidney disease of uncertain etiology.

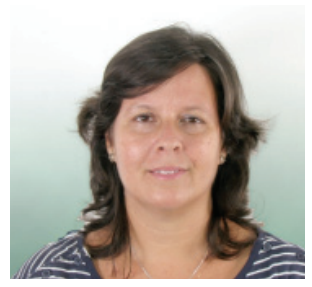

Yeneisy Lanyau-Domínguez MS PhD Biochemist with a master's degree in nutrition sciences and public health, and a doctorate in health sciences. $\mathrm{Dr}$ Lanyau is associate researcher and head of the Vitamins B and C Laboratory in the biochemistry department at the Cuban National Institute of Hygiene, Epidemiology and Microbiology (INHEM), in Havana, where she has worked for the past 25 years. Her current research focuses on interventions in and monitoring of nutrition in children and older adults.

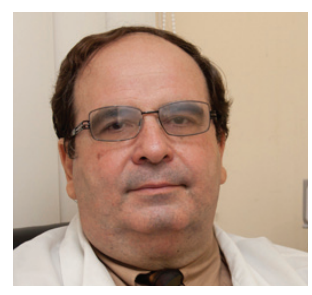

\section{Calixto Machado-Curbelo MD PhD FAAN}

Physician specializing in neurology and neurophisiology, with a doctorate in medical sciences. Dr Machado is full professor and senior researcher at the Institute of Neurology and Neurosurgery in Havana, Cuba, where he heads the Neurophysiology Laboratory. He is president of the Cuban Society of Clinical Neurophysiology, and chair of the Network on Defining Death of the International Bioethics Association

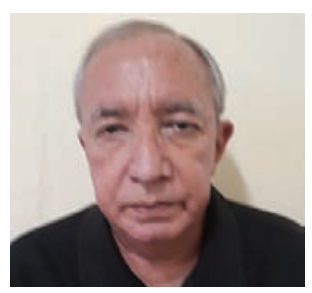

Pedro Más-Bermejo MD PhD DSc Epidemiologist, with a doctorate in medical sciences and a higher doctorate in science. Dr Más is full professor at the Pedro Kourí Tropical Medicine Institute, in Havana, Cuba, and adjunct professor in the department of Public Health and Tropical Medicine at Tulane University in the USA. He is a member of the Cuban Academy of Sciences, which awarded him the title of distinguished researcher. 


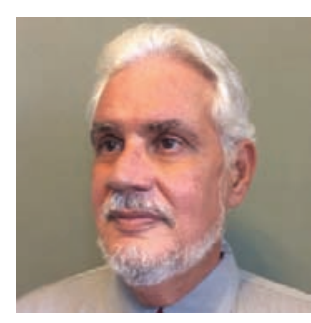

Jesús Esteban Menéndez-Jiménez MD MPH

Physician specializing in gerontology and geriatrics with a master's degree in public health and aging. Associate researcher and associate professor at the Medical University of Havana, Cuba, where he chairs the Rector's Advisory Committee on Geriatrics (CARE). Dr Menéndez is director of the WHO-PAHO Collaborating Center on Public Health and Aging.

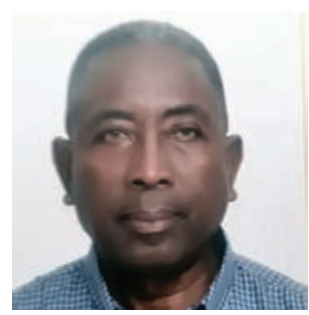

\section{Plácido Pedroso-Flaquet MD PhD}

Physician and epidemiologist with a doctorate in medical sciences. $\mathrm{Dr}$ Pedroso is currently advising the health ministry in Dominica, with a leave from his post as research director at Cuba's National Unity for Health Promotion and Disease Prevention (ProSALUD). $\mathrm{He}$ is full professor at the Medical University of Havana, Cuba. He has devoted over 30 years to dengue research and control in Cuba and has served as international advisor on infectious disease epidemiology in various countries, including in Haiti during the cholera epidemic.

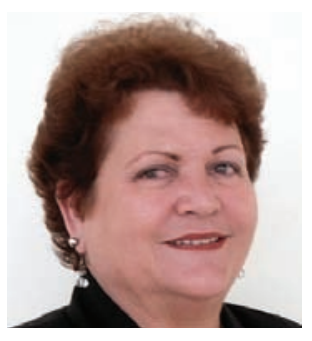

María Irian Percedo-Abreu DVM PhD Veterinarian with a doctorate in veterinary sciences. Dr Percedo is a senior researcher with the Division of Animal Health in the Clinical and Epidemiology Group at Cuba's National Center for Agricultural Health (CENSA), in San José de las Lajas, Cuba. She has won multiple awards for service and research and directs the Training Center for Disaster Reduction in Animals and Plants. Her research and activism focus on One Health, epidemiology, and disaster and disease reduction in animals

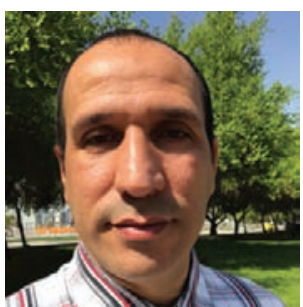

\section{Carlos Agustín Villegas-Valverde} MD MS

Physician with dual specialties in family medicine and immunology, and master's degrees in infectious diseases and medical education. Dr Villegas is on staff at Cuba's National Institute of Oncology and Radiobiology in Havana, where he is also associate researcher and is assistant professor at the Medical University of Havana. He is now participating in a study on stem cell therapy for COVID-19 patients. 


\section{RT-PCR USEFULNESS IN MICROBIOLOGICAL DISCHARGE DECISIONS FOR COVID-19 PATIENTS}

\section{To the Editors:}

The Cuban Ministry of Public Health's Protocol for Attention to COVID-19 Patients establishes that case confirmations are determined by positive virological tests of persons with and without symptoms.[1] These studies are carried out for SARS-CoV-2 by real-time polymerase chain reaction (RT-PCR) in specimens of respiratory mucosa collected via nasopharyngeal swab. The Protocol also establishes three types of discharge: microbiological (based on negative RT-PCR), clinical-imaging (no signs or symptoms and negative chest scan) and epidemiological (14 days after negative RT-PCR). A microbiological release from hospital is warranted when a patient tests negative by RT-PCR at nine days after testing positive.[1]

For organizing case management, it becomes important to assess the usefulness of this RT-PCR at nine days post-confirmation. At the Pedro Kourí Tropical Medicine Institute, we analyzed the percent of patients who tested negative on day 9, as well as those testing negative on days 10-14, 15-21 and 22-28. All COVID-19 patients released from the Institute from April through August 2020 were included: 153 total, 95 symptomatic and 58 asymptomatic.

RT-PCRs were negative on day 9 for $75 \%$ of cases (115), with statistically significant differences between symptomatic and asymptomatic patients: $68.4 \%$ of symptomatic (65) and $86.2 \%$ of asymptomatic (50) $(p=0.0228)$.

For the remaining groups, symptomatic and asymptomatic patients tested negative post diagnosis as follows:

- 10-14 days: 10 symptomatic (10.5\%) vs. 4 asymptomatic (6.9\%);

- 15-21 days: 15 (15.8\%) vs. 2 (3.4\%); and

- $22-28$ days: 5 (5.3\%) vs. $2(3.4 \%)$.

The fact that $75 \%$ of patients tested negative on day 9 validates the usefulness of the current clinical conduct and its impact on reducing hospital burdens, freeing up beds for other patients if necessary.

We thank Dr María Guadalupe Guzmán-Tirado and Dr Daniel González-Rubio for their revision of the findings expressed in this letter. -1 h

1. Ministry of Public Health (CU). Protocolo de actuación nacional para la COVID-19 [Internet]. Havana: Ministry of Public Health (CU); 2020 Aug [cited 2020 Aug 31]. 215 p. Available at: https://files.sld.cu/editorhome/files/2020/08/ VERSION-5-DEL-PROTOCOLO-PARA-PUBLICAR-13-DE-AGOSTO-2020 .pdf. Spanish.

Osvaldo Enrique Castro-Peraza MD MS (osvaldo@ipk.sld.cu), Pedro Kourí Tropical Medicine Institute, Havana, Cuba. https://orcid.org/0000 -0002-7208-099X

Alina Martínez-Rodríguez MD MS, Pedro Kourí Tropical Medicine Institute, Havana, Cuba. https://orcid.org/0000-0002-9946-9399

\section{COVID-19 AND DIABETES: HANDLE WITH CARE}

\section{To the Editors:}

As the latest issues of MEDICC Review reveal, the global scientific community is fully engaged in unraveling the mysteries of COVID-19, including its relationship to chronic conditions such as diabetes mellitus (DM), a frequent comorbidity with SARSCoV-2 infection. Various studies report up to $30 \%$ of persons with COVID-19 are diabetic,[1] and such patients are at greater risk of intrahospital deaths from the disease.[2]

Huang's meta-analysis in China reviewed 30 studies assessing 6452 cases showed that DM patients had worse prognosis (RR 2.38 [Cl 95\%: 1.88-3.03; $p<0.001]$ ) and higher risk of death (RR 2.12 [Cl 95\%: 1.44-3.11; $\mathrm{p}<0.001]$ ), severe COVID-19 (RR 2.45 [Cl 95\%: 1.79-3.35; $p<0.001]$ ) and disease progression (RR 3.31 [Cl 95\%: 1.08-10.14; $p=0.04]$ ).[3] Diabetic patients with compromised immune systems and those aged $>65$ years also had greater risk of dying from COVID-19.[4]

Among the physiopathological factors relating COVID-19 with DM is over expression of angiotensin converting enzyme 2 (ACE2), above all in those patients treated with ACE2 inhibitors for comorbidities or diabetic complications, as well as the cytokine storm induced by glucolipid disorders.

These observations give us ample warning of the need to protect DM patients in the context of COVID-19. However, circumstances provoked by the pandemic, in which specialist consults and follow up for these patients have been limited, can contribute to deteriorating disease control. The lack of physical activity coupled with the stress brought on by social isolation further aggravates the situation for those living with diabetes. Thus, it is left up to patients and their families to pay greater attention to self-care and safety measures.

Health systems and their professionals must seek alternatives that facilitate personalized medical care in the context of the pandemic, including telemedicine options. At the same time, health professionals are challenged to continuously update their knowledge concerning DM and its relation to COVID-19. - N

1. Li B, Yang J, Zhao F, Zhi L, Wang X, Liu L, et al. Prevalence and impact of cardiovascular metabolic diseases on COVID-19 in China. Clin Res Cardiol [Internet]. 2020 Mar 11 [cited 2020 Jul 10];109:531-8. Available at: https://doi .org/10.1007/s00392-020-01626-9

2. Zhou F, Yu T, Du R, Fan G, Liu Y, Liu Z, et al. Clinical course and risk factors for mortality of adult inpatients with COVID-19 in Wuhan, China: a retrospective cohort study. Lancet [Internet]. 2020 Mar 28 [cited 2020 Jul 10];395(10229):1054-62. Available at: https://doi.org/10.1016/S01406736(20)30566-3

3. Huang I, Lim MA, Pranata R. Diabetes mellitus is associated with increased mortality and severity of disease in COVID-19 pneumonia - A systematic review, meta-analysis, and meta-regression. Diabetes Metab Syndr [Internet]. 2020 Jul-Aug [cited 2020 Jul 10];14(4):395-403. Available at: https://doi org/10.1016/j.dsx.2020.04.018

4. Bello-Chavolla OY, Bahena-López JP, Antonio-Villa NE, Vargas-Vázquez A, González-Díaz A, Márquez-Salinas A, et al. Predicting mortality due to SARSCoV-2: a mechanistic score relating obesity and diabetes to COVID-19 outcomes in Mexico. J Clin Endocrinol Metab [Internet]. 2020 [cited 2020 Jul 10]. Available at: https://academic.oup.com/jcem/article/105/8/2752/5849337

Frank Hernández-García MD (frankhernandezgarcia1996@gmail.com; frank96@infomed.sld.cu), Medical University of Ciego de Ávila, Cuba. http://orcid.org/0000-0002-0142-0045 


\section{STRENGTHEN MEDICAL EDUCATION TO IMPROVE ATTENTION TO GERIATRIC HEALTH}

\section{To the Editors:}

In her MEDICC Review article earlier this year, Ponce-Laguardia emphasized the need for integrating social and psychological support in efforts to improve quality of life (QoL) for older Cuban adults.[1] With global life expectancy on the rise, health professions education should emphasize the importance of active aging and stress appropriate preparation of future doctors on competencies related to geriatric health concerns. In the Dominican Republic, a country of 10.8 million residents with $7.5 \%$ of the total population older than 65 years, this complementary training should be widely incorporated across medical schools.

To address this learning gap in our country, we suggest that medical curricula incorporate geriatrics training through three innovative strategies. First, by creating student interest groups, even through established national medical student organizations like Organización Dominicana de Estudiantes de Medicina (ODEM) that can develop student-run activities with community elders that focus on social interactions and health education. Second, by coordinating a community rotation with primary healthcare community centers (Unidad de Atención Primaria, UNAP) so that family doctors can supervise students and facilitate direct interactions with elders to highlight geriatric health concerns and stress the important role of preventive medicine in geriatric health and QoL. Third, by revising clinical rotations to include palliative or end of life training, in order for students to learn and strengthen essential competencies in preventive medicine, palliative care and communication skills with patients and families.

Integrating such academic community experiences into medical education can also highlight the value of the humanistic touch and more robust social and communication skills, as well as encourage students to seek community-serving opportunities and become involved in a wide range of wellness areas.

We would encourage expansion of this approach to other Latin American countries, to prepare medical students to lead community initiatives that promote adoption of healthy lifestyles and encourage social and community support for older adults. Such action can address current learning gaps about geriatric medicine in medical curricula, offer skills-based training in geriatric health concerns, and provide valuable leadership training for these future physicians as the world experiences a demographic shift towards aging populations. $-1 /$ -

1. Ponce-Laguardia TM. Educational program for retiring persons: a community experience in Cienfuegos Province, Cuba. MEDICC Rev [Internet]. 2020 Jan [cited 2020 Aug 7];22(1):28-32. Available at: https://mediccreview.org/educa tional-program-for-retiring-persons-a-community-experience-in-cienfuegos -province-cuba/

Sabrina Verdeja-Vicente (sverdeja@est.unibe.edu.do), Iberoamerican University (UNIBE) School of Medicine and Organización Dominicana de Estudiantes de Medicina (ODEM), Santo Domingo, Dominican Republic.

Amanda Raquel Villalona-Lluveres (avillalona1@est.unibe.edu.do), Iberoamerican University (UNIBE) School of Medicine and Organización Dominicana de Estudiantes de Medicina (ODEM), Santo Domingo, Dominican Republic. 


\section{SOBERANA, Cuba's COVID-19 Vaccine Candidates: Dagmar García-Rivera PhD}

\section{Director of Research, Finlay Vaccine Institute}

\section{Conner Gorry MA}

On August 13, 2020, Cuba's national regulatory agency, the Center for Quality Control of Medicines, Equipment and Medical Devices (CECMED), authorized clinical trials for SOBERANA 01-Cuba's first vaccine candidate and the first from Latin America and the Caribbean. On August 24, parallel Phase I/II double blind, randomized, controlled clinical trials were launched at clinical sites in Havana to evaluate the vaccine's safety and immunogenicity. Analysis of results and development of different formulations are currently under way and Phase III clinical trials are planned for early 2021. At the time of writing, a second vaccine candidate, SOBERANA 02 , was in late-stage development and preparing to begin separate trials this fall.

Cuba's biotech industry, comprised of more than 30 research institutes and manufacturing companies in the state-owned conglom-

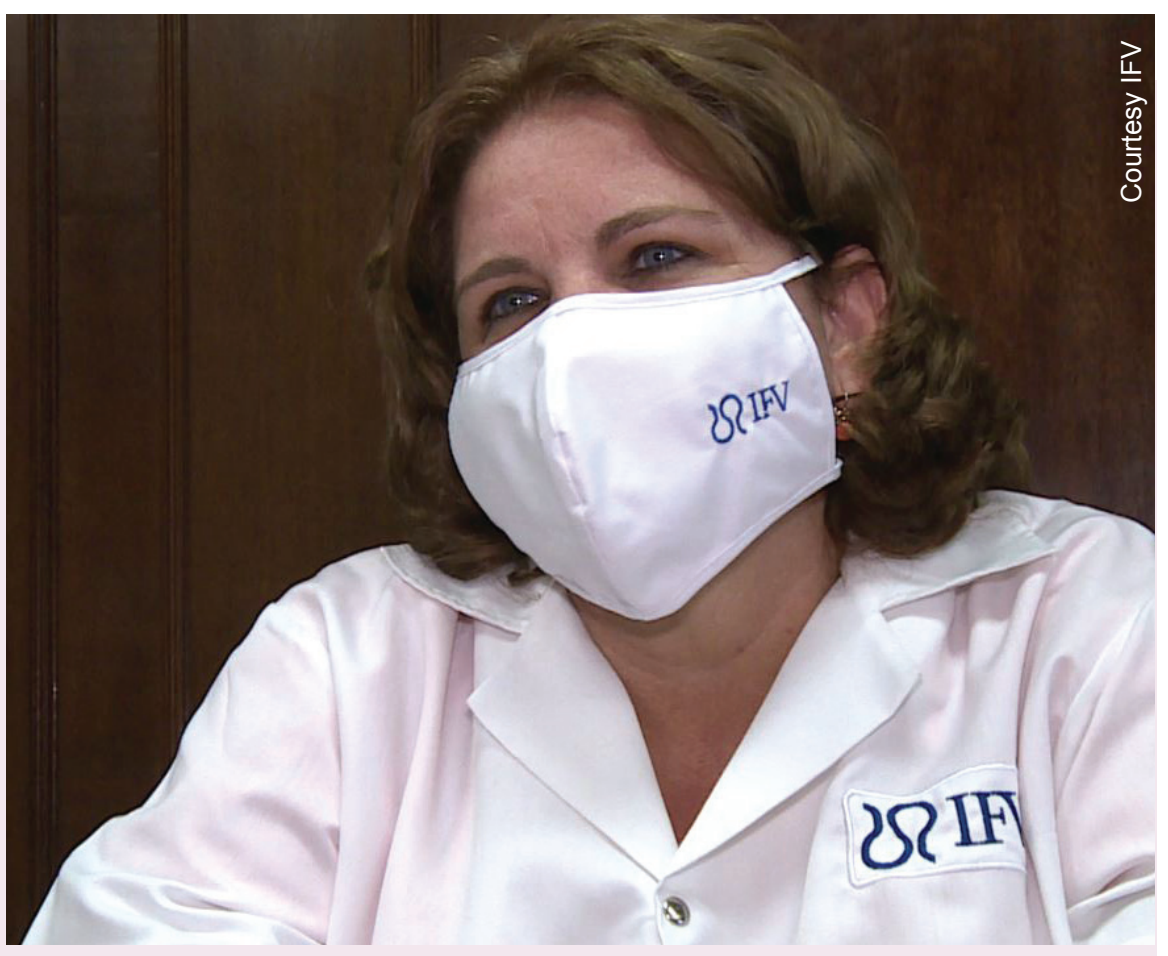
erate BioCubaFarma, has developed and distributed vaccines according to international standards of good clinical and manufacturing practices and protocols for decades. BioCubaFarma supplies over 800 products to Cuba's national health system-349 of those are on Cuba's Basic Drug List, the medicines approved for use in the country's health system. Additionally, BioCubaFarma has 2438 patents registered outside Cuba and its products, including vaccines, medicines and medical equipment, are in 100 simultaneous trials at 200 clinical sites and are registered and sold in more than 50 countries.

These factors proved advantageous for making a fast, confident pivot towards COVID-19 vaccine development. Specifically, these antecedents meant all necessary technical capacities and regulatory certifications were already in place. Founded in 1989, CECMED was certified as a WHO Level 4 Regulatory Authority of Reference for vaccine control (the highest certification level conferred) in 2017; also in 1989, a team at Cuba's Finlay Vaccine Institute led by Dr Concepción Campa, developed VA-MENGOC-BC, the world's first safe, effective vaccine against serogroup $B$ meningococcus; and in 2000, Cuba's recombinant hepatitis $B$ vaccine received WHOPAHO pre-qualification. To date, millions of people in Cuba and elsewhere have been immunized against a variety of diseases with vaccines from the island.

Shortly after COVID-19 was declared a pandemic by WHO, this expertise was marshaled to develop a Cuban vaccine

against the disease. Researchers from the Finlay Vaccine Institute (IFV), the Molecular Immunology Center (CIM) and the University of Havana's Chemical and Biomolecular Synthesis Laboratory, with support from other BioCubaFarma enterprises, are leading the project aimed at delivering a safe, effective vaccine in 2021.

The SOBERANA team, which is working on two vaccine candidates, SOBERANA 01 and SOBERANA 02 and several formulations thereof, is led by Dr Vicente Vérez-Bencomo, IFV Director, Dr Yury Valdés Balbín, IFV Deputy Director; and Dr Dagmar García Rivera, IFV's Director of Research, a post she has held since 2014. A vaccine expert with a PhD in pharmaceutical sciences, Dr García Rivera is recognized for her multiple contributions to Cuban science, including development of a pneumococcal conjugate vaccine that is concluding Phase III clinical trials in preparation for introduction into the country's national health system. She was awarded Cuba's Annual Health Prize, the national prize of the Cuban Academy of Sciences on three occasions, and in 2019, received the Carlos J Finlay Order of Merit. Dr Garcia Rivera has represented Cuba in meetings of WHO, UNICEF and other multilateral organizations. In late September, with safety and immunogenicity trials for SOBERANA 01 continuing apace, Dr Garcia Rivera paused her feverish work schedule for this exclusive interview with MEDICC Review. 
MEDICC Review: Cuba's first vaccine candidate, SOBERANA 01 , qualified for clinical trials rapidly-in just 90 days. Can you describe the research process?

Dagmar García: In January 2020, Cuba drafted its National COVID-19 Prevention \& Control Plan and convened an innovation committee to work on a vaccine. But since we're dealing with a novel coronavirus, there wasn't enough scientific evidence available at that time for us to determine what kind of candidate might be appropriate.

So our first challenge as researchers was to amass all the scientific evidence and analyze it. And analyze it again. And then reanalyze it, incorporating new studies and scientific information as it emerged. We had to understand the physiopathological mechanisms of the virus, as well as the nature of the protective immune response the virus induced in infected people.

We have a situation with the emergence of SARS-CoV-2 whereby the virus and its devastating consequences advanced faster than our knowledge base. Research conducted globally becomes enormously important in this context.

\section{MEDICC Review: And Cuban researchers had access to this research?}

Dagmar García: Scientific research and publishing took an unprecedented turn with COVID-19: journals worldwide provided open access to their publications, guaranteeing broad, timely access to the information needed to help control the epidemic. This allowed us to incorporate new knowledge about the virus, the disease and the relevance of potential antigens for vaccine candidates on a daily basis.

I think this open-access model for knowledgesharing should become

Access to scientific knowledge should not be limited

the norm. And we hope it does-access to scientific knowledge should not be limited.

MEDICC Review: Unprecedented also, is the adjustment of regulatory mechanisms to develop a vaccine as fast as possible. What implications does this have-for the vaccine itself and related bioethics protocols?

Dagmar García: We're in the midst of a global health emergency. Normally it takes an average of 10 years to develop a vaccine, but we don't have that luxury with COVID-19. So regulatory mechanisms have been reorganized to shorten the development cycle to produce a vaccine as quickly as possible. In fact, most national regulatory authorities (NRAs) in those countries with vaccine candidates in development or clinical trials have made their regulatory mechanisms more flexible, permitting overlap of different phases. But that does not mean violating the ethical research principles or the necessary steps to develop and register a vaccine once it has proven safe and effective.

Our clinical trials are designed and conducted according to the highest international standards and established best practices; a vaccine's target population is a healthy population, which explains why the vaccine industry is the world's most highly regulated. Transparency is mandatory. Cuba practices transparency and has shared all the necessary information throughout this vaccine development process. All our clinical trial protocols are published in the Cuban Public Registry of Clinical Trials (a WHO-accredited primary registry since 2011 and member of WHO International Clinical Trials Registry Platform, ICTRP; https://rpcec.sld.cu, Eds), a step required of all trials globally. And our national media regularly report to a broader public on the progress of SOBERANA 01.

Both our vaccine candidates, SOBERANA 01 and 02 have applied for patent registration with the Cuban Office of Industrial Property and our scientific results will be submitted to peer-reviewed journals once they're ready.

Cuba's biotechnology sector has been awarded 10 gold medals from the World Intellectual Property Organization (WIPO), including for the VA-MENGOC-BC vaccine developed by the Finlay Vaccine Institute (1989) and for Quimi-Hib developed by the University of Havana's Chemical and Biomolecular Synthesis Laboratory (2005).

MEDICC Review: Globally, over 40 vaccines have reached the stage of clinical trials in humans, using different technologies. What type of vaccine is SOBERANA 01?

Dagmar García: By March 2020, we began to see vaccine candidates that employed more traditional technologies-like those using inactive viruses to provoke a protective immune response. Given the urgency for a potential vaccine, certain processes were sped up allowing vaccine prototypes using newer technologies still in development to proceed to clinical phases. Adenoviral vector vaccine candidates and those using messenger RNA (mRNA) technology, for example, are among those not yet proven effective in humans.

But given our past experience, knowledge and success with other vaccines, we leaned towards a protein-subunit vaccine. The subunit vaccine platform is well established in Cuba. Importantly, VA-MENGOC-BC, IFV's meningitis $B$ vaccine, is a subunits vaccine developed over 30 years ago and is a key component in our SOBERANA vaccine candidates. We have other subunit vaccines in our portfolio, including a recombinant hepatitis $B$ vaccine and the Haemophilus influenzae type b (Hib) vaccine using a synthetic antigen, the first of its kind in the world (Hib vaccine development was headed by Dr Vicente Vérez-Bencomo; for more on his work and this vaccine, see MEDICC Review October 2007, Vol 9, No 1, Eds). The pentavalent vaccine used to vaccinate all Cuban children under one year old has subunit components (introduced in 2006, this Cuban-manufactured vaccine immunizes children against diphtheria, tetanus, pertussis, hepatitis B and Haemophilus influenzae type b, Eds).

MEDICC Review: Can you explain how the Cuban COVID-19 subunit vaccine candidate works and if it has inherent advantages?

Dagmar García: For this type of vaccine to be effective, its crucial to know which part of the virus subunit, which antigen, is most significant. This took us more time to figure out. But once it became clear that the most relevant antigen is the receptor- 


\section{Cuba's Women of Science}

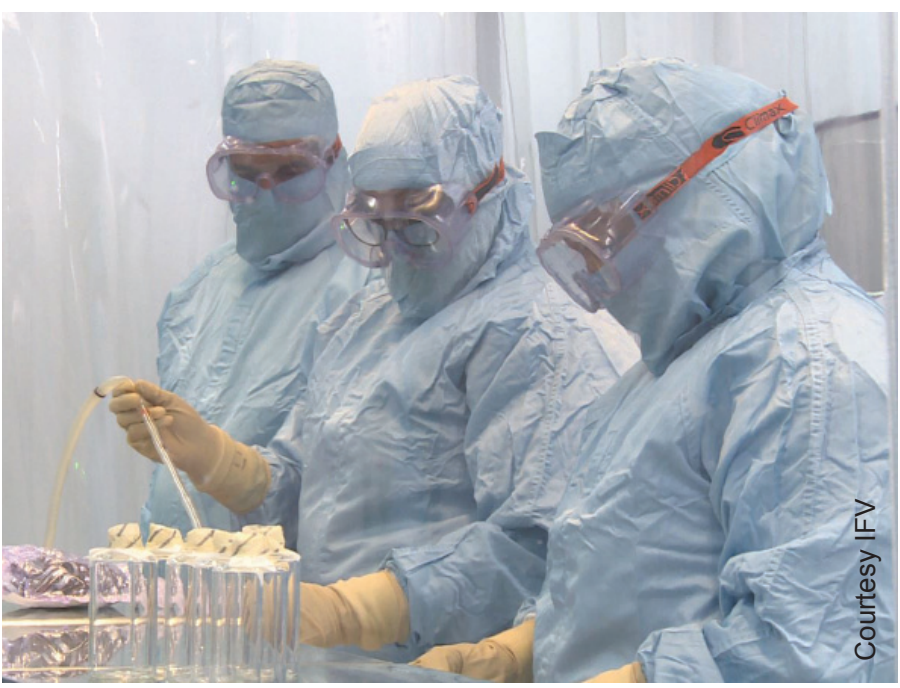

binding domain (RBD) of the viral Spike (S) glycoprotein-the protein that allows SARS-CoV-2 to invade human cells through the angiotensin-converting enzyme 2 or ACE2 receptor-this is where we focused our research. Using established genetic engineering methods and biotechnology processes, our colleagues at CIM successfully produced the RBD protein in mammalian cells. This gave us a well-defined and stable molecular structure with which to continue research.

Our first candidate, SOBERANA 01, is a two-dose vaccine based on an RBD amino-acid sequence that by design allows natural dimerization of two RBD molecules. This is combined with outer membrane vesicles of meningococcus $B$ that act as an immunopotentiator. In short, the goal is to induce production of neutralizing antibodies against SARS-CoV-2.

"The presence of receptor-binding domain (RBD) antibodies 7 days post-vaccination in animals-and even more, after 28 days-is likely attributable to the immuneresponse strengthening ability of the outer membrane vesicles in which we formulated the vaccine."

-Dr Dagmar García, Mesa Redonda prime time TV news program, Aug 20, 2020

There are several advantages to this approach. First, it uses an established technological platform proven over more than 30 years' experience-the platform used for our VA-MENGOC-BC vaccine. This translates into faster development and implies safety advantages for vaccine candidates. Second, we believe that a vaccine based on the RBD protein has high probabilities of success because immunological studies in patients recovering from COVID-19 show it's the most relevant viral component for inducing neutralizing antibodies.

Importantly, our biotechnology industry uses a model in which the scientific and technological capacities of each institution are coordinated, complementing one another. For example, for over 20 years, CIM has worked in large-scale production of complex recombinant proteins in mammalian cells and has mastered the necessary immunological techniques used in earlier development of their therapeutic cancer vaccines. The University of Havana's Chemical and Biomolecular Synthesis Laboratory, meanwhile, contributes molecular-level research. We work as a consortium, an alliance that has allowed us to make rapid progress towards a vaccine; none of our institutions could have developed a vaccine candidate this fast alone.

Finally, we know there will be COVID-19 vaccines available around the world. But for a country like Cuba, it's prudent and strategic to develop and manufacture our own vaccine. So for us a major advantage of SOBERANA 01 is that it's Cuban.

\section{MEDICC Review: Hence the name...}

Given our past
experience,
knowledge and
success with other
vaccines, we
leaned towards
a protein-subunit
vaccine

Dagmar García: Calling our first vaccine candidate "SOVEREIGN 01" wasn't the original idea. This was simply the short name we gave to the clinical trial for this candidate. But once it was announced, the Cuban public reacted so enthusiastically that we decided to honor their support by grouping all our vaccine candidates under the name SOBERANA. The candidate now in Phase I/II trials is SOBERANA 01; our second candidate - also based on the RBD protein but using a different platform - will begin trials soon, is SOBERANA 02, and so on. We hope both of these candidates, in one of their formulations, will demonstrate clinical efficacy.

\section{MEDICC Review: What does the clinical trial process for SOBERANA 01 entail? How are trials conducted and by whom?}

Dagmar García: The first step was receiving authorization for the trials from CECMED, Cuba's national regulatory agency. This requires submitting a dossier that contains detailed information related to the product's development and preclinical research: the chemical-pharmaceutical components, quality criteria, pharmacology and toxicology analyses in animal experiments, and protocols for clinical evaluation, among others. Once authorized, trial protocols and details must be published in the Cuban Public Registry of Clinical Trials. All clinical trials in Cuba require approval from the pertinent Independent Ethics Committee for Scientific Research before they can move forward-in this case, the National Toxicology Center (CENATOX).

The SOBERANA 01 clinical trials are administered by CENATOX. In 2009, this institute was certified according to best clinical practices by CECMED to conduct clinical trials, undergoes regular inspections by international agencies and has successfully conducted clinical trials with other biotechnology products. The design protocol calls for two doses, administered 28 days apart to healthy volunteers, including a randomized control group, which receives the VA-MENGOC-BC vaccine. It's hoped that the reactogenicity in both cohorts will be similar.

Inclusion criteria for the trial are strictly defined. Potential volunteers receive comprehensive information-written and ver- 
bally-about what the trial entails and a description of how it will proceed so they can decide whether to participate. This includes the risks and benefits involved, the most common adverse events and what to do should such an event occur; we also explain to volunteers that conditions are guaranteed to treat adverse events and that they are free to leave the trial at any time.

Each person who decides to participate gives written informed consent. We then conduct comprehensive clinical studies, administer RT-PCR tests, and analyze other inclusion criteria like body mass index. Those testing positive for SARS-CoV-2 antibodies are not eligible to participate. Clinical evaluations occur 24, 48 and 72 hours after the first and second injections, followed by similar evaluations 14, 21 and 30 days after each injection. Followup with volunteers continues for two months and adheres strictly to the protocols established in our clinical trial design.

The trials are being conducted at certified clinical sites in Havanawe have extensive experience conducting trials with other vaccine candidates in other provinces, but due to epidemiological constraints and other logistical considerations, these phases are being conducted in the capital only. The 19-59 year old cohort received their first doses on August 24 . Once preliminary safety of the vaccine was demonstrated with them, the second cohort, ages 60-80, received their first doses on September 11.

MEDICC Review: Inclusion criteria were for healthy adults from 19 to 80 years old, among others. Did you have challenges recruiting volunteers?

Dagmar García: The biggest challenge we faced recruiting volunteers is that we were inundated with requests. Too many people wanted to participate and we had to explain that this was a smallscale trial and that there would be more opportunities to volunteer in the future with this vaccine candidate or others. This includes the possibility of trials in other provinces, not just Havana. (Cuba's National Clinical Trials Site Network coordinates extension of trials to certified sites throughout the health system. For details see The ABCs of Clinical Trials in Cuba, MEDICC Review, July 2016, Vol 18, No 3, Eds).

There is public trust in these national programs, our vaccines and the science behind them.

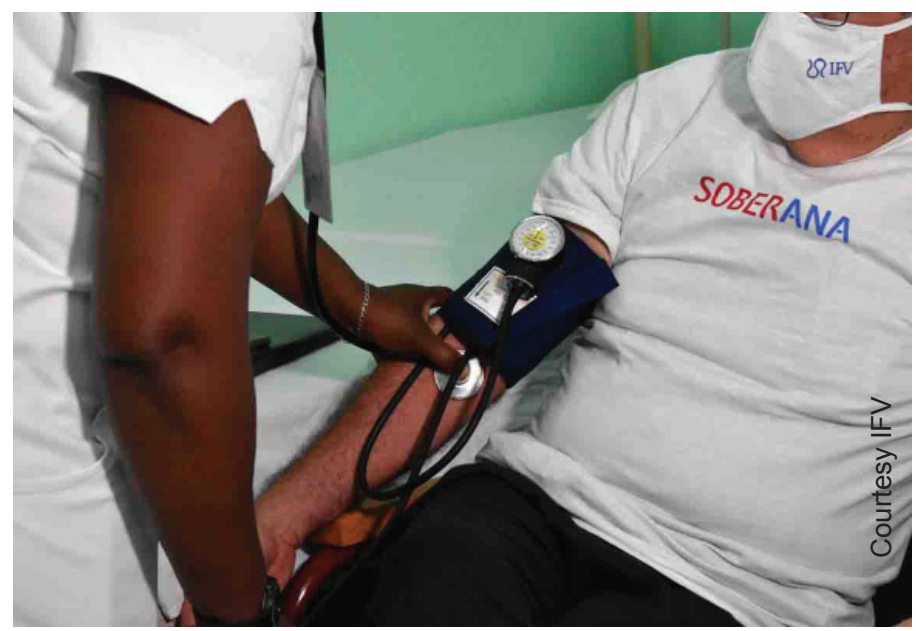

This overwhelming response is partly due to the urgency for a COVID-19 vaccine, but also because there is public trust in these national programs, our vaccines and the science behind them. Cuba established its National Immunization Program in 1962 and has very high rates of coverage. This 'culture of health,' coupled with a transparent process, means trial volunteers are making quite a conscious decision to participate in trials.

MEDICC Review: Are there special considerations or precautions taken with the cohort of older adults-a vulnerable group, especially with regards to COVID-19_during the trials?

Dagmar García: The inclusion criteria and protocols for the older cohort are the same as those aged 19 to 59 . However, to be eligible, those volunteers with chronic conditions had to demonstrate that they were clinically controlled. In addition to the periodic exams of every participant that I described, everyone also received a card that identifies them as a participant in the SOBERANA 01 clinical trial. And our entire health system is on alert. Should a volunteer become ill or have any health issue during the trial, including the two-month follow up period, they show this ID card to anyone at a health institution. This allows procedures to be implemented that are designed specifically for participants in this clinical trial. Furthermore, should a participant receive a positive RT-PCR test during the clinical trial, our national protocols for COVID-19 treatment are immediately activated and that person is removed from the trial.

\section{MEDICC Review: Can you share initial results of the SOBER- ANA 01 trials?}

Dagmar García: Our initial safety results are satisfactory, with no severe adverse events. For the next two months, we'll be gathering immunogenicity data to analyze which formulations, using different antigen levels, will proceed to future trials. Everyone is anxious for information and a successful vaccine, but at this point the clinical process is very slow and we can't speed it up. Two months are two months.

Looking forward, we have to demonstrate safety, immunogenicity and efficacy of whichever formulation of SOBERANA 01 (or another of our vaccine candidates) proceeds to the next phases of clinical trials. This is true for our vaccine candidates, as well as those in clinical trials around the world. Not enough time has elapsed to determine what level of immunity one of these candidates will confer or how long it will last-obviously this is incredibly important for any vaccine, including ours, and we will have to demonstrate this as well.

\section{MEDICC Review: Will Phase III trials be conducted in Cuba?}

Dagmar García: Phase III clinical trials involve thousands of people and while Cuba has a very willing population, anxious to

Phase II objective: Increased immune response (seroconversion of antibody titers equal to or greater than 4 times the initial baseline) in at least $50 \%$ of subjects compared to control group.

-Objectives and Variables, SOBERANA 01, Cuban Public Registry of Clinical Trials 
volunteer, we probably don't have the necessary COVID-19 incidence rate in our country to conduct trials of this scale.

While it is still too early to define where, when and how we would conduct these trials since this depends on the evolution of current clinical research, I can say unequivocally that if we need to go to another country to conduct Phase III trials, we will. Cuba has options for where that might be and all regulatory requirements of that country or those countries will be met to conduct those trials-with SOBERANA 01 or any other vaccine candidate.

MEDICC Review: One consideration around the world is production capacity for a COVID-19 vaccine. Assuming one of the SOBERANA candidates is approved for use, do you anticipate problems producing the doses needed?
We're deeply motivated by science: we maintain our spirits imagining months of hard work paying off with a successful vaccine.

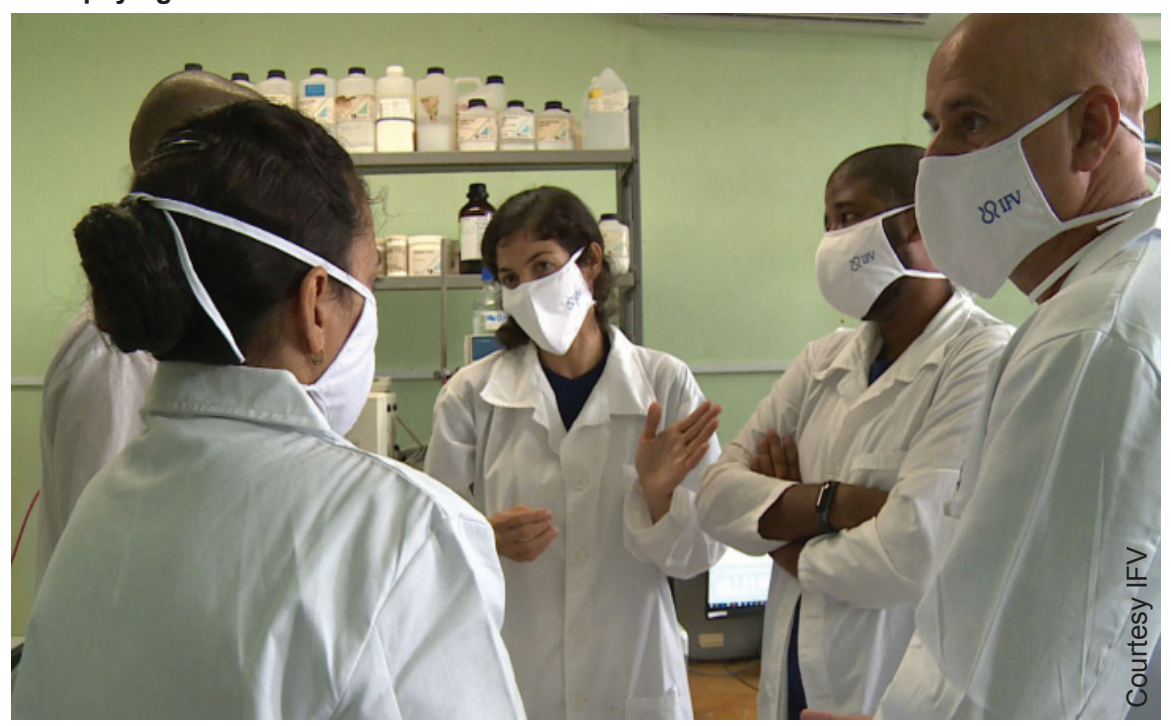

Dagmar García: Our first challenge will be to produce enough doses of a safe, effective vaccine to satisfy domestic demand. Cuba is a small country of just over 11 million people, so we're not talking about huge demand, but this does mean producing several million doses so that we can vaccinate our entire population.

\begin{tabular}{|l} 
IFV and CIM are ready to \\
start producing the number \\
of doses needed for our \\
population in existing, \\
certified manufacturing plants \\
conforming to international \\
standards
\end{tabular}

On the plus side, IFV's vaccine candidates are based on technology and platforms that our consortium uses to produce other vaccines. This means we don't have to construct production plants or train professionals. IFV and CIM are ready to start producing the number of doses needed for our population in existing, certified manufacturing plants conforming to international standards. Obviously, we will have to invest in upgrades and scale up production in some cases, but our capacity is already established and functioning.

Cuba also markets its biotech products, including vaccines, to dozens of countries. Once a SOBERANA vaccine becomes available for our population and then for sale abroad, these countries with which we already have contracts will logically be first in line.

\section{MEDICC Review: What about the ingredients needed to pro- duce the necessary doses? Does Cuba have them?}

Dagmar García: We don't have in Cuba all the raw materials and supplies we'll need for the unprecedented scale of production that vaccinating our whole population requires. They have to be purchased and for this, we need financing. This is made infinitely more difficult by the US embargo-which as you know is an economic and financial embargo, hence we call it a blockade. It affects development of every economic and social sector in Cuba, including vaccines. Procuring the necessary reagents for research and the raw materials for production is a challenge we face daily due to limitations imposed by the embargo.

MEDICC Review: Once a Cuban vaccine is available, how will it be introduced into the health system? Will certain groups be prioritized?

Dagmar García: We'll be able to produce enough of the vaccine for our whole population. How will that be implemented and what groups will be prioritized? I can't give a precise answer because it's not an industry decision. But I can tell you that it will be a national strategy developed together with the Ministry of Public Health (MINSAP) based on the clinical data and number of doses available. Most likely, certain high-risk groups will be considered first....but that has yet to be decided.

MEDICC Review: The stress and urgency of your work, combined with the US sanctions and difficulties in Cuba, must be enormous. How do you and your team handle this?

Dagmar García: For months, we've faced the same problems created by the pandemic as everyone else in Cuba: the limitations, our kids at home instead of at school, our families in lockdown. We haven't rested since the vaccine development process started months ago. We've had no vacations. But we're deeply motivated by science: we maintain our spirits imagining months of hard work paying off with a successful vaccine. It's gratifying to imagine our work saving lives and benefiting our country.

I think this is the fundamental motivation for everyone working on our COVID-19 vaccine. You see it in people working overtime, making sure they make their deadlines, working weekends. But no one complains. Everyone is in good spirits and knows that results achieved today will be important for decisions taken tomorrow, so we just can't fall behind. The good will and optimism is real and runs deep.

A distinctive characteristic of Cuban science is that there are more women in the scientific sector than men and this is true for the SOBERANA 01 project as well. It helps that there are many young people on our team, too. This injects a vibrant spirit into our work. 
Everyone is pulling together so that we can deliver a successful vaccine as soon as possible. Our families are a tremendous help in this regard: husbands, partners or other family members of many of the women working on SOBERANA, including mine, are at home as we speak taking care of the kids, cooking and cleaning. It would be very difficult for us to dedicate ourselves fully to this project otherwise.

MEDICC Review: Can you talk about the importance of international collaboration in confronting this pandemic? Will Cuba participate in the global COVAX initiative?

Dagmar García: This is the moment for international solidarity. No country can go it alone; a solution to this pandemic is only possible if it's contained the world over. I would add that the 'vaccine nationalism' we're seeing with COVID-19 is a direct result
We are going to see differences in vaccine access on a global scale over the next year of globalization. Every time a new disease emerges, the gap between rich and poor countries is underscored. The difference with COVID-19, as opposed to Ebola for instance, is that this disease affects rich and poor countries alike-but access to an effective vaccine will not be equitable. In spite of WHO efforts, we are going to see differences in vaccine access on a global scale over the next year.

In terms of COVAX (COVID-19 Vaccines Global Access Facility), we're assessing the possibility of Cuban participation. We've been in talks with the Coalition for Epidemic Preparedness Innovations (CEPI, a co-leader with WHO and GAVI in the COVAX initiative to accelerate development, production and equitable access to a vaccine, Eds.), but we will have to wait for results.
MEDICC Review: Looking ahead, what other Cuban research related to COVID-19 looks promising and what comes next for the SOBERANA project?

Dagmar García: Research is well under way by other Cuban scientists to determine whether genetics play a role in people's probability of developing severe cases of COVID-19 and if so, how. This research, led by the National Medical Genetics Center, includes people living with others infected by COVID-19 but who themselves have not become infected.

The National Blood Donors Group and the Hematology and Immunology Institute are co-leading a clinical research project involving use of blood plasma from patients recovering from COVID-19 used in therapies for those who have the disease. Of course, this research adheres to established clinical research protocols. This is just to mention a few of the projects under way for COVID-19 diagnosis and treatment.

As for our vaccine candidates, the balance of this year is dedicated to clinical trials of SOBERANA 01 and 02. Before the year is over, we will publish our pre-clinical trial results, and expect to publish the clinical trial results in early 2021. And while I can't pin down an exact date for when a vaccine will be ready, I can tell you two things: the first Cuban COVID-19 vaccine that is registered will be called SOBERANA and it will be ready to vaccinate our entire population sometime in the first six months of 2021.

\section{ACKNOWLEDGMENTS}

I am grateful for contributions by MEDICC Review's editorial team that made this interview possible. 1 - 


\title{
Early Action, Applied Research \& Collaboration to Combat COVID-19: María Guadalupe Guzmán MD PhD DSC
}

\section{Director, Reference Center for Research \& Diagnosis, Pedro Kourí Tropical Medicine}

\author{
Institute, Havana
}

\section{Gisele Coutin MD MS and Conner Gorry MA}

Virologist Dr María Guadalupe Guzmán is recognized as a global leader in dengue research and heads the Pedro Kourí Tropical Medicine Institute's work as a WHO/PAHO Collaborating Center for the Study of Dengue and Its Vector. The Institute (IPK) was founded in 1937 and is now Cuba's national reference center for the diagnosis, treatment, control and prevention of communicable diseases. Dr Guzmán is also president of the Cuban Society of Microbiology and Parasitology and directs IPK's Scientific Council, which is responsible for setting the Institute's research priorities. A recent h-index analysis found that Dr Guzmán is among the most widelypublished and cited Cuban researchers.

As part of the National Intersectoral Commission for COVID-19, IPK was integral to the design of Cuba's COVID-19 Prevention and Control Plan, approved in February 2020, more than a month before the first cases were confirmed in Cuba. This included the three-tiered biosafety training program for frontline health professionals, designed and launched at IPK, which built on the institution's experience preparing Cuban doctors who served in West Africa with the Henry Reeve Emergency Medical Contingent during the 2014-2016 Ebola outbreak. As of this writing, the Contingent has served in 39 countries fighting COVID-19. Prior to departure, members were trained in biosafety at IPK.

Today, IPK conducts COVID-19 testing and research and provides patient care. The institution is supported by an integrated national network of diagnostic laboratories, hospitals and isolation centers. In addition to research related to the clini-

\begin{abstract}
MEDICC Review: Latin America has become an epicenter of the COVID-19 pandemic, with some of the highest per capita infection rates in the world. Yet Cuba and Uruguay stand out as examples of containment, with lower rates. What might Cuba's experience offer in this context?
\end{abstract}

María Guadalupe Guzmán: The situation in the region is indeed complex, with an alarming rise in confirmed cases and COVID-19 fatalities - according to WHO data as of July 5, Latin America had registered over 5.5 million cases. Cuba took early action with a national plan aimed at controlling SARS-CoV-2 transmission and cal evolution and epidemiology of COVID-19, IPK has several studies under way on its diagnosis, pathogenesis, kinetics, immunity and genetics. In July 2020, Dr Guzmán, along with 7 other Cuban specialists, was appointed to the InterAcademy Partnership's (IAP) COVID-19 Expert Group, a 60-member, multi-disciplinary group comprised of researchers from around the world. The group is designed to promote knowledge sharing and regional and international collaborations concerning the coronavirus using a multisector approach that takes into account the health, social and environmental factors related to the disease. This MEDICC Review interview took place in early July, a few days before the Cuban IAP appointments were announced. 
contact with confirmed cases in isolation centers equipped for this purpose; and active screening across the country, including in workplaces and among high-risk groups.

I think Cuba's COVID-19 experience can be useful in the following areas: clinical case management; epidemiological measures designed to identify hot spots and better contain and control transmission; treatment protocols and products developed and produced by Cuba's biotech sector; laboratory diagnostics; and international collaboration-our specialists are serving in many countries where COVID-19 has created complex health situations.

MEDICC Review: Research is indicating that SARS-CoV-2 is much more contagious than other human coronaviruses including SARS-CoV and MERS-CoV. How is this indicator playing out in Cuba?

María Guadalupe Guzmán: This virus's highly contagious nature is one reason why COVID-19 has spread so far, so fast and to so many countries. Several articles have described that each infected person can transmit the virus to three more people. Slowing transmission requires lowering the disease's reproduction number ( $\mathrm{R}$-value).

Since the first cases in Cuba, scientists here have been working on transmission forecasts using mathematical models based on time-varying reproduction numbers ( $R_{t}$; effective reproduction). As opposed to $R_{0}$, which is the basic reproduction number quantifying a disease's transmission potential at the start of an epidemic, $R_{t}$ numbers change over time and depend on the population's actual susceptibility to the disease. At the beginning of the epidemic, we were seeing high $R_{t}$ numbers - near 5 , which is consistent with the exponential transmission dynamic seen in other countries. After 15 days, that number steadily dropped to just above 1 and by the seventh week, it fell below the $R_{t} 1$ target. This indicator has fluctuated with periodic local transmission events, but once prevention and control measures contain the outbreak, the $R_{t}$ number falls below 1 again-underscoring the importance of maintaining these measures to slow transmission.

MEDICC Review: Given how contagious SARS-CoV-2 has proven to be, how is Cuba managing testing, contact tracing and treatment?

María Guadalupe Guzmán: One fundamental action we've taken is administering and analyzing a large number of tests to identify both symptomatic and asymptomatic cases. (According to the website of Cuba's Ministry of Public Health, between August 17 and September 17, Cuba was processing an average of 6010 RT-PCR tests daily and at the time of this writing had performed 524,374 tests since March, Eds). This allows for early diagnosis, tracing of all available contacts for each confirmed case and remittance to isolation centers.

Applied research from Cuba's biotech sector is another important element. Adding Cuban biotech products to treatment protocols; sample collection; implementing case management policies; and assuring we have the necessary equipment and materials for treating critical patients by switching production lines at some plants to produce personal protective equipment, ventilators and diagnostic kits, are some ways our biotech sector is helping us confront the epidemic.

MEDICC Review: You mentioned that Cuba performs RT-PCR tests-several thousand a day. Where do these come from and where are they processed? Are labs in Cuba equipped and prepared for this kind of diagnostic load?

María Guadalupe Guzmán: At the moment our RT-PCR tests are imported, though the Immunoassay Center in Havana (CIE) is working on standardizing a molecular diagnostic kit and several population studies are already underway using the CIE'S system for detecting COVID-19 antibodies.

In terms of laboratories diagnosing COVID-19, we currently have 7. Those processing tests for Havana are located at the Provincial Hygiene, Epidemiology and Microbiology Center and the Hermanos Ameijeiras Clinical-Surgical Teaching Hospital, plus the Genetic Engineering and Biotechnology Center (CIGB) and Civil Defense laboratories. The laboratory here at IPK processes tests for the capital, plus the western region of the country, while the Ministry of Public Health's lab in Villa Clara handles testing from Cuba's central region and the one in Santiago de Cuba processes those from the eastern region. Four additional labs are currently being equipped in the provinces for processing tests as well and should be up and running soon. (Two labs, in Holguín and Matanzas provinces, will be operable by the end of September, and the other two, in Ciego de Ávila province and the Isle of Youth, soon thereafter. Since this interview, Havana has added five more labs to process RT-PCR tests, Eds). IPK is charged with evaluating these labs, plus training and assessing the personnel working there.

In addition to training lab personnel to process these tests, IPK evaluates the kits and technologies used in coronavirus diagnosis, as well as the transportation mechanisms used to collect patient samples, the equipment introduced to strengthen case diagnosis, and serological systems used for patient screening. IPK is also responsible for periodic quality control of samples to corroborate results from other laboratories around the country.

\section{MEDICC Review: Was this all put into place with the advent of COVID-19?}

María Guadalupe Guzmán: No. As a WHO/PAHO Collaborating Center for the Study of Dengue and Its Vector, IPK has a long, strong work history related to the clinical, epidemiological, laboratory, training, entomology-vectors and research components concerning arboviruses. Our collaborating center works on these issues as part of the PAHO-led Integrated Management Strategy for Arboviral Diseases and helped draft several guidelines used regionally today. These include clinical case management for dengue; diagnosis and treatment of patients with possible arbovirus infections; and diagnostic algorithms for laboratory surveillance of dengue, Zika and chikungunya.

In 2008, the Arbovirus Diagnosis Laboratory Network of the Americas (RELDA) was established to strengthen laboratory diagnostic and surveillance capabilities in the region (The WHO/ 
PAHO Coordinating Center at IPK headed RELDA from 20102018, with Dr Guzmán as president, Eds). It's also designed to systematize best practices and foster collaboration among labs in the region. To this end, RELDA holds training courses in new diagnostic technologies, develops protocols and guidelines, coordinates the exchange of reagents between labs, performs serological and molecular proficiency testing to verify the reliability of laboratory diagnostics, standardizes diagnostic systems and more. Today, 32 laboratories in 26 countries are part of this network-many are also WHO/PAHO Collaborating Centers.

\section{It's crucial that countries
devise strategies for dealing
with coexisting dengue and
cOvID-19 epidemics}

The work creating and strengthening these labs, their infrastructure and training capacities, plus our regional experience with the 2009 flu pandemic, means we were better prepared and equipped to pivot from arboviruses to COVID-19. RELDA and the labs in its network have worked diligently to face this emergency-and laboratory diagnosis of COVID-19 has proven challenging for all countrieswithout slowing the diagnosis and surveillance of arboviruses. In fact, we're expecting an increase in dengue transmission this year and RELDA has been discussing how to manage both at once. It's crucial that countries devise strategies for dealing with coexisting dengue and COVID-19 epidemics; controlling dengue-related deaths while maintaining measures implemented in recent years to lower dengue fatalities in the midst of COVID-19...it's quite a complex situation.

MEDICC Review: SARS-CoV-2 has shown to be highly lethal, with a $13 \%$ patient fatality rate in some countries and around $6 \%$ in Latin America. How has Cuba, with its aging population and heavy chronic disease burden-not to mention the US embargo-been able to keep its rate well below $5 \%$ ?

María Guadalupe Guzmán: I think early action is one of the main factors. Active screening in neighborhoods everywhere in the country, along with hospitalization of all suspected cases and timely attention to them-in health institutions with separate areas specially equipped and staffed-has helped us keep fatality rates here below $5 \%$. Application of different treatment protocols, which are showing good results, is another factor. Our health messaging strategy, alerting and keeping the population informed, and their collaboration in active screening is one more. Staying informed about COVID-19 and continuing to observe health measures, including using masks, is imperative.

It's important to underscore the role of our primary care system in this regard. Primary care professionals here are communitybased, have direct contact with the people they serve in the neighborhoods where they live, and are actively looking for and diagnosing cases.

MEDICC Review: Cuba's biotech products and treatment protocols are showing good results, as you mentioned. As part of the team that sets IPK's research priorities, what is the Institute's research agenda for COVID-19?
María Guadalupe Guzmán: IPK is pursuing several research initiatives, including in the following areas:

- COVID-19 etiology;

- Morphology of SARS-CoV-2 (in collaboration with CEAC);

- Nucleotide sequence (whole genome) and molecular characterization;

- Viral shedding kinetics in clinical samples; Ultrastructural tissue damage, identifying immunological biomarkers associated with severe clinical prognosis, immune system response associated with protection/severity, and genetic and epigenetic influences on the progression of the infection (in collaboration with $\mathrm{CEAC)}$;

- Evaluation of reagents, materials and equipment (in collaboration with the National Biopreparations Center, BIOCEN, as well as MEDICUBA and the National Biomedical Engineering Center);

- Evaluation of serologic diagnostic kits and PCR tests (in collaboration with the Immunoassay Center; CIE);

- Development of a biosensor to diagnose COVID-19 in cooperation with the Cuban Center for Advanced Studies (CEAC);

- Epidemiological studies of asymptomatic infections, outbreaks themselves, and socioeconomic factors related to the disease; and

- Clinical characterization of critical and non-critical patients, and clinical follow-up of symptomatic and asymptomatic patients.

Several of these research avenues are already showing results. We've characterized the clinical features of the first COVID-19 patients in Cuba, identified the immunological biomarkers for disease severity, and have a deeper understanding of those patients and asymptomatic carriers who maintain positive RT-PCR tests over time. We've also evaluated serologic diagnostic kits, including those produced in Cuba using UMELISA technology, currently in use in screening studies.

MEDICC Review: Cuba is known globally for its overseas medical cooperation, while IPK is known for its biennial International Course on Dengue, Zika and Other Emerging Arboviruses. How important is cooperation-locally, regionally, internationally-in fighting COVID-19?

María Guadalupe Guzmán: The role of international organizations like PAHO and WHO cannot be overstated. From best practices and recommendations for confronting the epidemic to donations of reagents and materials, their collaboration has been fundamental. Other organizations including the Global Fund and MediCuba Europe have also provided necessary support.

Also important is participation in thematic networks to exchange ideas, such as those organized by the Community of Latin 
American and Caribbean States (CELAC), the International Association of National Public Health Institutes (IANPHI) and the Ibero-American Science and Technology for Development Program (CYTED).

I also see a broad range
of opportunities for
collaboration between Cuba
and the United States

I also see a broad range of opportunities for collaboration between Cuba and the United States. Exchanging findings on each country's COVID-19 policies and lessons learned-what has worked and what hasn't-is one place to start. Sharing clinical case experiences and the use of different treatment protocols is another. Joint research to develop a better diagnostic kit or vaccine, to deepen our understanding of the disease and its viral agent or effective prevention measures...these are all potential areas for collaboration, as is joint publishing on findings. Even global medical cooperation, in which Cuba has vast experience, could be on the table.

For more on the research, clinical practices and diagnostic systems of the Pedro Kourí Tropical Medicine Institute (IPK), see Cuba's Pedro Kourí Tropical Medicine Institute: Battling COVID-19 One Study, One Test, One Patient at a Time, in MEDICC Review April 2020, Vol 22, No 2. - 1 


\title{
A PAHO Perspective on COVID-19 in Cuba José Moya MD MPH PhD
} PAHO/WHO Permanent Representative in Cuba

\author{
Gail A. Reed MS
}

If all physicians are detectives, using their skills to track down what ails body and mind, then epidemiologists are medicine's social detectives, using their training to understand the great calamities of population health. For over 30 years, Dr José Moya has worked in the field since his initial position as head of epidemiology in Ayacucho, in his home country of Peru. His journey into global health began with Doctors Without Borders in Guatemala, Mozambique and Nigeria. Later at $\mathrm{PAHO}$, he was Permanent Representative in Venezuela, after earlier postings as an epidemiologist in Haiti, Mexico, Brazil, the Dominican Republic and Argentina.

Dr Moya has faced down epidemics of malaria, dengue, yellow fever and bubonic plague, and also rampant chronic diseases such as hypertension and diabetes. Yet undoubtedly he has seen nothing like

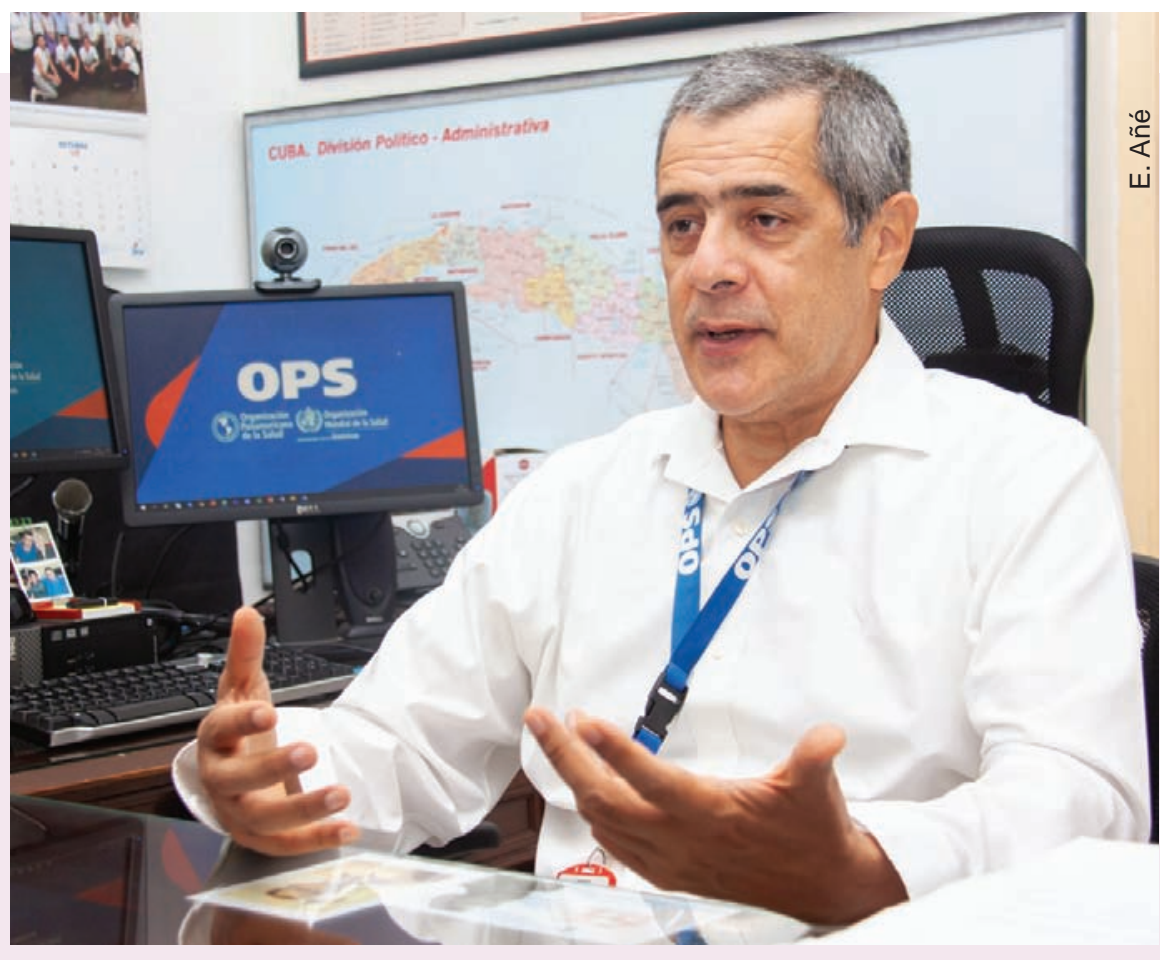
COVID-19 in the Americas, where at this writing 17 million cases have ravaged Latin America and the United States is the pandemic's epicenter in the hemisphere and the world. In 2019, Dr Moya became PAHO/WHO Permanent Representative in Cuba, shortly before COVID-19

presented itself. Eight months later, as most of Cuba began its "new normal" phase with new cases waning, MEDICC Review spoke with the epidemiologist about conditions on the ground and Cuba's response to COVID-19.
MEDICC Review: Cuba has recorded just over 6000 COVID-19 cases since March and fewer than 150 deaths. With the exception of positive results in Uruguay, the rest of Latin America is still faced with an alarming spread. Are there strategies adopted by countries like Cuba that help explain such different results?

José Moya: Up to now, Cuba has done everything a country should do in the face of a pandemic like this one, building on the strengths it already had. These include the health system itself, which is a single, universal system with national coverage and free-of-charge to patients. Family doctors and nurses are posted in communities across the country-professionals who know their communities and work with local people on a permanent basis.

Such primary health care is an enormous strength of Cuba's system: family doctor-and-nurse offices and community-based polyclinics carry out the main health programs and play a key role in the successes of Cuban public health. Another strength is the workforce's magnitude and training: the physicians, nurses, laboratory technicians and so on. And a third strength is science itself. Cuba's experience in research, with the institutions that today make up BioCubaFarma, dates back over 30 years. These are very serious research centers with first-class scientists organized for innovation. As a result, Cuba has developed domestic production capabilities in such areas as COVID-19 diagnostics, personal protection equipment (PPE) for the country's health workers and novel medications in clinical trials. They are also producing medicines for prevention that strengthen the immune system, particularly important for vulnerable people such as older adults and health workers.

So these three strengths-primary health care, human resources for health and development of science and technology-are the basis for a better response to the pandemic. Thus, when COVID-19 was on the horizon, they were able to take quick and timely action. By the end of January, Cuba had put together a national multi-sector plan, which is continually updated. Very early, they also had a protocol for treatment. This has meant almost daily sessions of the cabinet and of the various sectors, in order to monitor the COVID-19 response and its results, based on good epidemiological surveillance capacities through the health system's extensive epidemiological and laboratory networks already in existence. 
Cuba started with 3 labs for COVID-19 testing, and now has 13, so nearly every province has one, enabling the country to upgrade capacities for RT-PCR testing from some 2000 tests daily in March to 7000-8000 daily now.

We've seen an excellent response in terms of active screening for cases, confirmatory laboratory testing, contact tracing and follow-up. This enabled control of the epidemic's evolution, as we saw in June and July. Later, in August and September, we saw an uptick in cases-much like that in other countries as they began to re-open-punctuated unfortunately by some people failing to abide by the safety measures adopted. Now, once again, we have many provinces without transmission for several weeks, entering what's called the "new normal" period. Just three provinces, including Havana, still have some of the most restrictive measures in place.

At this new juncture, the message is loud and clear: the burden falls on every one of us here in Cuba to help tame the epidemic, by continuing to wear masks, practice social distancing, wash hands, disinfect surfaces and avoid big gatherings. We need to do our part so that in the next few months, although we have transmission, it will be controlled and not get out of hand. This means internalizing new habits in our daily lives.

Cuba has also moved to quickly identify cases and apply treatment protocols, using their own medications as well as others, thus reducing case fatality. In April, this was over $4 \%$, and now it is under $2 \%$.

These are some of the elements contributing to more favorable results, starting from a solid health system foundation and a unified national response plan, implemented throughout the national, provincial and municipal levels. This marks the difference from some other countries in our region that are suffering intense and sustained transmission due to overcrowded health facilities, population density in our megacities, and a concentration of poverty and social inequalities exacerbated by the pandemic, among other factors. Our health services haven't been able to confront this situation in time, and some have even collapsed. This is the lamentable reality we see in Latin America.

MEDICC Review: I want to ask you about two aspects of Cuba's response that may seem unrelated: the first concerns to what degree Cubans feel confident in their health system, and the second relates to the health system's decision to hospitalize all confirmed cases instead of sending them home...something not common elsewhere.

José Moya: The confidence Cubans have in their health system is palpable wherever you go here. They're aware of the capabilities of their health professionals, of health services, to attend to and resolve their health problems, from the simple to the most complex. Not only at the primary care level, but also at very highlevel hospital and research institutions, teaching centers where the most highly trained specialists are concentrated.

And this goes to the second part of your question: I don't think another country has hospitalized all patients diagnosed with COVID-19. Every person confirmed with COVID-19 is hospitalized in one of 30 hospitals specially equipped throughout Cuba to provide care to these patients, including ICU beds. It's worth mentioning that in April, when we saw the highest transmission rates, just $20 \%$ of ICU beds were occupied.

Another key decision was contact tracing for all confirmed cases, referring many people to isolation centers, where they were tested and under medical observation for 14 days. This strategy has brought the epidemic under control at different points, the first in June-July as I mentioned, and also in the last few weeks with the decrease in cases.

Now, in the "new normal" period, they will continue active case finding and contact tracing, but contacts are able to self-quarantine at home for the required period, under medical supervision and visited by their neighborhood family doctor. This is an important change, and once again, its success depends on all of us: our ability to self-quarantine when necessary, acting responsibly as individuals and communities during Cuba's re-opening. It's the only way forward until there is a vaccine.

\section{MEDICC Review: This period envisions opening schools and universities, correct?}

José Moya: Yes, although in Havana this won't happen until November 2. This process is accompanied by clear protocols, ones we've already seen on television being applied in several other provinces where the educational institutions are already up and running again. Children go to school with their masks on and in the first few days, receive an orientation and training on how they need to behave. This doesn't come as a surprise to them of course: most have been watching the daily briefings by $\mathrm{Dr}$ Francisco Durán, the country's chief epidemiologist. In general, I'd say that I've observed children acting quite responsibly. This responsibility - to mask up, wash their hands, not attend class if they have any symptoms-of course also implies a greater responsibility on the part of their parents and the schools themselves.

MEDICC Review: You referred to the biotech sector's 30 years of experience. Cuba now has a vaccine candidate for COVID-19 in clinical trials. What does the regulatory framework look like? Does PAHO or WHO have a relationship that allows these agencies to evaluate the regulatory process?

The Center for State Control of
Medicines and Medical Devices
(CECMED), Cuba's regulatory
agency, has
top-notch capabilities

José Moya: The Center for State Control of Medicines and Medical Devices (CECMED), Cuba's regulatory agency, has top-notch capabilities and because of this, is a regional reference and $\mathrm{PAHO} / \mathrm{WHO}$ Collaborating Center. The National Clinical Trials Coordinating Center has also earned this distinction. These two Cuban institutions are constantly evaluated, linked as they are to production of medicines, lab reagents and medical technologies. In Cuba, no such product can be used without CECMED authorization.

During the pandemic, the two agencies have been essential to clinical trials and approvals for use of various medications, both domestically produced and imported, and play an important role as part of a regional network through $\mathrm{PAHO} / \mathrm{WHO}$. And of course in vaccine development. 
Nearly $80 \%$ of vaccines applied in the National Immunization Program are manufactured in Cuba itself, where there are ample manufacturing facilities to produce high-quality vaccines that are also exported. The Finlay Vaccine Institute has decades of experience, and with other institutions experienced in R\&D such as the Molecular Immunology Center, has developed a vaccine candidate, SOBERANA 01. There is also a second candidate in pre-clinical studies, and I understand there are two more in the pipeline. That is, Cuba will have four COVID-19 vaccine candidates.

SOBERANA 01 has successfully completed Phase I trials that test safety, and is now in Phase II trials to test immunogenicity. Preliminary reports I've reviewed indicate the results are very good thus far. So this is good news for Cuba, but also for Latin America and the Caribbean. This is the first vaccine from our region in clinical trials, joining others listed with WHO that are being tested.

We're all pleased and proud that this Cuban vaccine is the first developed in our region, and that hopefully Phase II trials will conclude successfully, and it can begin Phase III trials in a much larger population with greater COVID-19 transmission rates, to discern its impact. If and when the trials conclude successfully, then the vaccine requires CECMED approval before use in the Cuban population and, if production exceeds domestic needs, then made available to other countries in our region and elsewhere.

MEDICC Review: Experience indicates that Cuban manufacturers have marketed their medicines and vaccines to other countries, but usually at lower prices for developing nations.

José Moya: Yes, in this case, Cuba would have a proven COVID-19 vaccine, the production capacities for domestic distribution to cover the Cuban population, and perhaps also a level of production that could be used for people throughout Latin America and the Caribbean, at much more reasonable prices.

MEDICC Review: Yet, Cuba has many challenges aheadshortages of some imported medicines, food security, the economy more broadly-that may threaten its ability to successfully "co-exist with COVID-19." In this context, what role do UN agencies play, and PAHO in particular?

José Moya: Since the start, PAHO has played a role in information sharing, as the hemispheric agency specializing in health, alerting governments and health authorities of the dangers posed by COVID-19. Our director, Dr Carissa Etienne, authorized all our country representatives to mobilize technical cooperation resources to respond to the most urgent initial needs. That's something we have done here, providing personal protection equipment (PPE) and RT-PCR tests, which are fundamental, in addition to virtual training sessions that we continue to hold between teams from the ministries and those at PAHO headquarters.

Here in Havana during the first several months, we held meetings involving the various UN agencies, PAHO itself and
Cuba's Ministry of Public Health (MINSAP) to determine how each of us, under the auspices of the UN Resident Coordinator, could mobilize resources to respond to the country's vital needs. Without exception, all answered the call: UNFPA, UNDP, FAO, everyone. And these action plans, which we review periodically with MINSAP, have been fulfilled.

Now we head into a new period, when the UN Resident Coordinator is organizing a longer-term response to COVID-19 in a number of essential areas-one of them, health. PAHO continues to take the lead in this field, but of course the socioeconomic arena is vital. There, the UN agencies specializing in production, agriculture and food are at work.

MEDICC Review: Of course now Cuba has been elected to the Executive Committee of PAHO's Directing Council. What significance do you attach to this?

José Moya: Like many countries of the Americas, Cuba was a founding member of PAHO in 1902, and since then it has had various leadership functions in PAHO/WHO. A few years ago, the World Health Assembly was chaired by Cuba's Minister of Public Health, for instance. Such important roles highlight the stature and relevance of Cuba in the field of health.

In PAHO's case, Cuba is a full participating member, and was newly elected with two other countries to the nine-member Executive Committee, as part of the regular rotation. This is good news for us here, since MINSAP delegates will have an active presence in the Committee, which meets twice a year to discuss issues that affect our region, offering technical guidance to the organization, later producing resolutions, policies and projects to be implemented by our countries. We're very pleased that Cuba has been elected.

MEDICC Review: In the midst of a deep recession in Latin America and the Caribbean, PAHO itself is facing a serious budgetary crisis. What has this meant for your offices in Cuba?

José Moya: The pandemic has certainly affected PAHO's finances. Our funding is based on contributions by member states, using a quota system. Meeting these quotas allows us to fulfill our mandate in terms of financing our offices, our incountry projects and our cooperation.

In the case of the offices here in Cuba, we're facing a difficult financial crunch, so we've concentrated resources in priority areas, fundamentally in response to COVID-19, but also others we can't neglect. We hope this situation will improve in the coming months.

MEDICC Review: Nevertheless, the pandemic has opened a Pandora's box of challenges to multilateralism, and we're even seeing 'vaccine nationalism.' How has this affected PAHO's operations? Is multilateralism relevant in times like these?

José Moya: Multilateralism is as valid and relevant as ever. Our organization has brought together the countries of the Americas for 118 years based on cooperation, solidarity and PanAmericanism-an important concept within PAHO itself. We are a technical agency, and we shouldn't permit politicization that could 


\section{We shouldn't permit politicization that could affect that spirit of cooperation and solidarity on which we were founded}

affect that spirit of cooperation and solidarity on which we were founded. We work for people's health, for the health of people in the Americas, and we do it through collaboration among our countries, South-South cooperation, triangular cooperation. That's our value.

Certainly this nationalism is affecting us, but we have to be true to our history and to our purpose. More so in these times, not only of pandemic, but also in the face of more chronic problems within health systems, of social inequalities, overcrowding of our cities, climate change. This is the scenario we have, the context. And in this scenario, we have to keep up the work and continue to cooperate.

Lastly, I think it's imperative that our countries continue to examine our health systems and how they are organized. And hopefully, one day, think much more about ways to sustain and strengthen primary health care-efficiently and with a permanent presence near where people live. I think this is one of the great challenges we have ahead. - 1 


\section{Ahora se habla más de lo frágiles que somos, y se hace más presente la pregunta acerca de cuáles son las verdaderas prioridades Reflexiones de la escritora española Belén Gopegui}

\section{Dr.Cs. Lila Castellanos-Serra}

Belén Gopegui (Madrid, 1963) Licenciada en Derecho en la Universidad Autónoma de Madrid. Novelista y guionista española. Con su ópera prima La escala de los mapas, (1993) recibió varios premios y su tercera obra, La conquista del aire, fue adaptada al cine. Belén Gopegui fue descrita como la mejor de su generación por el escritor y ensayista español Francisco Umbral. Sus novelas han sido traducidas a varios idiomas. En 2019 se publica su conferencia Ella pisó la Luna, ellas pisaron la luna, un poderoso texto que reivindica a todas las mujeres cuyos logros no han visto la luz.

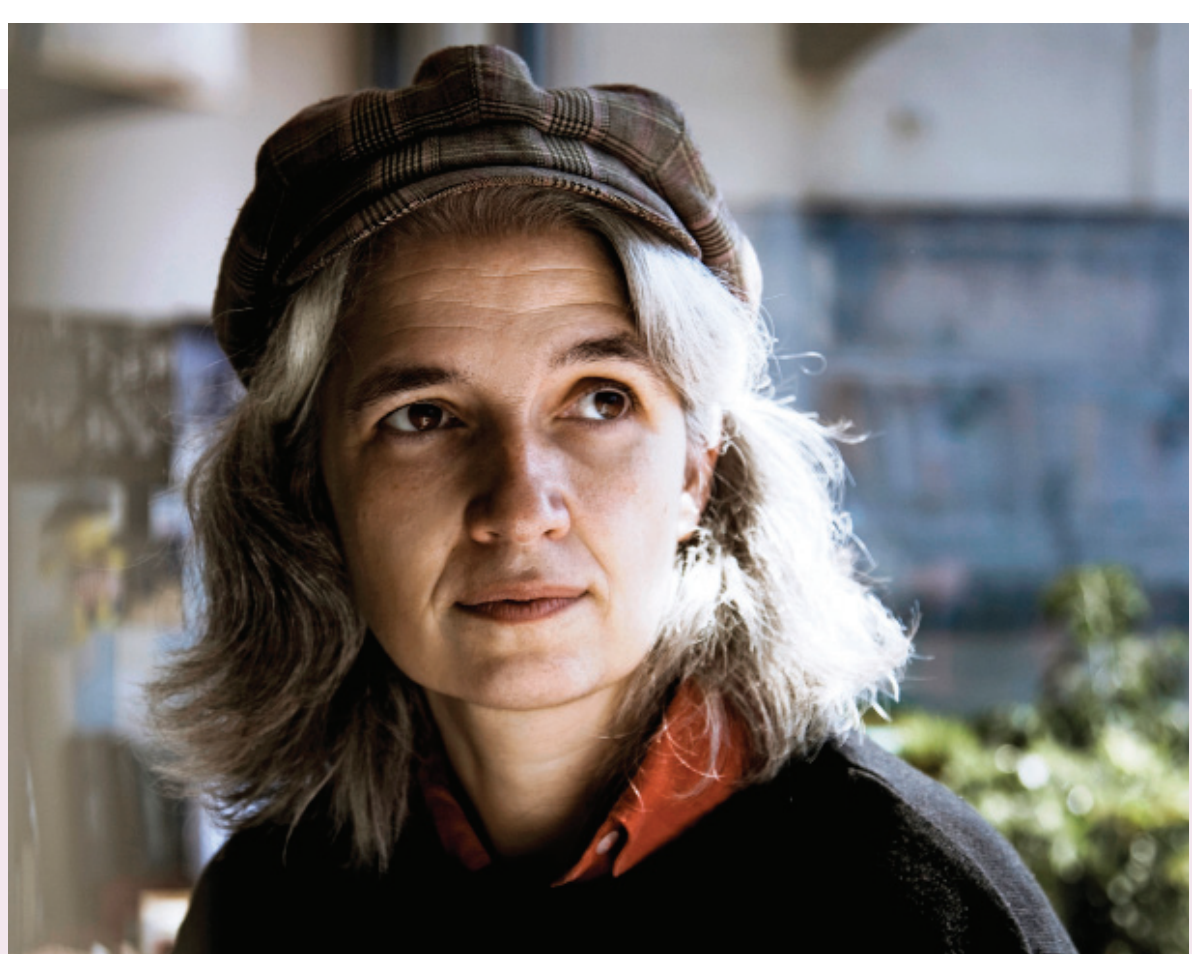

Cuando celebramos la llegada del nuevo milenio, nadie podría sospechar la sorpresa que nos deparaba el 2020. La peste medieval, el exterminio masivo de indígenas por enfermedades importadas con los conquistadores, la epidemia de Marsella de 1720-1722, las cuatro grandes epidemias de cólera del siglo XIX, la gripe de 1918-1919 -por citar algunos- parecían capítulos cerrados. Epidemias recientes como el ébola, o el cólera, muy letales pero relativamente locales, sugerían haber alcanzado cierta capacidad para limitar espacialmente los daños. Nos creíamos más allá de ciertos peligros. Hoy, la crisis mundial causada por la pandemia de COVID-19 nos descubre fragilidades que no queríamos o no podíamos ver. MEDICC Review comparte con sus lectores los puntos de vista de la escritora Belén Gopegui, una voz de la cultura hispánica respetada internacionalmente.

\section{MEDICC Review: ¿Cuál es su visión de las consecuencias de la epidemia en España?}

Belén Gopegui: Aún es muy pronto para saber qué significado va a tener esta epidemia en la mentalidad de las personas. Lo que ya vamos viendo son consecuencias directas, inmediatas, de angustia y de dolor. Coincido palabra por palabra con lo que ha escrito el periodista Ignacio Pato Lorente[1] y que dice así: "Es una atrocidad Ilamarle "cura de humildad" o "mensaje del planeta" a miles de personas lanzadas al paro, solas, mayores, asustadas, mujeres encerradas con sus maltratadores y todo el etcétera. Romantizar el "sacrificio" es una victoria liberal.
Es decir, cruel". En este momento, en la sociedad española, tanto la epidemia como la cuarentena están agudizando las desigualdades sociales que ya existían. Hay muchas personas con trabajos irregulares que no cobran y no tienen dinero ni siquiera para comprar alimentos. El confinamiento es muy diferente según donde se viva. Y muy distinto también si, cuando termine, lo que espera es un largo periodo de desempleo y/o de dificultad para sobrevivir. Si bien es cierto que va a haber algunas ayudas sociales, estas son insuficientes.

MEDICC Review: ¿Y la visión desde una óptica más amplia, planetaria?

Belén Gopegui: Es difícil dejar de pensar en todas las personas caídas, levantar la mirada y ver al planeta como una unidad, pero voy a intentar hacerlo.

Diría que la epidemia ha traído a un primer plano este pensamiento del matemático Ivar Ekeland[2]: "Caminamos anestesiados entre los riesgos que creamos. De vez en cuando, un accidente nos sacude de nuestro letargo, y echamos un vistazo al precipicio". Ahora se habla más de lo frágiles que somos, y se hace más presente la pregunta acerca de cuáles son las verdaderas prioridades y cuáles cosas que considerábamos imprescindibles resultan hoy completamente ridículas. No obstante, la realidad en que vivimos es una maquinaria que tiene su propia inercia. Deshacerla y transformarla requiere un gran esfuerzo revolucionario, un 
"sentido del momento histórico" que llegue casi a la vez a muchas poblaciones y una capacidad de conducir ese sentido. Sin embargo, como se está viendo estos días, la lógica brutal de la supervivencia, no del más apto desde el punto de vista físico -al menos en España-, pero sí de quien más dinero y patrimonio tiene acumulado, existe ya desde hace mucho tiempo. No es que se vaya a "promulgar" como algo nuevo a partir de la epidemia, es que se va a agudizar. Esa nueva sociedad basada en la coordinación y la colaboración requerirá que se derriben millares de instituciones y empresas de Occidente, y que la violencia y la desesperación encuentren cauces organizados. No es algo que, de momento, parezca próximo. Pero decir "de momento" siempre expresa una forma de confianza.

MEDICC Review: ¿Cómo la pandemia afecta las dicotomías globalización-aislacionismo, solidaridad-individualismo?

Belén Gopegui: En teoría, la pandemia deja clara la interdependencia, la idea, o más bien las evidencias sepultadas, de que no hay colectividad sin individuos ni individuos sin colectividad. Como escribí una vez "somos gotas y somos, al mismo tiempo, lluvia". Esto se ha visto con nitidez, por ejemplo, en la petición de la Comisión Europea a España y otros países miembros de abrir las fronteras para que los trabajadores temporales africanos puedan cruzarlas y así provocar la menor alteración posible en la cadena de suministro de fruta a toda la Unión. Son las mismas trabajadoras despreciadas y mal pagadas cuando recogen la fresa, los mismos temporeros alojados en barracones, sin papeles y mal pagados. Ahora se ve hasta qué punto no sólo la riqueza, también la salud de los ricos depende del trabajo de los pobres. Pero decía Graham Greene[3] que "miedo y amor son inseparables", porque temes perder lo que amas, y que son inseparables el miedo y el odio, "porque el miedo humilla". Cuando pase esta pandemia, si pasa, habrá que dedicar toda la atención a quienes ejerciendo el poder se hayan sentido humillados por sus propios errores, por su imprevisión, por las consecuencias que para sus vidas ha tenido haber discriminado y maltratado a quienes desempeñan trabajos mal pagados: habrá que velar porque no reaccionen de manera vengativa, despreciando más y odiando más.

MEDICC Review: ¿Cree que esta crisis afecta la percepción que la sociedad tiene sobre la ciencia?

Belén Gopegui: Espero que sí, y que ocurra en ambos sentidos: la percepción que la sociedad tiene sobre la ciencia y la percepción que la ciencia tiene sobre la sociedad. Creo que es bueno tener conciencia de los límites de la ciencia. No todo lo puede, no todo lo sabe, lo complicado a veces se puede abarcar pero lo complejo es mucho más difícil y las certidumbres son provisionales. Un solo contraejemplo puede obligar a replantearlo todo, la excepción puede probar que la regla es falsa. La arrogancia de quienes piensan que la ciencia es omnipotente no ayuda a comprender. Al mismo tiempo, quedan hoy confirmadas las palabras de Agustín Lage [4] en su magnífico libro La osadía de la ciencia: "Cuando se siembra ciencia en una sociedad no se obtienen solamente nuevos conocimientos o nuevas tecnologías, se siembra también una cultura de la racionalidad, objetividad, debate, crítica y verificación constante, que es fuente de ética y valores, los cuales a su vez contribuyen a la cultura general".
Lo grave es que en muchos países la ciencia se siembra mutilada, son semillas modificadas para que lo verificable quede por debajo del interés económico.

Hoy en Europa estamos pagando la consecuencia de muchos años de investigar en cotos cerrados en universidades superespecializadas, sin compartir conocimientos que, por delante del debate honesto, ponen el interés por una compensación económica, y que no se preguntan cuáles son los problemas que más investigación necesitan sino cuáles, si los resuelvo, darán mayor rentabilidad a corto plazo. La ciencia, claro está, necesita ser sostenida económicamente, no hablo de situaciones etéreas e ideales, pero lo que no tiene sentido es descuidar los problemas graves de la humanidad y dedicarse a supuestos problemas que no lo son, que no evitan sufrimiento ni ayudan a vivir.

MEDICC Review: El papel que en esta crisis están jugando los medios de comunicación y las redes sociales tiene múltiples facetas, positivas y negativas. ¿Cómo ve su impacto en la sociedad?

Belén Gopegui: Hoy las redes son un elemento más de la vida, no son un estrato diferente. Se han integrado en la vida diaria, si bien una crisis energética puede hacer que caigan y que todo lo que hoy resulta natural en ellas desaparezca. Se habla de la posverdad y es cierto que se propagan noticias falsas. Pero no hay que olvidar que antes también sucedía aunque la escala fuera menor. Antes, la supuesta verdad estaba monopolizada por los grandes medios de comunicación y hoy las redes permiten que se escuchen otras voces. Lo que, sin embargo, sigue siendo un monopolio, o varios, es la potencia de difusión. Por otro lado, las redes no son, desde un punto de vista descriptivo, redes: son esferas en manos de empresas que deciden lo que entra y lo que no.

Afortunadamente, cuando surge algo nuevo, es difícil controlarlo por completo y las redes permiten que se muestre lo mejor del ser humano, su talento masivo, su solidaridad, su humor. Pero, como decía, la potencia de difusión sigue estando en manos de los más poderosos, por lo que al final es difícil que los grandes medios y las grandes empresas no sigan marcando la pauta de qué pensar, una pauta que, según se ha visto, no se guía por el bien, ni por la verdad.

MEDICC Review: ¿Consejos para los jóvenes cuyos esfuerzos necesitaría el mundo para evitar futuras pandemias? ¿Cómo ampliar y hacer efectivo su compromiso con la sociedad en su conjunto?

Belén Gopegui: No daré consejos porque en la adolescencia y en la juventud hay un impulso muy valioso, algo que te lleva a querer buscar tu propio camino. $Y$ dado el rumbo que ha tomado este mundo en decadencia, no somos quienes, creo, para darles consejos. Pienso que lo mejor está intacto en ellos. Por eso, más que dar consejos, nuestra tarea es, quizás, desbrozar lo que les impide ver lo que tienen dentro. En todo caso, por no huir de la pregunta, acudiré a un fragmento de letra de canción que escribí hace poco para Ana Molina[5], con el deseo de que sea verdad que hayamos sabido dárselo: Lleva tú contigo/ lo que supe darte/ la razón ardiente/ y no retirarse/ cuando ya no hay sombra/ cuando arrecia el sol/ y en la noche oscura/ no brilla el farol. 
MEDICC Review: ¿Es posible, entonces, pese a todo, un cierto optimismo?

Belén Gopegui: La reacción de muchísimas personas ante esta crisis permite un cierto optimismo, en efecto, y no solo de la voluntad, también de la razón. Porque está claro que el potencial para la solidaridad, el trabajo, para darlo todo por personas a quienes no se conoce, existe y se está viendo con absoluta nitidez en el personal sanitario, por ejemplo. Empieza a desarrollarse, además, una conciencia mayor de la injusticia; en España hoy se extiende una voluntad casi general de defender la sanidad pública, de no permitir un solo hospital privado más, y tratar de nacionalizar los existentes. Más que una pregunta, lo que hay ahora por delante es una gran tarea con dos frentes: paliar el dolor y la carestía de muchísimas personas, y al mismo tiempo, impedir que la situación de desigualdad que la ha provocado vuelva a producirse.

En estos momentos queda muy claro que la ciencia y la política necesitan trabajar unidas y con un sentido emancipatorio, pues de poco sirve que la ciencia encuentre una vacuna si, durante el tiempo que tarda en encontrarla, la política no es capaz de dar apoyo a quien lo necesita. $Y$ de nada sirven las sociedades que no son capaces de compartir sus recursos sino que los acaparan por clases, por naciones, por grupos de privilegio, y de este modo retrasan la difusión del conocimiento y su avance. Me gustaría terminar con una frase hermosa, conmovedora. Pero hoy, lo único verdaderamente hermoso y conmovedor son los actos. - th

\section{NOTAS}

1. Ignacio Pato Lorente (1983-). Periodista y politólogo, ha trabajado en diversos medios de comunicación. En la actualidad escribe un ensayo sobre la crisis motivada por la pandemia de próxima aparición y forma parte del equipo del suplemento Apuntes de clase, perteneciente al medio de comunicación alternativo La Marea.

2. Ivar Ekeland (1944-). Mátemático francés. Se ha especializado en análisis funcional. Autor de numerosos libros de texto de su especialidad y de difusión sobre matemática y en particular, la teoría del caos y fractales.

3. Henry Graham Greene (1904-1991). Escritor, guionista y crítico británico. Trató en sus obras asuntos política o moralmente ambiguos en un trasfondo contemporáneo.

4. Agustín Lage Dávila (1949-). Científico cubano. Médico, especializado en inmunología del cáncer. Fundador del Centro de Inmunología Molecular de Cuba. Autor de más de 200 publicaciones científicas, también ha publicado varios libros y numerosos artículos sobre la relación entre ciencia y sociedad.

5. Ana Molina Hita (1977-). Profesora del colegio público Pío XII ubicado en el barrio de La Ventilla, al norte de Madrid, que formó con varias alumnas el grupo coral Milagros en 2012-2013. En 2020, el grupo ahora formado por 10 integrantes, ha grabado canciones con letras de Belén Gopegui.

Published: September 15, 2020

https://doi.org/10.37757/MR2020.V22.N4.1 


\section{Fallen in the Face of COVID-19: Graduates of Cuba's Latin American School of Medicine (ELAM)}

\section{Gail Reed MS}

The 2020 fall semester at Havana's Latin American School of Medicine (ELAM) began on an especially somber note: honoring 17 of its alumni felled as they battled COVID-19 in their home countries and beyond. A few were recent graduates among the 30,047 from 118 countries who received scholarships from Cuba to study medicine at ELAM. Others were members of its first graduating class in 2005.

Their service on the front lines during the pandemic reflects the school's mission to train low-income students the world over who pledge to care for communities and their patients, irre- spective of ability to pay... and often in public health facilities at no charge.

MEDICC Review joins fellow ELAM graduates, students and faculty in paying tribute to the service of these talented, dedicated young health professionals, and expresses our deepest condolences to their families, friends, colleagues and mentors.

Many of the pictures in this photo-feature are not publication quality. That's not why they were taken. Rest in peace, service, and confidence in the fact that health for all is possible.

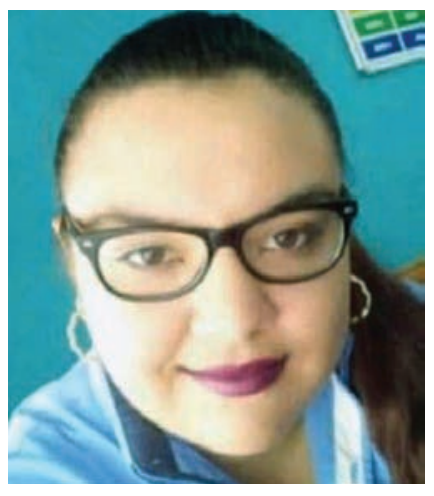

Dr. Ericka Julissa Flores Torres (1981-2020)

Peru

ELAM Class of 2005

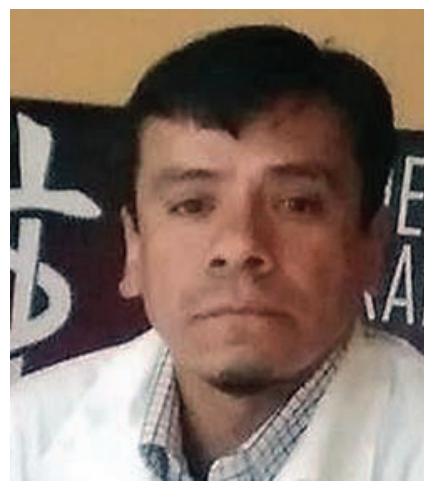

Dr. Luis Fernando Orozco Andrade (1977-2020)

Guatemala

ELAM Class of 2005

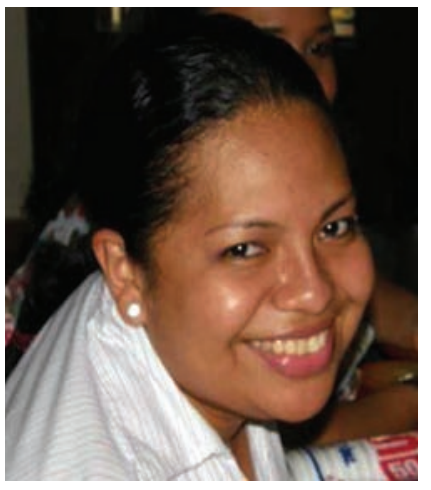

Dr. Yessenia Herrera Ruiz (1981-2020)

Panama

ELAM Class of 2005

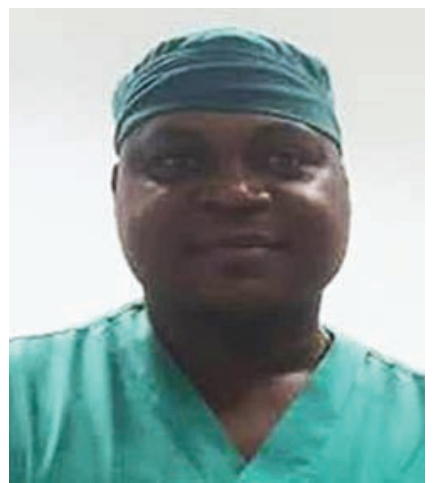

Dr. Ambrosio-Moyo Ondo Ayecaba (1974-2020)

Equatorial Guinea

ELAM Class of 2007

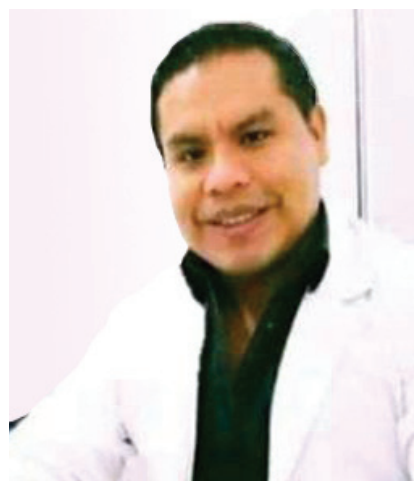

Dr. Orlando Julio Isacc King (1979-2020)

Venezuela

ELAM Class of 2005

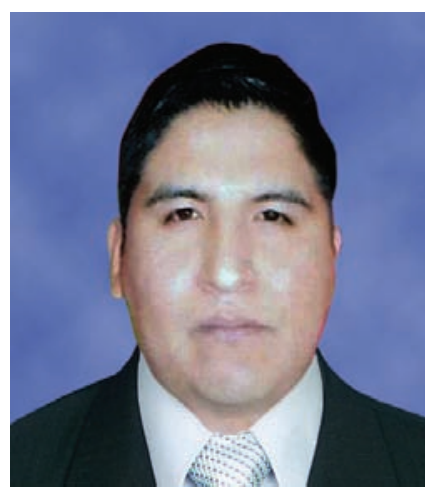

Dr. Roger Layme Salgueiro (1984-2020)

Bolivia

ELAM Class of 2011 


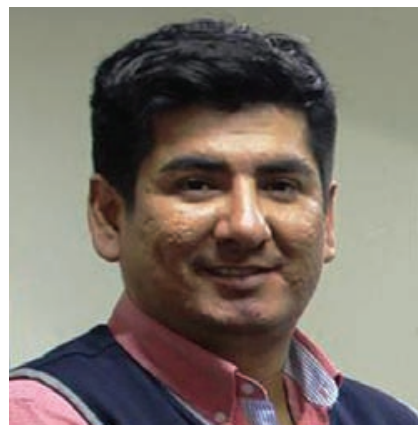

Dr. José Humberto Paredes Abanto (1988-2020)

Peru

ELAM Class of 2011

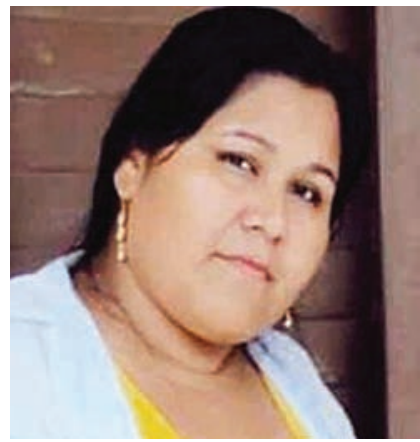

Dr. Sara Chambi Méndez (1988-2020)

Bolivia

ELAM Class of 2012

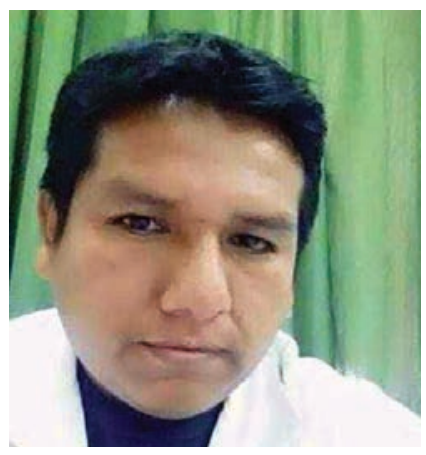

Dr. Juan Orellana Cardenas (1986-2020)

Bolivia

ELAM Class of 2012

Dr. Jhonny Josué Nilton Villegas Atora (1986-2020)

Bolivia

ELAM Class of 2012

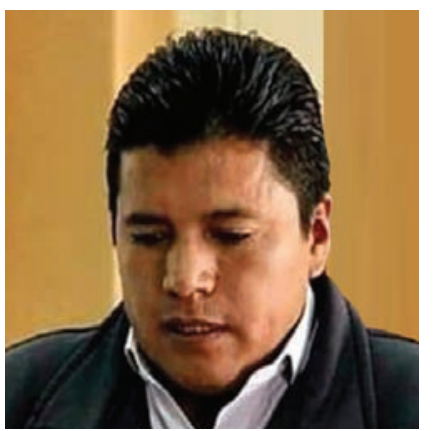

Dr. Edgar Patricio Aynaguano Uño (1984-2020)

Ecuador

ELAM Class of 2012

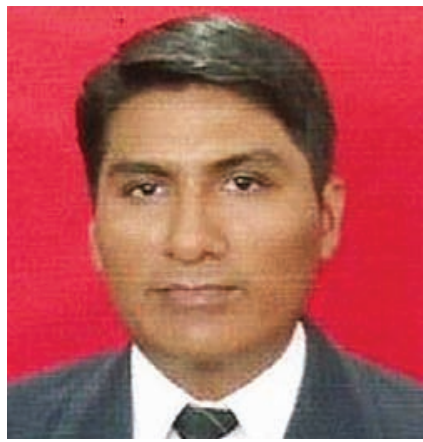

Dr. Nemecio Choque Niño (1983-2020)

Bolivia

ELAM Class of 2012

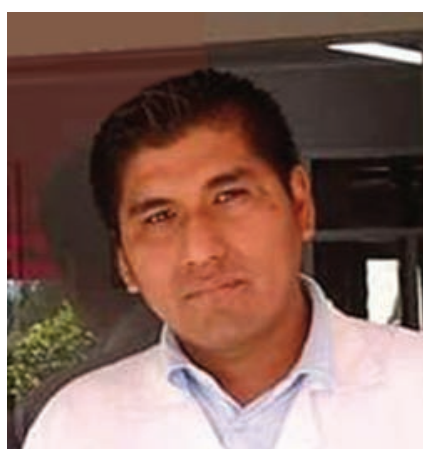

Dr. Hebert Ortuño Vallejos (1985-2020)

Bolivia

ELAM Class of 2012

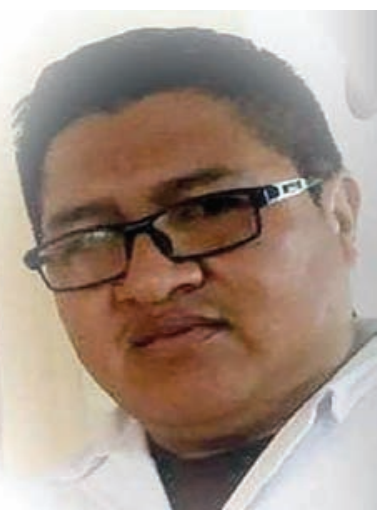

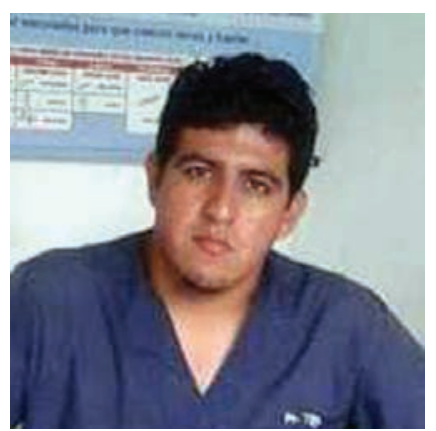

Dr. Mariano Luis Barrios Lijerón (1989-2020)

Bolivia

ELAM Class of 2012

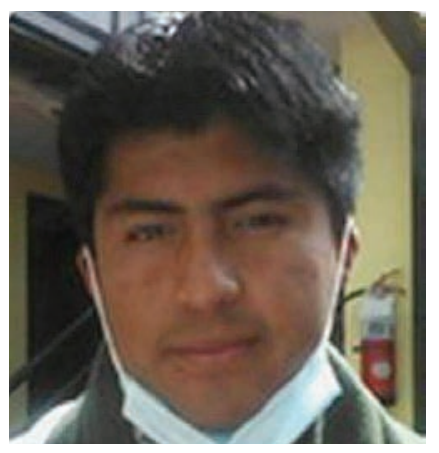

Dr. Martín Adolfo Morales Figueredo (1986-2020)

Bolivia

ELAM Class of 2012

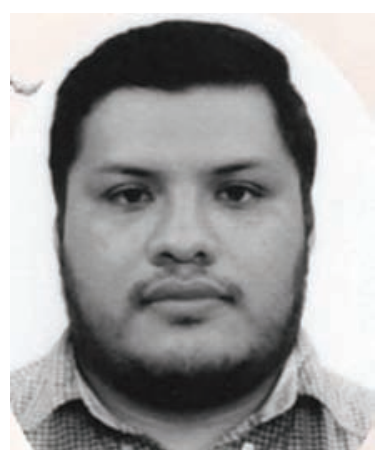

Dr. Job Gerardo Villanueva Núñez (1987-2020)

Honduras

ELAM Class of 2012

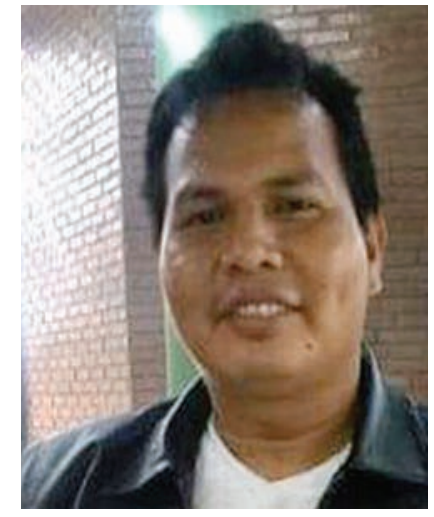

Dr. Alberto Arteaga Jiménez (1985-2020)

Bolivia

ELAM Class of 2013

https://doi.org/10.37757/MR2020.V22.N4.13 


\title{
COVID-19 in Cuba: Assessing the National Response
}

\author{
Enrique Galbán-García MD PhD, Pedro Más-Bermejo MD PhD DSc
}

\begin{abstract}
The COVID-19 pandemic exhibits different characteristics in each country, related to the extent of SARS-CoV-2 local transmission, as well as the speed and effectiveness of epidemic response implemented by authorities. This study presents a descriptive epidemiological analysis of the daily and cumulative incidence of confirmed cases and deaths in Cuba from COVID-19 in the first 110 days after first-case confirmation on March 11, 2020. During this period, 2340 cases (20.7 x 100,000 population) were confirmed, of which 86 patients died (case fatality $3.67 \% ; 52$ men and 34 women). Mean age of the deceased was 73.6 years (with a minimum of 35 years and a maximum of 101), with the average age of men lower than that of women. More than $70 \%$ of all deceased had associated noncommunicable diseases. The incidence curve ascended for five weeks and then descended steadily. The average number of confirmed cases and deaths for the last week included (June 23-28, 2020) were 25 and 1 respectively; the curve always moved within the most favorable forecast zone of
\end{abstract}

\section{INTRODUCTION}

COVID-19, aided in its spread by the rapid and extensive international movement of people and goods, was designated a global pandemic by WHO in March 2020, after its initial onset in China in late 2019. Epidemics of other coronaviruses producing severe respiratory symptoms, such as SARS-CoV-1 in 2002[1] and MERS-CoV in 2012,[2] never earned this designation.

The susceptibility of an epidemiologically-naive world population to COVID-19's etiological agent, SARS-CoV-2, and its basic reproduction number $\left(R_{0}\right)$ (initially estimated to be between 2 and 3 ), favored wide penetration of human communities and resulted in far-reaching chains of transmission from almost all infected individuals.[3] Compared to other diseases caused by coronaviruses, COVID-19 has resulted in a large number of severe cases and deaths, leading to a high global case fatality rate ( $>5 \%$ during the period analyzed),[3] at a time when preventive or curative treatments specific to the virus (antiviral drugs or vaccines) were not yet available.

The magnitude of this disease and its clinical implications have been such that within just the first 6 months after its identification, more than 10 million cases and 50,000 deaths were recorded.[4] Given these figures, it is unsurprising that health services in many population centers worldwide were strained and, in some cases, even overwhelmed.

\section{IMPORTANCE}

This paper describes and analyzes the characteristics of Cuba's response to the COVID-19 epidemic during the first 110 days after the first case was diagnosed. It highlights the particularities and the participation of the country's healthcare system, scientific community and government in confronting the disease. available mathematical models and the effective reproductive number fell below 1 after the fifth week following the onset of the epidemic.

We present the prevention and control measures implemented during this period-some unique to Cuba-and assess their effectiveness using two analytical tools: comparison of observed deaths and confirmed cases with those predicted by mathematical models; and estimation of the effective reproductive rate of SARS-CoV-2. Some distinctive features of this strategy include nationwide door-to-door active screening for individuals with fever and/or symptoms of respiratory distress, isolation of cases and quarantine of contacts of confirmed cases and of persons suspected of having the virus. During this period, Cuba's response to the epidemic was successful in flattening the curve and limiting transmission, resulting in fewer cases and a lower number of subsequent deaths.

KEYWORDS COVID-19, SARS-CoV-2, epidemiology, pandemic, emerging infectious disease, contact tracing, patient isolation, Cuba
The pandemic has manifested differently in each country, both in terms of the level to which various communities have been affected, and authorities' response to the disease, including transmission prevention and containment measures. As of June 28, 2020, global data reveal the United States and Brazil as the countries with the most confirmed cases and the most deaths from COVID-19, with cases in the millions and deaths in the hundreds of thousands in each. Countries such as Russia, India, the United Kingdom, Peru, Chile, Spain, Iran, Mexico, Pakistan, Turkey, Germany, France and South Africa also report very high case numbers and deaths.[4]

In other countries-including Iceland, Paraguay, Uruguay, Lebanon, Slovakia, Lithuania, Latvia, Costa Rica and Jamaicathe epidemic has evolved more favorably, despite recent outbreaks in some. A group of countries on the African continent are reporting low or moderate numbers of confirmed cases and deaths, but the pandemic started later in that region and could still be considered in its initial period.[4]

When comparing the numbers of confirmed cases and deaths between different countries, factors both intrinsic and extrinsic to SARS-CoV-2 must be considered. For example, the number of cases at any given point depends on the time the epidemic has been developing in each nation, the intensity of case detection (measured in the number of confirmatory tests carried out per million inhabitants), as well as on the virus's pathogenicity, virulence and transmissibility. These last three factors have been common to all regions, regardless of the genomic variants identified to date.[5]

Statistics on the number of cases, case fatality rates and other indices specific to each country depend on the mitigation strategies adopted and how the data are compiled.[6] In Cuba, positive cases, their contacts and suspected cases (the latter identified through active, door-to-door screening) are isolated either in health institutions or in centers adapted for this purpose.[7] In other 
countries, responsibilities for isolation and reporting are often left to individual households, which can increase the likelihood of underreporting in the absence of contact tracing, given that many of these cases may be asymptomatic. Recording cause of death of a patient with a severe comorbidity such as cancer or chronic kidney disease who is also positive for SARS-CoV-2 adds to reporting differences depending on the practices of each country, and misreporting increases when a high proportion of deaths occur in the home. The number of tests carried out can also modify the statistics, as the greater the number of individuals tested, the greater the number of less-severe infections detected, which will then show a drop in the overall case fatality rate.

Finally, the case fatality rate also depends on factors such as the average age of the population (older populations tend to increase case fatality), prevalence of underlying chronic noncommunicable diseases (comorbidities), and the strain placed on health services (either exhaustion or infection of healthcare personnel attending COVID-19 cases, or when health services have been overwhelmed and are thus unable to care for the patient load).

This paper analyzes the particular characteristics of Cuba's response to the COVID-19 epidemic, as well as participation of the country's health system, scientific community and government in confronting it.

\section{THE COVID-19 EPIDEMIC IN CUBA}

The first three cases (all Italian tourists) were identified on March 11, 2020. This date represents the start of the epidemic in Cuba. In the following 110 days (through June 28, 2020), 2340 cases of COVID-19 were confirmed, and 86 of those individuals died from the disease. Of the total infected, $162(7.0 \%)$ acquired the disease abroad, returning to Cuba within the virus's incubation period.

Figure 1 shows the number of cases diagnosed daily during this period. The extreme values are between 0 and 74 with an average of 21 cases/day, while case detection, always confirmed by realtime polymerase chain reaction (RT-PCR) increased throughout the period, resulting in $>168,000$ tests with an average of 1500 2000 daily, totaling almost 15,000 per million population by the end of the 110-day period.

Figure 1: Moving average trend of COVID-19-confirmed cases in Cuba, for $\mathbf{1 1 0}$ days after first-case diagnosis

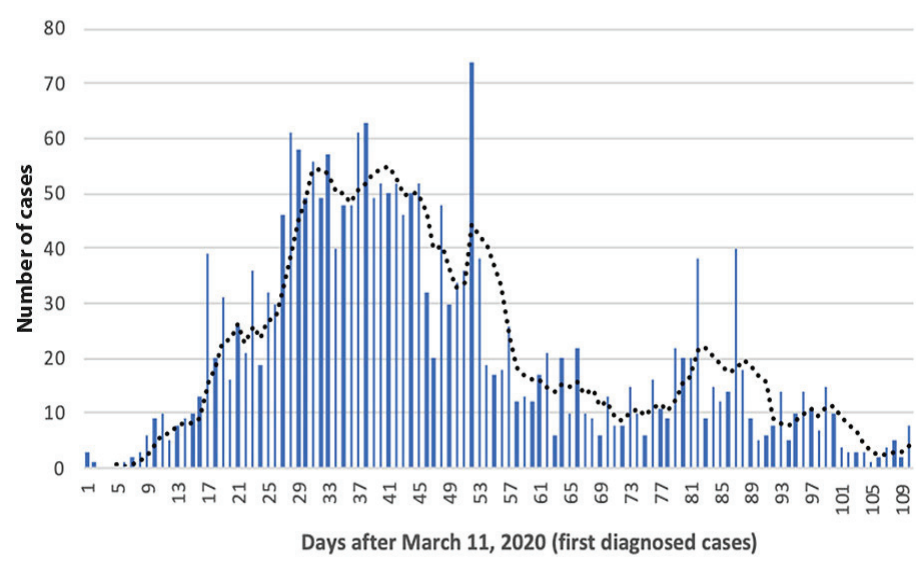

Source: Daily report of confirmed COVID-19 cases. Ministry of Public Health, Cuba. Available at: https://salud.msp.gob.cul
The highest number of confirmed cases for one day coincided with outbreaks of local transmission in two institutions where vulnerable people lived (a nursing home and a social security institution where 47 and 58 cases were identified, respectively). In this period, small- and moderate-sized outbreaks were relatively frequent, mainly within family groups and involving some sort of violation of established preventive measures, as revealed in epidemiological followup.[8]

The trend line calculated by five-day moving averages (Figure 1) smooths out the short-term fluctuations derived from the time elapsed between identification of suspected cases or contacts of primary cases and the sampling, transportation, RT-PCR testing and the cutoff timing for including results in the national registry and reporting system. The confirmed curve shows a rise of just over a month in duration, followed by a plateau lasting for approximately 15 days. The descent begins near day 45 and is interrupted only briefly by spikes in cases associated with the outbreaks already mentioned. The weekly case record corroborates our earlier assertion that the curve has a 5-week ascending arm and then begins to descend for the next 11 weeks (Figure 2).

During the 110-day period studied, the 2340 people infected with the SARS-CoV-2 virus constituted a national incidence rate of 20.7 per 100,000 population. Of this total, 1174 were men $(50.2 \%)$ and 1166 women (49.8\%); $162(7.0 \%)$ acquired the infection abroad, mainly in the USA and Spain, countries with significant travel to and from Cuba. The largest number of cases sorted according to geographic area occurred in western Cuba, specifically in Havana, the capital and most cosmopolitan city. Havana alone accounted for $54.7 \%$ of the country's total cases.

As a result of contact tracing, $88.4 \%$ of confirmed cases were traced to previously confirmed cases, and $54 \%$ were identified when asymptomatic or presymptomatic, suggesting that most were found in the early stages of infection. This has probably

\section{Figure 2: COVID-19 cases in Cuba by week}

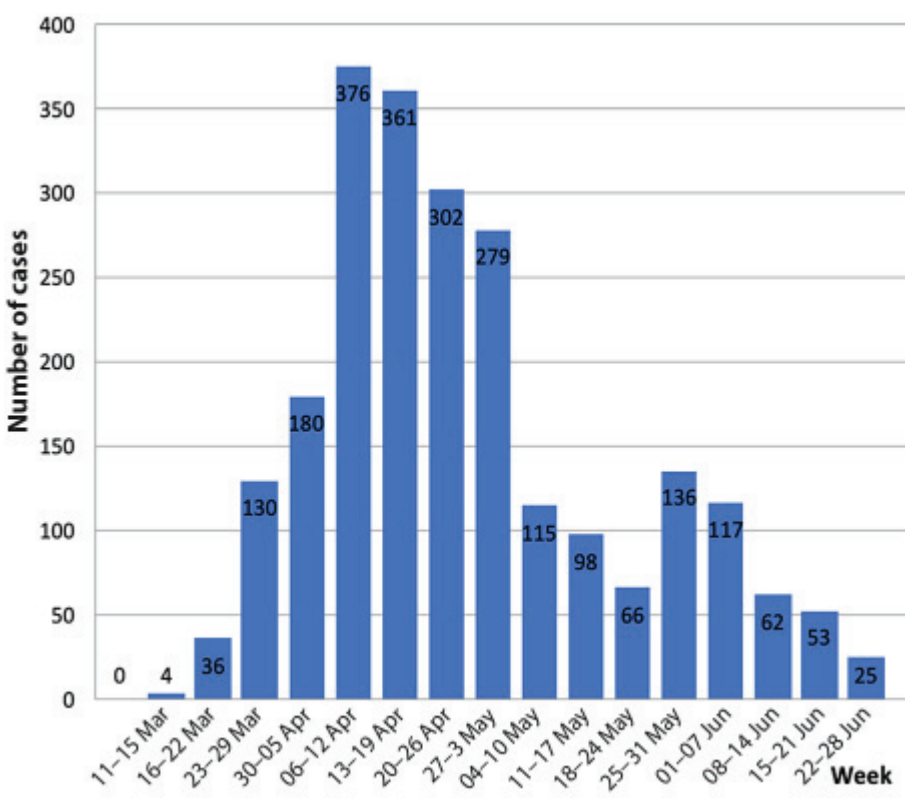

Source: Daily report of confirmed COVID-19 cases. Ministry of Public Health, Cuba. Available at: https://salud.msp.gob.cu/ 
contributed to reducing SARS-CoV-2 transmission in Cuba, as contacts that are traced from previously confirmed cases are referred for quarantine in isolation centers for the maximum incubation period counted from the most recent exposure that contact had with their index case.[7]

Total confirmed cases included persons from 1 year to 101 years of age. For the purposes of this analysis, they were divided into the following age groups: <20 (12.4\%); 20-39 (29.9\%); 40-59 $(35.6 \%)$; and $\geq 60(22.1 \%)$ years.

In the 110-day period studied COVID-19 was the cause of 86 deaths, resulting in case fatality rate of $3.7 \%$. This rate in Cuba was lower than that reported worldwide $(4.96 \%)$ and lower than that of Latin America (4.8\%) in the same time frame. The monthly case fatality rate decreased to $1.2 \%$ in June. Of the 86 deceased, $52(60.5 \%)$ were men and $34(39.5 \%)$ women, with case fatality considerably higher for men $(4.4 \%$ vs. $2.9 \%)$, despite the fact that the average age of men was lower (70 years vs. 79.1 years). The deceased included two non-Cubans (one Russian and one Italian), and a Cuban national residing in Spain, all of whom were infected abroad.

Of the deceased, $85 \%$ had a history of one or more serious chronic non-communicable disease (NCD) comorbidities. Table 1 summarizes the most common NCDs associated with SARSCoV-2 infection in the 86 people who died. High blood pressure and diabetes mellitus were the most frequent, which concurs with reports in the international literature.[9] Given the wide range of comorbidities that sometimes accompany positive cases it is not possible to assume that COVID-19 was the primary cause of death in all cases, although older adults and people of any age with serious underlying conditions are known to be at increased risk of becoming seriously ill and dying if infected with SARSCoV-2.[10]

Figure 3 shows the results of estimating the effective reproductive number $\mathrm{R}_{\mathrm{t}}$ using daily data from new cases reported between March 11 and June 28, 2020 across Cuba. The dark line corresponds to the mean of each value and the shaded lines correspond to $95 \%$ confidence intervals. $R_{t}$ expresses the epidemic's reproduction ratio; a key goal for stemming any epidemic is to achieve $R_{t}<1$, indicating that infected individuals are not causing new cases. Both $R_{t}$ and $R_{0}$ by themselves are insufficient measures to characterize

Table 1: Most frequent comorbidities associated with COVID-19 deaths in Cuba, by sex, March 11-June 28, 2020

\begin{tabular}{|l|r|r|r|r|r|r|}
\multirow{2}{*}{ Comorbidity } & \multicolumn{2}{|c|}{$\begin{array}{c}\text { Women } \\
\mathbf{N}=\mathbf{3 4}\end{array}$} & \multicolumn{2}{c|}{$\begin{array}{c}\text { Men } \\
\mathbf{N}=\mathbf{5 2}\end{array}$} & \multicolumn{2}{c|}{$\begin{array}{c}\text { Total * } \\
\mathbf{N}=\mathbf{8 6}\end{array}$} \\
\cline { 2 - 8 } & No. & \multicolumn{1}{c}{$\%$} & No. & \multicolumn{1}{c|}{$\%$} & No. & \multicolumn{1}{c|}{$\%$} \\
\hline Arterial hypertension & 13 & 38.2 & 30 & 57.7 & 43 & 50.0 \\
\hline Diabetes mellitus & 15 & 44.1 & 18 & 34.6 & 33 & 38.4 \\
\hline Ischemic heart disease & 6 & 17.6 & 13 & 25.0 & 19 & 22.1 \\
\hline $\begin{array}{l}\text { Chronic obstructive pulmonary } \\
\text { disease }\end{array}$ & 3 & 8.8 & 9 & 17.3 & 12 & 14.0 \\
\hline Chronic kidney disease & 5 & 14.7 & 8 & 15.4 & 13 & 15.1 \\
\hline Cancer & 1 & 2.9 & 8 & 15.4 & 9 & 10.5 \\
\hline Dementia & 4 & 11.8 & 3 & 5.8 & 7 & 8.1 \\
\hline Heart failure & 3 & 8.8 & 1 & 1.9 & 4 & 4.7 \\
\hline
\end{tabular}

Source: epidemiological case histories

*A deceased individual may have had more than one comorbidity the dynamics of any disease in a population, but they have value as a complement to other indicators, as illustrated in the Cuban experience.

Figure 3: Effective reproductive number $\left(R_{t}\right)$ for COVID-19 cases in Cuba, March 2-July 6, 2020

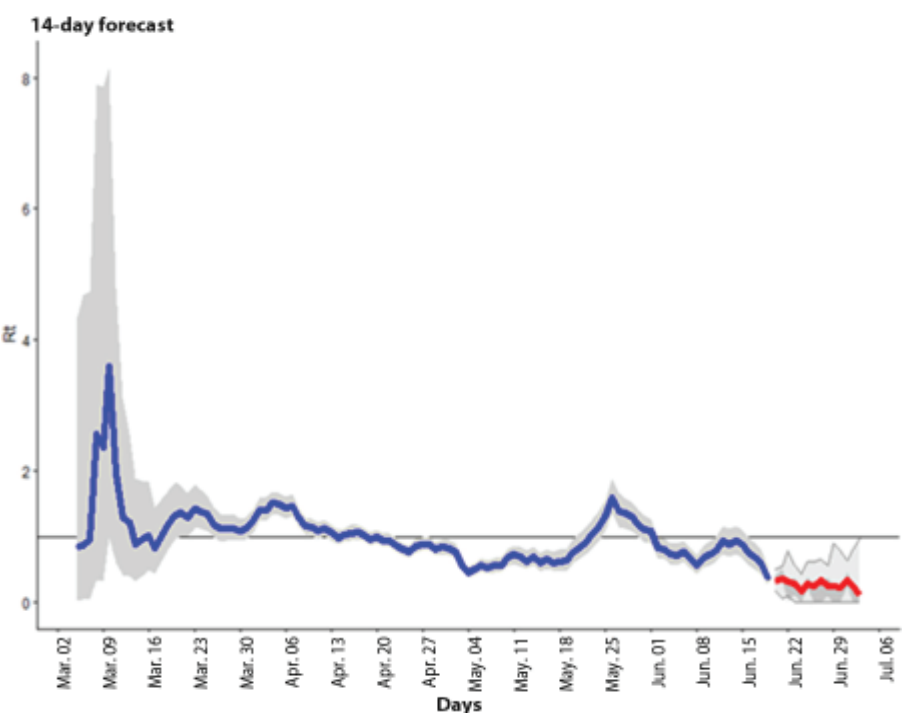

Calculated using symptom onset date for each patient. Serial interval distribution, using the Anne Cori method.[11] Author: Dr Waldemar Baldoquin. Pedro Kourí Tropical Medicine Institute, Cuba

The effective reproduction number $R_{t}$ differs from the basic reproduction number $R_{0}$ in that it changes over time and depends on the true susceptibility of the population.[11] $R_{t}$ has been estimated periodically during the first 110 days after the first confirmed case. In the first few days, high values (close to 5) can be observed in Figure 3, which is consistent with the exponential dynamics of the COVID-19 epidemics in many countries.[12] For the next 15 days, $R_{t}$ began a sustained decline, reaching values slightly above 1 , until later in the seventh week when it fell below this limit $\left(R_{t}<1\right)$. This indicator temporarily spiked above 1 during a local transmission outbreak, but once it was controlled, $R_{t}$ continued to fall. At the end of the 110-day period, the red portion of the figure demonstrates that even the upper value of the $95 \%$ interval is $<1$, suggesting that the transmission rate has slowed, consistent with the introduction of prevention and containment measures.

\section{CONFRONTING COVID-19:}

\section{CUBAN STRATEGIES AND RESULTS}

Among the decisions taken by Cuban authorities was to gather specialists in biomedical, hard and social sciences into a Technical Advisory Team within the Ministry of Public Health. The team was tasked with periodically analyzing the epidemic situation, identifying problems and recommending solutions for different scenarios. Among other things, this facilitated incorporation of new treatments and innovations for improved patient care, as well as timely predictions useful in guiding strategies for controlling the epidemic. The contribution of Cuban institutions and scientists has been recognized in the media by government and health authorities.[13]

Researchers from the University of Havana's Mathematics Department applied several prognostic models for the course of 
the epidemic in Cuba (Figure 4). The SIR model (SusceptibleInfected-Recovered), based on a system of ordinary differential equations, has been used elsewhere and was chosen due to its simplicity and ease of interpretation.[14,15] Figure 4 shows the expected case curves in three theoretically possible scenarios (favorable, moderate and critical). The active confirmed cases reported each day are registered in black (total cases minus those recovered or deceased).

Figure 4: SIR forecast model of hospitalized COVID-19 cases diagnosed up to 106 days after epidemic's start and projected epidemiological scenarios for the epidemic in Cuba. March-July 2020

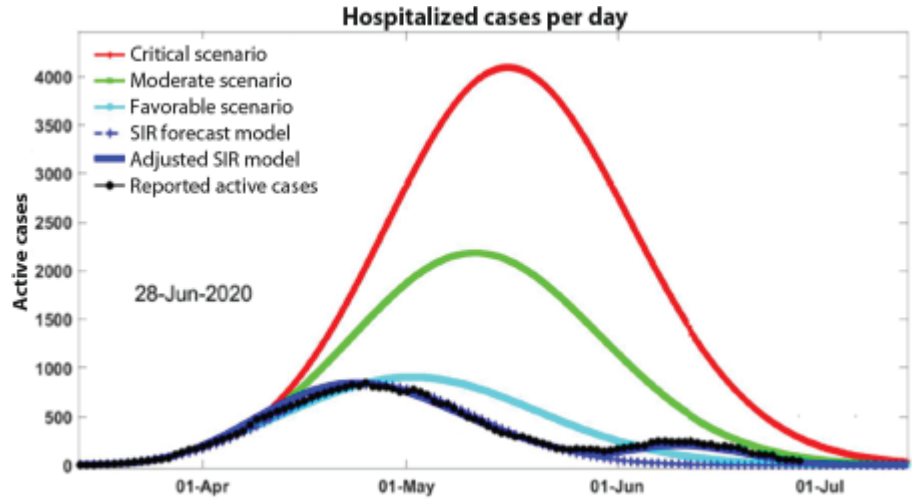

Source: Dr Raúl Guinovart. Mathematics Faculty, University of Havana

The Cuban strategy included active screening for persons with asymptomatic infections. This was supported by the use of an epidemiological surveillance system (which tracks the location and contacts of potential vectors of communicable diseases) in place throughout the country for many years before the appearance of COVID-19.[7,16] This explains why $54 \%$ of confirmed cases were either in asymptomatic or presymptomatic stages at the time of their confirmation, and the share of asymptomatic cases continued to increase as the epidemic evolved, reaching close to $70 \%$ in the final weeks of the 110-day period.

Surveillance of international travelers was established before the first cases were confirmed in Cuba, and two weeks after these confirmations (on March 24, 2020), the decision was made to close airports to international flights.[17] Before closing the airports on March 24, contacts of COVID-19-positive cases (declared 'suspected cases') were advised to remain quarantined for 14 days in hospital centers outfitted for this purpose, or were monitored at home for the same period by primary healthcare personnel, restricting movement outside and maintaining physical distancing. This made it possible to trace all contacts of the first detected case. All these contacts underwent RT-PCR tests between the third and fourth days of their quarantine, and those with symptoms were referred to hospital centers with a higher level of clinical capacity.[7] At no time during the 110 days did COVID-19 patient care cause either primary care facilities or hospital emergency services to collapse, and intensive-care unit (ICU) capacities were always available. At the end of this period, a total of 39 infected persons were still in hospital with COVID-19, one of them in the ICU.

It is known that SARS-CoV-2 infection can spread rapidly in hospital settings.[18,19] This was also the case in Cuba, where
291 hospital workers were infected (12.1\% of cases), including 212 doctors and nursing staff, with no deaths among them.

To achieve physical and social distancing at the population level, government authorities eliminated large public gatherings, closed schools and non-essential workplaces, and limited public transportation, among other measures, recommending in a massive public information campaign that people wash or disinfect hands regularly, use face masks outside and leave home only when necessary. Public messaging emphasized the importance of these habits for all individuals, especially for highrisk groups. Measures were more restrictive in communities with local transmission outbreaks or a large number of cases.[17] Various researchers have concluded that such strategies are effective for cutting the chain of person-to-person transmission of SARS-CoV-2. All of these interventions are included in $\mathrm{WHO}$ guidelines for confronting the pandemic[12] and in the Oxford COVID-19 Government Response Tracker (OXCGRT).[20] OXCGRT was developed by Oxford University (UK) as a tool to assess government response to the pandemic which achieved and maintained a rating of 100 since May 11, 2020 (ratings are assigned from 1 to 100 , based on an aggregate of 17 indicators measuring government response to the pandemic).[20]

The Cuban strategy has also incorporated nationwide door-to-door screening for persons presenting with fever and/or respiratory symptoms, carried out by primary care professionals supported by medical sciences students.[7] Additionally, an application ('app') for mobile devices (a 'virtual screener') was developed for people to self-evaluate and indicate if they present symptoms, which then advises local health authorities so that a primary healthcare service provider can visit them at home.[21] Both components of the strategy have provided valuable complementary epidemiological information on presence of possible clinical cases of COVID-19 and have opened up new possibilities for surveillance and control of other diseases in the future.

Research is continuing to identify asymptomatic cases in various population groups in response to WHO's call for population-based serological studies at the local or national level.[22] A national infection prevalence survey based on infection research (RT-PCR and antibody testing) is also being conducted in a probabilistic sample representative of the entire Cuban population that includes 4000 people of all ages and 1300 households.

\section{DISCUSSION}

The COVID-19 epidemic in Cuba began after those in Asia, Europe, North America and in various other Latin American countries, which means that it is several days or weeks younger than epidemics in other countries of the hemisphere (the USA, Canada, Mexico, Dominican Republic, Brazil, Ecuador, Chile or Peru, among others).[23] The day of the highest recorded number of cases in Cuba (74) was due to an outbreak in an institution, home to a highly vulnerable population, which contributed 88 cases to the cumulative total. This means the peak of the Cuban epidemic during this 110-day period was not associated with identification of active cases scattered among residents of different communities. A sustained decline of confirmed cases was recorded, beginning after a second peak of 63 cases on April 17,2020 . On that day the total number of accumulated cases was fewer than 1000 (986). The day when the maximum number of 
cases was recorded (day 74) was accompanied by one reported death and 32 accumulated deaths.

The main epidemiological indicators associated with morbidity (number of confirmed cases, incidence rate, doubling time of cases, contacts traced, rate of tests per million population) have been consistent with the drop in infections made possible by efforts to detect both asymptomatic and symptomatic individuals and followup with their contacts. Thus, more than $85 \%$ of confirmed cases were contacts of previous cases. The level of virus penetration and the population's immune level to SARS-CoV-2 is still unknown but may be elucidated by the serological study currently being conducted in a representative sample of the population.

The $>14,000$ RT-PCR tests carried out per million population $(\mathrm{pmp})$ is considered a good indicator of case finding, especially since it has been guided by active case detection carried out at the primary care level for both asymptomatic contacts as well as persons with respiratory symptoms. However, the country continues to work to obtain resources to increase this indicator (pmp) to the extent that the complex economic situation allows.

Active nationwide door-to-door screening for symptomatic cases through use of the primary healthcare system and medical schools, admission of all positive cases to hospitals and testing of all their known contacts are typical characteristics of the Cuban response to the COVID-19 epidemic. All these ensured that necessary care arrived in a timely manner, before complications. These measures may also have contributed to the relatively low case fatality rate that was observed in the country, as most fatalities occurred in persons with an average age of 74 years, almost all of whom (85\%) had concurrent underlying NCDs. This indicator (case fatality rate) was lower than the global average and the average for countries of the western hemisphere calculated within the same date range.[24] Additionally, the percentage of deaths among seriously ill patients and among critically ill patients (those requiring respiration assistance), at less than $20 \%$, is much lower than that reported elsewhere in the literature, which ranges between $50 \%$ and $70 \% .[7,10]$

Available epidemiological indicators suggest that timely introduction of social distancing (begun on March 24, 2020 in Cuba) is recognized as an effective means of reducing transmission. This may help explain Cuba's favorable results during this period in flattening the curve of infection.

The timing of measures adopted and the intensity with which they were applied decreased opportunities for transmission between contacts, which in turn contributed to reaching the peak of the epidemic faster and with a relatively lower number of cumulative deaths during this period.

In the database available from Johns Hopkins University, USA, comparing rates of infection near epidemic day 60 in 10 Latin American countries revealed that the only country exhibiting an already flattened curve was Cuba. Costa Rica and Uruguay had begun to stabilize their curves at this point, while Peru and Brazil had the highest rates of multiplying cases.[25]

By the end of June 2020, 14 of the 15 provinces of Cuba and the special municipality of the Isle of Youth had reported no new cases for $>15$ days (in some provinces, for $>30$ days). This was one of several main criteria that allowed these territories to transition to the first of three recovery phases contemplated in the national strategy for the country's gradual reopening. Havana was the last province to achieve that certification, beginning Phase 1 on July 3,2020 , the same day that the rest of the provinces (except Matanzas) entered Phase 2.[7]

Cuba's response to the epidemic has been multisectoral.[25] The Ministry of Public Health, in charge of organizing Cuba's free and universal health services at all levels of care, has assumed technical leadership. However, the role of Civil Defense, already a key player during other disasters and epidemics in Cuba, merits recognition. Another key component of the Cuban strategy has been the contribution by scientists and their institutions as advisors to government for the design and application of various strategies, ranging from the epidemiological to patient care and development of vaccine candidates.[13] Last but not least, an essential pillar of the Cuban strategy has been collaboration by the Cuban public in adopting the measures designed and implemented by the healthcare system and government authorities.

\section{CONCLUSIONS}

During the period studied, Cuba's response to the epidemic has been among the most successful, in terms of flattening the curve and limiting viral transmission in a relatively short time, resulting in relatively low case numbers and deaths. Strategies particular to Cuba's epidemic response included building on the universal character of the health system and its strong primary care network by carrying out nationwide door-to-door screening for persons with febrile and respiratory symptoms, isolating confirmed cases and placing their traced contacts and suspected cases under quarantine, as well as early inclusion of researchers and scientific institutions in the design and structure of the strategies adopted. $-1 /$ -

\section{REFERENCES}

1. Wilder-Smith A, Chiew CJ, Lee VJ. Can we contain the COVID-19 outbreak with the same measures as for SARS? Lancet Infect Dis. 2020 May;20(5):e102-7.

2. Maurice M. Too many unknowns stymie response to MERS. Lancet. 2014 Jul 5;386(9988):15.

3. Anderson RM, Heesterbeek $\mathrm{H}$, Klinkenberg D, Jollingsworth TD. How will country-based mitigation measures influence the course of the Covid-19 epidemic? Lancet. 2020 Mar 21;395(10228):931-4.

4. Coronavirus update [Internet]. [place unknown]: Worldometer; [updated 2020 Jun 28; cited 2020 Jun 30]. Available at: http//www.worldometers.info
5. Foster P, Foster L, Renfrew C, Foster M. [Phylogenetic network analysis of SARS-CoV-2 genomes. PNAS [Internet]. 2020 Apr 28 [cited 2020 Jun 10];117(17):9241-3. Available at: https://www.pnas.org/content/117/17/9241. Spanish.

6. Peláez $\mathrm{O}$, Más P. Brotes, epidemias, eventos y otros términos epidemiológicos de uso cotidiano. Rev Cubana Salud Pública. 2020;46(2):e2358. Spanish.

7. Ministry of Public Health (CU). Protocolo de Actuación Nacional para COVID19 [Internet]. Havana: Ministry of Public Health (CU); 2020 May 14 [cited 2020 Jun 10]. 131 p. Available at: https://
files.sld.cu/editorhome/files/2020/05/MINSAP Protocolo-de-Actuaci\%c3\%b3n-Nacional-para -la-COVID-19_versi\%c3\%b3n-1.4_mayo-2020 .pdf. Spanish.

8. Díaz YJS. ¿Qué se sabe del evento de transmisión local abierto en un hogar de ancianos en Santa Clara? [Internet]. Havana: Cubadebate; 2020 [cited 2020 Aug 29]. Available at: http://www .cubadebate.cu/especiales/2020/04/21/que-se -sabe-del-evento-de-transmision-local-abierto -en-un-hogar-de-ancianos-en-santa-clara/. Spanish.

9. Swift $D$. Tasa de Mortalidad más alta en pacientes con COVID19 tratados con ventilación mecánica en muestra grande. Manhattan: Medscape; 2020 
Apr 21 [cited 2020 May 28]. Available at: https:// espanol.medscape.com/verarticulo/5905324. Spanish.

10. Zhou F, Yu T, Du R, Fan G, Liu Y, Liu Z, et al. Clinical course and risk factors for mortality of adult impatiens with COVID-19 in Wuhan, China: a retrospective study. Lancet. 2020 Mar 28;395(10229):1954-62.

11. Cori A, Ferguson NM, Fraser C, Cauchemez S. A new framework and software to estimate timevarying reproduction numbers during epidemics. Am J Epidemiol. 2013 Nov 1;178(9):1505-12

12. World Health Organization [Internet]. Geneva: World Health Organization; c2020. Publications. Overview. Clinical management of COVID-19; 2020 May 27 [cited 2020 Jun 10]. Available at: https://www.who.int/publications/i/item/clinical -management-of-covid-19

13. Díaz Canel M, Núñez Jover J. Gestión gubernamental y ciencia cubana en el enfrentamiento a la COVID-19. An Acad Cienc Cuba. 2020;10(2). Spanish.

14. Yang Z, Zeng Z, Wang K, Wong S-S, Liang W, Zanin $\mathrm{M}$, et al. Modified SEIR and AI prediction of the epidemics trend of COVID-19 in China under public health interventions. J Thorac Dis. 2020;12(3):165-74.

15. Bizet NC, de Oca ACM. Modelos SIR modificados para la evolución del COVID19. ArXiv Prepr ArXiv200411352 [Internet]. 2020 Apr 23 [cited 2020 Jun 13]. Available at: https://arxiv . org/pdf/2004.11352

16. Verdasquera Corcho D, Ramos Valle I, Borroto Gutiérrez S, Rumbaut Castillo R, Pérez Ávila LJ, Berrio A, et al. Capacidad de respuesta y desafíos del sistema de salud cubano frente a las enfermedades transmisibles. Rev Panam Salud Pública [Internet]. 2018 Apr [cited 2020 Jun 10];42e30. Available at: https://iris.paho.org/ bitstream/handle/10665.2/34901/v42e302018 .pdf?sequence=3\&isAllowed=y. Spanish.
17. Granma. Cuba informa 40 medidas para el enfrentamiento al nuevo coronavirus Covid-19 Granma.cu [Internet]. 2020 Mar 24 [cited 2020 Aug 29]; [about 2 p.]. Available at: http:// www.granma.cu/cuba-covid-19/2020-03-24/ el-primer-secretario-del-pcc-y-el-presidenteactivaron-los-consejos-de-defensa-en-elpais-24-03-2020-01-03-10. Spanish.

18. Li C, Chen LJ, Chen X, Zhang M, Pang CP, Chen $\mathrm{H}$. Retrospective analysis of the possibility of predicting the COVID-19 outbreak from Internet searches and social media data, China, 2020. Eurosurveillance. 2020 Mar 12;25(10):1-5.

19. Arons MM, Hatfield KM, Reddy SC, Kimball A, James A, Jacobs JR, et al. Presyntomatic SAR-COV-2 infections and transmission in a skilled nursing facility. N Engl J Med. 2020 May 28;382(22):2081-90.

20. Oxford COVID-19 Government Response Tracker (OXCGRT) [Internet]. [place unknown]: HDX; c2020. Available at: https://data.humdata.org/m/ dataset/oxford-covid-19-government-responsetracker

21. Ministry of Public Health (CU). Pesquisador virtual COVID-19 [Internet]. Havana: Ministry of Public Health (CU); 2020 Apr [cited 2020 Jun 10]. Available at: autopesquisa.sld.cu. Spanish.

22. World Health Organization. Population-based age-stratified seroepidemiological investigation protocol for COVID-19 virus infection [Internet] Geneva: World Health Organization; 2020 Mar 17 [cited 2020 Apr 3]. Available at: https://apps .who.int/iris/rest/bitstreams/1273768/retrieve

23. Oxford COVID-19 Government Response Tracker (OXCGRT) [Internet]. [place unknown]: HDX; c2020. Available at: https://data.humdata.org/m/dataset/ oxford-covid-19-government-response-tracker

24. New cases of COVID-19 in World countries. Have countries flattened the curve? [Internet] Baltimore: Johns Hopkins Center for Systems Science and Engineering; [cited 2020 Jul 8].
Available at: https://coronavirus.jhu.edu/data/ new-cases

25. Castell-Florit Serrate P. "Universal" doesn't just apply to health care, but to every sector's actions taken to protect the population's health. MEDICC Rev [Internet]. 2020 Apr [cited 2020 Jun 5];22(2):21-3. Available at: https://mediccreview .org/universal-doesnt-just-apply-to-health-care -but-to-every-sectors-actions-taken-to-protect -the-populations-health/

\section{THE AUTHORS}

Enrique Galbán-García (Corresponding author: galban@infomed.sld.cu), physician specializing in epidemiology with a doctorate in public health, full and consulting professor, Medical University of Havana. Senior researcher, National Gastroenterology Institute., Havana, Cuba. https://ORCID .org/0000-0002-6010-224X

Pedro Más-Bermejo Epidemiologist with a doctorate in medical sciences and a higher doctorate in science, full and consulting professor, Medical University of Havana. Senior researcher, Pedro Kourí Tropical Medicine Institute, Havana, Cuba. https://orcid.org/0000 -0002-5350-657X

Submitted: May 15, 2020

Approved for publication: July 13, 2020 Disclosures: None 


\section{Characterization of Deaths from Cirrhosis of the Liver in Cuba, 1987-2017}

Plácido Pedroso-Flaquet MD PhD, Karen Alfonso-Sagué, Silvia J. Venero-Fernández MD MS PhD

\begin{abstract}
INTRODUCTION Cirrhosis of the liver is a chronic disease that is widespread and irreversible. It represents the final stage of numerous diseases that affect the liver. By the end of 2017, it was the 11th most common cause of death, with a loss of 41.4 million years of disability-adjusted life years, which represent $2.1 \%$ of the total years of life lost in the global mortality burden. In Cuba, cirrhosis and other chronic liver diseases have been among the top 10 causes of death for several decades, their rates consistently increasing, from 576 deaths in 1970 (6.7 per 100,000 population) to 1738 in 2017 (15.5 per 100,000 population), with a risk of death that is 4.6 times higher in men.
\end{abstract}

OBJECTIVE Characterize deaths from cirrhosis of the liver in Cuba from 1987 to 2017.

METHODS An ecological time-series study was conducted for 1987 to 2017 using information obtained from the mortality database of the Medical Records and Health Statistics Bureau of Cuba's Ministry of Public Health. The study universe consisted of all deceased persons in the country whose underlying cause of death was cirrhosis of the liver. Both general mortality rates and specific mortality were calculated by age group, sex and etiological classification using adjusted and crude rates. Rates were age-adjusted using the direct method, and the population from the 2002 Census of Population and Housing was considered as the standard population. Percentages and means were also calculated according to selected variables and the relative risk of death due to the disease according to sex, age group and etiological

\section{INTRODUCTION}

Liver cirrhosis (LC) is a chronic disease that is widespread and irreversible. It is characterized by fibrosis and formation of regenerative nodules that lead to alteration in the liver's vascular architecture and functionality. It represents the final stage of numerous diseases affecting the liver.[1]

LC is one of the world's main health problems due to its high morbidity and mortality rates. By the end of 2017 , it represented $2.4 \%$ of all deaths worldwide, approximately 1.35 million deaths. It was the 11th cause of death, with a loss of 41.4 million disability-adjusted life years, DALYs, which represent $2.1 \%$ of DALYs in the global mortality burden. LC is related to population growth and aging.[2,3] Different etiological factors are attributed to the prevalence of LC, including alcohol consumption, viral infections and morbid obesity, among others, distributed with wide variability between and within populations.

\section{IMPORTANCE}

This study characterizes mortality due to liver cirrhosis in Cuba (1987-2017), revealing an upward trend that is forecast to continue in coming years. The finding that nonalcoholic cirrhosis has the highest mortality rate suggests a need for more in-depth causality studies. classification. The trend and forecast for mortality rates were estimated for this disease.

RESULTS The crude mortality rate from cirrhosis of the liver was 9.0 per 100,000 population for the period. Those aged $\geq 75$ years had the highest risk of death (48.3 per 100,000 population). The crude and adjusted mortality rates were almost double for men (12.4 vs. 5.6 and 11.7 vs. 5.6 per 100,000 population, respectively), as was the total relative risk of death, which was 2.2 times higher. Nonalcoholic cirrhosis accounted for $71.6 \%$ of deaths. By the end of 2017 , risk of death from cirrhosis had climbed to 14.8 per 100,000 population (adjusted rate: 10.6 per 100,000 population), a signal that mortality had progressively increased over the 31 years analyzed. In addition, forecasts predict that death rates will continue their gradual increase, reaching 19.2 per 100,000 population in 2025 .

CONCLUSIONS Deaths from cirrhosis of the liver constitute a substantial health burden in Cuba. The upward trend and forecast, in addition to increased risk of mortality in men and older adults, are similar to those reported internationally. The finding that most of these deaths result from nonalcoholic cirrhosis should be further studied, as formulation of effective public health strategies depends largely on attaining a better understanding of the etiology, progression and social determinants of the disease.

KEYWORDS Liver cirrhosis, alcoholic liver cirrhosis, fatty liver, mortality, Cuba
In Western and high-income, industrialized countries, alcoholic and nonalcoholic fatty liver diseases are more prevalent than chronic viral hepatitis, while in China and other Asian countries, hepatitis B is more prevalent.[2] Cirrhosis primarily affects men and is common around the fourth or fifth decade of life; however, there are reports of cases in young adults and even in children.[1-3]

For several decades, cirrhosis and other chronic liver diseases have been among the top 10 causes of death in Cuba, deaths and mortality rates rising from 576 deaths in 1970 (6.7 per 100,000 population) to 1738 in 2017 (15.5 per 100,000 population), with a risk of death 4.6 times higher for men.[4,5]

The real magnitude of LC deaths in Cuba is unknown, which is why analyzing LC separately from the larger group of liver-disease deaths is an important step towards understanding its contribution to the mortality rate, data relevant for Cuban public health authorities.

The objective of this study was to characterize deaths due to LC from 1987 to 2017 in Cuba.

\section{METHODS}

We performed an ecological time-series study. The universe included all persons who had died from 1987 to 2017 whose primary cause of death on their death certificate was liver cirrhosis. 


\section{Study variables}

Sex Male, female.

Age Age in years at the time of death. The following age ranges were established: $0-14 ; 15-24 ; 25-39$; 40-49; 50-59; 60-74; $\geq 75$.

$L C$ classification The ninth and tenth revisions of the International Classification of Diseases (ICD-9, ICD10) were used to classify liver cirrhosis. $[6,7]$

- Alcoholic cirrhosis of the liver: Code 571.2 (ICD9 until 2000) and code K70.3 (ICD-10 since 2001).

- Nonalcoholic liver cirrhosis: Code 571.6 for biliary cirrhosis (ICD-9 until 2000) and codes K74.3, K74.4 y K74.5 for primary biliary cirrhosis, secondary biliary cirrhosis, and biliary cirrhosis, unspecified respectively (ICD-10 since 2001). For unspecified nonalcoholic cirrhosis: code 571.5 for cirrhosis of liver without mention of alcohol (ICD-9 until 2000) and K74.6 for other and unspecified cirrhosis of liver (ICD-10 since 2001).

Data collection, processing, and analysis We reviewed the mortality databases of the Ministry of Public Health's Bureau of Medical Records.[8] Population data was obtained from the National Statistics and Information Bureau (ONEI).[9]

We calculated crude and adjusted mortality rates, both global and specific to age group, sex and alcoholic or nonalcoholic etiology. The rates were adjusted for age using the direct method, and the standard population used was from Cuba's 2002 Population and Housing Census.[9] Means and percentages were also calculated according to the selected variables and the relative risk of death from LC according to sex, age group and type of LC.

An LC mortality rate for 2018-2025 was forecast using the two-parameter Holt-Winters model,[10] taking into account the annual frequency of the data. The model's goodness of fit was estimated using the mean square error and performing an analysis of residuals. Excel (Microsoft, USA) was used to develop a database to record results, presenting these in tables and figures.

Ethics The study was approved by the Research Ethics Committee of Cuba's National Institute of Hygiene, Epidemiology and Microbiology (INHEM). The Ministry of Public Health's Medical Records and Health Statistics Bureau authorized use of their data solely for research purposes.

\section{RESULTS}

Deaths due to LC by age group and sex During the period analyzed, there were 31,424 deaths due to LC, for an annual mean of 1014 deaths. The crude mortality rate was 9.0 per 100,000 population (adjusted rate: 8.6). The overall mean age at time of death was 63.0 years (SD 14.2); for men 61.0 years (SD 13.7) and for women, 67.2 years (SD 14.3). At the end of 2017, the risk of death was 14.8 per 100,000 population (adjusted rate: 10.6).

Mortality rates by age group showed a progressive increase with age. In descending order, the most deaths were in the $\geq 75$ group with a crude rate of 48.3 per 100,000 population (adjusted rate: 48.4 ), followed by the $60-74$ age group at 34.4 per 100,000 population (adjusted rate: 32.9 ) and finally the 50-59 age group at 19.4 per 100,000 population (adjusted rate: 18.6) (Table 1).

Men comprised $68.8 \%$ of deaths. The age groups contributing the highest number of deaths for men were the 60-74 and 50-59 age groups, with 7611 and 5515, respectively. These two groups accounted for $60.7 \%$ of deaths among men $(13,126 / 21,635)$. In women, the highest number of deaths occurred in the 60-74 (3933) and $\geq 75$ (3288) age groups, which represented $73.8 \%$ (7221/9789) of female deaths (Table 1).

The crude and adjusted mortality rates for the period were almost double for men, with 12.4 vs. 5.6 and 11.7 vs. 5.6 per 100,000 population respectively (Table 1 ). In men, there was a relative increase in crude mortality over the period of $242.2 \%$ (7.1 to 24.3 per 100,000 population); however, in women, there was a decrease of $3.7 \%$ (5.6 to 5.4 per 100,000 population) (Figure 1).

For both sexes, the risk of death also increased with age. The $\geq 75$ age group exhibited the highest mortality rate for both men and women (Table 1).

Deaths due to LC by etiology The highest risk corresponded to nonalcoholic LC, which accounted for $71.6 \%$ of deaths, while alcoholic LC accounted for $28.4 \%$ (Table 1 ).

The crude and adjusted mortality rates were higher for nonalcoholic cirrhosis (6.5 vs. 2.6 and 6.4 vs. 2.2 per 100,000 population, respectively) and the risk of death from both types of LC were higher among men (Table 1).

In men, mean age at time of death from alcoholic cirrhosis was 57.3 years (SD 11.9), lower than that for nonalcoholic cirrhosis (63.3 years; SD 14.3). In women, death from alcoholic cirrhosis also occurred at a younger age (59.8 years; SD 13.2) than among women with nonalcoholic cirrhosis (67.9 years; SD 14.2). 
Figure 1: Liver cirrhosis mortality rate by year and sex. Cuba, 1987-2017

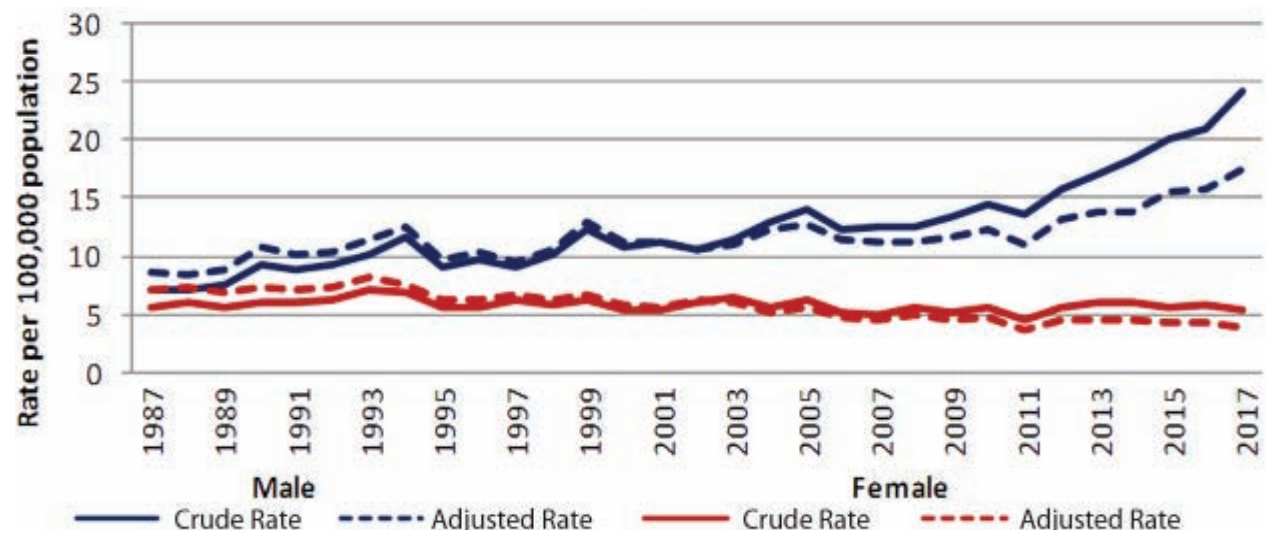

1987 to 14.8 by 2017 (Figure 2), for an increase of $131.2 \%$.

We forecast that LC mortality rates in Cuba will continue to rise gradually, reaching 19.2 (17.7-20.7) per 100,000 population in 2025 .

\section{DISCUSSION}

LC is the end result of a group of chronic liver diseases,[1] representing a major health problem due to the necessity of prolonged treatment and the fact that a liver transplant is, in some cases, the only effective therapy.[11,12]
Relative risk of death from LC in men by age group and disease etiology The relative risk of death from LC was 2.2 times higher in men than in women. Male sex was identified as a risk factor for death in all age groups and for both types of liver cirrhosis, except in persons $\leq 24$ years of age for both types of liver cirrhosis, when no difference was observed for risk of death between the sexes. For alcoholic cirrhosis, men's risk was 10.8 times higher than women's and age groups between 25 and 59 years were at higher risk. The relative risk of death for nonalcoholic cirrhosis was only 1.5 times higher in men than in women. In the 40-49 age group, men were 3.2 times more likely to die of nonalcoholic liver cirrhosis than women (Table 2).

LC mortality forecasting Mortality rates progressively increased during the 31 years analyzed. In terms of crude rates, LC mortality experienced an increase from 6.4 per 100,000 population in

Table 2: Relative risk of death from alcoholic and nonalcoholic liver cirrhosis in men by age group. Cuba, 1987-2017*

\begin{tabular}{|l|r|r|r|}
\hline & \multicolumn{2}{|c|}{ Type of cirrhosis } & \\
\hline Age group (in years) & Alcoholic & Nonalcoholic & Total \\
\hline $0-14$ & 0.0 & 0.7 & 0.7 \\
\hline $15-24$ & 0.0 & 0.9 & 1.0 \\
\hline $25-39$ & 11.5 & 2.3 & 3.5 \\
\hline $40-49$ & 12.4 & 3.2 & 5.2 \\
\hline $50-59$ & 12.1 & 2.3 & 3.6 \\
\hline $60-74$ & 10.7 & 1.4 & 1.9 \\
\hline$\geq 75$ & 6.1 & 1.0 & 1.2 \\
\hline Total & 10.8 & 1.5 & 2.2 \\
\hline
\end{tabular}

*women were used as a reference group

Figure 2: Liver cirrhosis mortality rate and forecast. Cuba, 1987-2025

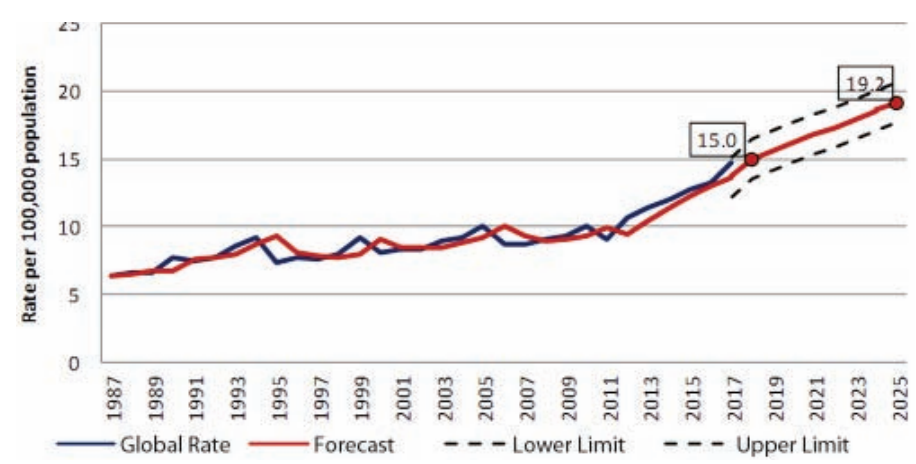

We could not compare the crude and adjusted mortality rates with other estimates, because the sources available only contained information for specific years. The risk of death in Cuba in 2017 was similar to forecasts released by international bodies and published epidemiological studies.[2,3,12] One recent study on burden of mortality, injuries and risk factors for LC predicted a standardized global mortality rate for 2017 of 16.5 (15.8-18.1) per 100,000 population, with a lower value in high-income countries (10.1 per 100,000 population) and a higher value in the broad region of Sub-Saharan Africa (32.2 per 100,000 population). In that study, Caribbean countries' predicted values were 10-20 per 100,000 population.[2]

The progressive increase in risk of death with age in both sexes was the expected result, as also found in other countries, evidenced by a recent systematic review.[2] In Cuba, characteristics of the Cuban health care system (universal, accessible, free of charge to patients), as well as newer medical treatments, may have contributed to this finding; these factors facilitate more timely diagnoses with proper care and followup, and consequently, greater chronicity and death at older ages.[11,13] Various studies conducted in different provinces of the country confirm this conjecture.[14-17] Cuba's quickly aging population[5] will undoubtably contribute to this increased risk.

The greatest risk of death in men is consistent with extensive medical literature at the national and international levels and can be explained by alcohol addiction.[1-3,14-20] In Barcelona and the United Kingdom, studies conducted in urban and rural areas demonstrate the presence of socioeconomic inequality in the male population with cirrhosis, which is correlated with low levels of education and socioeconomically disadvantaged areas, which in turn may be related to alcohol consumption.[18,19]

The main causes of LC are chronic consumption of alcohol and chronic viral disease, primarily from hepatitis $\mathrm{C}$ virus $(\mathrm{HCV})$ and hepatitis B virus (HBV), which taken together account for $90 \%$ of all cirrhosis cases.[1-3] In Cuba, the widespread prevalence of harmful alcohol use (5\%) and alcohol dependence (3\%) from 1995 to 2010 was similar to that of other countries, and these values have not changed over time.[18-22] Worldwide, half of LC deaths are attributed to alcoholism, with greater frequency among men. Therefore, in our study, it was surprising to find that nonalcoholic-LC causes were more prevalent in men, and that overall, 7 deaths in 10 corresponded to nonalcoholic cirrhosis.[2,3] 
Several national studies have identified infectious causes of LC in men, primarily HBV.[14,17] However, etiology of nonalcoholic cirrhosis can also be noninfectious.[1,2] In Cuba, various causes of nonalcoholic LC have been reported in different provinces,[14-17] which emphasizes the need for further research.

One factor that may influence the predominance of nonalcoholic LC in this population is obesity, which is recognized as a risk factor for nonalcoholic steatohepatitis (fatty liver disease) and consequent LC. From 2001 to 2010, Cuba experienced an increase in obesity prevalence (from $11.8 \%$ to $14.8 \%$ ). In addition, nonalcoholic fatty liver in advanced stages of the disease were reported in samples from liver biopsies.[20,23] Varying degrees of malnutrition observed in advanced stages of LC are also associated with its onset and prognosis.[24]

Regarding infection, universal vaccination against hepatitis B virus began in Cuba in 1992, with the application of a Cuban recombinant vaccine (Heberbiovac-HB). While over two decades separate this intervention from the end of our study period, it can still be assumed that a portion of LC deaths we found may have been from infections acquired before availability of vaccination.[25] Cuba has not been spared from the silent HCV epidemic that occurred from 1960 to 1989 , the year when the virus was identified.[26] There are no vaccines for $\mathrm{HCV}$, only treatments, which may cure up to $95 \%$ of cases, but which are expensive and have not been available in the entire Cuban health system. HCV infection has been identified as a public health problem in Cuba since 1990 after the first national serology study was conducted in blood banks, finding $0.8 \%$ positivity. This has increased to about $2 \%$, a value similar to global HCV prevalence $(2.3 \%)$ but higher than prevalence in the Caribbean as a whole (1.5\%).[3,27-29]

The increase in LC mortality rates over the course of the study period was an expected result, since reports from prior stud- ies in western and central Cuba had pointed to such a rise, and increased presence of important variables contributing to higher LC rates in the Cuban population were also recorded.[15,17,20] However, this finding was in contrast to global data,[2,3] which showed a decrease in LC mortality rates standardized by age in both sexes, the decrease more pronounced in men. Interventions to reduce alcohol and tobacco use, along with better treatments, have contributed to this trend.[2,3]

It would be expected that the trend of increasing LC in Cuba would continue if exposure to risk factors continues to increase. However, causality studies are needed to identify the social determinants with the greatest impact on the development of LC and its mortality rate in Cuba. Several studies on the burden of LC suggest that the causal factors with the greatest impact are those related to lifestyle (alcohol addiction and obesity) and infections, which may increase in the future in some countries. $[3,30]$

One important limitation of this study was the inability to break down nonalcoholic cirrhosis into different types to understand the incidence of each subtype.

\section{CONCLUSIONS}

Liver cirrhosis mortality represents a substantial health burden in Cuba and has increased since 1987. This increase is also evident in forecasts for the disease, especially for men and older adults, the latter a particularly important factor given the aging of the Cuban population. The predominance of nonalcoholic cirrhosis should be the object of future study.

\section{ACKNOWLEDGMENTS}

We would like to thank Dr Ramón Suárez-Medina for his contribution to the organization of the database. $-1 /$ -

\section{REFERENCES}

1. Ginés P, Arroyo V. Cirrosis hepática. In: Farre ras R, editor. Medicina Interna. 17th ed. Madrid Elsevier; 2012. p. 314-9. Spanish.

2. GBD 2017 Cirrhosis Collaborators. The global regional, and national burden of cirrhosis by cause in 195 countries and territories, 19902017: a systematic analysis for the Global Burden of Disease Study 2017. Lancet Gastroenterol Hepatol. 2020 Mar 1;5(3):245-66.

3. Asrani SK, Devarbhavi H, Eaton J, Kamath PS. Burden of liver diseases in the world. J Hepatol [Internet]. 2019 [cited 2020 Mar 11];70(1):151-71. Available at: https://www.journal-of-hepatology .eu/article/S0168-8278(18)32388-2/abstract

4. National Health Statistics and Medical Records Division (CU). Anuario Estadístico de Salud 1970. Havana: Ministry of Public Health (CU); 1970. Spanish.

5. National Health Statistics and Medical Records Division (CU). Anuario Estadístico de Salud 2017 [Internet]. Havana: Ministry of Public Health (CU); 2018 Apr [cited 2020 Mar 15]. 206 p. Available at: http://files.sld.cu/dne/files/2017/05/anua rio-2017-esp-e.pdf. Spanish.

6. Pan American Health Organization. Manual de la Clasificación Internacional de Enfermedades, Traumatismos, y Causas de Defunción CIE-9. Vol. 2 [Internet]. Washington, D.C.: Pan American Health Organization; 2003 [cited 2020 Mar 8]. 173 p. Available at: http://ais.paho.org/classifications/Chapters/pdf/ Volume2.pdf. Spanish.
7. Pan American Health Organization. Clasificación Estadística Internacional de Enfermedades y Problemas Relacionados con la Salud. Décima revisión. (CIE-10) Manual de Instrucciones. Décima revisión. Vol. 1. Washington, D.C.: Pan American Health Organization; 2003 [cited 2020 Mar 8]. 1177 p. Available at: https://iris.paho.org/ bitstream/handle/10665.2/6282/Volume1.pdf. Spanish.

8. INFOMED [Internet]. Havana: Ministry of Public Health (CU); c2020. Publicaciones. Health Care Situation in Cuba. Basic Indicators; [cited 2020 Mar 8]. Available at: https://temas.sld.cu/estadis ticassalud/publicaciones-2/health-care-situation -in-cuba-basic-indicators/. Spanish.

9. National Bureau of Statistics and Information (CU). Censo Nacional de Población y Viviendas. Havana:National Bureau of Statistics and Information (CU); 2002. Spanish.

10. Chatfield $\mathrm{C}$. The analysis of time series: an introduction. 6th ed. Florida: Chapman \& Hall; 2004.

11. Arús Soler E, Pérez Brioso NA, Parrilla Delgado M, Domínguez Álvarez C. Antifibrotic effect of recombinant interferon alfa $2 b$ in liver cirrhosis caused by virus B or C. Rev Cubana Med [Internet]. 2005 May-Aug [cited 2020 Mar 11]:44(34). Available at: http://scielo.sld.cu/scielo .php?script=sci_arttext\&pid=S0034-752320 05000400008\&lng=es. Spanish.

12. Ramírez-Soto M, Guevara-Cuadros J, HuichiAtamari M. Mortalidad por hepatocarcinoma y cirrosis hepática en Apurímac: 2007-2010. Rev
Perú Epidemiol [Internet]. 2012 Jan-Apr [cited 2017 Nov 12];16(1):1-5. Available at: http://www redalyc.org/pdf/2031/203124341008.pdf. Spanish.

13. Ojeda Morales R, Más Bermejo P, Castell-Florit Serrate P, Arocha Mariño C, Valdivia Onega NC, Druyet Castillo D, et al.. Transformaciones en el sistema de salud en Cuba y estrategias actuales para su consolidación y sostenibilidad. Rev Panam Salud Pública. 2018 Apr 24;42:e25. DOI: 10.26633/RPSP.2018.25. Spanish

14. Castellanos Suárez J, Infante Velázquez $M$ Pérez Lorenzo M, Umpiérrez García I, Fernández Báez A. Caracterización clínica de pacientes con cirrosis hepática en el Hospital Militar Docente Dr. Mario Muñoz, de Matanzas. Rev Méd Electrón [Internet]. 2012 Nov-Dec [cited 2020 Mar 16];34(6):624-37. Available at: http:// scielo.sld.cu/scielo.php?script=sci_arttext\&pid =S1684-18242012000600001. Spanish.

15. Fajardo González MH, Arce Núñez M, Medina Garrido Y, Esteva Carral L, Osorio Pagola MF. Comportamiento de la cirrosis hepática en el hospital "Arnaldo Milián Castro" de julio de 2007 a marzo de 2009. MediSur [Internet]. 2010 Jul-Aug [cited 2020 Feb 12];8(4):40-8. Available at: http://scielo .sld.cu/scielo.php?script=sci_arttext\&pid=S1727 -897X2010000400007. Spanish.

16. Roque Lozano JA, Sauchay Romero L, Rodríguez Chala HE. Caracterización de mortalidad por cirrosis hepática en el Hospital "Julio Trigo López”. 2012 a 2016. Rev Cubana Tecnol Salud [Internet]. 2019 Apr-Jun [cited 2020 Apr 
3];10(2):35-43. Available at: http://www.revtec nologia.sld.cu/index.php/tec/article/view/1310. Spanish.

17. Torreblanca Xiques A, Fonseca Chong L. Caracterización de los pacientes con cirrosis hepática atendidos en Las Tunas. Rev Electrón Dr. Zoilo Marinello [Internet]. 2014 [cited 2020 Mar 31];39(12). Available at: http://revzoilomarinello .sld.cu/index.php/zmv/article/view/121. Spanish.

18. Dalmau-Bueno A, García-Altés A, Mari-Dell'Olmo $M$, Pérez K, Espelt A, Kunst AE, et al. Trends in socio-economic inequalities in cirrhosis mortality in an urban area of Southern Europe: a multilevel approach. J Epidemiol Comm Health [Internet]. 2010 Aug [cited 2020 Mar 31];64(8):720-7. Available at: https://www.jstor.org/stable/40794069

19. Erskine S, Maheswaran R, Pearson T, Demrmot G. Socioeconomic deprivation, urban-rural location and alcohol-related mortality in England and Wales. BMC Pub Health [Internet]. 2010 Feb 25 [cited 2020 Feb 13];10:99. Available at: https://bmcpublichealth.biomedcentral.com/ar ticles/10.1186/1471-2458-10-99

20. Colectivo de autores. III Encuesta Nacional de Factores de Riesgo y Actividades Preventivas de Enfermedades No Transmisibles 2010-2011 [Internet]. Havana: Editorial Ciencias Médicas; 2014 [cited 2020 Mar 12]. Available at: https://especia lidades.sld.cu/higienepidemiologia/2014/08/23/ iii-encuesta-nacional-de-factores-de-riesgo-y -actividades-preventivas-de-enfermedades-no -trasmisibles-cuba-2010-2011/. Spanish.

21. World Health Organization. Informe Mundial de Situación sobre Alcohol y Salud 2018. Resumen. (OPS/NMH/19-012). Licencia: CC BY-NC-SA 3.0 IGO. Washington, D.C.: Pan American Health Organization; 2019. Spanish.

22. Rehm J, Samokhvalov AV, Shield KD. Global burden of alcoholic liver diseases. J Hepatol [Internet]. 2013 Jul 1 [cited 2020 Mar 8];59(1):160-8. Available at: https://www.journal-of-hepatology .eu/article/s0168-8278(13)00184-0/fulltext

23. Pérez Lorenzo $M$, Duarte Castillo $N$, Montero González T, Franco Estrada S, Winograd
Lay R, Brizuela Quintanilla RA. Prevalencia del hígado graso no alcohólico en muestras de biopsias hepáticas. Rev Cub Med Mil [Internet]. 2006 Oct-Dec [cited 2020 Mar 11];35(4). Available at: http://scielo.sld.cu/ scielo.php?script=sci arttext\&pid=S0138 $-65572006000400006 \&$ lng $=e s$. Spanish

24. Castellanos Fernández MI. La importancia de la desnutrición en el pronóstico del paciente con cirrosis hepática [thesis] [Internet]. [Havana]: Universidad de Ciencias Médicas de La Habana. Facultad de Ciencias Médicas "General Calixto García"; 2017 [cited 2020 Mar 8]. 156 p. Available at: http://tesis.sld.cu/index .php?P=FullRecord\&ID=391. Spanish

25. Pedroso Flaquet P. Aportes a la evaluación de la vacuna recombinante cubana contra la hepatitis B [thesis] [Internet]. [Havana]: "Pedro Kourí" Institute of Tropical Medicine (CU); 2009 [cited 2020 Mar 8]. 142 p. Available at: http://tesis.sld .cu/index.php?P=FullRecord\&ID=496. Spanish.

26. Lozano $R$, Naghavi $M$, Foreman $K$, Lim $S$, Shibuya K, Aboyans V, et al. Global and regional mortality from 235 causes of death for 20 age groups in 1990 and 2010: a systematic analysis for the Global Burden of Disease Study 2010. Lancet [Internet]. 2012 Dec 15 [cited 2020 Mar 8];380(9859):2095-128. Available at: https:// www.ncbi.nlm.nih.gov/pubmed/23245604

27. Padrón G, Arús E, Roca J, Viña A, Lemus G, Bacallao J. The hepatitis $C$ in Cuba: prevalence, antibody pattern, genotype and risk factor. Hepatology. 1994;19(4):141.

28. Vázquez Torres Y, Infante Velázquez M, Miranda Gómez O, Vázquez Torres YC, Vázquez Anovega $\mathrm{H}$, Torres Sánchez $\mathrm{C}$, et al. Detección de anticuerpos contra el virus de la hepatitis C en donantes de sangre voluntarios. Rev Cubana Med Gen Integr [Internet]. 2017 Oct-Dec [cited 2020 Apr 2];35(4). Available at: http://scielo.sld .cu/scielo.php?script=sci_arttext\&pid=S0864 $-21252017000400002 \&$ lng=es. Spanish.

29. Petruzziello A, Marigliano S, Loquercio G, Cozzolino A, Cacciapuoti C. Global epidemiology of hepatitis $C$ virus infection: an up-date of the distribution and circulation of hepatitis $\mathrm{C}$ virus genotypes. World J Gastroenterol [Internet]. 2016 Sep 14 [cited 2019 Nov 2];22(34):7824-40. Available at: https://www.ncbi.nlm.nih.gov/pmc/ articles/PMC5016383/

30. Younossi Z, Tacke F, Arrese M, Chander Sharma B, Mostafa I, Bugianesi E, et al. Global perspectives on nonalcoholic fatty liver disease and nonalcoholic steatohepatitis. Hepatology [Internet] 2019;69(6):2672-82. Available at: https://www .ncbi.nlm.nih.gov/pubmed/30179269

\section{THE AUTHORS}

Plácido Pedroso-Flaquet (Corresponding author: ppf@infomed.sld.cu), physician specializing in epidemiology with a doctorate in medical sciences. Full professor and senior researcher, Unit for Health Promotion and Disease Prevention (PROSALUD), Ministry of Public Health, Havana, Cuba. https://orcid.org/0000-0002 $-9340-7410$

Karen Alfonso-Sagué, mathematician, adjunct researcher, National Institute of Hygiene, Epidemiology and Microbiology (INHEM), Havana, Cuba. https://orcid.org/0000-0001-6621-013X

Silvia Josefina Venero-Fernández, physician specializing in family medicine and epidemiology, with a master's degree in environmental health and a doctorate in health sciences. Associate researcher and associate professor, INHEM, Havana, Cuba. https://orcid.org/0000 $-0002-5661-9043$

Submitted: December 2, 2019

Approved for publication: September 20, 2020 Disclosures: None 


\title{
Levels of Vitamins and Homocysteine in Older Adults with Alzheimer Disease or Mild Cognitive Impairment in Cuba
}

\author{
Yeneisy Lanyau-Domínguez MS PhD, Consuelo Macías-Matos MS PhD, Juan de Jesús Llibre-Rodríguez MD PhD DSc, \\ Gisela María Pita-Rodríguez MD MS, Ramón Suárez-Medina MD, María Eugenia Quintero-Alejo, \\ Lisseth Noriega-Fernández MD MS, Milagros Guerra-Hernández MD MS, Marina Calvo-Rodríguez MD MS, \\ Yvón Sánchez-Gil MD MS, Milagros García-Klibanski MD MS, Dania Herrera-Javier, Caridad Arocha-Oriol, \\ Maybe Díaz-Domínguez
}

\begin{abstract}
INTRODUCTION Age-related cognitive disorders, including Alzheimer disease, are among the main causes of disability and dependence in older adults worldwide. High blood homocysteine levels (hyperhomocysteinemia) are a risk factor for diseases whose metabolism involves different B vitamins. Antioxidant vitamins provide a protective effect by mitigating oxidative stress generated by these diseases. Epidemiological studies have presented varying results on the relationships between blood levels of these vitamins and such cognitive disorders.
\end{abstract}

OBJECTIVE Evaluate the association of vitamin and homocysteine levels with mild cognitive impairment and Alzheimer disease in a group of Cuban older adults.

METHODS A cross-sectional study was conducted in Havana, Cuba, of 424 persons aged $\geq 65$ years: 43 with Alzheimer disease, 131 with mild cognitive impairment, and 250 with no signs of cognitive impairment. Dementia was diagnosed using criteria of the International 10/66 Dementia Research Group and Diagnostic and Statistical Manual of Mental Disorders (DSM IV), and mild cognitive impairment was diagnosed using Petersen's criteria. Blood levels of vitamins (thiamine, B-2, folate, B-12, C and A) and homocysteine were measured by standard procedures. Analysis of variance for continuous variables and percentage comparison tests for dichotomous variables were used to compare groups.

\section{INTRODUCTION}

Dementia and its most common form, Alzheimer disease (AD), constitute one of the century's main health problems due to global population aging. These conditions are among the leading causes of disability and dependence in older adults around the world, with important implications for morbidity, quality of life, healthcare costs and mortality.[1,2] WHO estimated that some 50 million people suffered dementia in 2019 and that this figure will reach 82 million by 2030 , and 152 million by 2050 .[1]

$A D$ is characterized by progressive decline of cognitive functions and irreversible loss of neurons and their synapses, especially in the structures responsible for memory: the hippocampus and the cerebral cortex.[2] An estimated 170,000 Cubans suffered

\section{IMPORTANCE}

This is the first study in Cuba to examine vitamin and homocysteine levels in older adults with Alzheimer disease or mild cognitive impairment, and results show a relationship between these nutritional indicators and the cognitive disorders.
RESULTS Persons with Alzheimer disease presented significantly lower levels of vitamins B-2, C and A than healthy participants ( $p$ $<0.05$ ). Homocysteine levels were significantly higher in those with Alzheimer disease and mild cognitive impairment than in participants with no cognitive impairment $(p<0.05)$. Statistically, levels of thiamine, folic acid, and vitamin B-12 were not significantly different across groups. Compared with those without cognitive impairment, prevalence rates $(P R)$ in the Alzheimer group were significantly higher for hyperhomocysteinemia $(P R=3.26 ; 1.84-5.80)$ and deficiency of all $B$ vitamins: thiamine $(P R=1.89 ; 1.04-3.43), B-2(P R$ $=2.85 ; 1.54-5.26)$, folate $(P R=3.02 ; 1.53-5.95), B-12(P R=2.21$; 1.17-4.19), vitamin $C(P R=3.88 ; 2.12-7.10)$ and $A(P R=5.47$; 3.26-9.17). In mild cognitive impairment, prevalence rates were significantly higher for hyperhomocysteinemia $(P R=1.42 ; 1.08-1.87$ ), vitamin $B-2$ deficiency $(P R=1.70 ; 1.24-2.32)$ and vitamin $A$ deficiency $(P R=1.88 ; 1.05-3.38)$.

CONCLUSIONS Hyperhomocysteinemia and various vitamin deficiencies are related to Alzheimer disease and mild cognitive impairment. Longitudinal studies are needed to further elucidate the relationship between different nutritional biomarkers and dementia. A better understanding of this relationship could provide a basis for therapeutic and preventive strategies.

KEYWORDS Vitamins, homocysteine, geriatrics, Alzheimer disease, cognitive impairment, Cuba

from dementia in 2019, and it is estimated that this figure will have a $76 \%$ increase and reach 300,000 cases by 2040.[3] In recent years, dementia and $A D$ taken together have been the sixth leading cause of death in Cuba for both sexes.[4,5]

Another cognitive disorder of interest is mild cognitive impairment $(\mathrm{MCl})$, considered the gateway to dementia (proportion of conversion to dementia is $10 \%-15 \%$ of $\mathrm{MCl}$ persons annually). [6] $A D$ is an illness with multi-source etiology involving various factors, both genetic and environmental. From $1 \%$ to $5 \%$ of cases are hereditary. Risk factors include age (it is more common after age 65), sex (more commonly affects women), low educational and employment levels, depression, smoking, and genetic presence of the apolipoprotein epsilon 4 allele (APOE $\varepsilon 4$ ), especially in the case of homozygosity. Vascular risk factors (including hypertension, diabetes, hypercholesterolemia and obesity), heart disease, and stroke at mid-life increase the risk of vascular dementia and Alzheimer disease, while physical activity and healthy diet are protective factors. $[2,7,8]$

Homocysteine (Hcy) is a sulfur-containing amino acid that plays a crucial role in transfer of methyl groups in cellular metabolism. Its high levels present a risk factor for heart disease and stroke. In systematic reviews and meta-analyses of relevant epidemiological 
studies (mostly prospective and case-control), high plasma levels of Hcy represent a modifiable risk factor for cognitive dysfunction and AD.[9-11]

The B-group vitamins (B-2, B-6, folic acid, B-12) are involved in Hcy metabolism. Deficiencies in folate and vitamin B-12 (and to a lesser degree vitamin B-6) are associated with increased homocysteine levels in plasma; it has even been proposed that hyperhomocysteinemia be used as an indicator of these vitamin deficiencies.[10-13] Folic acid and vitamin B-12 intervene in cognitive activity through other functions. Folate deficiency affects synthesis of nuclear and mitochondrial DNA, causing neuronal deterioration and cellular death in areas of the brain involved in $A D$; this deficiency can lead to hypomethylation in regions that modulate expressions of genes presumably involved in $A D$ pathogenesis.[14,15] Vitamin B-12 also acts as a cofactor in the enzyme methylmalonyl-CoA mutase, and B-12 deficiency affects synthesis of fatty acids and can lead to cognitive impairment.[16]

Several epidemiological studies have examined the relation of $B$ vitamins and antioxidant levels with cognitive function and $A D$ risk, but results are inconclusive. $[8,16,17]$

In 2000, vitamin B deficiencies were found in Cuba's older adult population.[18] Some older adults' infrequent consumption of foods including proteins, vegetables, fruit and other poor dietary habits[19] may cause these deficiencies and may be related to their cognitive disorders. Our study's hypothesis is that vitamin deficiencies and Hcy are associated with cognitive impairment. This research aims to evaluate the relationship of homocysteine and vitamin levels with $\mathrm{MCl}$ and $\mathrm{AD}$ in older Cuban adults.

\section{METHODS}

Type of study and participants An analytical cross-sectional study was conducted in a randomly selected sub-sample of 174 individuals with cognitive impairment (131 with $\mathrm{MCl}$ and 43 with $A D$ ) and 250 individuals with no cognitive impairment from the prospective longitudinal Aging and Alzheimer Study. The Aging and Alzheimer Study launched in 2003 by the Medical University of Havana's Alzheimer Research Group, studied the disease in Cuban adults aged $\geq 65$ years. The participants reside in four health areas in Havana: Marianao (in the 27 de Noviembre and Carlos Manuel Portuondo Polyclinics), Lisa (Cristóbal Labra Polyclinic), 10 de Octubre (14 de Junio Polyclinic) and Playa (Ana Betancourt Polyclinic). Participants were recruited through family physicians in the respective health areas and the Cuban 10/66 Dementia Research Group. Clinical and biochemical evaluations were done for all 424 participants. Evaluators did not know the subjects' $\mathrm{MCl}$ or $\mathrm{AD}$ status.[20,21]

Inclusion criteria Older adults who gave their written consent to participate.

Exclusion criteria Presentation of the following disorders: intestinal malabsorption, cancer, hepatic diseases, chronic kidney disease, decompensated diabetes mellitus or any other condition indicating cognitive impairment such as epilepsy, psychiatric disorders of the psychotic type or intellectual disability, cranial fracture, encephalic vascular event (thrombosis, ischemia, stroke) or other type of dementia.
Variables Table 1 presents a summary of variables.

Clinical evaluation for $\mathrm{MCl}$ and $\mathrm{AD}$ diagnosis We used the tools developed by the Cuban 10/66 Dementia Research Group, including a questionnaire on sociodemographic features, health status, lifestyle and risk factors.[20] Dementia was diagnosed using the international 10/66 criteria and algorithm, validated in 26 countries (including Cuba),[20] which includes:

- Clinical interview structured on the study participant's mental state analyzed through a computerized algorithm (AGECAT)[22]

- Interview with a reliable informant (CSI-D RELSCORE)[23]

- Community dementia screening tool (CSI-D COGSCORE)[23]

- Test for verbal fluency and repetition of CERAD modified-words list (10 words)[24]

- Additional information on early dementia and its development according to information provided by the 10/66 dementia diagnostic algorithm, its sub-types, history and etiology[25]

DSM-IV criteria[26] of the American Psychiatric Association were also used to diagnose dementia. $\mathrm{MCl}$ was diagnosed using Petersen's criteria.[27]

Clinical evaluations were conducted by medical specialists in the Medical University of Havana's Alzheimer Research Group, who received prior training based on earlier studies. Evaluation results were used to classify participants in three groups: those with $\mathrm{MCl}$, persons with $A D$, and those with no cognitive impairment.

Biochemical evaluation Samples of approximately $20 \mathrm{~mL}$ of blood were extracted intravenously after fasting; one aliquot was collected without anticoagulant and one aliquot in tubes containing ethylenediaminetetraacetic acid (EDTA). Table 1 presents the cutoff points used for the different biochemical variables. All techniques were performed in compliance with the respective quality control standards.

A volume of $0.5 \mathrm{~mL}$ of plasma plus anticoagulant was treated with an equal volume of metaphosphoric acid and frozen to $-80{ }^{\circ} \mathrm{C}$ for determination of vitamin $C$ by spectrophotometry.[30] Other aliquots of plasma were used to quantify homocysteine through the enzymatic oxidation of NADH to NAD+,[29] with a commercial diagnostic kit C02257/3 (C.P.M. Diagnostic Research SAS, Italy). Vitamin A was quantified in an aliquot of plasma by high-resolution liquid chromatography.[31]

Vitamin B-2 levels were calculated by stimulating the enzyme glutathione reductase in erythrocytes obtained after plasma separation.[32] Vitamin B-1 and B-2 levels were measured by determining the effect of thiamine pyrophosphate[33] and the activation coefficient of the enzyme glutathione reductase through the activities of transketolase and erythrocyte glutathione reductase activity coefficient (EGRAC)[32] respectively; these enzymes are indirect indicators of the availability of circulating vitamins since enzymatic activity increases due to deficiency in levels of both vitamins.

Serum obtained by centrifuging the blood without anticoagulant was conserved at $-20^{\circ} \mathrm{C}$. Quantification of serum folate and vitamin B-12[34] was determined through electrochemiluminescence immunoassay using commercial diagnostic kits (Roche Diagnostics Gmb, Germany). 
Table 1: Study variables

\begin{tabular}{|c|c|c|}
\hline VARIABLE & INDICATOR & CRITERIA \\
\hline \multicolumn{3}{|l|}{ Cognitive } \\
\hline Diagnosis of $A D$ & $\begin{array}{l}\text { 10/66 diagnosis criteria and } \\
\text { algorithm[22-25]- DSM-IV } \\
\text { criteria[26] }\end{array}$ & If criteria are met \\
\hline Diagnosis of $\mathrm{MCl}$ & Petersen's criteria ${ }^{1}[27]$ & If criteria are met \\
\hline \multicolumn{3}{|c|}{ Sociodemographic category } \\
\hline Sex & Female, male & \\
\hline Age & Years & \\
\hline Skin color & white, mestizo, Black & \\
\hline $\begin{array}{l}\text { Educational level } \\
\text { completed }\end{array}$ & $\begin{array}{l}\text { None; or primary, secondary } \\
\text { or university level completed }\end{array}$ & \\
\hline
\end{tabular}

Lifestyle

Smoking behavior Smoker or ex-smoker

Number of cigarettes, cigars, or

\begin{tabular}{|c|c|c|}
\hline $\begin{array}{l}\text { Alcoholic beverage } \\
\text { consumption }\end{array}$ & Risky (heavy) drinker & $\begin{array}{l}\text { If weekly alcohol consumption } \geq 14 \\
\text { units for women or } \geq 21 \text { for men }{ }^{2}[20]\end{array}$ \\
\hline \multicolumn{3}{|c|}{ Clinical exam and interview } \\
\hline Hypertension & $\begin{array}{l}\text { Self-reported and blood } \\
\text { pressure measurements }\end{array}$ & $\begin{array}{l}\text { Systolic pressure } \geq 140 \mathrm{mmHg} \text { and/ } \\
\text { or diastolic pressure } \geq 90 \mathrm{mmHg}[20]\end{array}$ \\
\hline Diabetes mellitus & $\begin{array}{l}\text { Self-reported and fasting } \\
\text { blood glucose }\end{array}$ & $\begin{array}{l}\text { Fasting blood glucose } \geq 7.0 \\
\mathrm{mmol} / \mathrm{L}[20]\end{array}$ \\
\hline $\begin{array}{l}\text { Family history of } \\
\text { dementia }\end{array}$ & Self-reported & If affirmative[20] \\
\hline \multicolumn{3}{|l|}{ Biochemical } \\
\hline Vitamin B-1 & TPPE $^{3}$ & $\begin{array}{ll}\text { Normal } & \text { TPPE } \leq 15 \% \\
\text { Marginal } & 15<\text { TPPE } \leq 25 \% \\
\text { Deficient } & \text { TPPE }>25 \%[28]\end{array}$ \\
\hline Vitamin B- 2 & EGRAC $^{3}$ & $\begin{array}{ll}\text { Normal } & E G R A C \leq 1.30 \\
\text { Marginal } & 1.30<E G R A C<1.80 \\
\text { Deficient } & E G R A C \geq 1.80[28]\end{array}$ \\
\hline Vitamin C & Vitamin C level & $\begin{array}{ll}\text { Normal } & >0.3 \mathrm{mg} / \mathrm{dL} \\
\text { Marginal } & 0.2-0.3 \mathrm{mg} / \mathrm{dL} \\
\text { Deficient } & <0.2 \mathrm{mg} / \mathrm{dL}[28]\end{array}$ \\
\hline Vitamin A & Retinol level & $\begin{array}{ll}\text { Low } & 20 \leq \mathrm{RL} \leq 30 \mu \mathrm{g} / \mathrm{dL} \\
\text { Marginal } & 10 \leq \mathrm{RL}<20 \mu \mathrm{g} / \mathrm{dL} \\
\text { Deficient } & \mathrm{RL}<10 \mu \mathrm{g} / \mathrm{dL}[28]\end{array}$ \\
\hline Serum folate & Serum folate level & Deficient $<3.1 \mathrm{ng} / \mathrm{mL}[28]$ \\
\hline Vitamin B-12 & Vitamin B-12 level & Deficient <240 pg/mL[28] \\
\hline Homocysteine & Homocysteine level & Homocysteine $>15 \mu \mathrm{mol} / \mathrm{L}[29]$ \\
\hline
\end{tabular}

AD: Alzheimer disease:

MCI: Mild cognitive impairment;

RL: Retinol level;

EGRAC: Erythrocyte glutathione reductase activation coefficient. Based on calculation of the degree of stimulation of erythrocyte glutathione reductase through parallel measurement of enzymatic activity with in vitro addition of its coenzyme flavin adenine dinucleotide (stimulated activity of the enzyme) and without the coenzyme (basal enzymatic activity).

TPPE: Thiamine pyrophosphate effect. Based on calculation of degree of transketolase enzyme stimulation through parallel measurement of enzymatic activity with addition of its coenzyme in vitro thiamine

pyrophosphate (TPP) (activity stimulated by the enzyme) and without the coenzyme (basal enzymatic activity).

${ }^{1}$ Criteria developed by Petersen;[27] presence of:

a) Subjective memory complaints

b) Pathological performance in neuropsychological tests

c) No interference of memory impairment in subject's work / social / daily life

d) Remaining cognitive functions preserved

e) Absence of dementia

f) Absence of other pathologies that could explain memory impairment (depression, endocrine disease, etc.)

${ }^{2}$ Units of alcohol established according to beverage type: 1 glass of beer ( $250 \mathrm{~mL}=2$ units), 1 shot of liquor

$(22 \mathrm{~mL}=2$ units $)$ or 1 glass of wine $(175 \mathrm{~mL}=2$ units $)$ and 1 bottle of liquor $(1000 \mathrm{~mL}=32$ units $)$.

${ }^{3}$ Increases in TPPE and EGRAC lead to greater deficiencies in Vitamin B-1 and B-2 levels, respectively.
Due to insufficient sample volume, we quantified serum folate, B-12 and thiamine in $92 \%$ of the samples; vitamin B-2 in $89 \%$; vitamin $\mathrm{C}$ in $91 \%$; homocysteine in $90 \%$; and vitamin $\mathrm{A}$ in $81 \%$ of the samples.

Ethical considerations The study's protocol was approved by the Scientific Council and Research Ethics Committee of the National Hygiene, Epidemiology and Microbiology Institute and the Medical University of Havana. The study was conducted in accordance with the World Medical Association's Declaration of Helsinki and its ethical principles for medical research involving human subjects.[35] The scientific and social features and importance were explained to all participants and family members representing them, and their oral and written consent was obtained. In the case of older adults unable to give their consent, approval was sought from the family member responsible for their care.

Data processing and analysis Means and standard deviations were calculated to describe quantifiable variables and absolute frequencies and percentages for qualitative variables. An analysis of covariance was applied to identify the main or interactive effects of covariables (age and family history of dementia, which differed across groups) on vitamin means; none were determined to be significant $(p>0.05)$.

To compare the three groups $(A D, M C l$, and without cognitive impairment), a one-way analysis of variance was conducted, with a posteriori tests to identify different groups using parametric tests or their non-parametric alternatives depending on whether they met the assumptions of group normality and homoscedasticity. A significance level of $p=0.05$ was adopted. The test of homogeneity between groups was applied to the biochemical variables. The Pearson correlation was calculated as a measure of linear association of homocysteine levels with folate, vitamins $\mathrm{B}-12$ and $\mathrm{B}-2$. The prevalence of hyperhomocysteinemia was calculated as well as the prevalence of vitamin deficiencies, taking as reference the group with no cognitive impairment (with confidence intervals estimated at 95\%). The statistical procedure used SPSS Statistics version 20 software (IBM, USA).

\section{RESULTS}

The average age was 78 years old in the group with no cognitive impairment, 79.5 in the $\mathrm{MCl}$ group and 82.8 in the $A D$ group. 
Table 2: Sociodemographic and clinical features of participants

\begin{tabular}{|c|c|c|c|}
\hline \multirow[t]{2}{*}{ Feature } & $\begin{array}{c}\text { No cognitive } \\
\text { impairment } \\
n=250\end{array}$ & $\begin{array}{c}\text { Mild cognitive } \\
\text { impairment } \\
n=131\end{array}$ & $\begin{array}{c}\text { Alzheimer } \\
\text { disease } \\
n=43\end{array}$ \\
\hline & $\mathbf{N}(\%)$ & N (\%) & $\mathbf{N}(\%)$ \\
\hline \multicolumn{4}{|l|}{ Sex } \\
\hline Male & $78(31.2)$ & $46(35.1)$ & $12(27.9)$ \\
\hline Female & $172(68.8)$ & $85(64.9)$ & $31(72.1)$ \\
\hline \multicolumn{4}{|l|}{ Age group (years) } \\
\hline $65-69$ & $2(0.8)$ & $0(0)$ & $0(0)$ \\
\hline $70-74$ & $76(30.4)$ & $30(22.9)$ & $4(9.3)$ \\
\hline $75-79$ & $83(33.2)$ & $41(31.3)$ & $13(30.2)$ \\
\hline$\geq 80$ & $89(35.6)$ & $60(45.8)$ & $26(60.5)$ \\
\hline \multicolumn{4}{|l|}{ Skin color } \\
\hline White & $174(69.6)$ & $88(67.2)$ & $30(69.8)$ \\
\hline Mestizo & $32(12.8)$ & $11(8.4)$ & $6(14.0)$ \\
\hline Black & $44(17.6)$ & $32(24.4)$ & $7(16.3)$ \\
\hline \multicolumn{4}{|c|}{ Educational level completed } \\
\hline $\begin{array}{l}\text { None or incomplete } \\
\text { primary }\end{array}$ & $64(25.6)$ & $32(24.4)$ & $17(39.5)$ \\
\hline Primary & $86(34.4)$ & $50(38.2)$ & $8(18.6)$ \\
\hline Secondary & $47(18.8)$ & $26(19.8)$ & $8(18.6)$ \\
\hline University & $53(21.2)$ & $23(17.6)$ & $10(23.3)$ \\
\hline \multicolumn{4}{|l|}{ Smoking behavior } \\
\hline $\begin{array}{l}\text { Smoker or ex- } \\
\text { smoker }\end{array}$ & $116(46.6)$ & $63(48.1)$ & $20(46.5)$ \\
\hline Non-smoker & $133(53.4)$ & 68 (51.9) & $23(53.5)$ \\
\hline \multicolumn{4}{|c|}{ Alcohol consumption } \\
\hline Yes & $7(2.8)$ & $2(1.6)$ & $4(9.3)$ \\
\hline No & $242(97.2)$ & $126(98.4)$ & $39(90.7)$ \\
\hline \multicolumn{4}{|l|}{ Hypertension } \\
\hline Yes & $183(73.2)$ & $98(74.8)$ & $31(72.1)$ \\
\hline No & $67(26.8)$ & $33(25.2)$ & $12(27.9)$ \\
\hline \multicolumn{4}{|c|}{ Glucose metabolism disorder } \\
\hline Yes & $121(49.8)$ & $72(55.4)$ & $24(58.5)$ \\
\hline No & $122(50.2)$ & $58(44.6)$ & $17(41.5)$ \\
\hline \multicolumn{4}{|c|}{ Family history of dementia } \\
\hline Yes & $28(11.2)$ & $21(16.0)$ & $11(25.6)$ \\
\hline No & $222(88.8)$ & $110(84.0)$ & $32(74.4)$ \\
\hline
\end{tabular}

$\mathrm{N}$ : Number of persons $\quad \mathrm{n}$ : number of persons evaluated. $\%: 100 \times \mathrm{N} / \mathrm{n}$.

Other sociodemographic and clinical features were similar across groups, except family history of dementia, which was more common in the groups with cognitive disorders. In all three groups, $60 \%$ of participants had a low education level (elementary school only), $47 \%$ were smokers or ex-smokers, only $3 \%$ drank alcohol, $73 \%$ had hypertension and $52 \%$ had altered glucose (Table 2).

Hcy levels varied notably across groups. The highest levels were found in the $A D$ group and $\mathrm{MCl}$ group. Only those with $A D$ had notably lower levels of vitamins $\mathrm{C}, \mathrm{A}$, and $\mathrm{B}-12$. No differences were found across the groups in levels of thiamine (B-1), folate and vitamin B-12. Vitamins B-1 and B-2 levels were lower in the most severe cases of $A D$ and $\mathrm{MCl}$. The average vitamin $\mathrm{C}$ level was lower in the AD group than in the $\mathrm{MCl}$ group (Table 3).
The prevalence of vitamin deficiency in B-2, folate, C, A and hyperhomocysteinemia were significantly more common in individuals with $A D$ than in individuals with no cognitive impairment. Vitamins B-1 and B-12 deficiencies showed the same pattern but were not statistically significant (Table 4).

For all biochemical markers, prevalence rates were higher than one and notably higher in the $\mathrm{AD}$ group than in the $\mathrm{MCl}$ group, with the exception of folate (Table 5).

\section{DISCUSSION}

The B vitamins (B-2, B-6, folic acid, B-12) are involved in Hcy metabolism. High levels of this compound are considered a risk factor for cardiovascular disease, stroke, and more recently, Alzheimer disease and vascular dementia. Deficiency of B-group vitamins, the leading cause of hyperhomocysteinemia in older adults, is influenced mainly by diet.[11-13,36]

This study confirmed that Hcy levels were significantly higher in individuals with $\mathrm{AD}$ and $\mathrm{MCl}$ and that hyperhomocysteinemia was more common in $\mathrm{MCl}$ and $\mathrm{AD}$ than in participants with no cognitive impairment. High Hcy levels are associated with cognitive impairment and AD.[10-13,36] In 17 of the 19 cohort studies included in a systematic review that evaluated the relationship between Hcy levels and AD risk, a significant association was found.[10] A meta-analysis of 68 studies confirmed that persons with $A D$ had higher levels of Hcy than those without cognitive impairment, suggesting that higher Hcy levels could be an AD risk factor.[11]

Several mechanisms have been proposed to explain the relation between Hcy and AD, including demethylation, cerebrovascular damage, oxidative stress and high levels of the ß-amyloid peptide.[9,12,36,37] Deficiencies of the vitamin B group can lead to insufficient methylation of Hcy and therefore, reduced synthesis of methionine and S-adenosylmethionine. This in turn can lead to a shortage of methyl groups that are essential for the synthesis of nucleic acids, proteins, neurotransmitters, membrane phospholipids and for metabolism of myelin, which could affect reduction of neurocognitive function. $[8,9,38]$

Excess Hcy has a detrimental effect on blood vessel walls, since the oxidation of its sulfhydryl group generates potential reactive forms, such as superoxide anions, hydrogen peroxide and hydroxyl anion, which can cause endothelial damage. The endothelial cells reduce synthesis of nitric oxide, leading to vasoconstriction and increased platelet stickiness, lipoprotein oxidation and with that, increased LDL deposits on arterial walls, activation of the coagulation cascade and limitation of blood flow, resulting in thrombosis and neuronal death.[9,12]

High Hcy levels reportedly can have a neurotoxic effect by stimulating the glutamate receptor that induces increased calcium flow to the cell's interior. As a result, neuronal toxicity from oxidative stress is amplified, leading finally to apoptosis.[9,12,37]

The increased content of oxygen radicals due to high Hcy levels can also lead to hydrolysis of the precursor protein amyloid, increased generation of the $\beta$-amyloid peptide, and formation of amyloid plaques in the neurons (one of the main characteristics of Alzheimer disease).[8,32] 
Table 3: Average homocysteine and vitamin levels in older adults by degree of cognitive impairment

\begin{tabular}{|c|c|c|c|c|}
\hline $\begin{array}{l}\text { Biochemical } \\
\text { indicator } \\
\mathbf{n}\end{array}$ & $\begin{array}{c}\text { No cognitive } \\
\text { impairment } \bar{X} \text { (SD) } \\
n=250\end{array}$ & $\begin{array}{c}\text { Mild cognitive } \\
\text { impairment } \bar{X}(S D) \\
n=131\end{array}$ & $\begin{array}{c}\text { Alzheimer } \\
\text { disease } \bar{X}(S D) \\
n=43\end{array}$ & p \\
\hline $\begin{array}{l}\text { Homocysteine }(\mu \mathrm{mol} / \mathrm{L}) \\
380\end{array}$ & $\begin{array}{r}13.6^{\mathrm{a}}(6.5) \\
\mathrm{n}=214\end{array}$ & $\begin{array}{r}14.6^{\mathrm{b}}(5.7) \\
\mathrm{n}=126\end{array}$ & $\begin{array}{r}18.0^{c}(7.7) \\
n=40\end{array}$ & 0.000 \\
\hline $\begin{array}{l}\text { Vitamin B-1 (TPPE) \% } \\
379\end{array}$ & $\begin{array}{r}12.8(12.2) \\
\mathrm{n}=214\end{array}$ & $\begin{array}{r}13.2(12.4) \\
n=126\end{array}$ & $\begin{array}{r}19.6(18.6) \\
n=39\end{array}$ & 0.320 \\
\hline $\begin{array}{l}\text { Vitamin B-2 (EGRAC) } \\
372\end{array}$ & $\begin{array}{r}1.16^{\mathrm{a}}(0.12) \\
\mathrm{n}=215\end{array}$ & $\begin{array}{r}1.19^{\mathrm{ab}}(0.14) \\
\mathrm{n}=120\end{array}$ & $\begin{array}{r}1.23^{b}(0.17) \\
n=37\end{array}$ & 0.027 \\
\hline $\begin{array}{l}\text { Serum folate }(\mathrm{ng} / \mathrm{mL}) \\
391\end{array}$ & $\begin{array}{r}10.6(5.1) \\
n=228\end{array}$ & $\begin{array}{r}10.3(5.1) \\
n=126\end{array}$ & $\begin{array}{r}9.2(5.8) \\
\mathrm{n}=37\end{array}$ & 0.250 \\
\hline $\begin{array}{l}\text { Vitamin B-12 (pg/mL) } \\
391\end{array}$ & $\begin{array}{r}575.3(419.3) \\
\mathrm{n}=228\end{array}$ & $\begin{array}{r}564.3(421.3) \\
n=126\end{array}$ & $\begin{array}{r}581.5(543.2) \\
\mathrm{n}=37\end{array}$ & 0.440 \\
\hline $\begin{array}{l}\text { Vitamin C }(\mu \mathrm{mol} / \mathrm{L}) \\
386\end{array}$ & $\begin{array}{r}79.1^{\text {a }}(64.0) \\
n=226\end{array}$ & $\begin{array}{r}75.5^{\mathrm{a}}(45.6) \\
\mathrm{n}=122\end{array}$ & $\begin{array}{r}61.6^{b}(51.9) \\
n=38\end{array}$ & 0.043 \\
\hline $\begin{array}{l}\text { Vitamin } \mathrm{A}(\mu \mathrm{g} / \mathrm{dL}) \\
345\end{array}$ & $\begin{array}{r}65.5^{a}(20.6) \\
n=197\end{array}$ & $\begin{array}{r}63.2^{\mathrm{ab}}(21.8) \\
\mathrm{n}=111\end{array}$ & $\begin{array}{r}55.3^{b}(23.3) \\
n=37\end{array}$ & 0.039 \\
\hline
\end{tabular}

n: Number of persons evaluated; $\bar{X}$ : mean; SD: Standard deviation; TPPE: Effect of thiamine pyrophosphate in the transketolase enzyme indicator of vitamin B-1. A higher value indicates lower availability of the vitamin; EGRAC: Erythrocyte glutathione reductase activation coefficient, a biochemical indicator of vitamin: a higher value indicates lower availability of the vitamin.

a, b, ab, $\mathrm{c}$ Indicates differences between average values of the Scheffé test a posteriori for parametric analysis and the Kruskal Wallis test as a non-parametric alternative: matching letters indicate similarities and different letters indicate differences.

Table 4: Hyperhomocysteinemia and vitamin deficiency in older adults by degree of cognitive impairment

\begin{tabular}{|c|c|c|c|c|}
\hline Biochemical indicator & $\begin{array}{c}\text { No cognitive } \\
\text { impairment } \\
\text { N (\%) } \\
\text { n }\end{array}$ & $\begin{array}{c}\text { Mild cognitive } \\
\text { impairment } \\
\text { N (\%) } \\
\text { n }\end{array}$ & $\begin{array}{c}\text { Alzheimer } \\
\text { disease } \\
\mathbf{N}(\%) \\
\mathbf{n}\end{array}$ & $\begin{array}{l}X^{2} \\
(p)\end{array}$ \\
\hline $\begin{array}{l}\text { Hyperhomocysteinemia } \\
(>15 \mu \mathrm{mol} / \mathrm{L})\end{array}$ & $\begin{array}{r}56(26.2) \\
\mathrm{n}=214\end{array}$ & $\begin{array}{r}49(38.9) \\
\mathrm{n}=126\end{array}$ & $\begin{array}{r}24(60.0) \\
n=40\end{array}$ & $\begin{array}{r}18.7 \\
(0.000)\end{array}$ \\
\hline $\begin{array}{l}\text { Vitamin B-1 deficiency } \\
\text { (TPPE >15\%) }\end{array}$ & $\begin{array}{l}92(43) \\
\mathrm{n}=214\end{array}$ & $\begin{array}{r}61(48.4) \\
\mathrm{n}=126\end{array}$ & $\begin{array}{r}24(61.5) \\
n=39\end{array}$ & $\begin{array}{r}4.8 \\
(0.091)\end{array}$ \\
\hline $\begin{array}{l}\text { Vitamin B-2 deficiency } \\
(\text { EGRAC >1.30) }\end{array}$ & $\begin{array}{l}19(8.8) \\
n=215\end{array}$ & $\begin{array}{r}24(20.0) \\
\mathrm{n}=120\end{array}$ & $\begin{array}{r}10(27.0) \\
\mathrm{n}=37\end{array}$ & $\begin{array}{r}12.9 \\
(0.002)\end{array}$ \\
\hline $\begin{array}{l}\text { Folate deficiency } \\
(<3.10 \mathrm{ng} / \mathrm{mL})\end{array}$ & $\begin{array}{l}12(5.3) \\
n=228\end{array}$ & $\begin{array}{r}4(3.2) \\
\mathrm{n}=126\end{array}$ & $\begin{array}{r}7(18.9) \\
\mathrm{n}=37\end{array}$ & $\begin{array}{r}9.6 \\
(0.008)\end{array}$ \\
\hline $\begin{array}{l}\text { Vitamin B-12 deficiency } \\
\text { (<240 pg/mL) }\end{array}$ & $\begin{array}{r}28(12.3) \\
\mathrm{n}=228\end{array}$ & $\begin{array}{r}19(15.1) \\
\mathrm{n}=126\end{array}$ & $\begin{array}{r}10(27.0) \\
\mathrm{n}=37\end{array}$ & $\begin{array}{r}4.88 \\
(0.087)\end{array}$ \\
\hline $\begin{array}{l}\text { Vitamin C deficiency } \\
(<11 \mu \mathrm{mol} / \mathrm{L})\end{array}$ & $\begin{array}{r}9(4.0) \\
\mathrm{n}=226\end{array}$ & $\begin{array}{r}5(4.1) \\
\mathrm{n}=122\end{array}$ & $\begin{array}{r}8(21.1) \\
n=38\end{array}$ & $\begin{array}{r}12.3 \\
(0.002)\end{array}$ \\
\hline $\begin{array}{l}\text { Vitamin A deficiency } \\
(<1.05 \mu \mathrm{mol} / \mathrm{L})\end{array}$ & $\begin{array}{r}2(1.0) \\
n=197\end{array}$ & $\begin{array}{r}4(3.6) \\
n=111\end{array}$ & $\begin{array}{r}6(16.2) \\
n=37\end{array}$ & $\begin{array}{r}14.6 \\
(0.001)\end{array}$ \\
\hline
\end{tabular}

$\mathrm{N}$ : Number of persons with the value of the biochemical indicator; $\mathrm{n}$ : number of persons evaluated; $\%: 100$ $x \mathrm{~N} / \mathrm{n}$.

TPPE: Thiamine pyrophosphate effect on transketolase enzyme EGRAC: Erythrocyte glutathione reductase activation coefficient. Values of $p$ calculated by the chi-square test of homogeneity.

Independent of high Hcy levels, folic acid and vitamin B-12 also contribute to cognitive function.[14-16] Folate deficiency affects nuclear and mitochondrial DNA synthesis due to lack of methylation of purines, and impedes transformation of uracil into thymine, causing oxidative stress and generation of reactive oxygen species, followed by neuronal deterioration and cellular death in areas of the brain involved in AD.[14,15] Folate deficiency can also cause hypomethylation of regions that modulate expression of genes presumably involved in AD pathogenesis. $[14,15]$ In addition, vitamin B-12 is a cofactor of the enzyme methylmalonyl-CoA mutase; deficiency of this vitamin causes inactivation of the enzyme and accumulation of methylmalonyl-CoA, affecting fatty- acid synthesis. Cognitive impairment results from accumulation of abnormal fatty acids in neural tissue membranes.[16]

Results of several authors vary with respect to these vitamin levels in older adults with and without AD. A 30-study meta-analysis showed that plasma levels of these vitamins were significantly lower in persons with AD.[39] Another meta-analysis (of 68 studies) found that those with $A D$ had higher homocysteine levels and lower serum folate and vitamin B-12 levels in plasma than those found in persons without AD.[11] In line with our study, two other cross-sectional studies did not find significant differences in average serum folate and vitamin B-12 levels across the groups.[40,41]

We found that serum folate and Vitamin B-12 deficiencies were more prevalent in the $A D$ group, similar to several other epidemiological studies. $[13,42,43]$

Although some studies (particularly those using a cross-sectional design) have shown association, and despite the large number of cohort studies, there is still insufficient evidence to conclude an association between folate or vitamin B-12 levels and risk of cognitive impairment and dementia, as shown in the differing results in the literature. $[8,11,16]$ This is likely due to a variety of different study designs in terms of sample size, duration, lack of control for confounding variables and use of more specific biological markers, among other factors.

Vitamin B-2 plays a crucial role. Its co-enzymatic form (flavin-adenine dinucleotide, FAD) acts as a co-factor of the enzyme methylenetetrahydrofolate reductase, which metabolizes the folate participating in Hcy methylation.[8,9] A South Korean study in elders divided into three groups (normal individuals, those with $\mathrm{MCl}$ and those with $A D$ ) found that Hcy levels were inversely proportional to intake of vitamins B-2, B-6, B-12 and folate. Among $A D$ subjects, those with higher vitamin intake presented better results on several tests: the Mini-Mental State Examination-KC, CERAD-K Consortium (MMSE-KC), Boston Naming Test, Word Fluency, Word List Memory Test and Constructional Recall Test.[44] In the MCI group, those with higher vitamin B-2 intake presented better results on the MMSE-KC and Boston Naming tests.[44] These results show that vitamin B-2 is important in cognitive function.

In our research, vitamin B-1 levels were lower in individuals with $\mathrm{MCl}$ and even lower in those with $\mathrm{AD}$. Although differences in $B-1$ levels across groups were not significant, individuals with $A D$ showed greater prevalence of B-1 deficiency.

Vitamin B-1 apparently plays a role in AD pathogenesis.[45,46] AD patients reportedly have lower vitamin B-1 levels in plasma and 
Table 5: Hyperhomocysteinemia and vitamin deficiency in older adults with mild cognitive impairment and Alzheimer disease

\begin{tabular}{|l|c|c|}
$\begin{array}{l}\text { Biochemical } \\
\text { indicator }\end{array}$ & $\begin{array}{c}\text { Mild cognitive } \\
\text { impairment } \\
\text { PR (CI) }\end{array}$ & $\begin{array}{c}\text { Alzheimer } \\
\text { disease } \\
\text { PR (CI) }\end{array}$ \\
\hline Hyperhomocysteinemia & $1.42(1.08-1.87)$ & $3.26(1.84-5.80)$ \\
\hline Vitamin B-1 deficiency & $1.15(0.87-1.51)$ & $1.89(1.04-3.43)$ \\
\hline Vitamin B-2 deficiency & $1.70(1.24-2.32)$ & $2.85(1.54-5.26)$ \\
\hline Folate deficiency & $0.69(0.29-1.64)$ & $3.02(1.53-5.95)$ \\
\hline Vitamin B-12 deficiency & $1.16(0.79-1.70)$ & $2.21(1.17-4.19)$ \\
\hline Vitamin C deficiency & $1.02(0.50-2.09)$ & $3.88(2.12-7.10)$ \\
\hline Vitamin A deficiency & $1.88(1.05-3.38)$ & $5.47(3.26-9.17)$ \\
\hline
\end{tabular}

$\mathrm{Cl}$ : Confidence interval; PR: Prevalence rate; PR were calculated using individuals with no cognitive impairment as a reference group.

reduced vitamin-B-dependent activity of enzymes $\alpha$-ketoglutarate dehydrogenase and $\alpha$-transketolase in their brains and peripheral tissue.[45,46] In rats with vitamin B-1 deficiency, accumulation of the amyloid precursor protein has been observed in damaged brain regions; this provokes accumulation of the $\beta$-amyloid peptide that forms amyloid plaques, the main cause of neuronal death.[45]

Vitamin B-1 requires synthesis of acetylcholine, the neurotransmitter most commonly deficient in AD. Reduced acetylcholine synthesis has been observed in brains of rats with vitamin B-1 deficiency.[44] Multiple events are associated with vitamin B-1 deficiency. One of these is reduced activity of $\alpha$-ketoglutarate dehydrogenase, which leads to an energy deficit due to deterioration of the tricarboxylic acid cycle and reduced ATP synthesis, in addition to decreased activity of the $\mathrm{Na}^{+} / \mathrm{K}^{+}-$ATPase, resulting in high toxicity, activation of glutamate receptor, calcium input, and finally, neuronal death.[46]

Findings show that vitamin B-1 deficiency is tied to neuroinflammation, which plays a key role in $A D$ pathogenesis. When B-1 supply is deficient, reports indicate morphological glial-cell alterations, including swelling and appearance of phagocytic vacuoles; proinflammatory cytokines are also produced in vulnerable and non-vulnerable regions of the brain.[45] In animals with vitamin B-1 deficiency, increased reactive oxygen species, induction of the endothelial isoform of nitric oxide synthase and changes in superoxide dismutase levels have all been reported.[45]

Our study's results also show that plasma levels of antioxidant vitamins $C$ and $A$ were significantly lower in the $A D$ group than in those with no cognitive impairment. Vitamin A deficiency was much more common in individuals with $\mathrm{MCl}$-and especially those with $A D$ - than in those with no cognitive impairment, while vitamin $C$ deficiency occurred in individuals with $A D$. A metaanalysis of studies on eight vitamins showed that persons with $A D$ had significantly lower levels of vitamin $C, E$ and $A$ than those without cognitive impairment.[39] A cross-sectional study of older adults in Germany found significantly lower levels of vitamin C and $\beta$-carotene in individuals with dementia than in the healthy individuals.[17] Another more recent meta-analysis of studies on vitamin levels in cerebrospinal fluid showed that persons with $A D$ had significantly lower vitamin C, E, folate and B-12 levels.[47]

Other findings in studies on rats show that vitamin $C$ reduces generation of the $\beta$-amyloid peptide and acetylcholinesterase activity. Vitamin $C$ prevents endothelial impairment, one of the main factors in $\mathrm{AD}$ pathogenesis and progression.[48]

Recent in vitro studies have shown that vitamin A (retinol, retinal and retinoic acid) and the $\beta$-carotene provitamin inhibit the formation, extension and destabilization of $\beta$-amyloid peptide fibrils. Vitamin $A$ and $\beta$-carotene in vitro have an inhibitory effect on oligomerization of the two main types of the $\beta$-amyloid peptide, $A \beta 40$ and $A \beta 42$ (the last one is prominent in the brains of individuals with AD).[49]

In cognitive disorders, availability of antioxidant vitamins decreases, due to oxidative stress. Neural membranes are a potential target for oxidative stress damage due to their high content of polyunsaturated fatty acids vulnerable to oxidation. Lipid peroxidation can alter the membrane's composition, which is evident in Alzheimer disease. Vitamins A, C and $E$ serve as antioxidants to protect lipid precursors and membrane components against lipid peroxidation. In $A D$, the need for vitamins increases in order to compensate for their increased use.[39,47]

In this study, low levels of vitamins B-2, C and A were found in patients with $A D$ and $\mathrm{MCl}$, in line with results from other authors.[10,11,39,47] It is not possible to infer causation in these associations or even potential reciprocal causation: that is, dementia as a factor that promotes poor nutritional intake, or, inversely, the process of dementia as a result of reduced nutritional intake in older adults.[39]

One study limitation is that its cross-sectional design does not allow chronological ordering of events to be established, or, as a result, whether the nutritional indicators associated with $\mathrm{MCl}$ and $\mathrm{AD}$ can be determined to be the cause of the disease or merely a consequence of it. Due to limited resources, more specific biological markers were not used. The study's results are important because this is the first time cognitive disorders in older Cubans have been studied in relation to vitamin deficiency and hyperhomocysteinemia. Longitudinal studies are needed to further understand the relationship between different nutritional biomarkers and dementia.

\section{CONCLUSIONS}

The association of certain vitamin deficiencies and hyperhomocysteinemia with mild cognitive impairment and Alzheimer disease was confirmed in older adults in Cuba. Both these results and a range of epidemiological evidence support the close relationship between nutrition and $A D$ in Cuba's older adult population.

\section{ACKNOWLEDGMENTS}

We want to thank $\mathrm{Dr}$ Josanne Soto Matos of the Hermanos Ameijeiras Clinical-Surgical Teaching Hospital for her quantification of folic acid and vitamin B-12.

\section{FINANCING}

The study received financing from Cuba's Ministry of Public Health and the Aging and Alzheimer Project (10/66 study), the latter a collaboration between the Medical University of Havana and the Institute of Psychiatry, Psychology and Neurosciences of King's College, London, financed by Welcome Trust (GR066133) and Cuba's Ministry of Public Health. - 1 - 


\section{REFERENCES}

1. World Health Organization [Internet]. Geneva: World Health Organization; c2019. Centro de prensa. Notas descriptivas. Demencia; 2019 Sep [cited 2019 Nov 10]; [about 4 screens]. Available at: https://www.who.int/es/news-room/fact -sheets/detail/dementia. Spanish.

2. Lane CA, Hardy J, Schott JM. Alzheimer's disease. Eur J Neurol. 2018;25(1):59-70.

3. Reymond AG, Gispert EA, Llibre JJ, CastellFlorit P, Bosch R I, Llerena T. Percepción de las demencias y la intersectorialidad en el contexto del Policlínico Docente Playa. Rev Cubana Salud Pública. 2019;45(1):e1128. Spanish

4. National Health Statistics and Medical Records Division (CU). Anuario Estadístico de Salud 2017 (Table 19). Havana: Ministry of Public Health (CU); 2018 Apr [cited 2020 Jun 2]. 206 p. Available at: https://files.sld.cu/dne /files/2018/04/Anuario-Electronico-Espa \%c3\%b1ol-2017-ed-2018.pdf. Spanish.

5. National Health Statistics and Medical Records Division (CU). Anuario Estadístico de Salud 2018 (Table 19) [Internet]. Havana: Ministry of Public Health (CU); 2019 May [cited 2020 Jun 2]. 206 p. Available at: https://files.sld.cu/bvs cuba/files/2019/04/Anuario-Electr\%c3\%b3nico -Espa\%c3\%b1ol-2018-ed-2019-compressed.pdf Spanish.

6. Vega JN, Newhouse PA. Mild cognitive impairment: diagnosis, longitudinal course, and emerging treatments. Curr Psychiatry Rep. 2014 Oct;16(10):490. DOI: 10.1007/s11920 $-014-0490-8$.

7. Prince $M$, Albanese $E$, Guerchet $M$, Prina M. Alzheimer's Disease International. World Alzheimer Report 2014. Dementia and risk reduction. An analysis of protective and modifiable factors. London: Alzheimer's Disease International; 2014

8. Prina M, Albanese E. Nutritional factors and dementia prevention. In: Prince M, Albanese E, Guerchet M, Prina M, editors. Nutrition and Dementia: a review of available research. London: Alzheimer's Disease International; 2014. p. 31-42.

9. Smith D, Refsum H. Homocysteine, B Vitamins, and cognitive impairment. Annu Rev Nutr. 2016;36:211-39.

10. Beydoun MA, Beydoun HA, Gamaldo AA, Teel A, Zonderman AB, Wang Y. Epidemiologic studies of modifiable factors associated with cognition and dementia: systematic review and meta-analysis. BMC Public Health. 2014 Jun 24;14:643

11. Shen L, Ji H. Associations between homocysteine, folic acid, vitamin B12 and Alzheimer's disease: insights from meta-analyses. J Alzheimers Dis. 2015;46(3):777-90.

12. Zaric B, Obradovic $M$, Bajic V, Haidara $M$, Jovanovic $M$, Isenovic $E$. Homocysteine and hyperhomocysteinaemia. Curr Med Chem. 2019;26(16):2948-61.

13. Baroni L, Bonetto C, Rizzo G, Bertola C, Caberlotto L, Bazzerla G. Asocciation between cognitive impairment and vitamin B12, folate, and homocysteine status in elderly adults: a retrospective study. J Alzheimer's Dis. 2019 Jul 23;70(2):443-53.

14. Robinson N, Grabowski P, Rehman I. Alzhemer's disease pathogenesis: is there a role for folate? Mech Ageing Dev. 2018 Sep;174:86-94

15. Araújo JR, Martel F, Borges N, Araújo JM, Keating $\mathrm{E}$. Folates and aging: role in mild cognitive impairment, dementia and depression. Ageing Res Rev. 2015 May;22:9-19.

16. O'Leary F, Allman M, Samman S. Vitamin B12 status, cognitive impairment and dementia: a systematic review of prospective cohort studies. British J Nutr. 2012 Dec 14;108(11):194861
17. von Arnim CA, Herbolsheimer F, Nikolaus T, Peter R, Biesalski HK, Ludolph AC, et al. Dietary antioxidants and dementia in a populationbased case-control study among older people in South Germany. J Alzheimers Dis. 2011 Dec 31;31(4):717-24

18. Lanyau Domínguez $\mathrm{Y}$, Hernández $\mathrm{M}$, Macías Matos C, Zhou D. Is B vitamins deficiency associated with prevalence of Alzheimer's disease in Cuban elderly? Nutr Health. 2006 Jan 1;18(2):103-18.

19. Gónzález L. Reforma económica en Cuba: mecanismos de desigualdad social y su repercusión en las personas de la Tercera Edad. INFOHEM. 2016;14(2):20-7. Spanish.

20. Llibre Rodríguez JJ, Valhuerdi Cepero A, Calvo M, García RM, Guerra M, Laucerique T, et al Dementia and other chronic diseases in older adults in Havana and Matanzas: The 10/66 study in Cuba. MEDICC Rev. 2011 Oct;13(4):30-7.

21. Llibre Rodríguez JJ, Valhuerdi Cepero A, López Medina AM, Noriega Fernández L, Porto Álvarez R, Guerra Hernández MA, et al. Cuba's aging and Alzheimer longitudinal study. MEDICC Rev. 2017 Jan;19(1):31-5.

22. Copeland JR, Dewey ME, Griffith-Jones HM. A computerized psychiatric diagnostic system and case nomenclature for elderly subjects: GMS and AGECAT. Psychol Med. 1986 Jan 31;16(1):89-99.

23. Hall KS, Hendrie $\mathrm{HH}$, Brittain HM, Norton JA, Rodgers DD, Prince CS, et al. The development of a dementia screening interview in two distinct languages. Int J Methods Psychiatric Res. 1993;3:1-28.

24. Ganguli M, Chandra V, Gilbey JE, Ratcliff G, Sharma SD, Pandav R, et al. Cognitive test performance in a community-based non demented elderly sample in rural India: the Indo-US cross national dementia epidemiology study. Int Psychogeriatr. 1996 Winter;8(4):507-24.

25. Dewey ME, Copeland JR. Diagnosis of dementia from the history and aetiology schedule. Int J Geriatr Psychiatry. 2001 Sep;16(9):912-7.

26. American Psychiatric Association. Diagnostic and Statistical Manual of Mental Disorders. 4th ed. Washington, D.C.: American Psychiatry Association; 1994 Jan 15. 886 p.

27. Petersen RC, Stevens JC, Ganguli M, Tangalos EG, Cummings JL, Dekosky ST. Practice parameter: Early detection of dementia: Mild cognitive impairment (an evidence- based review). Report of the Quality Standards Subcommittee of the American Academy Neurology. Neurology. 2001 May 8;56(9):1133-42.

28. Van Den Berg $H$, Heseker $H$, Lamand $M$, Sandstrom B, Thurnham D. Flair Concerted Action No 10 Status Papers. Int J Vit Nutr Res. 1993;63:247-316.

29. Ueland PM, Refsum H, Stabler SP, Malinow MR, Andersson A, Allen RH. Total homocysteine in plasma or serum: methods and clinical applications. Clin Chem. 1993;39(9):1764-79.

30. Interdepartmental Committee on Nutrition for National Defense; National Institutes of Health. Serum Vitamin C (Ascorbic Acid)-Dinitrophenyl hydrazine method. In: Manual for Nutrition Surveys. 2 nd ed. Washington, D.C.: Interdepartmental Committee on Nutrition for National Defense; 1963. p. $117-9$

31. Thurnham DI, Smith E, Flora PS. Current LiquidChromatographic assay of retinol, alfa-tocopherol, beta-carotene, alpha-carotene, lycopene, and beta-cryptoxantin in plasma with tocopherol acetate as internal standard. Clin Chem. 1988;43:377-81.

32. Fidanza F. Nutritional Status Assessment. A manual for population studies. New York: Chapman \& Hall; 1991. p. 228-309.
33. Basu TK, Patel DR, Williams DC. A simplified microassay of transketolase in human blood. Int J Vit Res. 1974;44:319-26.

34. Selhub J, Jacques PF, Dallal G, Choumenkovitch $\mathrm{S}$, Rogers $\mathrm{G}$. The use of blood concentrations of vitamins and their respective functional indicators to define folate and vitamin B12 status. Food \& Nutr Bull. 2008;29:567-73.

35. World Medical Association [Internet]. FerneyVoltaire (FR): World Medical Association; c2020. Políticas. Políticas actuales. Declaración de Helsinki de la Asociación Médica Mundial. Principios éticos para las investigaciones médicas en seres humanos; 2017 Mar 21 [cited 2012 Nov 18]. Available at: https://www.wma.net/es/ policies-post/declaracion-de-helsinki-de-la-amm -principios-eticos-para-las-investigaciones-medi cas-en-seres-humanos/. Spanish.

36. Smith D, Refsum $\mathrm{H}$, Bottiglieri $\mathrm{T}$, Fenech $\mathrm{M}$, Hooshmand B, McCaddon A, et al. Homocysteine and Dementia: An International Consensus Statement. J Alzheimer's Dis. 2018;62:561-70.

37. Sharma M, Tiwart M, Kumar RK. Hyperhomocysteinemia: impact on neurodegenerative diseases. Basis \& Clin Pharmacol \& Toxicol. 2015;117(5):287-96.

38. Porter K, Hoey L, Hughes C, Ward M, McNulty $\mathrm{H}$. Causes, consequences and public health. Implications of low B-Vitamin status in ageing. Nutrients. 2016;8:725 DOI: 10.3390

39. Lopes da Silva S, Vellas B, Elemans S, Luchsinger J, Kamphuis P, Yaffe K, et al. Plasma nutrient status of patients with Alzheimer's disease: systematic review and meta-analysis. Alzheimer's \& Dementia. 2013:1-18.

40. Kim G, Kim H, Kim KN, Son JI, Kim SY, Tamura $\mathrm{T}$, et al. Relationship of cognitive function with B vitamin status, homocysteine, and tissue factor pathway inhibitor in cognitively impaired elderly: a cross sectional survey. J Alzheimers Dis. 2013;33(3):853-62.

41. Faux N, Ellis K, Porter L, Fowler C, Laws S, Martins $\mathrm{R}$, et al. Homocysteine, vitamin B12, and Folic acid levels in Alzheimer's disease, Mild Cognitive Impairment, and Healthy elderly: baseline characteristics in subjects of the Australian Imaging Biomarker Lifestyle study. J Alzheimer's Dis. 2011;27(4):909-22.

42. Ma F, Wu T, Zhao J, Ji L, Song A, Zhang M, et al. Plasma homocysteine and serum folate and vitamin B12 levels in Mild Cognitive Impairment and Alzheimer's Disease: a case-control study. Nutrients. 2017;9(7):pii:E725. DOI:10.3390/ nu9070725

43. Meng H, Li Y, Zhang W, Zhao Y, Niu X, Guo J. The relationship between cognitive impairment and homocysteine in a B12 and folate deficient population in China: a cross- sectional study. Medicine (Baltimore). 2019;98(47):el7970.

44. Hyesook K, Ggotpin K, Wong J, Seong Y, Namsoo C. Association between intake of $B$ vitamins and cognitive function ibn elderly Koreans with cognitive impairment. Nutrition $\mathrm{J}$. 2014;13:118

45. Vinhquoc $K$, Thi Hoáng $L$. Role of Thiamine in Alzheimer's Disease. Am J Alzheimer's Dis \& Other Dementias. 2011;26 (8):588-98.

46. Hazell A, Faim S, Wertheimer G, Silva V, Marques $C$. The impact of oxidative stress in thiamine deficiency: a multifactorial targeting issue. Neurochem Int. 2013;62:796-802.

47. de Wilde M, Vellas B, Girault E, Cetinyurek Yavuz A, Sijben JW. Lower brain and blood nutrient status in Alzheimer's disease: results from meta-analyses. Alzheimer Dement. 2017 Sep;3(3):416-31.

48. Hyeok J, Lee $\mathrm{H}$, Min Lee $\mathrm{K}$. The possible role of antioxidant vitamin C in Alzheimer's disease 
treatment and prevention. Am J Alzheimer's Dis \& Other Dementias. 2013;28(2):120-5.

49. Ono K, Yamada M. Vitamin A and Alzheimer's disease. Geriatr Gerontol. 2012;12:180-8.

\section{THE AUTHORS}

Yeneisy Lanyau-Domínguez (Corresponding author: ylanyau@infomed.sld.cu, yeneisy@inhem .sld.cu), biochemist with a master's degree in nutrition sciences and public health, and a doctorate in health sciences. Associate researcher, Biochemistry and Physiology Department, Nutrition and Food Hygiene Center (CNHA) of the National Hygiene, Epidemiology and Microbiology Institute (INHEM), Havana, Cuba. https:// orcid.org/0000-0002-1900-9852

Consuelo Macías-Matos, biochemist with a master's degree in nutrition sciences and public health, and a doctorate in chemistry. Senior researcher, Biochemistry and Physiology Department, CNHA, INHEM, Havana, Cuba. https://orcid.org/0000-0002-0241-7294

Juan de Jesús Llibre-Rodríguez, internist with a doctorate in medical sciences and a higher doctorate in science. Full professor and senior researcher, Alzheimer Research Center, Finlay Albarrán Faculty of Medicine, Medical University of Havana, Cuba. https://orcid .org/0000-0002-8215-3160
Gisela María Pita-Rodríguez, physician specializing in clinical biochemistry with a master's degree in environmental health. Associate researcher and associate professor, Biochemistry and Physiology Department, CNHA, INHEM, Havana, Cuba. https://orcid.org/0000-0002-5590-2461

Ramón Suárez-Medina, physician specializing in biostatistics. Associate researcher and associate professor, Epidemiology and Environmental Health Department, INHEM, Havana, Cuba. https://orcid.org/0000-0002-5311-5237

María Eugenia Quintero-Alejo, laboratory technician, Biochemistry and Physiology Department, CNHA, INHEM, Havana, Cuba. https://orcid.org/0000-0002-1093-6035

Lisseth Noriega-Fernández, psychiatrist with a master's degree in healthy longevity. Instructor, Marianao Community Mental Health Center, Havana, Cuba. https://orcid.org/0000-0003 $-3560-8625$

Milagros Guerra-Hernández, psychiatrist with a master's degree in healthy longevity. Assistant professor, 27 de Noviembre Polyclinic, Havana, Cuba. https://orcid.org/0000-0002-6835-1742

Marina Calvo-Rodríguez, psychiatrist with a master's degree in health psychology. Instruc- tor, La Lisa Community Health Center, Havana, Cuba.

Yvón Sánchez-Gil, psychiatrist with a master's degree in longevity studies. Assistant professor, Ana Betancourt Polyclinic, Havana, Cuba.

Milagros García-Klibanski, psychiatrist with a master's in social psychiatry. Full professor, Luyanó Polyclinic, Havana, Cuba.

Dania Herrera-Javier, laboratory technician, Biochemistry and Physiology Department, CNHA, INHEM, Havana, Cuba. https://orcid .org/0000-0002-0245-0879

Caridad Arocha-Oriol, laboratory technician, Biochemistry and Physiology Department, CNHA, INHEM, Havana, Cuba. https://orcid .org/0000-0001-5519-4592

Maybe Díaz-Domínguez, laboratory technician, Biochemistry and Physiology Department, CNHA, INHEM, Havana, Cuba. https://orcid .org/0000-0002-3199-2407

Submitted: June 26, 2020

Approved for Publication: September 9, 2020 Disclosures: None 


\title{
Determination of Reference Values for Double-Negative $\mathrm{T}$ Lymphocytes in Cuban Adults
}

\author{
Carlos A. Villegas-Valverde MD MS, Elena Kokuina MD PhD, Martha C. Breff-Fonseca MD
}

\begin{abstract}
INTRODUCTION Double-negative T lymphocytes act as immunomodulators in immune response. This subpopulation is rare in blood but important in the immunopathogenesis of autoimmune diseases, viral infections, cancer and transplant rejection. These disorders have been studied in Cuba using flow cytometry, but normal values of these cells have not yet been established.
\end{abstract}

OBJECTIVE Estimate preliminary reference values for doublenegative $\mathrm{T}$ lymphocytes according to sex and age in Cuban adults.

METHODS A cross-sectional study was carried out in a population of 182 healthy adult residents of Havana: 93 women and 89 men aged 18-80 years with no chronic diseases, toxic habits (smoking, excessive alcohol or caffeine intake) or medications that might alter quantity or functioning of immune-system cells. Peripheral blood was drawn to determine immunophenotype with monoclonal antibodies. The phenotype of double-negative $T$ lymphocytes was quantified as $\mathrm{CD}^{+} 5^{+} / \mathrm{CD}^{+} / \mathrm{CD} 4 / \mathrm{CD} 8 / \mathrm{CD} 56$ - using a Gallios flow cytometer (Beckman-Coulter, France). Medians and ranges (to the 5th and 95th percentiles) were calculated for sex and age, for both percentages and absolute values. To evaluate the effects of sex and age, both variables as well as their interaction were included in a linear model.

\section{INTRODUCTION}

Flow cytometry has enabled study of lymphocyte populations and their heterogeneity. In lymphocyte phenotyping, two types of classical T-lymphocyte populations (TCD4+ and TCD8+) were initially reported. These were considered as two unique, mutually exclusive T-cell subpopulations, since early cytometry allowed for only two or three simultaneous markings on a single cell.[1] The TCD3+ lymphocytes that do not express markers CD4 and CD8 are known as "double-negative" T cells (DNT cells). They were recently discovered and are characterized by a mature immunophenotype (CD45 $\left./ \mathrm{CD}^{+} / \mathrm{CD} 4 / \mathrm{CD} 8 / \mathrm{CD} 56\right)$ and express clonotypic T-cell receptors (CTR) of type $\alpha \beta$ or type $\gamma \delta$. These cells are found in greater proportion in the blood and lymph nodes, although they reportedly account for $3 \%-7 \%$ of total lymphocytes in peripheral blood.[2-5]

The physiological functions of DNT lymphocytes are not yet fully understood. The immunomodulation attributed to them is based on their ability to suppress the functions of simple positive $\mathrm{T}$ cells and their cytotoxicity for tumor cells and cells infected

IMPORTANCE Normal values of double-negative T lymphocytes in Cuban adults are useful for studying immunesystem diseases, cancer and transplant rejection and for avoiding subregistration when using flow cytometry to analyze T, B and NK cells.
RESULTS Respective median and range values were total percentage values 3.4 (1.6-7.4) and total absolute values (cells/ $\mu \mathrm{L}) 57.5$ (23.0-157.0). The effect of age on lymphocyte values (percentage and absolute) was significant, with lower numbers in the $51-80$ years' age group $(p<0.001)$. Percentage values according to age group were: $18-25$ years, 3.8 (2.27.4); 26-50 years, 3.7 (1.7-8.7); and 51-80 years $2.6(1.3-6.6)$. Absolute values by age group were: $18-25$ years, 90 (32.6-163.7); $26-50$ years, 65 (28.8-184.0); and 51-80 years 38.5 (17.9-90.1). Desegregating data by sex and age: percentage of women aged 18-25 years 5.2 (2.1-7.8), $26-50$ years $4.0(1.8-7.7)$, and $51-80$ years 2.5 (1.3-5.8); percentage of men aged $18-25$ years 3.4 (2.3-7.3), 26-50 years 3.8 (1.5-8.7), and $51-80$ years $2.6(1.2-7.3)$. Absolute values: women aged $18-25$ years 112.0 (40.0-153.1), 26-50 years 67.0 (26.7-138.3), and 51-80 years 40 (18.6-92.0); and men aged 18-25 years 71.5 (32.1-166.7), 26-50 years 61.5 (29.9-188.7), and 51-80 years 36 (13.5-81.7). The low sex*age interaction confirms these differences occur in both men and women. Values decrease with age, with a more abrupt fall starting at 50 years.

CONCLUSIONS Estimated reference values were determined for absolute values and relative proportions of double-negative $T$ lymphocytes in healthy Cuban adults according to sex and age. Age was found to have a significant effect.

KEYWORDS Reference values, T lymphocytes, flow cytometry, immunology, Cuba

by viruses.[2,3] In some immune-system diseases, variations were found in total numbers of DNT lymphocytes or their functions were altered. Although only small quantities of these lymphocytes are found in blood, they play an important role in various diseases' immunopathogenesis. Their blood levels provide criteria for diagnosing autoimmune lymphoproliferative syndrome and can provide a prognostic biomarker for cancer or effective therapeutic targets for these diseases.[2-7]

In order to make clinical decisions about autoimmune diseases, viral infections, solid tumors and hematopoietic diseases, transplant rejection, alterations of lymphocytic homeostasis and immunodeficiencies,[3-8] absolute and relative levels of lymphocytes are quantified through flow cytometry, so normal DNT-lymphocyte counts must be determined. This subpopulation can be identified without additional reagent costs because the values can be quantified through conventional analysis of $T, B$ and natural killer (NK) cells.

The purpose of this study was to determine the normal range of values of DNT lymphocytes in a population of healthy Cuban adults and the relation of these values with age and sex-such information could inform diagnosis and prognosis of multiple diseases.

\section{METHODS}

Design, subjects and sample selection A cross-sectional study was conducted in 2017-2018 at the Hermanos Ameijeiras Clinical-Surgical Teaching Hospital and The National Oncology \& 
Radiobiology Institute, Havana, Cuba. Subjects included 182 adult residents of Havana, aged 18-80 years (median age 40), 93 women and 89 men, all reportedly healthy, who were accompanying patients at hospital immunology services and who agreed to participate via written informed consent. Persons were excluded who smoked, consumed daily $>40 \mathrm{~g}$ of alcohol or its equivalent weekly; drank more than 4 cups of coffee daily; were pregnant; had recent or recurring infections in the previous 6 months or autoimmune or neoplastic diseases; or had taken antibiotics, immunostimulators, immunosuppressants or anti-inflammatory drugs in the past 6 months.

Flow cytometry Four $\mathrm{mL}$ of peripheral blood was extracted by antecubital venipuncture and deposited in cytometry tubes with the anticoagulant ethylenediaminetetraacetic acid (EDTA). Sample preparation adhered to the manufacturer's specifications for cell-surface immunophenotyping, using a protocol for no-wash red blood cell lysis with a Versalyse buffer (Beckman-Coulter, France).

An eight-color Beckman-Coulter Gallios flow cytometer (Beckman-Coulter, France) was used. The following fluorochrome-conjugated monoclonal antibodies were used: antiCD45-AA750/CD3-FITC/CD4-PC5.5/CD8-AA700/CD56-PE (all Beckman-Coulter, France). The DNT lymphocyte population was defined by the $\mathrm{CD}^{2} 5^{+} / \mathrm{CD}^{+} / \mathrm{CD} 4 / \mathrm{CD} 8 / \mathrm{CD} 56^{-}$immunophenotype. The data obtained were processed with Kaluza Analysis V1.5a software, with a minimum of 50,000 acquisition events. Absolute values were determined through a double platform and application of the following equation:

absolute value $($ cells $/ \mu \mathrm{L})=($ lymphocytes $/ \mu \mathrm{L}$ of hemogram $) x$ $(\%$ DNT) $\div 100$.

Statistical analysis Variables calculated include descriptive statistics, absolute and relative frequencies, mean, median and percentiles. To define value range, the normal distribution of variables was evaluated by the Shapiro-Wilk test. Most variables did not follow a Gaussian distribution. The effects of sex, age and their interaction were evaluated using a linear model. Reference values were expressed through the median and the 5th and 95th percentiles and stratified by sex and age group (18-25, 26-50, and 51-80 years).

Ethical considerations The project was approved by the research ethics committee of the Hermanos Ameijeiras Clinical-Surgical Teaching Hospital. Written informed consent was obtained from study participants after they received an explanation of the study's possible risks and benefits. The information was protected under principles of confidentiality without revealing participant identity. Diagnostic methods were selected based on the principle of maximum benefit, international and national standards, and accessibility of materials.

\section{RESULTS}

Percentages and absolute values of DNT lymphocytes are presented in Table 1. They were significantly lower in the 51-80 age group.
In both percentage and absolute values, the effect of age was highly significant, as evident in the variations observed between the oldest age group (51-80) and the two younger age groups (18-25 and 26-50).

\section{DISCUSSION}

At the time of this writing, there were no studies on referencevalue ranges for DNT lymphocytes in the Cuban population. Two publications reported that quantification of these cells is needed to diagnose autoimmune lymphoproliferative syndrome.[6,7] Although it is common for each laboratory to define specific ranges, there should be steady progress toward this goal. Given the dearth of data on reference values, and the urgency to collect such data, this study aims to propose ranges that amount to preliminary approximations for application at the national level.

Multiple factors are known to intervene in the variability of physiological ranges for these lymphocytes and for all immunesystem cells. The most studied factors are age and sex.[5] In this study, the effects of both age and sex were evaluated, and it was confirmed that the effect of age was significant, especially differences between those 51-80 years compared to those $\leq 50$. The low sex/age interaction confirms that these differences occur in both men and women and may be due to immunosenescence and thymic involution, the consequences of which become more evident near the sixth decade of life. In a study of healthy Cubans, a negative correlation was found between age and global T-cell count.[9]

The ranges obtained were wider and had higher medians than those reported internationally. These differences could be due to effects of lifestyle, diet and environmental conditions of the populations studied,[5,10] or because, unlike ours, the other studies did not exclude individuals with unhealthy habits or those consuming medications that could have affected immunological variables.[9] More local studies are needed to determine reference values of cells that can be used provisionally until studies with broader population representation can be conducted.

Table 1: Normal ranges (5th and 95th percentiles) for double-negative $T$ lymphocytes by sex and age group $(n=182)$

\begin{tabular}{|c|c|c|c|c|c|c|}
\hline \multirow{2}{*}{$\begin{array}{l}\text { Age groups } \\
\text { in years / Sex }\end{array}$} & \multicolumn{2}{|c|}{ Men $(n=89)$} & \multicolumn{2}{|c|}{ Women $(n=93)$} & \multicolumn{2}{|c|}{ Total } \\
\hline & Median & $\begin{array}{l}\text { Percentiles } \\
(5.0-95.0)\end{array}$ & Median & $\begin{array}{l}\text { Percentiles } \\
(5.0-95.0)\end{array}$ & Median & $\begin{array}{l}\text { Percentiles } \\
(5.0-95.0)\end{array}$ \\
\hline \multicolumn{7}{|c|}{ Range in percentage values (relative to total CD3 ${ }^{+}$CD56- lymphocytes) } \\
\hline $18-25(n=30)$ & 3.4 & $2.3-7.3$ & 5.2 & $2.1-7.8$ & 3.8 & $2.2-7.4$ \\
\hline $26-50(n=94)$ & 3.8 & $1.5-8.7$ & 4.0 & $1.8-7.7$ & 3.7 & 1.7-8.7 \\
\hline $51-80(n=58)$ & 2.6 & $1.2-7.3$ & 2.5 & $1.3-5.8$ & 2.6 & $1.3-6.6$ \\
\hline Total & 3.5 & 1.5-8.1 & 3.3 & $1.6-7.2$ & 3.4 & $1.6-7.4$ \\
\hline \multicolumn{7}{|c|}{ Range in absolute values (relative to total lymphocytes, cells/ $\mu \mathrm{L}$ ) } \\
\hline $18-25(n=30)$ & 71.5 & $32.1-166.7$ & 112.0 & $40.0-153.1$ & 90.0 & $32.6-163.7$ \\
\hline $26-50(n=94)$ & 61.5 & 29.9-188.7 & 67.0 & $26.7-138.3$ & 65.0 & $28.8-184.0$ \\
\hline $51-80(n=58)$ & 36.0 & $13.5-81.7$ & 40.0 & $18.6-92.0$ & 38.5 & $17.9-90.1$ \\
\hline Total & 59.0 & 23.0-185.0 & 57.0 & $22.7-132.2$ & 57.5 & $23.0-157.0$ \\
\hline Effects (DNT\%) ${ }^{a}$ & \multicolumn{6}{|c|}{$\begin{array}{l}F(\text { sex })=1.47(p=0.23) ; F(\text { age })=7.27(p<0.01) \\
F(\text { sex*age })=1.64(p=0.20)\end{array}$} \\
\hline Effects (DN\#) ${ }^{b}$ & \multicolumn{6}{|c|}{$\begin{array}{l}F(\text { sex })=0.32(p=0.57) ; F(\text { age })=28.74(p<0.001) \\
F(\text { sex*age })=0.19(p=0.67)\end{array}$} \\
\hline
\end{tabular}

a Percentage values (relative to total $C D 3^{+} \mathrm{CD} 56$ - lymphocytes)

${ }^{b}$ Absolute values (relative to total lymphocytes, cells $/ \mu \mathrm{L}$ )

F: Fisher's test for linear models 
Constraints in our study included the fact that the sampling was based entirely on residents of Havana with no one from other provinces; also, additional serological studies were not conducted, which reduced the possibility of diagnosing some chronic and infectious diseases that could have affected DNT lymphocyte values.

\section{CONCLUSIONS}

References were estimated for absolute values and proportions of double-negative $\mathrm{T}$ lymphocytes in healthy Cuban adults according to sex and age, and the importance of the effect of age was established. Absolute and relative concentrations of DNT lymphocytes were highest in younger age groups. - 1 -

\section{REFERENCIAS}

1. Melzer S, Zachariae S, Bocsi J, Engel C, Loffler M, Tárnok A. Reference intervals for leukocyte subsets in adults: results from a population-based study using 10-color flow cytometry. Cytometry B Clin Cytom. 2015 JulAug;88(4):270-81.

2. De Tullio G, Strippoli S, Angarano R, De Fazio $V$, Sgherza $N$, Negri $A$, et al. aß-Double negative CD4/CD8 (CD56) T cell (DNTs) in metastatic melanoma: basal frequency and behaviour during Ipilimumab treatment. Preliminary evaluations. J Transl Med [Internet]. 2015 [cited 2020 Jan 21];13(Suppl 1):O10. Available at: https://doi .org/10.1186/1479-5876-13-s1-o10

3. Haug T, Aigner M, Bruns H, Peuser M, Gebhardt $D$, Berger J, et al. Human double-negative regulatory $T$ cells modulate effector function of conventional $\mathrm{T}$ cells by selectively blocking mTOR signaling. Blood [Internet]. 2018 Nov 29 [cited 2020 Jan 21];132(Suppl 1):2410. Available at: https://doi.org/10.1182/blood-2018-99-112943

4. Voelkl S, Gary R, Mackensen A. Characterization of the immunoregulatory function of human TCR- $\alpha \beta$ CD4CD8 double-negative T cells. Eur J Immunol [Internet]. 2011 [cited 2020 Jan 21];41:739-48. Available at: https://doi .org/10.1002/eji.201040982

5. Apoil PA, Puissant-Lubrano B, Congy-Jolivet N, Peres M, Tkaczuk J, Roubinet F, et al. Reference values for T, B and NK human lymphocyte subpopulations in adults. Data in Brief [Internet].
2017 [cited 2020 Feb 15];12:400-4. Available at: https://doi.org/10.1016/j.dib.2017.04.019

6. Casado Hernández I, Marsán Suárez V, Díaz Domínguez G, Macías Abraham C. Utilidad diagnóstica de la evaluación de linfocitos T CD4+ CD8+ TCRaß+ en el Síndrome Linfoproloferativo Autoinmune. Rev Cubana Hematol Inmunol Hemoter. 2017;33(2):1-4. Spanish.

7. Casado Hernández I, Marsán Suárez V, Díaz Domínguez G, Macías Abraham C, Machín García S. Diagnóstico por citometría de flujo del Síndrome Linfoproliferativo Autoinmune. Rev Cubana Hematol Inmunol Hemoter 2017;36(Suppl):1-8. Spanish.

8. Wang Y, Lu W, LI A, Sun Z, Wang L. Elevated CD3 low double negative T lymphocyte is associated with pneumonia and its severity in pediatric patients. Peer J [Internet]. 2018 Dec 18 [cited 2020 Feb 15];6:e6114. Available at: https://doi .org/10.7717/peerj.6114

9. García Verdecia B, Saavedra Hernández D, Lorenzo-Luaces $\mathrm{P}$, de Jesús Badía Álvarez T, Leonard Rupalé I, Mazorra Herrera Z, et al. Immunosenescence and gender: a study in healthy Cubans. Immun Ageing [Internet]. 2013 Apr 30 [cited 2020 Feb 15];10(1):16. Available at: https://doi.org/10.1186/1742-4933-10-16

10. García-Dabrio C, Pujol-Moix N, Martínez-Pérez A, Ubeda J, Martínez C, Buil A, et al. Valores de referencia de las subpoblaciones linfocitarias en la población sana española. Hematológica. 2009;94(4):40. Spanish.

\section{THE AUTHORS}

Carlos Agustín Villegas-Valverde, physician with dual specialties in family medicine and immunology, and master's degrees in infectious diseases and medical education. Associate researcher, Immunology Laboratory of the National Institute of Oncology and Radiobiology, Havana, Cuba. https://orcid.org/0000-0001-7478-0482

Elena Kokuina, physician specializing in immunology, with a doctorate in medical sciences, clinical laboratory department, Hermanos Ameijeiras Clinical-Surgical Teaching Hospital, Havana, Cuba. Full professor, Medical University of Havana, Cuba. https://orcid.org/0000-0002 $-3651-7445$

Martha Camila Breff-Fonseca, physician and clinical laboratory specialist, Hermanos Ameijeiras Clinical-Surgical Teaching Hospital, Havana, Cuba.

Submitted: May 8, 2020

Approved for publication: September 16, 2020 Disclosures: None 


\title{
SARS-CoV-2 Transmission Channels: A Review of the Literature
}

\author{
Ekram W. Abd El-Wahab MBChB MPH PhD, Safaa M. Eassa MBChB MPH DrPH, Mohammed Metwally MBChB MS PhD, \\ Husam Al-Hraishawi DVM MS, Sherif R. Omar MBChB DTM\&H MPH DrPH
}

\begin{abstract}
BACKGROUND The novel coronavirus SARS-CoV-2 is responsible for the current global pandemic. There is a concerted effort within the global scientific community to identify (and thereby potentially mitigate) the possible modes of transmission through which the virus spreads throughout populations.
\end{abstract}

OBJECTIVE Summarize the ways in which SARS-CoV-2 is transmitted and provide scientific support for the prevention and control of COVID-19.

EVIDENCE AQUISITION We conducted an extensive literature search using electronic databases for scientific articles addressing SARSCoV-2 transmission published from December 28, 2019 through July 31,2020 . We retrieved 805 articles, but only 302 were included and discussed in this review. The report captured relevant studies investigating three main areas: 1) viral survival, 2) transmission period and transmissibility, and 3) routes of viral spread.

DEVELOPMENT Currently available evidence indicates that SARSCoV-2 seems to have variable stability in different environments and is

\section{INTRODUCTION}

The COVID-19 pandemic is caused by severe acute respiratory syndrome coronavirus 2 (SARS-CoV-2).[1] The outbreak, attributed to an emerging virus, was first identified in late November 2019, in Wuhan, China. WHO declared the outbreak to be a Public Health Emergency of International Concern (PHEIC) on January 30, 2020, and recognized it as a pandemic on March 11, 2020. As of August 2, 2020, a total of 17,628,109 confirmed cases of COVID-19 have been reported in 213 countries and territories, resulting in approximately 680,354 deaths. More than 11,349,471 people have since recovered.[2]

Given the urgency surrounding the pandemic, scientific publications and news outlets are consistently publishing emerging evidence on the ways in which SARS-CoV-2 is transmitted. However, these initial findings need to be carefully interpreted and monitored. The objective of this report is to review the available scientific literature on viral propagation, the risk of transmission and the importance of bundled prevention measures.

\section{EVIDENCE AQUISITION}

We conducted an extensive literature search covering the COVID-19 pandemic (from December 28, 2019 through July 31, 2020) in

\section{IMPORTANCE}

Many questions remain unanswered regarding SARS-CoV-2's modes of transmission. More research is needed to debunk speculations being made about SARS-CoV-2 and fill in the gaps in knowledge regarding the behavior of the virus and corresponding necessary preventive measures. This review is a contribution to the ongoing efforts to understand and adapt to the demands of the COVID-19 pandemic. very sensitive to oxidants, such as chlorine. Temperature and humidity are important factors influencing viral survival and transmission. SARSCoV-2 may be transmitted from person to person through several different routes. The basic mechanisms of SARS-CoV-2 transmission person-to-person contact through respiratory droplets, or via indirect contact. Aerosolized transmission is likely the dominant route for the spread of SARS-CoV-2, particularly in healthcare facilities. Although SARS-CoV-2 has been detected in non-respiratory specimens, including stool, blood and breast milk, their role in transmission remains uncertain. A complicating factor in disease control is viral transmission by asymptomatic individuals and through what would otherwise be understood as innocuous human activities.

CONCLUSIONS This article provides a review of the published research regarding human-to-human transmission of SARS-CoV-2 and insights into developing effective control strategies to stop viral propagation.

KEYWORDS COVID-19, SARS-CoV-2, transmission, pandemics, microbial viability

the major electronic databases (ISI Web of Knowledge, PubMed, Medline, ScienceDirect, EMBASE, EBSCO, ProQuest, and Google Scholar), the websites of WHO, CDC and the Mayo Clinic, and preprint platforms (bioRxiv, medRxiv, SSRN and Qeios), with the search terms: ["2019-novel coronavirus" OR "2019 nCoV" OR SARS-CoV-2 OR COVID-19 OR "novel coronavirus"] AND [transmit* OR spread OR shedding OR pandemic OR outbreak OR contact OR droplet OR aerosol OR "respiratory trans" OR "air borne" OR fecal OR oral OR "blood borne" OR "ocular trans" ${ }^{\star}$ " OR eye OR conjunctiv* OR "contact lens" OR "vertical transmission" OR "mother to child transmission" OR breastfeeding OR sexual OR zoonotic OR animal OR "vector borne" OR household OR "solid waste" OR "waste water" OR "organ transplant*" OR hemodialysis OR nosocomial OR "healthcare worker" OR "hospital infection" OR tobacco OR travel* OR refugee OR migrant OR homeless* OR "mass gathering" OR prison* OR incarcerat* OR detention OR addict*]. (Note that enclosing a term or phrase with quotation marks in a websearch filters out all responses that do not include exactly that term or phrase, and the inclusion of an asterisk after a group of letters in a websearch broadens the search by including all words that begin with those same letters). A total of 805 studies were retrieved and exported to the reference manager EndNote X8 (Thomson Reuters, London). A total of 258 duplicate studies were removed. We included research articles, review articles and clinical trials, case reports, correspondence, and situation reports that were published in English. All titles and abstracts were screened for relevance and full texts of potentially eligible articles were reviewed. The information was organized according to three main subjects: 1) viral survival, 2) transmission period and transmissibility and 3) routes of viral spread.

\section{DEVELOPMENT}

Viral survival

Viability and stability on surfaces The high transmissibility of SARS-CoV-2 could be attributable to the greater environmental 
viability of this virus compared to other human coronaviruses. Van Doremalen[3] analyzed the aerosol and surface stability of SARS-CoV-2 and compared it with SARS-CoV-1, the most closely related human coronavirus, on a variety of surfaces commonly found in household and hospital settings (aerosols, cardboard, plastic, copper and stainless steel), and estimated the decay rates using a Bayesian regression model. In the experiment, van Doremalen attempted to mimic viral deposits from an infected person onto everyday surfaces in a household or hospital setting, such as through coughing or touching objects. The researchers used a high-powered machine (threejet collision aerosolizer) to generate tiny artificial particles $(<5$ $\mu \mathrm{m})$.

Stability on surfaces was evaluated by depositing $50 \mu \mathrm{L}$ of virus and recovering the inoculum by swabbing, whereas viability of the virus in all surface and aerosol samples was quantified by end-point titration on Vero E6 cells. Throughout the duration of the experiment (3 hours), SARS-CoV-2 remained viable and was detectable, albeit with a drop in infectious titer from $10^{3.5}$ to $10^{2.7} \mathrm{TCID}_{50}$ per liter of air. The virus was more stable on plastic and stainless steel (2-3 days) than on copper (4 hours) and cardboard (24 hours). Similarly, Kampf found that SARS-CoV-2 can remain infectious for 2-9 days on different types of materials.[4] However, these experimentally-induced particles that remained suspended in aerosols do not seem to simulate those distributed from a sneeze or cough from a COVID-19 patient and thus does not reflect a clinical setting. [5-8] Importantly, authors sampled the air for just three hours, meaning the virus could potentially remain viable in the air for longer. Moreover, the authors did not verify whether these viruses were still capable of causing the disease. In this context, the two tested viruses behaved in a similar manner, but why SARS-CoV-2 has greater transmissibility remains unclear.

It is probable that SARS-CoV-2-infected individuals are spreading the virus before showing symptoms and likely that SARS-CoV-2, being novel, is highly contagious in an immunologically-naive population.[9] This brings into question whether the control measures that were effective against SARSCoV-1 are equally effective when deployed against SARSCoV-2. Until we learn more about virus viability in a variety of settings and conditions, we have to consider all potential routes of transmission.

These studies provide key information about the stability of SARS-CoV-2. The findings may have important repercussions for medical workers as well as the public and suggest that people may acquire the virus through the air or after touching contaminated objects. SARS-CoV-2 is quite transmissible through relatively casual contact, making this pathogen very hard to contain. The virus can live on items we touch often every day-such as mobile phones, tablets, computer keyboards, door handles and elevator buttons - for just as long and thus these objects should be disinfected frequently. However, on copper surfaces, which contain natural antimicrobial and virucidal properties and have been shown together with silver and aluminum to inactivate microbes,[10] SARS-CoV-2 was able to survive for four hours.
Physical and chemical inactivation Pastorino evaluated the heating and chemical protocols for inactivating SARS-CoV-2 while processing respiratory samples exhibiting higher viral loads than droplets. A temperature of $60{ }^{\circ} \mathrm{C}$ for 60 minutes was sufficient to inactivate SARS-CoV-2 in low viral loads, while heating samples to $92{ }^{\circ} \mathrm{C}$ for 15 minutes was more effective in achieving a reduction of $6^{*} \log$ (viral load) highly loaded clinical samples.[11]

Alex Chin at the University of Hong Kong found that SARS-CoV-2 is persistently stable at a temperature of $4{ }^{\circ} \mathrm{C}$. The study showed the virus can stay viable at high levels at room temperature for 7 days (eliminated after 14 days), and will gradually abate at $27{ }^{\circ} \mathrm{C}$ over 24 hours or after 30 minutes at $56{ }^{\circ} \mathrm{C}$ or after 5 minutes incubation at $70^{\circ} \mathrm{C}$.[12]

Thus far, there is no direct evidence on the influence of ambient temperature and humidity on SARS-CoV-2 transmission, and the activity or behavior of the virus in different climatic conditions is still unknown.[13] During the winter season in the Northern Hemisphere, that is before March 22, 2020, 90\% of COVID-19 cases had been recorded in non-tropical countries with low temperatures and low humidity.[14]

Wang investigated the role of temperature and humidity in reducing SARS-CoV-2 viability. After fitting a regression model, they found that both high temperature and high relative humidity had a significant effect on the reproductive number $\mathrm{R}$. One degree Celsius increase in temperature and one percent increase in relative humidity lowered $\mathrm{R}$ by 0.0225 and 0.01158 , respectively. Although their results indicated that SARS-CoV-2 transmission may be reduced with the arrival of summer and rainy seasons in the northern hemisphere, it is still unclear whether these findings will hold true in extremely hot, extremely cold or extremely dry areas, since the threeday (January 21-23, 2020) average temperatures and relative humidity ranged from $-21{ }^{\circ} \mathrm{C}$ to $21{ }^{\circ} \mathrm{C}$ and from $47 \%$ to $100 \%$ humidity.[15]

Sajadi also found that temperatures $>32^{\circ} \mathrm{C}$ and high humidity influenced the spread of SARS-CoV-2, illustrating in their study that the virus has established significant community spread in cities and regions lying along a narrow east-west distribution, with consistently similar weather patterns $\left(5^{\circ} \mathrm{C}-11\right.$ ${ }^{\circ} \mathrm{C}$ and $47 \%-79 \%$ humidity).[16] This suggests that weather factors may affect the virus, particularly humidity and hours and intensity of sunshine. On the other hand, Marc Lipsitch of Harvard's T.H. Chan School of Public Health recently posted an analysis in which he concluded that warmer weather will "probably not" significantly slow the spread of the novel virus. [17]

A log-linear generalized additive model controlling for potential confounders was used to analyze the effects of temperature and relative humidity on daily new cases and daily new deaths of COVID-19 in 166 countries (excluding China) as of March 27,2020 , where higher temperatures and relative humidity were both negatively related to daily new cases and deaths. [18] Consistently, lower humidity was associated with a 6-fold increase in locally-acquired positive COVID-19 cases in Sydney during the early stages of the epidemic. 
Mecenas observed great homogeneity in a systematic review on effects of temperature and humidity on SARS-CoV-2's seasonal viability and transmissibility. Cold and dry conditions were potentiating factors for viral transmission, whereas warm and wet climates seem to reduce spread. They concluded that the lower the humidity and the drier the air, the smaller the aerosols that can stay suspended in the air for longer durations. On the other hand, when the air is humid, the aerosols become larger and heavier, thus settling on surfaces more quickly, leading to a decreased chance of infection through airborne transmission.[19]

Inactivation by biocidal agents has been studied extensively. For instance, experimental studies demonstrated that the virus can be efficiently inactivated by several surface disinfectants. Ethanol (62\%-71\%) reduced coronavirus infectivity by 2.0 $4.0 \log _{10}$ with an exposure time of one minute. Hydrogen peroxide $(0.5 \%)$ and sodium hypochlorite $(0.1 \%-0.5 \%)$ each cause $>3.0 \log _{10}$ reduction in viral titers within one minute. The virus can also be inactivated by 2-propanol (70\%-100\%), the combination of 2-propanol (45\%) with 1-propanol (30\%), formaldehyde $(0.7 \%-1 \%)$, glutardialdehyde $(0.5 \%-2.5 \%)$, and povidone-iodine $(0.23 \%-7.5 \%)$, all reducing its infectivity by $4 \log _{10}$ or more.[9] In another setting, sodium-dodecyl-sulfate and Triton-X100, when added to guanidinium thiocyanate-lysis buffers, resulted in a $6_{\log }$ reduction of virus in highly infectious clinical samples.[11]

The SARS-CoV-2 virus has been specifically tested for its ultraviolet (UV) susceptibility. Like many related coronaviruses, including the SARS coronavirus, SARS-CoV-2 was found to be highly susceptible to UV inactivation. For instance, UV-Cbased disinfection was found helpful in stopping the SARSCoV-2 virus from replicating.[20,21] A class of transparent conductors allowing for high levels of UV light to sufficiently kill the virus has been recently released for use in disinfecting public areas.[22]

Transmission period and transmissibility People infected with SARS CoV-2 can be contagious prior to the onset of symptoms, as many laboratory-confirmed cases were asymptomatic.[23-25] Asymptomatic carriers emerge as a new challenge for disease control. Moreover, post-discharge surveillance revealed that the duration of viral shedding may extend for more than one month after recovery and seroconversion.[26-28]

Early transmission dynamics showed the basic reproduction number, $\mathrm{R}_{0}$ of SARS-CoV-2 was 2.2 to 2.7,[29-31] although in other models it was calculated as 3.3[32] and 5.7.[33] The real-time reproduction number $\left(R_{t}\right)$ was consistent with $R_{0}$, albeit with variations in different countries: Italy (3.1); Spain (3.95); Germany (4.43) and France (6.56).[34] This implies that different mathematical approaches and assumptions may yield different results, and transmission dynamics may vary geographically.

\section{Routes of viral spread}

Respiratory droplets and aerosols SARS-CoV-2 is classified according to the US Centers for Disease Control and Prevention (CDC) as a respiratory virus, and is thus believed to be transmitted mainly through "respiratory droplets" when infected people sneeze, cough or talk. Like many respiratory viruses, including flu, SARS-CoV-2 can be spread in tiny droplets released from the nose and mouth of an infected person as they cough.[35] A single cough can produce up to 3000 droplets, and droplet diameters vary greatly (1-2000 $\mu \mathrm{m})$. [36] If enough pathogens are present in the droplets, they may be inhaled and spread to others. When airborne, the droplets' moisture quickly evaporates, leaving droplet nuclei. The size of the nuclei and whether they carry pathogens determine their infectivity. Humans can inhale particles containing pathogens with diameters of 2-10 $\mu \mathrm{m}$, which account for some 60\%$80 \%$ of droplet nuclei produced by coughing and sneezing, respectively.

The inhaled particles can then settle in the alveoli and cause infection. Droplet nuclei produced by coughing are equivalent to only about $5 \%$ of sneezing droplets (sneezing droplets spreading more effectively.) Unless a large number of pathogens are present in droplet nuclei produced from saliva, sneezing or coughing, it is unlikely that these actions are directly responsible for transmission.[37] The longest sneezing transmission distance was found to be $1.7 \mathrm{~m}$, and most of the droplets with particles of $0.36 \mu \mathrm{m}$ fell to the ground.[38] Larger particles carrying pathogens will thus settle and contaminate other objects, such as door handles, seats, public transport handrails, elevator surfaces, etc., which then pose the risk of indirect contact transmission.[37]

Assuming that inhaled particles $<50 \mu \mathrm{m}$ can settle in the nasal cavity, these particles would then account for $>95 \%$ of the droplet nuclei produced from sneezing and coughing. However, one study found that $99.99 \%$ of pathogens are carried by particles larger than $50 \mu \mathrm{m}$.[39] Apparently, viral transmission through droplets requires the infected person to eject a large number of pathogens to result in direct transmission. When there is no air flow interference, it takes about 30-60 minutes for $90 \%$ of the droplet nuclei carrying pathogens to disappear from the air. Droplet nuclei with a diameter $>4-8 \mu \mathrm{m}$ usually disappear within 90-120 minutes. With airflow, the droplet core disappears from the air faster.

These data were recently updated using spray droplet measurement systems and spray scan laser sheets to analyze droplet production from coughs and speech by measuring the droplet size distribution, trajectory, travel distance and velocity, and time spent airborne in relation to the level of ventilation.[40,41] In a study conducted by Lewis,[42] although large $(100-1000 \mu \mathrm{m})$ and small $(1-10 \mu \mathrm{m})$ droplets were produced during coughing, only small droplets appeared during speech. Droplets produced by sneezing coming from both the oral and nasal cavities were predominately large ones. These did not travel far before gravity bent their trajectory downward, falling on the ground within one second. On the other hand, droplets as small as $5 \mu \mathrm{m}$ took almost 9 minutes to reach the ground when produced at a height of $160 \mathrm{~cm}$. This finding has key implications for aerosol transmission of SARS-CoV-2.[42] Importantly, normal breathing did not produce any kind of droplets. Ventilation of spaces substantially diluted respiratory droplets, thus poorly ventilated and populated spaces could contribute to the spread of SARS-CoV-2. 
Available research suggests that bioaerosols generated directly through exhalations may spur SARS-CoV-2 transmission. This could help to explain why SARS-CoV-2 is so contagious and how asymptomatic and mildly infected people may fuel the spread of the virus. Airborne transmission is plausible since virus particles that were experimentally aerosolized could remain viable for up to 3 hours.[3] William Ristenpart, a professor of chemical engineering at University of California-Davis, stated that SARS-CoV-2 spreads primarily via aerosols emitted when people speak.[43]

People emit virus particles in a range of sizes including small droplets or fine particles, or "aerosols", that can be suspended in the air for hours and flow with air currents long enough to infect passersby.[44] Bourouiba, in a new model of respiratory emissions, stated that under the right conditions, peak exhalation speeds can reach up to $10-30 \mathrm{~m} / \mathrm{s}$. Liquid droplets from sneezes, coughs and even breathing are trapped in turbulent gas clouds, allowing them to travel $>7-8 \mathrm{~m}$, and linger in the air for minutes. Pathogens in the cloud could potentially reach air circulation systems inside buildings. The best defenses are the outdoors and open windows where air circulation or wind disperse and dissipate the clouds reducing droplet concentrations.[45] However, the author did not look at gas clouds of patients infected with the SARS-CoV-2 virus.

A recent study found live SARS-CoV-2 particles to be widely distributed in the air and on object surfaces in the intensive care unit (35\% of samples) and general ward $(12.5 \%$ of samples) of the Huoshenshan Hospital in Wuhan, China. SARS-CoV-2 aerosols were most concentrated near and downwind to patients' rooms. These results confirm that SARS-CoV-2 aerosol exposure poses risks, and that the maximum transmission distance of SARS-CoV-2 aerosol might be 4 meters.[46] In a hospital in Nebraska, USA, viral RNA was found in two-thirds of air samples collected in isolation rooms for severely ill COVID-19 patients and in a quarantine facility housing those with mild infections. Viral RNA was also isolated from surfaces on ventilation grates.[47] In another study, viral RNA from SARS-CoV-2 was found in a number of locations, including department stores.[48] Although the three aforementioned reports did not confirm whether the collected aerosols are capable of infecting new cells, the data suggest that viral aerosol particles are produced by infected individuals, even in the absence of cough or sneezing.

On the other hand, there are reports from settings where no SARS-CoV-2 RNA was detected in air samples collected $10 \mathrm{~cm}$ in front of symptomatic COVID-19 patients who were breathing, speaking and coughing.[49-51] It is important to note that RNA detection in environmental samples based on PCR assays is not necessarily indicative of viable, transmissible virus.

Airborne transmission of SARS-CoV-2 may be possible in certain circumstances in which aerosol-generating procedures (AGPS) are performed, such as respiratory tract suction before or after intubation, nebulizer treatment, manual ventilation, oxygen mask manipulation, bronchoscopy, chest compression or cardiopulmonary resuscitation, tracheostomy, or disconnecting a patient from a ventilator.[52] Further studies are needed to determine whether it is possible to detect the COVID-19 virus in air samples from wards where no therapeutic procedures that generate aerosols are ongoing.

Active SARS-CoV-2 has been detected in patients' saliva by cell culture, although serial monitoring over time showed declining viral load.[53] Saliva can be discharged through coughing and can contain nasopharyngeal or lung secretions. When there is no coughing or in patients with no symptoms, SARS-CoV-2 can still be transmitted directly or indirectly through saliva.[35,53,54]

On March 29, 2020, WHO stated that aerosol transmission of the virus needs further evaluation and confirmation, and the number and distribution of SARS-CoV-2 in droplet nuclei ejected by coughing or sneezing have yet to be confirmed by research.[52] It is crucial to know the concentration of SARSCoV-2 particles which would result in a significant likelihood of infection. The duration of exposure necessary to inhale enough virus to cause infection is likely also an important factor. Under favorable combined conditions of airflow, humidity and temperature, an infectious dose of the virus might build over time. We should acknowledge the difficulty of obtaining data in this context since deliberately exposing people and measuring the infection rate at different doses would be unethical.

Evidence-based hypotheses support the possibility of SARSCoV-2 airborne transmission due to its persistence in aerosol droplets in a viable and infectious forms. Based on available knowledge and epidemiological observations, it is plausible that small particles containing the virus may diffuse in indoor environments covering distances up to 10 meters from emission sources.[55,56] This explains the anomalous COVID-19 outbreaks in northern Italy, ranked as one of the most polluted areas in Europe and characterized by high particulate matter concentrations.[57]

On July 6, 2020, more than 200 scientists submitted an open letter to WHO warning about airborne transmission of SARSCoV-2 via aerosols and urging the organization to recognize the risks. On July 9 , WHO responded with an update in which it acknowledged with hesitation the growing evidence of airborne spread of the disease.[58]

Contact transmission Contact transmission of SARS-CoV-2 can occur through indirect contact with fomites in the immediate environment around the infected person or with commonly touched surfaces of objects potentially contaminated by landed patient secretions (nasal cavity, oral cavity, conjunctiva, etc.), such as door knobs, seats, elevator surfaces, faucets, public transport handrails, computer mice, trash bins, etc. Susceptible individuals can then be infected through the nasal mucosa or conjunctiva when touching the nostrils or rubbing the eyes. $[59,60]$ It is reported that SARS-CoV-2 RNA has been detected on hospital door handles in Shandong and Guangzhou, China. [39] In a study at the University of Nebraska Medical Center, besides medical equipment, about $80 \%$ of frequently touched miscellaneous personal items tested positive for SARS-CoV-2 RNA by reverse transcription polymerase chain reaction (RT-PCR). These included exercise equipment, personal computers, tablets, cellular phones, reading glasses, remote controls for in-room TVs, toilet seats, room surfaces, tables, bed rails and window ledges.[47] A case report published 
by the CDC suggested SARS-CoV-2 transmission may have occurred via contact with contaminated surfaces. In that case, a SARS-CoV-2-infected asymptomatic person attended a church service and transmitted the disease to another person who sat in the same seat later that day. Nevertheless, it could not be ascertained whether the virus was contracted via a contaminated surface or through lingering aerosol.[25]

Since SARS-CoV-2 could remain viable for several days on surfaces such as cardboard, plastic and steel,[3] concerns have been raised about packages, shipments and groceries. [61] Although these items are likely safe, it is possible that an infected person could unknowingly deposit a significant amount of contaminant on them. Thus, it is advisable to wipe down these items using approved disinfectants.[61] Nonperishable items with same-day delivery can be left to sit for 12-24 hours at room temperature to minimize risk. Given current epidemiological data, it is possible that contact with SARS-CoV-2-contaminated surfaces may be one of its main transmission routes, although controversy remains about how much and for how long SARS-CoV-2 can survive on different contaminated surfaces.

Fecal-oral transmission Early in the outbreak, fecal-oral transmission was flagged as a possible route for SARSCoV-2 spread.[62] The angiotensin-converting enzyme 2 (ACE2) receptors used by SARS-CoV-2 to enter cells are highly expressed in lung alveolar type 2 cells and in upper esophageal and stratified epithelial and absorptive enterocytes in the ileum and the colon.[63-66] SARS-CoV-2 was detected in the intestinal tissues of animals exposed to the virus. The virus was also detected in biopsy specimens and stool, even in patients discharged after recovery, which may at least partially explain reported gastrointestinal symptoms,[67,68] potential recurrence, and transmission of SARS-CoV-2 from persistently shedding patients.[69,70]

Recent evidence has confirmed the presence of SARS-CoV-2 in fecal specimens from COVID-19 patients, and live virus has been cultured from stool samples.[71-74] Digested sputum may represent the origin of the virus in stool.[75] However, viral RNA concentration in anal swabs was higher than in the blood,[76] suggesting that the virus might replicate in the digestive tract. Contamination of hands, food and water may occur via contact with fecal content and may cause infection by invading the oral cavity and respiratory tract.[69,77-80] Chen recorded viral shedding at multiple time points in stool specimens. [81] Although all specimens were not equally consistent with oropharyngeal swabs, stool samples tested positive for SARSCoV-2 RNA in 28 (66.7\%) patients, of whom 18 (64.3\%) remained positive for fecal viral RNA after the virus had cleared from their nasopharynxes. The average duration of viral shedding from feces after negative conversion in pharyngeal swabs was 7 days, although in some cases, this extended up to 4-5 weeks.[70] Interestingly, detection of SARS-CoV-2 RNA in stool was not linked to concurrent gastrointestinal symptoms, illness severity or particular demographic, clinical, laboratory or radiologic findings.[81]

Similarly, Wu verified the presence of SARS-CoV-2 RNA in 55\% of fecal specimens of patients with a positive oropharyngeal swab (RT-PCR).[82] Considering the infectiousness of SARS-CoV-2 isolated from stool samples, three studies have successfully cultured SARS-CoV-2 with a typical morphology from stool specimens in Vero cells.

The aforementioned evidence affirms the potential for fecal-oral or fecal-respiratory transmission of SARS-CoV-2, [71,83,84] even after patients have tested negative with RT-PCR oropharyngeal swab. Accordingly, treated patients who meet discharge criteria with a negative oropharyngeal swab should be advised they may still spread the disease via the fecal shedding route. Setting a negative fecal viral RNA test as part of the criteria for patient discharge is thus warranted.

Ocular transmission (Conjunctiva, tears, contact lenses) Tears are one of the body fluids that can transmit SARS coronavirus. [85] Although ACE2 proteins are widely distributed in many organs of the body (skin, lymph nodes, thymus, bone marrow, spleen, liver and brain),[63] their expression in conjunctival epithelia is yet to be confirmed. Lu stated that the route of conjunctival COVID-19 infection and tear transmission cannot be ignored, as unprotected ocular exposure (while fullygowned with a protective suit and N95 respirator) was thought to be responsible for nosocomial infections in the Wuhan Fever Clinic.[86,87] Ocular fluid from SARS-CoV-2-infected patients was found to contain the virus. This occurred early in the disease course and was confirmed by viral RNA detection.[88] Similar case presentation and findings were reported by other scholars.[89-91] These findings highlight the importance of hygienic measures and appropriate use of personal protective equipment (PPE), because ocular mucosa could be both a site of virus entry and a source of contagion.

Liang and Wu detected SARS-CoV-2 RNA by RT-PCR in the conjunctival sac of 37 COVID-19 patients, of whom 3 had conjunctival congestion/inflammation. The viral load of conjunctival sac secretion was relatively low and proportional to the severity of the disease,[92] suggesting that ocular symptoms commonly appear in patients with severe pneumonia.[93] Reports of typical signs and symptoms from 55,924 laboratory-confirmed cases showed that conjunctival presentation was found in $0.8 \%$, and it was unclear whether it was an initial or a concurrent symptom.[70,94,95] Indeed, SARS-CoV-2 may cause tears and conjunctivitis in the case of direct inoculation, migration of an upper respiratory tract infection, or hematogenous involvement of the lacrimal gland. [96]

In a prospective interventional case series study, Xia collected tears and conjunctival secretions at an interval of two-three days and tested for SARS-CoV-2 by RT-PCR. They found that tears and conjunctival secretions were positive for viral RNA only if COVID-19 pneumonia patients had conjunctivitis. However, isolation of the virus was unsuccessful. These results suggest that SARS-CoV-2 does not replicate in conjunctival epithelia and that ocular transmission is unlikely.[97] On the other hand, when tear sampling time points covered two weeks of active infection in an attempt to provide a good representation of the full disease course, all tear samples including those from patients with ocular manifestations, showed negative results, although nasopharyngeal swab samples continued to test 
positive. Importantly, tear samples were incubated in cell lines four days before RNA extraction to rule out the possibility of false negative RT-PCR if a cytopathic effect could be observed. This again suggests that the risk of transmission through tears regardless of the phase of infection is likely low.[98]

Contact lenses have been raised as a potential concern for increased risk of exposure to the virus, although no evidence of contracting COVID-19 infection through handling contact lenses has been reported thus far. However, as contacts can cause eye irritation, wearers touch their faces when putting on and removing contacts, and may rub their eyes more often, all of which puts them at a higher risk for acquiring infection. Contact lens wearers may wish to opt to use spectacles, instead.[99]

Mother-to-child transmission Given the changes to physiology and immune function during pregnancy, pregnant women might face greater risks of being infected by SARS-CoV-2. Many diseases can be transmitted vertically by the mother-to-child route. Although mother-to-child transmission of SARS-CoV-2 still requires more evidence before it can be confirmed, there have been cases that point to the possibility of this route. Evidence for such transmission was based on clinical and laboratory findings, particularly elevated IgM (immunoglobulin M) antibody values in blood drawn from neonates following birth,[100-102] or positive neonatal nasopharyngeal swabs for SARS-CoV-2 RNA by RT-PCR.[103] Positive IgM results with their inherent challenges of false positivity or cross reactivity with other congenital infections (sensitivity and specificity of $70.2 \%$ and $96.2 \%$, respectively) are not definitive evidence of in utero infection. In many cases, infection in early infancy may have occurred due to postnatal contact with COVID-19positive parents or caregivers.[104]

A meta-analysis of 21 articles, which included 92 neonates born to 90 mothers infected with COVID-19, found no differences in the clinical characteristics of pregnant women and non-pregnant COVID-19 patients. Maternal COVID-19 infection has caused higher incidence of fetal distress and premature labor, although vertical transmission was rare (4 out of 86 neonates tested positive for the virus by RT-PCR). [105] An additional report of 10 pregnant women infected with COVID-19 resulted in similar findings: that is, while no vertical transmission of SARS-CoV-2 occurred after delivery, perinatal infection had produced adverse effects on newborns including intrauterine fetal distress, premature labor, respiratory distress, thrombocytopenia and abnormal liver function, and even death. [106]

The cause of such neonatal illness or death remains unclear, and the possibility of false negative PCR tests cannot be ruled out. More specimens, including umbilical cord blood, amniotic fluid, gastric fluid, stools or anal swabs from the neonates should have been collected to optimize detection of viral RNA. Furthermore, the placenta tissue should have been examined for possible placental inflammation caused by viral infection. In any case, when these samples were considered in further studies, all tested negative for SARS-CoV-2.[107-110] This suggests that placental shedding and mother-to-child transmission is unlikely for this virus, probably due to low maternal viremia. [84] The criteria that should be used for definitive diagnosis of vertical SARS-CoV-2 transmission remain unclear. One suggestion is a neonatal nasopharyngeal swab positive for virus within one to two hours of birth and before contact with an infected individual, and an elevated IgM level for the virus in cord blood. Although clinical characteristics of COVID-19 in pregnant women were similar to infected non-pregnant women, the case fatality of COVID-19 among pregnant women was $25 \%$. The related complications included acute respiratory distress syndrome, disseminated intravascular coagulopathy, secondary bacterial pneumonia, renal impairment and sepsis. $[105,111,112]$

It is noteworthy that in all previous reports, pregnant women were recruited in their third trimester, and thus the possibility of intrauterine vertical transmission during the first or second trimester cannot be ascertained.[113] The impact of rubella infection, for example, increases two-fold in the first trimester compared to the second trimester.[114] Moreover, all infected pregnant women underwent caesarian delivery, thus whether normal labor or uterine contractions increase the risk of motherto-child transmission has yet to be clarified.[112,113,115] In a retrospective study, vaginal delivery was described as carrying a low risk of intrapartum SARS-CoV-2 transmission to the newborn, although one newborn tested positive after a vaginal delivery.[116] Several cases of uncomplicated labor and vaginal delivery in women with COVID-19 were reported.[117,118]

Breastfeeding Breast milk provides protection against many illnesses. Currently, it is unclear whether SARS-CoV-2 can spread via breast milk, but an infected mother can transmit the virus to her infant via respiratory droplets during breastfeeding. [111] In limited studies, SARS-CoV-2 has not been found in breast milk, [108] but fragments of the viral RNA were detected by RT-PCR in a few breast milk samples of infected mothers although the isolated virus was not viable.[119] This does not rule out the possibility that mothers with COVID-19 could spread the virus via breast milk.

Confirmed or symptomatic mothers under investigation should take all possible precautions to avoid spreading the virus to their infants. When two mothers with COVID-19 who contracted the infection in the post-partum period breastfed without a mask, their newborns tested positive for SARS-Cov-2.[116] As per WHO recommendations, mothers with suspected or confirmed COVID-19 are encouraged to initiate or continue breastfeeding. [120] Whether mothers decide to express milk or to breastfeed directly, strict hygiene measures should be followed including face masks, hand washing and use of a breast pump.[121]

Sexual transmission Without a doubt, SARS-CoV-2 has implications for sexual and reproductive health.[122] Whether SARS-CoV-2 is sexually transmitted is largely irrelevant to the risks of having sex with someone who is infected. Early in the pandemic, SARS-CoV-2 was thought unlikely to be spread through sexual intercourse, according to a study that found no molecular evidence of SARS-CoV-2 in collected semen samples[123] and testicular biopsy specimens[124] from 34 Chinese men with mild to moderate COVID-19, one month after diagnosis. Moreover, Cui did not detect any SARSCoV-2 RNA in vaginal swabs of 35 COVID-19-positive female patients and found no evidence of sexual transmission to their 
male partners.[125] More recently, 6 of 38 semen samples of COVID-19-infected men tested positive for SARS-CoV-2. Two of these samples were from patients who recovered. [126] However, since then, the virus has been found in feces, saliva and mucous, $[39,53,54]$ and the virus may be transmitted through anal or oral sex.[127] On the other hand, Wang provided bioinformatics evidence that human testes may be highly vulnerable to SARS-CoV-2 infection since ACE2 and transmembrane serine protease 2 (TMPRSS2), both of which act as receptors for SARS-CoV-2, are found in high numbers in human testicular tissue.[128] These findings provide potential clues for further investigations. Collectively, SARS-CoV-2 can be seeded in the male reproductive tract, and sexual transmission might contribute a critical proportion of overall viral propagation.

Zoonotic transmission COVID-19 is a zoonotic disease, whose spread was accelerated by modern human transportation and crowded urban environments, as well as through nosocomial transmission once severely-ill patients were hospitalized. [129-131] Little is known about the presumed animal reservoir. Preliminary reports based on the codon usage and originunknown homologous recombination of the spike glycoprotein suggested snakes as the possible wildlife source of the novel coronavirus.[132] However, RNA analysis revealed the virus to be most closely related to a coronavirus isolated from horseshoe bats (CoV RaTG13) living in Yunnan Province caves.[133-143]

Horseshoe bats are maintenance hosts for SARS-related coronaviruses, and SARS-CoV-2 may have emerged in a similar way through sequential genetic recombination events prior to spillover into an intermediate host, thus qualifying as zoonotic transmission.[129,144,145] Epidemiological evidence indicated that several episodes of zoonotic transmission occurred in late November 2019 at a Wuhan city wholesale market, where live wild animals including snakes, bats, marmots, deer and some game animals were illegally traded. $[129,146]$ Frequent human-animal interactions and low levels of environmental biosecurity in rural communities in southern China were identified as risks for zoonotic disease emergence. [147] Future in-depth research on specific risk factors will help tailor more fine-tuned risk mitigation strategies to reduce threats of emerging zoonoses.

There have been a few reports of infected pet dogs,[148,150] cats[151,152] and other domesticated animals.[148,152,153] However, there is currently no evidence of SARS-CoV-2 spreading from humans to pets or vice versa. Indeed, SARSCoV-2-positive dogs on RT-PCR had negative culture and serological tests, suggesting that the virus was unable to reproduce even when the best possible medium was provided. In one study, the COVID-19-positive dog never seroconverted to create antibodies against the virus, suggesting a weak infection not capable of eliciting an immune response and that the dog was never contagious to other pets or people. This means that the risk of pets serving as a source for SARS-CoV-2 infection, or for pets catching the disease from humans, must be extremely low. Research is being planned to better understand the risks and consequences of SARS-
CoV-2 infections in domestic animals. As part of the planned research, pet owners will be surveyed for particular interactions or behaviors that may contribute to the spread of the virus from humans to animals. Until we learn more, COVID-19-positive pet owners should exercise caution and appropriate physical distancing to keep their pets safe. Contact with pets in regard to kissing, petting or snuggling, sharing food, bedding, towels or dishware should be restricted.[154,155]

Air conditioning cooling systems New research suggests that air conditioning (AC) may circulate infectious droplets containing SARS-CoV-2. In fact, air conditioning has always had the ability to influence virus circulation, but concerns for SARS-CoV-2 are extreme given the great susceptibility of the population-atlarge to the virus and the current lack of a vaccine. An outbreak of COVID-19 in an air-conditioned restaurant in Guangzhou, China, involved nine persons in three family clusters. The infection was transmitted by a symptomatic index case at a table that was located in front of an AC unit to people at the same table as well as to others at a neighboring table. Although the six smear samples from the air conditioner intake and outtake hose all tested negative for SARS-CoV-2 as confirmed by RT-PCR, virus transmission in this outbreak cannot be explained by droplets alone. The scenario was consistent with droplet transmission prompted by the direction of the AC airflow, since lower concentrations of adrift aerosols at greater distances were insufficient to cause infection in other parts of the restaurant.[156]

AC systems may pose the same danger in home settings particularly in the case of central cooling units. Opening windows rather than using $A C$ would allow better air exchange and minimize viral spread.[157] In restaurants and banquet halls, it is crucial to increase the distance between tables and improve temperature-monitoring and ventilation surveillance. Ceiling fans with upward airflow rotation combined with upperair ultraviolet germicidal irradiation (UVGI) disinfection systems can be utilized.[158]

Household clusters Family clustering has been an important factor in SARS-CoV-2 transmission.[75] The secondary transmission rate among cohabiting family members and close contacts is highly variable $(5 \%-100 \%),[26,30,31,159]$ and transmission is mainly through respiratory droplets or through close contact. Cohabiting children (<20 years) are 4 times less likely than older adults ( $\geq 60$ years old) to catch SARS-CoV-2 with no risk differences by sex.[160] Variations in the clinical manifestations of the disease can occur across secondary cases. Asymptomatic carriers may remain asymptomatic, develop mild symptoms or even develop severe COVID-19.[24,160-167] Given that the viral loads of symptomatic and asymptomatic patients are similar,[168] silent patients (asymptomatic or minimally symptomatic) have high transmission potential and can still infect others. Moreover, transmission may occur early in the course of infection during the incubation period, $[24,160,166,167,169]$ which substantially impedes any potential of curbing the ongoing pandemic. This highlights the importance of epidemiological investigation of family-associated incidence rates, close contact tracing and longitudinal surveillance. Silent patients should be subjected 
to isolation and continuous reassessment by virus-specific nucleic acid tests.[161,162,166,169]

Infected children have been identified largely through contact tracing in households of adults.[170] A recent study of 65,000 youngsters found that those between the ages of 10 and 19 years are capable of spreading SARS-CoV-2 within households just as effectively as adults.[171] SARS-CoV-2 transmission can be particularly efficient in crowded, confined indoor spaces such as homes and workplaces where transmission rates can reach as high as 43\%.[172-175]

Foodborne transmission Currently foodborne exposure to SARS-CoV-2 is not believed to be a route of transmission. $[75,176]$ Because most initial cases had visited a wet market in Wuhan selling various exotic live animals, misinformation had circulated about the possibility of contracting SARS-CoV-2 if someone had eaten bats or bat soup. The mode of transmission became clearer after an explicit outbreak investigation that pointed to exceptionally wide contamination of a seafood market by bat excreta.[177]

Several factors could make transmission of SARSCoV-2 through food less likely, even if the virus is present on food: i) cooking at least $60{ }^{\circ} \mathrm{C}$ usually kills viruses in meat and animal tissue, while it is certainly possible that transmission could occur if someone prepared a bat for a meal or consumed it undercooked; ii) unlike bacteria, viruses cannot grow inside food; iii) because of the poor stability of SARS-CoV-2, it cannot survive for long on surfaces and would be expected to dwindle with time if it accidently contaminated foodstuffs; iv) unlike other enteric viruses (norovirus, rotavirus, astrovirus or hepatitis A virus), SARS-CoV-2 has a different structure and cannot survive in the acidic stomach media;[178] v) moreover, food safety measures that are already in place to prevent foodborne illness reduce the transmission of any virus particles through food.[178,179]

Waterborne transmission SARS-CoV-2 has not been detected in drinking water but was found in untreated wastewater. [180] As we pointed out earlier, SARS-CoV-2 nucleic acid has been found in urine and fecal matter of COVID-19 patients $[67,73,74,77,181]$ and the virus was successfully cultured from some specimens.[71,72] While data are limited, it is unclear whether virus found in feces may be capable of causing COVID-19. There has not been a confirmed report of the virus spreading from feces to humans. While plausible, it is not yet certain how well the virus is able to survive in water and wastewater, or whether a person exposed to untreated wastewater or sewerage can contract the infection. SARSCoV-2 may potentially enter wastewater systems through nasal secretions (e.g. due to the blowing of one's nose and subsequent flushing of tissues). Similar coronaviruses have persisted in water, urine, feces and wastewater for periods up to 2 days at $20{ }^{\circ} \mathrm{C}, 4$ days at $22{ }^{\circ} \mathrm{C}$ and 14 days at $4{ }^{\circ} \mathrm{C}$, in diarrheal stool samples with an alkaline $\mathrm{pH} .[183,184]$ However, conventional wastewater treatment methods adopted in most municipal drinking water plants that use filtration and disinfection should remove or inactivate any virus, including SARS-CoV-2.
As enveloped viruses, human coronaviruses have been shown to be more sensitive to chlorination, oxidant disinfection and ultraviolet light than other viruses with protein coats.[185] Transmission of the virus through properly designed and maintained sewage systems is a remote possibility. Beyond 'business as usual' no SARS-CoV-2-specific modifications are required.[180] Existing standard practices of wastewater treatment plant operations still apply and should be adequate in managing transmission risks to wastewater workers. It is important to dispose of greywater in drains connected to a septic system, sewer or in a soakaway pit. The latter should be fenced off within the health facility grounds to prevent tampering and to avoid possible exposure in case of overflow.[185] Recreational water is another concern, although no reports have been made of SARS-CoV-2 transmission through the water in pools or in water play areas.[186] Proper operation, disinfection and maintenance of these facilities should inactivate the virus in the water.[180]

Solid waste The COVID-19 pandemic is generating tons of medical waste and used gear contaminated with bodily fluids or other infectious materials. There is no evidence that direct, unprotected handling of health care or municipal solid waste has resulted in SARS-CoV-2 transmission.[185] Medical waste generated during COVID-19 care can be treated and safely disposed of the same way as regular medical waste.[187] Discarding medical waste carelessly into the environment might result in severe consequences, particularly surface and fresh water pollution. Care should be taken to limit direct exposure to solid waste using best management practices. Waste management operators working with very limited safety equipment such as scavengers and waste-pickers are at great risk of infection.[187]

Vector-borne transmission Although SARS-CoV-2 can be found at low levels in blood, transmission via insect bite remains a remote possibility until proven otherwise.[188] The situation is under surveillance and monitoring by the American Mosquito Control Association.[189]

There is no evidence to support that SARS-CoV-2 can be vector borne. Scientists are assessing the potential risk that vectors like mosquitoes pose in SARS-CoV-2 transmission. Members of Coronaviridae (SARS and MERS) are not transmitted through blood-feeding insects (mosquitoes, ticks, sandflies). The capacity of SARS-CoV-2 to infect and be transmitted by three widely distributed species of mosquito (Aedes aegypti, Aedes albopictus and Culex quinquefasciatus) has been experimentally investigated and the results showed that the virus is unable to replicate in these mosquitoes and therefore cannot be transmitted to people.[190]

Blood-borne transmission Nucleic acid from SARS-CoV-2 has been detected in many non-respiratory specimens including blood.[73,76,84,181] Although the role of blood in SARS-CoV-2 transmission remains uncertain, the risk merits caution and has resulted in some challenges to usual blood donation services. [191-193] The viral load peaks in the second week, but it is unknown if viremia occurs in pre-symptomatic or asymptomatic infection. $[193,194]$ The median duration of the virus in serum 
was 16 days and correlated with disease severity and patient age.[73,76] Generally, respiratory viruses are not transmitted through blood. The potential for SARS-CoV-2 transmission through blood or blood derivatives appears low since no transfusion-transmitted infection has been reported for SARSCoV-2 in recipients of platelets or red blood cell transfusions from donors diagnosed with SARS-CoV-2 or for the related coronaviruses SARS-CoV and MERS-CoV (the receptors did not develop COVID-19-related symptoms nor did they test positive for SARS-CoV-2).[195,196] Importantly, SARS-CoV-2 has been shown to attack the 1-beta chain of hemoglobin and capture the porphyrin to inhibit human heme metabolism. This diminishes hemoglobin binding capacity to oxygen, triggering resistant hypoxia coupled with very rapid multi-organ collapse in COVID-19 patients.[197]

Several studies have investigated pathogen inactivation and reduction technologies (PRTs) to completely eradicate the potential risk of coronavirus transmission via blood or blood products.[192] Since February 10, 2020, Wuhan Blood Center and all blood banks in Hubei province have tested blood donations for SARS-CoV-2 RNA.[192] Plasma samples from this bank that were positive for viral RNA from four asymptomatic donors were screened in real time and retrospectively back to January 25, 2020.[198] The European Center for Disease Prevention and Control (ECDC)[199] and American Association of Blood Banks (AABB)[200] conducted a rapid risk assessment of the SARS-CoV-2 outbreak and its impact on blood safety. In this context, they established a precautionary 21-28 days deferral of donation after potential exposure to a confirmed case, resolution of symptoms and completion of therapy in patients with confirmed COVID-19, or in those recently returned from an outbreak area.[199]

Apart from taking body temperature, screening questions for symptoms or potential exposure, active post-donation information gathering, and recalling and tracing infected donors, the ECDC, AABB, FDA and CDC do not currently recommend any specific measures for blood collection and testing protocols, since the risk for transfusion transmission of SARS-CoV-2 is still theoretical.[192] However, the safety of these actions is questionable in the face of unknown risk. [193] The New York Blood Center is closely monitoring the COVID-19 outbreak.[201]

Organ transplantation There is a risk of donor-derived SARSCoV-2 infection, either from living or deceased donors. [202] The ECDC has recommended SARS-CoV-2 testing for epidemiologically at-risk potential organ donors.[203] Transplant recipients are at high risk of infection from viruses since they require immunosuppressants. Considering the previous responses to similar viruses, SARS-CoV-2 may induce severe consequences in recipients. They are anticipated to have more intense and prolonged viral shedding, with potential secondary impacts on contacts and health care workers. Nevertheless, preliminary evidence from an Italian transplant center in Lombardy showed that immunosuppression did not increase the risk of severe COVID-19 disease. However, it was suggested that precautions were still merited, as severe clinical manifestations could be triggered by reactive innate immune responses.[204] On the other hand, kidney transplant patients with COVID-19 in London evolved to serious stages and the disease was associated with poor outcomes.[205] As more information surfaces, these risks require further clarifications before we are capable of drawing more solid conclusions.

To avoid severe consequences of SARS-CoV-2 infection on both the transplant community and the contacts of transplant patients, the American Society of Transplantation has put forward interim recommendations. Living donors are required to avoid disease outbreak areas for at least 14 days before donation and are monitored for symptoms and exposure history.

A 14-day deferral for elective organ donation is warranted for asymptomatic living donors with a recent history of travel to disease transmission areas or exposure to a person with known or suspected COVID-19. Deceased donors with known active COVID-19 are to be denied, whereas deceased donors with epidemiologic risks but without history of fever or respiratory illness or donors who have recovered from COVID-19 in the past are carefully considered for organs other than the lungs or intestine. Isolation procedures should be applied if a transplant is performed during a potential incubation period or in a country with endemic circulation of SARS-CoV-2. As more information becomes available, procedures related to transplantation must be updated.[202,203]

Hemodialysis Hemodialysis patients are in mandatory congregate settings, which compounds risk. Dialysis centers have become far more dangerous as SARS-CoV-2 spreads rapidly in the community. Several studies reported maintenance hemodialysis patients who contracted SARSCoV-2 infection, although the transmission could not be traced to the hemodialysis process.[206,207]

To anticipate this challenge and provide evidence-based guidance to patients, healthcare professionals and dialysis facilities, the American Society of Nephrology established a COVID-19 Response Team in conjunction with the CDC. [208,209] Preventive strategies must be implemented to minimize the risk of widespread dissemination of SARSCoV-2 in dialysis facilities, including education of staff and patients, careful disinfection, early recognition and screening for COVID-19 and separation of infected or symptomatic from non-infected patients.[210-212] Some dialysis organizations employ cohort models to identify epidemiologically at-risk patients and symptomatic or COVID-19-positive patients, transferring them to different facilities.[210]

Nosocomial transmission Many confirmed COVID-19 patients have been infected in healthcare facilities.[213-216] Based on a meta-analysis of 4 studies, the proportion of nosocomial infection with SARS-CoV-2 has been quite high, accounting for $44 \%$ of patients with COVID-19.[217] Indeed, early in the epidemic, hospital personnel did not know enough about the virus to take proper precautions, leading to inattentive prevention and control actions. Moreover, patients admitted to hospitals did not take any precautions or personal protection. Many unsuspicious COVID-19 cases were initially nursed in non-dedicated multi-bed wards, mingling and sharing common facilities with other patients.[218] 
Appropriate hospital control measures have been able to prevent nosocomial SARS-CoV-2 transmission. Contact tracing and surveillance did not result in COVID-19 cases among hospitalized patients or health care workers when a vigilant integrated infection control strategy was in place.[49,218-221] Influencing patient behavior to encourage them to take droplet and contact precautions, and applying social distancing within hospitals have been equally important in reducing nosocomial spread.[219] Interestingly, high-flow oxygen therapy $\geq 6 \mathrm{~L} / \mathrm{min}$ with a simple facemask posed a low risk of aerosol generation and did not result in secondary transmission[219] due to limited air leak through the side vents,[222,223] hence the neighboring patients were safe if they were kept at least one meter from the index patient. To increase safety during non-invasive ventilation, a helmet can be used as an interface if connected to the ventilator to avoid aerosolization.[224]

The "eagle-eyed observer" is another promising endeavor for minimizing SARS-CoV-2 nosocomial infection. In this context, an on-duty observer remotely monitors medical staff in real time and instructs for instant correction.[225,226] As a proactive infection control tool, this provides immediate solutions in negative pressure isolation wards at three stages (before medical worker entry, while in ward, and after leaving the isolation ward).

Health-care workers SARS-CoV-2 mimicked the 2003 SARS epidemic in producing alarming infection rates among healthcare workers (HCWs).[227,228] The virus attacked 2.0\%$29.0 \%$ of responding HCWs in China, Italy, Spain, USA and UK.[219, 229-232] Although some acquired the infection in the community, most contracted SARS-CoV-2 at their workplaces while providing direct patient care. Despite awareness of the potential of aerosol transmission through various therapeutic activities, inevitable exposure often occurred while performing AGPs.[219,229-232] HCWs have been therefore required to wear a full set of PPE and an N95 mask or equivalent gear while performing an AGP.[233] Of note, PPE could itself be a source of airborne contamination. In fact, Liu at Wuhan University studied SARS-CoV-2 aerodynamics in Wuhan hospitals and found that it can be resuspended in the air when HCWs remove their PPE, clean floors and move through infected areas.[48] $\mathrm{HCW}$ should therefore receive continuous training on proper hygiene measures and PPE use.[49,221,234] Although access to PPE is prioritized for HCWs, shortages or equipment that was not up to standards was described in many settings.[234] WHO is working with governments, industry and the Pandemic Supply Chain Network to boost production and secure sufficient PPE.[235]

According to some reports, HCWs were more likely to get SARS-CoV-2 in the community, yet there have been few scientific reports specifically looking into this aspect.[236,237]

Travel The COVID-19 pandemic has imposed a global shutdown of borders, including international air travel.[238] Travel restrictions go beyond border control, as entry thermal and syndromic screening for all incoming travelers, a 14-day quarantine of healthy individuals, and complete travel bans from high-risk areas were introduced by more than 130 countries. $[239,240]$ Certainly, travelers departing from Wuhan before the
Spring Festival were the main infection source for other cities in China.[241,242] The CDC advises avoiding all nonessential travel to all global destinations. Conversely, prolonged border closures goes against WHO's recommendation to avoid unnecessary restrictions on international traffic and trade.[240] Indeed, travel bans may interrupt deliveries of needed aid and technical support. [238] After careful risk assessment, restrictions must be revised regularly as the situation evolves to remain responsive in both measures and duration of the risk to public health.[243]

Travel restriction has often been debated. Understanding the implications of SARS-CoV-2 transmission is crucial for the formulation of containment strategies.[244] Airport screening was successful in identifying and blocking importation of up to $50 \%$ of dengue or Ebola cases presenting with fever in Taiwan. $[245,246]$ However, in the ongoing COVID-19 pandemic, airport screening effectiveness was estimated to be very limited given the disease's extended incubation period (beyond 14 days), which can result in low predictive values at screening locations.[247] Asymptomatic cases in their incubation period or cases concealing fever during travel could escape border controls and become infectious later to seed local transmission in destination countries.[30,248,249] Moreover, syndromic screening generates a high overhead of travelers who screen positive but are uninfected with the pathogen of interest. $[250,251]$ A reliable screening test (RT-PCR) can detect symptomatic and asymptomatic COVID-19 cases but will not provide instantaneous results.[252]

Statistical modeling estimated a $70.4 \%$ reduction in COVID-19 global incidence after travel bans, and a 7\%-20\% reduced probability of major epidemics in all countries. However, travel bans secured only a few days of delay in the spread of the epidemic which will not substantially help meaningful prevention.[253,254]

The risk of contracting the virus on regularly traveled public transportation in major cities may outweigh the risk of contracting the disease through international travel if physical distancing is not maintained. Accordingly, the contribution of global travel restrictions is relatively small unless paired with public health interventions (early detection, disease surveillance, social distancing, hand washing, sanitation, selfisolation, quarantine and case management) to maximize reduction of transmissibility.

Mass gatherings Large events and mass gatherings (MGs) such as concerts, festivals, conferences or sporting events have been sources of infectious disease spread and responsible for exacerbating the scope of pandemics.[255-257] However, the scale of the problem has declined over decades as better public health measures have been applied.[256,258,259] Behaviors in MGs like talking, sharing food or drinks and long periods of close sitting or standing can facilitate disease transmission. The role of MGs in SARS-CoV-2 transmission could be significant given the relatively high $R_{0}$.[260] In response to the COVID-19 pandemic and in line with social distancing guidance, government officials and responsible organizations in many countries have made decisions to cancel or postpone planned events.[261,263] Timing of restrictions should come closer to peaks in the epidemic and continue as 
long as the transmission fails to decrease.[260] Schools are closed and distance learning is being adopted. Venues where people congregate for nonessential purposes such as gyms, pools, movies, museums or recreation are closed. On the other hand, supermarkets, service stations, clinics, pharmacies, banking and other essential gathering services remain open. $[262,264]$ MG cancellation or suspension is critical to pandemic mitigation. [257,265] A large body of research in this area is based on modeling studies[257] and case reports, including the COVID-19 outbreaks on the Diamond Princess cruise ship[30] and carnivals in Latin America.[266]

Adherence to MG restrictions will aid emergency services and alleviate the burden on public health. Nevertheless, restrictions on MGs should be decided on the basis of context-specific risk assessment and clear rationale, bearing in mind their socioeconomic impacts and effects on the future wellbeing of communities. $[258,263]$

Refugees and migrants Given how quickly SARS-CoV-2 is spreading, it will inevitably establish a foothold in refugee and migrant communities and within internally-displaced settlements.[267] The risk is compounded by overcrowded living arrangements and the immense barriers to accessing healthcare services and sanitation facilities commonly found in these communities. Border closures and movement restrictions will likely increase as containment measures for COVID-19 control intensify, which will block refugee rights to seek asylum and humanitarian aid, particularly after the UN suspension of resettlement procedures.[267,268] The COVID-19 pandemic could devastate migrant populations without immediate action and enormous global support. For example, almost half the refugees in the Ellwangen refugee camp in Baden-Wurttemberg tested positive for SARS-CoV-2 (250 confirmed cases), and these individuals were forced to share facilities with everyone else. Moreover, about $80 \%$ of refugees live in low- and middleincome countries with compromised healthcare systems and reduced epidemic management capacity.[268] WHO calls on preparedness plans to consider refugees and address their needs in order to ensure no one will be left behind. Its proposed framework guides risk assessment, case management protocols, rapid deployment of outbreak response teams and linguistically accessible information about COVID-19.[269,270]

Homelessness Homeless people live in environments that are conducive to disease spread.[271] They live in congregate settings (tents, shelters or halfway houses, encampments, abandoned buildings, train or bus stations, tunnels) with shortage of basic needs and hygiene supplies. Moreover, homeless individuals engage in high rates of substance abuse, have poor health status, and experience 5-10 times higher all-cause mortality than the general population.[271,272] People experiencing homelessness are at a catastrophic risk of infection during the community spread of SARS-CoV-2. [273] More particularly, mentally-ill homeless individuals will not be able to cope with the situation in recognizing and responding to the threat of infection.[273] These circumstances challenge attempts to stem SARS-CoV-2 in countries with sizable unsheltered populations.[273,274] As cities impose a lockdown to prevent SARS-CoV-2 transmission, emergency preparedness plans to protect and accommodate people experiencing homelessness are few. In the USA, in response to the COVID-19 crisis, action is being taken to relocate many of homeless people to hotels. In fact, homelessness requires additional measures and resources. In the USA, the CDC has issued interim guidance to support response planning by emergency management and public health authorities in order to respond to the needs of homeless populations in the face of the epidemic.[275]

Drug addiction COVID-19 could hit populations with substance abuse disorders (SUDs) particularly hard.[276] Very little is known about SARS-CoV-2 and its intersection with SUDs. However, people who use drugs (PWUD) including opioids, methamphetamine or cannabis, might face an increased risk of COVID-19 and its more serious complications given their effects on cardiopulmonary health as well as on the immune system. [276] Compromised breathing is the main life-threatening effect of opioid abuse, which can be further aggravated by COVID-19 and manifest as an overdose.[276,277]

The current public health crisis raises additional serious concerns for PWUDs. Indeed, recreational drug use often takes place within congregate settings where smoking or injecting equipment potentially contaminated with SARSCoV-2 are shared.[278] Prospects of self-quarantine and other public health restrictions may also disrupt regular access to syringe exchange services, medications and other needed support. Moreover, PWUDs experience housing instability and limited access to health care at higher rates than the rest of the population. Fear of stigmatization will create an additional barrier to treatment for COVID-19.[276]

Smoking and tobacco use Mounting evidence has attributed differences in COVID-19 prevalence and severity to smoking. [279-281] Two meta-analyses of relevant epidemiological studies conducted in China supported the argument that smoking is most likely associated with the negative progression and adverse outcomes of COVID-19.[282,283] Conversely, reports from several studies questioned the role of coexisting active smoking as a risk factor for COVID-19 pneumonia,[284] and even suggest a protective role.[285] In this regard, epidemiological data showed that smokers were underrepresented among COVID-19 patients, with no significant association between current smoking and severe disease.[94,286-288]

Interestingly, the prevalence of current smoking among hospitalized COVID-19 cases in China, France and the USA was low (approximately one third the anticipated prevalence when considering smoking prevalence in the general population). French researchers suggested that the nicotinic acetylcholine receptor (nAChR) plays a key role in the pathophysiology of SARS-CoV-2 infection and thus presents a target for its prevention and control. This legitimizes controlled use of nicotine to compete with SARS-CoV-2 binding to the nAChR. A therapeutic assay of nicotine patches against COVID-19 is planned to test this theory at Pitié-Salpêtrière hospital in Paris.[289]

Controversial inferences from the latest epidemiological studies should be interpreted with caution, given the limited available data and unadjusted results for other factors that may 
affect disease outcomes. In fact, smokers are likely to be more vulnerable to contracting COVID-19, as the act of smoking involves frequent hand to mouth contact. Moreover, preexisting lung damage puts smokers at a higher risk of serious lung illness such as pneumonia.[290]

The CDC suggests that COVID-19 has a case fatality rate of $6.3 \%$ for individuals with chronic respiratory disease, compared with $2.3 \%$ overall.[291] In waterpipe smoking, a single mouthpiece and hose are often shared among users in communal and social settings. In addition, the waterpipe apparatus is not cleaned between sessions, thus promoting the survival of contaminating microorganisms. These factors provide ample opportunity for SARS-CoV-2 and other infectious diseases to spread between users.[292] Likewise, vaping may also harm lung health. Emerging evidence suggests that exposure to aerosols from e-cigarettes causes lung injury and diminishes the ability to respond to infection.[293]

Imprisonment Detention environments are breeding grounds for infectious diseases.[294,295] Infection rates in prisons are fueled by overcrowding, poor ventilation, unsanitary facilities, high risk behaviors, deficient healthcare services and the weighting of security over public health concerns.[294-296] Moreover, prisoners have restricted access to common hygiene products containing ingredients usually deemed contraband, such as alcohol-based hand sanitizer.[295]

Alarming clusters of COVID-19-related deaths have erupted among incarcerated persons and prison staff.[297] Over 10 million people are incarcerated worldwide,[298] which makes prisons a worldwide flashpoint for the disease's spread.[299] The incarcerated population is at heightened risk for contracting COVID-19 as well as for developing severe disease-related complications due to normative multimorbidity and accelerated aging.[297,300]

The response to COVID-19 in prisons and other places of detention is challenging and requires a holistic approach. Government officials from many countries adopted measures for limited prisoner release to reduce the incidence of in-custody transmission.[297] However, release without a plan poses the risk of viral spread to the local general population. In this regard, WHO has issued prison-specific guidance for responding to COVID-19. It suggests: i) joint planning to integrate prison health in the overall public health response, ii) risk management to limit transmission and spread within and beyond prisons, formulating adequate prevention and control protocols for entry screening, personal protection, social distancing, environmental cleaning and disinfection, restriction of movement and limited access for visitors, iii) treatment, specialized care and isolation of cases and contacts and iv) facilitation of timely information sharing and establishment of close collaboration between healthcare and justice sectors.[301]

\section{CONCLUDING REMARKS}

Ferreting out scientifically sound information among inadequate, misinformed and controversial reports is a hard task. In consequence, an in-depth analysis of published scientific information is mandatory.

SARS-CoV-2 transmission and infection research is as essential today as it was at the beginning of the pandemic. The transition to a post-pandemic phase poses new problems regarding transmission, with profound social consequences. Undoubtedly, the post-pandemic period will highlight aspects of transmission that we are unable to foresee today. Until there is a safe and effective vaccine, and certainly, afterwards, research on the routes of transmission of the virus will remain a top priority. $-1 /$.

\section{REFERENCES}

1. Singhal T. A review of Coronavirus disease-2019 (COVID-19). Indian J Pediatr. 2020 Apr;87(4):281-6.

2. World Health Organization [Internet]. Geneva: World Health Organization; c2020. Coronavirus disease (COVID-2019). Situation reports. Coronoavirus disease (COVID-19) Weekly Epidemiological Update and Weekly Operational Update; [cited 2020 Aug 2]. Available at: https://www .who.int/emergencies/diseases/novel-coronavi rus-2019/situation-reports

3. van Doremalen $\mathrm{N}$, Bushmaker $\mathrm{T}$, Morris $\mathrm{DH}$, Holbrook MG, Gamble A, Williamson BN, et al. Aerosol and surface stability of SARS-CoV-2 as compared with SARS-CoV-1. N Engl J Med. 2020 Apr 16;382(16):1564-7.

4. Lesho E, Laguio-Vila M, Walsh E. Stability and Viability of SARS-CoV-2. N Engl J Med. 2020 May 14;382(20):1963-4.

5. Rubens JH, Karakousis PC, Jain SK. Stability and Viability of SARS-CoV-2. N Engl J Med. 2020 May 14;382(20):1962-3.

6. Schwartz KL, Kim J, Garber G. Stability and Viability of SARS-CoV-2. N Engl J Med. 2020 May 14;382(20):1963.

7. Helmers A. Stability and Viability of SARS-CoV-2. N Engl J Med. 2020 May 14;382(20):1964.

8. Petti S. Stability and Viability of SARS-CoV-2. N Engl J Med. 2020 May 14;382(20):1964-5.

9. Kampf G, Todt D, Pfaender S, Steinmann E. Persistence of coronaviruses on inanimate surfaces and their inactivation with biocidal agents. J Hosp Infect. 2020 Mar;104(3):246-51.

10. Grass G, Rensing C, Solioz M. Metallic copper as an antimicrobial surface. Appl Environ Microbiol. 2011 Mar;77(5):1541-7

11. Pastorino B, Touret F, Gilles M, de Lamballerie X Charrel RN. Evaluation of heating and chemical protocols for inactivating SARS-CoV-2. bioRxiv [Internet]. Yale: BMJ Yale; 2020 Apr 11 [cited 2020 Apr 20]. Available at: https://www.biorxiv .org/content/10.1101/2020.04.11.036855v1

12. Chin A, Chu J, Perera M, Hui K, Yen H-L, Chan $M$, et al. Stability of SARS-CoV-2 in different environmental conditions. medRxiv [Internet]. New York: Cold Spring Harbor Lab; 2020 Mar 27 [cited 2020 Apr 20]. Available at: https://www.medrxiv .org/content/10.1101/2020.03.15.20036673v2 .article-info

13. National Health Commission of the People's Republic of China [Internet]. Beijing: National Health Commission of the People's Republic of China; c2020. News. No evidence to suggest coronavirus will disappear in summer: WHO expert; 2020 Mar 7 [cited 2020 Mar 7]. Available at: http://en.nhc.gov.cn/2020-03/07/c_77446.htm

14. Bukhari Q, Jameel Y. Will coronavirus pandemic diminish by summer?[Internet].New York: SSRN; 2020 Mar 19 [cited 2020 Apr 20]. Available at: https://dx.doi.org/10.2139/ssrn.3556998

15. Wang J, Tang K, Feng K, Lin X, Lv W, Chen K, et al. High temperature and high humidity reduce the transmission of COVID-19 [Internet]. New York: SSRN; 2020 Mar 10 [cited 2020 Apr 20]. 33 p. Available at: https://papers.ssrn.com/sol3/ papers.cfm?abstract id $=3551767$

16. Sajadi MM, Habibzadeh P, Vintzileos A, Shokouhi $\mathrm{S}$, Miralles-Wilhelm F, Amoroso A. Temperature, humidity and latitude analysis to predict potentia spread and seasonality for COVID-19 [Internet] New York: SSRN; 2020 Mar 9 [cited 2020 Apr $20] .18$ p. Available at: http://dx.doi.org/10.2139/ ssrn.3550308

17. Lipsitch M. Seasonality of SARS-CoV-2: Will COVID-19 go away on its own in warmer weather? [Internet]. Boston: Harvard T.H. Chan School of Public Health; 2020 [cited 2020 Jul 31]; [about 2 p.]. Available at: https://ccdd.hsph.harvard .edu/will-covid-19-go-away-on-its-own-in-warmer -weather/

18. Wu Y, Jing W, Liu J, Ma Q, Yuan J, Wang $Y$, et al. Effects of temperature and humidity on the daily new cases and new deaths of COVID-19 in 166 countries. Sci Total Environ. 2020 Aug 10;729:139051. DOI: 10.1016/j.scitotenv.2020.139051.

19. Mecenas P, Bastos R, Vallinoto A, Normando $D$. Effects of temperature and humidity on the spread of COVID-19: A systematic review. medRxiv [Internet].New York: Cold Spring Harbor Lab; 2020 Apr 17 [cited 2020 Jul 15]. 31 p. Available at: https://www.medrxiv.org/content/10.1101 /2020.04.14.20064923v1.full.pdf+html 
20. Kowalski W, Walsh T, Petraitis V. 2020 COVID-19 Coronavirus Ultraviolet Susceptibility. Techniqual report. PurpleSun Inc2020 [Internet]. Berlin: ResearchGate; 2020 Mar [cited 2020 Jul 15]; [about 3 p.]. Available at: https://www.researchgate.net/publi cation/339887436_2020_COVID-19_Coro navirus Ultraviolet Susceptibility

21. Bianco A, Biasin M, Pareschi G, Cavalleri A, Cavatorta C, Fenizia C, et al. UV-C irradiation is highly effective in inactivating and inhibiting SARS-CoV-2 replication. medRxiv [Internet]. New York: Cold Spring Harbor Lab; 2020 Jun 23 [cited 2020 Jul 15]. Available at: https://www.medrxiv .org/content/10.1101/2020.06.05.20123463v2

22. Health Europe [Internet]. Congleton (UK): Pan European Networks Ltd; c2018. Infection Control News. Breakthrough ultraviolet light development could help kill COVID-19 virus; 2020 Jun 2 [cited 2020 Aug 2]; [about 2 p.]. Available at: https:// www.healtheuropa.eu/breakthrough-ultraviolet -light-development-could-help-kill-covid-19-vi rus/100409/

23. Du Z, Xu X, Wu Y, Wang L, Cowling BJ, Meyers LA. Serial interval of COVID-19 among publicly reported confirmed cases. Emerg Infect Dis. 2020 Jun;26(6):1341-3.

24. Qian G, Yang N, Ma AHY, Wang L, Li G, Chen $X$, et al. COVID-19 Transmission within a family cluster by presymptomatic carriers in China. Clin Infect Dis. 2020 Jul 28;71(15):861-2.

25. Wei WE, Li Z, Chiew CJ, Yong SE, Toh MP, Lee VJ. Presymptomatic Transmission of SARSCoV-2-Singapore. MMWR Morb Mortal Wkly Rep. 2020 Apr 10;69(14):41-5.

26. Zhou F, Yu T, Du R, Fan G, Liu Y, Liu Z, et al. Clinical course and risk factors for mortality of adult in patients with COVID-19 in Wuhan, China: a retrospective cohort study. Lancet. 2020 Mar 28;395(10229):1054-62.

27. Liu WD, Chang SY, Wang JT, Tsai MJ, Hung CC Hsu $\mathrm{CL}$, et al. Prolonged virus shedding even after seroconversion in a patient with COVID-19. J Infect. Epub 2020 Apr 10.

28. Zhou B, She J, Wang Y, Ma X. The duration of viral shedding of discharged patients with severe COVID-19. Clin Infect Dis. 2020 Apr 17. pii: ciaa451. DOI: 10.1093/cid/ciaa451. [Epub ahead of print]

29. Li Q, Guan X, Wu P, Wang X, Zhou L, Tong Y, et al. Early transmission dynamics in Wuhan, China, of Novel Coronavirus-Infected Pneumonia. N Engl J Med. 2020 Mar 26;382(13):1199-207.

30. Dahl E. Coronavirus (Covid-19) outbreak on the cruise ship Diamond Princess. Int Marit Health. 2020;71(1):5-8

31. Kucharski AJ, Russell TW, Diamond C, Liu Y, Edmunds J, Funk S, et al. Early dynamics of transmission and control of COVID-19: a mathematical modelling study. Lancet Infect Dis. 2020 May;20(5):553-8. Epub 2020 Mar 11.

32. Liu Y, Gayle AA, Wilder-Smith A, Rocklöv J. The reproductive number of COVID-19 is higher compared to SARS coronavirus. J Travel Med. 2020 Mar 13;27(2).

33. Sanche $\mathrm{S}$, Lin $\mathrm{YT}, \mathrm{Xu} \mathrm{C}$, Romero-Severson $\mathrm{E}$ Hengartner N, Ke R. High Contagiousness and rapid spread of Severe Acute Respiratory Syndrome Coronavirus 2. Emerg Infect Dis. 2020 Jul 7;26(7):1470-7.

34. Yuan J, Li M, Lv G, Lu ZK. Monitoring transmissibility and mortality of COVID-19 in Europe. Int J Infect Dis. 2020 Jun 95:311-5. Epub 2020 Mar 28

35. Cole EC, Cook CE. Characterization of infectious aerosols in health care facilities: an aid to effective engineering controls and preventive strategies. Am J Infect Control. 1998 Aug;26(4):453-64.

36. Duguid JP. The size and the duration of aircarriage of respiratory droplets and droplet- nuclei. J Hyg (Lond). 1946 Sep;44(6):471-9

37. Hamburger M Jr, Robertson OH. Expulsion of group A hemolytic streptococci in droplets and droplet nuclei by sneezing, coughing and talking Am J Med. 1948 May;4(5):690-701.

38. Loudon RG, Roberts RM. Relation between the airborne diameters of respiratory droplets and the diameter of the stains left after recovery. Nature. 1967 Jan 7;213(5071):95-6.

39. Yang $\mathrm{C}, \mathrm{Ma}$ QY, Zheng $\mathrm{YH}$, Yang YX. [Transmission routes of 2019-novel coronavirus (2019nCoV)]. Zhonghua Yu Fang Yi Xue Za Zhi. 2020 Apr 6;54(4):374-7. Chinese.

40. Fennelly KP. Particle sizes of infectious aerosols: implications for infection control. Lancet Respir Med. 2020 July 24;8(9):914-24.

41. Somsen GA, van Rijn C, Kooij S, Bem RA, Bonn D. Small droplet aerosols in poorly ventilated spaces and SARS-CoV-2 transmission. Lance Respir Med. 2020 Jul;8(7):658-9.

42. Lewis D. Is the coronavirus airborne? Experts can't agree. Nature. 2020 Apr;580(7802):175.

43. Medical Xpress [Internet]. Douglas (UK): Science X; c2011-2020. Diseases, Conditions, Syndroms. How Important Is Speech in Transmitting Coronavirus?; 2020 Apr 3 [cited 2020 May10] [about 2 p.]. Available at: https://medicalxpress .com/news/2020-04-important-speech-transmit ting-coronavirus.html

44. Rapid Expert Consultation on the Possibility of Bioaerosol Spread of SARS-CoV-2 for the COVID-19 Pandemic [Internet]. Washington, D.C.: National Academies of Sciences, Engineering, and Medicine; 2020 Apr 1 [cited 2020 May 10]. 3 p. Available at: https://www.nap.edu/ catalog/25769/rapid-expert-consultation-on-the -possibility-of-bioaerosol-spread-of-sars-cov-2 -for-the-covid-19-pandemic-april-1-2020

45. Bourouiba L. Turbulent gas clouds and respiratory pathogen emissions: potential implications for reducing transmission of COVID-19. JAMA. 2020 Mar 26. DOI: 10.1001/jama.2020.4756

46. Guo ZD, Wang ZY, Zhang SF, Li X, Li L, Li C, et al. Aerosol and surface distribution of severe acute respiratory syndrome coronavirus 2 in hospital wards, Wuhan, China, 2020. Emerg Infect Dis. 2020 Jul;26(7):1583-91.

47. Santarpia JL, Rivera DN, Herrera V, Morwitzer MJ, Creager H, Santarpia GW, et al. Transmission potential of SARS-CoV-2 in viral shedding observed at the University of Nebraska Medical Center. medRxiv [Internet]. New York: Cold Spring Harbor Lab; 2020 Jun 3 [cited 2020 Jun 10]. 12 p. Available at: https://www.medrxiv.org/ content/10.1101/2020.03.23.20039446v2.full.pdf

48. Liu Y, Ning Z, Chen Y, Guo M, Liu Y, Gali NK, et al. Aerodynamic characteristics and RNA concentration of SARS-CoV-2 aerosol in Wuhan hospitals during COVID-19 outbreak. bioRxiv [Internet]. New York: Cold Spring Harbor Lab 2020 Mar 10 [cited 2020 Mar 22]. Available at: https://www.biorxiv.org/content/10.1101/2020.03 $.08 .982637 \mathrm{~V} 1$

49. Cheng VCC, Wong S-C, Chen JHK, Yip CCY, Chuang VWM, Tsang OTY, et al. Escalating infection control response to the rapidly evolving epidemiology of the coronavirus disease 2019 (COVID-19) due to SARS-CoV-2 in Hong Kong. Infect Control Hosp Epidemiol. 2020 May:41(5):493-8.

50. Ong SWX, Tan YK, Chia PY, Lee TH, Ng OT Wong MSY, et al. Air, surface environmental, and personal protective equipment contamination by Severe Acute Respiratory Syndrome Coronavirus 2 (SARS-CoV-2) from a symptomatic patient. JAMA. 2020 Mar 4. DOI: 10.1001/ jama.2020.3227.

51. Faridi S, Niazi S, Sadeghi K, Naddafi K, Yavarian J, Shamsipour M, et al. A field indoor air mea- surement of SARS-CoV-2 in the patient rooms of the largest hospital in Iran. Sci Total Environ. 2020 Jul 10;725:138401. Epub 2020 Apr 6

52. World Health Organization [Internet]. Geneva: World Health Organization; c2020. Newsroom. Modes of transmission of virus causing COVID-19: implications for IPC precaution recommendations; 2020 Mar 29 [cited 2020 Apr 26]; [about 5 p.]. Available at: https://www.who int/news-room/commentaries/detail/modes-of -transmission-of-virus-causing-covid-19-implica tions-for-ipc-precaution-recommendations

53. To KK, Tsang OT, Chik-Yan Yip C, Chan $\mathrm{KH}$, Wu TC, Chan JMC, et al. Consistent detection of 2019 novel coronavirus in saliva. Clin Infect Dis [Internet]. 2020 Jul 28 [cited 2020];71(15):841-3. Available at: https://www.ncbi.nlm.nih.gov/pmc/articles/ pmid/32047895/

54. New insights into the transmissibility of the virus. Berlin: BioValley; 2020.

55. Setti L, Passarini F, De Gennaro G, Barbieri P, Perrone MG, Borelli M, et al. Airborne transmission route of COVID-19: why 2 meters/ 6 feet of inter-personal distance could not be enough. Int J Environ Res Public Health. 2020 Apr 23;17(8).

56. Zhang R, Li Y, Zhang AL, Wang Y, Molina MJ. Identifying airborne transmission as the dominant route for the spread of COVID-19. Proc Natl Acad Sci U S A. 2020 Jun 30;117(26):14857-63.

57. Setti L, Passarini F, De Gennaro G, Barbieri P, Perrone MG, Piazzalunga $A$, et al. The potential role of particulate matter in the spreading of COVID-19 in Northern Italy: first evidencebased research hypotheses. medRxiv [Internet]. New York: Cold Spring Harbor Lab;2020 Apr 17 [cited 2020 May 20]. Available at: https://www.medrxiv.org/content/10.1101/2020.0 4.11.20061713v1

58. World Health Organization [Internet]. Geneva: World Health Organization; c2020. Newsroom. Transmission of SARS-CoV-2: implications for infection prevention precautions; 2020 Jul 9 [cited 2020 Jul 31]; [about 10 p.]. Available at: https://www who.int/news-room/commentaries/ detail/transmission-of-sars-cov-2-implications -for-infection-prevention-precautions

59. Pancic F, Carpentier DC, Came PE. Role of infectious secretions in the transmission of rhinovirus. J Clin Microbiol. 1980 Oct:12(4):567-71.

60. Special Expert Group for Control of the Epidemic of Novel Coronavirus Pneumonia of the Chinese Preventive Medicine Association. [An update on the epidemiological characteristics of novel coronavirus pneumonia COVID-19]. Zhonghua Liu Xing Bing Xue Za Zhi. 2020 Feb 10;41(2):13944. Chinese.

61. Hamzelou J. Should you disinfect your online shopping? New Sci. 2020 Apr 4;245(3276):12.

62. New Group of Experts on the prevention and control of Chinese Preventive Medicine Association coronavirus pneumonia. The latest understanding of the epidemiological characteristics of pneumonia novel coronavirus. Chinese J Epidemiol. 2020.

63. Hamming I, Timens $\mathrm{W}$, Bulthuis ML, Lely AT, Navis G, van Goor H. Tissue distribution of ACE2 protein, the functional receptor for SARS coronavirus. A first step in understanding SARS pathogenesis. J Pathol. 2004 Jun;203(2):631-7.

64. Xu H, Zhong L, Deng J, Peng J, Dan H, Zeng X et al. High expression of ACE2 receptor of 2019nCoV on the epithelial cells of oral mucosa. Int $\mathrm{J}$ Oral Sci. 2020 Feb 24;12(1):8.

65. Zhang $\mathrm{H}$, Kang Z, Gong H, Xu D, Wang J, Li Z, et al. The digestive system is a potential route of 2019-nCov infection: a bioinformatics analysis based on single-cell transcriptomes. bioRxiv [Internet]. New York: Cold Spring Harbor Lab; 
2020 Jan 31 [cited 2020 Feb 19]. Available at: https://www.biorxiv.org/content/10.1101/2020.01 30.927806v1

66. Sahu KK, Mishra AK, Lal A. COVID-2019: update on epidemiology, disease spread and management. Monaldi Arch Chest Dis. 2020 Apr 16;90(1).

67. Xiao F, Tang M, Zheng X, Liu Y, Li X, Shan $H$. Evidence for gastrointestinal infection of SARS-CoV-2. Gastroenterology. 2020 May;158 (6):1831-3

68. Kotfis K, Skonieczna-Zydecka K. COVID-19: gastrointestinal symptoms and potential sources of 2019-nCoV transmission. Anaesthesiol Intensive Ther. 2020;52(2):172-3

69. Gu J, Han B, Wang J. COVID-19: Gastrointestinal manifestations and potential fecaloral transmission. Gastroenterology. 2020 May;158(6):1518-9.

70. World Health Organization. Report of the WHOChina Joint Mission on Coronavirus Disease 2019 (COVID-19) [Internet]. Geneva: World Health Organization; 2020 Feb 16-24 [cited 2020 Apr 27]. Available at: https://www.who. int/docs/defaultsource/coronaviruse/who-china -joint-mission-on-covid-19-final-report.pdf

71. Yong Z, Cao C, Shuangli Z, Chang S, Dongyan W, Jingdong S, et al. Isolation of 2019-nCoV from a Stool Specimen of a Laboratory-Confirmed Case of the Coronavirus Disease 2019 (COVID-19). China CDC Weekly. 2020;2(8):123-4.

72. Pan $Y$, Zhang D, Yang $P$, Poon LLM, Wang Q. Viral load of SARS-CoV-2 in clinical samples. Lancet Infect Dis. 2020 Apr;20(4):411-2.

73. Zheng S, Fan J, Yu F, Feng B, Lou B, Zou Q, et al. Viral load dynamics and disease severity in patients infected with SARS-CoV-2 in Zhejiang province, China, January-March 2020: retrospective cohort study. BMJ. 2020 Apr 21;369:m1443.

74. Cheung KS, Hung IFN, Chan PPY, Lung KC, Tso E, Liu R, et al. Gastrointestinal manifestations of SARS-CoV-2 infection and virus load in fecal samples from the Hong Kong cohort and systematic review and meta-analysis. Gastroenterology. 2020 Jul;159(1):81-95.

75. Bulut C, Kato Y. Epidemiology of COVID-19. Turk J Med Sci. 2020 Apr 21:50(SI-1):563-70.

76. Chen W, Lan Y, Yuan X, Deng X, Li Y, Cai X, et al. Detectable 2019-nCoV viral RNA in blood is a strong indicator for the further clinical severity. Emerg Microbes Infect. 2020 Feb 26;9(1):469-73.

77. Holshue ML, DeBolt C, Lindquist S, Lofy $\mathrm{KH}$, Wiesman J, Bruce $\mathrm{H}$, et al. First case of 2019 novel coronavirus in the United States. New Engl J Med. 2020 Mar 5;382(10):929-30.

78. Zhang J, Wang S, Xue Y. Fecal specimen diagnosis 2019 novel coronavirus-infected pneumonia. J Med Virol. 2020 Jun;92(6):680-2.

79. Yeo C, Kaushal S, Yeo D. Enteric involvement of coronaviruses: is faecal-oral transmission of SARS-CoV-2 possible? Lancet Gastroenterol Hepatol. 2020 Apr;5(4):335-7.

80. Nouri-Vaskeh M, Alizadeh L. Fecal transmission in COVID-19: a potential shedding route. J Med Virol. 2020 Apr 1. DOI: 10.1002/jmv.25816. [Epub ahead of print]

81. Chen $Y$, Chen L, Deng $Q$, Zhang G, Wu K, Ni $\mathrm{L}$, et al. The presence of SARS-CoV-2 RNA in the feces of COVID-19 patients. J Med Virol. 2020 Jul;92(7):833-40.

82. Wu Y, Guo C, Tang L, Hong Z, Zhou J, Dong X, et al. Prolonged presence of SARS-CoV-2 viral RNA in faecal samples. Lancet Gastroenterol Hepatol. 2020 May;5(5):434-5

83. Xiao F, Sun J, Xu Y, Li F, Huang X, Li H, et al Infectious SARS-CoV-2 in feces of patient with severe COVID-19. Emerg Infect Dis. 2020 Aug;26(8):1920-2.

84. Wang W, Xu Y, Gao R, Lu R, Han K, Wu G, et al. Detection of SARS-CoV-2 in different types of clinical specimens. JAMA. 2020 Mar 11. DOI: 10.1001/jama.2020.3786. [Epub ahead of print]

85. Chan WM, Yuen KS, Fan DS, Lam DS, Chan PK, Sung JJ. Tears and conjunctival scrapings for coronavirus in patients with SARS. Br J Ophthalmol. 2004 Jul;88(7):968-9.

86. Lu CW, Liu XF, Jia ZF. 2019 nCoV transmission through the ocular surface must not be ignored. Lancet. 2020 Feb 22;395(10224):e39.

87. Seah I, Agrawal R. Can the Coronavirus disease 2019 (COVID-19) affect the eyes? A review of Coronaviruses and ocular implications in humans and animals. Ocul Immunol Inflamm. 2020 Apr 2;28(3):391-5.

88. Colavita F, Lapa D, Carletti F, Lalle E, Bordi L, Marsella $P$, et al. SARS-CoV-2 isolation from ocular secretions of a patient with COVID-19 in Italy with prolonged viral RNA detection. Ann Intern Med. 2020 Aug 4;173(3):242-3.

89. Chen L, Liu M, Zhang Z, Qiao K, Huang T, Chen $M$, et al. Ocular manifestations of a hospitalised patient with confirmed 2019 novel coronavirus disease. Br J Ophthalmol. 2020 Jun;104(6):748-51.

90. Cheema M, Aghazadeh $H$, Nazarali S, Ting A, Hodges J, McFarlane A, et al. Keratoconjunctivitis as the initial medical presentation of the novel coronavirus disease 2019 (COVID-19): a case report. Can J Ophthalmol. 2020 Aug;55(4):e125-9.

91. Hong N, Yu W, Xia J, Shen Y, Yap M, Han W. Are ocular symptoms common in patients with COVID-19? [Internet]. New York: SSRN; 2020 Apr 1 [cited 2020 May 27]. 38 p. Available at: https:// papers.ssrn.com/sol3/papers.cfm?abstract id $=3559539$

92. Liang $\mathrm{L}, \mathrm{Wu} \mathrm{P}$. There may be virus in conjunctival secretion of patients with COVID-19. Acta Ophthalmol. 2020 May;98(3):223. DOI: 10.1111/ aos.14413.

93. Wu P, Duan F, Luo C, Liu Q, Qu X, Liang L, et al. Characteristics of ocular findings of patients with Coronavirus disease 2019 (COVID-19) in Hubei Province, China. JAMA Ophthalmol. 2020 Mar 31. DOI: 10.1001/jamaophthalmol.2020.1291 [Epub ahead of print]

94. Guan WJ, Ni ZY, Hu Y, Liang WH, Ou CQ, He JX, et al. Clinical characteristics of Coronavirus disease 2019 in China. N Engl J Med. 2020 Apr 30;382(18)1708-20.

95. Peng $\mathrm{Y}$, Zhou $\mathrm{YH}$. Is novel coronavirus disease (COVID-19) transmitted through conjunctiva? J Med Virol. 2020 Mar 16. DOI: 10.1002/ jmv.25753. [Epub ahead of print]

96. Kuo IC. A Rashomon moment? Ocular involvement and COVID-19. Ophthalmology. 2020 Jul;127(7):984-5.

97. Xia J, Tong J, Liu M, Shen Y, Guo D. Evaluation of coronavirus in tears and conjunctival secretions of patients with SARS-CoV-2 infection. J Medical Virol. 2020 Jun;92(6):589-94.

98. Jun ISY, Anderson DE, Kang AEZ, Wang L-F Rao $P$, Young BE, et al. Assessing viral shedding and infectivity of tears in coronavirus disease 2019 (COVID-19) patients. Ophthalmology. 2020 Jul;127(7):977-9

99. Jones L, Walsh K, Willcox M, Morgan P, Nichols J. The COVID-19 pandemic: Important considerations for contact lens practitioners. Cont Lens Anterior Eye. 2020 Jun;43(3):196-203.

100. Dong L, Tian J, He S, Zhu C, Wang J, Liu C, et al. Possible vertical transmission of SARS-CoV-2 from an infected mother to her newborn. JAMA. 2020 Mar 26.DOI: 10.1001/jama.2020.4621. [Epub ahead of print]

101. Zeng L, Xia S, Yuan W, Yan K, Xiao F, Shao J, et al. Neonatal early-onset infection with SARS-CoV-2 in 33 neonates born to mothers with COVID-19 in Wuhan, China. JAMA Pediatr. 2020 Mar 26. DOI: 10.1001/jamapediatrics.2020.0878. [Epub ahead of print]

102. Zeng $\mathrm{H}, \mathrm{Xu} \mathrm{C}$, Fan J, Tang $\mathrm{Y}$, Deng Q, Zhang $W$, et al. Antibodies in infants born to mothers with COVID-19 pneumonia. JAMA. 2020 Mar 26. DOI: 10.1001/jama.2020.4861.

103. Alzamora MC, Paredes T, Caceres D, Webb CM, Valdez LM, La Rosa M. Severe COVID-19 during pregnancy and possible vertical transmission. Am J Perinatol. 2020 Jun;37(8):861-5.

104. Kimberlin DW, Stagno S. Can SARS-CoV-2 infection be acquired in utero?: more definitive evidence is needed. JAMA. 2020 Mar 26. DOI: 10.1001/jama.2020.4868.

105. Ashraf MA, Keshavarz $P$, Hosseinpour $P$, Erfani A, Roshanshad A, Pourdast A, et al. Coronavirus Disease 2019 (COVID-19): asystematic review of pregnancy and the possibility of vertical transmission. J Reprod Infertil. 2020 JulSep;21(3):157-68.

106. Zhu H, Wang L, Fang C, Peng S, Zhang L, Chang G, et al. Clinical analysis of 10 neonates born to mothers with 2019-nCoV pneumonia. Transl Pediatr. 2020 Feb;9(1):51-60.

107. Li Y, Zhao R, Zheng S, Chen X, Wang J, Sheng $X$, et al. Lack of vertical transmission of Severe Acute Respiratory Syndrome Coronavirus 2, China. Emerg Infect Dis. 2020 Jun;26(6):1335-6.

108. Chen H, Guo J, Wang C, Luo F, Yu X, Zhang $W$, et al. Clinical characteristics and intrauterine vertical transmission potential of COVID-19 infection in nine pregnant women: a retrospective review of medical records. Lancet. 2020 Mar 7;395(10226):809-15.

109. Schwartz DA. An Analysis of 38 Pregnant women with COVID-19, their newborn infants, and maternal fetal transmission of SARS-CoV-2: maternal Coronavirus infections and pregnancy outcomes. Arch Pathol Lab Med. 2020 Mar 17.DOI: 10.5858/ arpa.2020-0901-SA. [Epub ahead of print]

110. Zhang L, Jiang $Y$, Wei $M$, Cheng BH, Zhou XC, Li $\mathrm{J}$, et al. [Analysis of the pregnancy outcomes in pregnant women with COVID-19 in Hubei Province]. Zhonghua Fu Chan Ke Za Zhi. 2020 Mar 25;55(3):166-71. Chinese.

111. Rasmussen SA, Smulian JC, Lednicky JA, Wen TS, Jamieson DJ. Coronavirus Disease 2019 (COVID-19) and pregnancy: what obstetricians need to know. Am J Obstet Gynecol. 2020 May;222(5):415-26.

112. Karimi-Zarchi $M$, Neamatzadeh $H$, Dastgheib SA, Abbasi H, Mirjalili SR, Behforouz A, et al. Vertical transmission of Coronavirus disease 19 (COVID-19) from infected pregnant mothers to neonates: a review. Fetal Pediatr Pathol. 2020 Jun;39(3):246-50.

113. Yang $\mathrm{H}$, Wang $\mathrm{C}$, Poon LC. Novel coronavirus infection and pregnancy. Ultrasound Obstetrics Gynecol. 2020 Apr;55(4):435-7.

114. Bouthry E, Picone O, Hamdi G, Grangeot-Keros L, Ayoubi JM, Vauloup-Fellous C. Rubella and pregnancy: diagnosis, management and outcomes. Prenat Diagn. 2014 Dec;34(13):1246-53.

115. Schmid MB, Fontijn J, Ochsenbein-Kölble N Berger C, Bassler D. COVID-19 in pregnant women. Lancet Infect Dis. 2020 Jun;20(6):653. DOI: 10.1016/S1473-3099(20)30175-4.

116. Ferrazzi E, Frigerio $L$, Savasi $V$, Vergani $P$, Prefumo $F$, Barresi $S$, et al. Vaginal delivery in SARS-CoV-2 infected pregnant women in Northern Italy: a retrospective analysis. BJOG. 2020 Apr 27. DOI: 10.1111/1471-0528.16278. [Epub ahead of print]

117. Iqbal SN, Overcash $R$, Mokhtari $N$, Saeed $H$, Gold S, Auguste T, et al. An uncomplicated delivery in a patient with Covid-19 in the United States. N Engl J Med. 2020 Apr 16;382(16):e34. 
118. Xiong X, Wei H, Zhang Z, Chang J, Ma X, Gao X, et al. Vaginal delivery report of a healthy neonate born to a convalescent mother with COVID19. J Med Virol. 2020 Apr 10. DOI: 10.1002/jmv.25857.

119. Grob R, Conzelmann C, Müller JA, Stenge S, Steinhart K, Kirchhoff F, et al. Detection of SARS-CoV-2 in human breastmilk. Lancet. 2020 Jun 6;395(10239):1757-8

120. World Health Organization [Internet]. Geneva: World Health Organization; c2020. Newsroom. Breastfeeding and COVID-19; 2020 Jun 23 [cited 2020 July 31]; [about 3 p.]. Available at: https://www.who.int/news-room/commentaries/ detail/breastfeeding-and-covid-19

121. Centers for Disease Control and Prevention (CDC) [Internet]. Atlanta: Centers for Disease Control and Prevention (CDC); c2020. Breastfeeding. Coronavirus disease (COVID-19) and breastfeeding; 2020 [cited 2020 Apr 28]. Available at: https://www.cdc.gov/breastfeeding/breastfeed ing-special-circumstances/maternal-or-infant -illnesses/covid-19-and-breastfeeding.html

122. Hussein J. COVID-19: What implications for sexual and reproductive health and rights globally? Sex Reprod Health Matters. 2020 Dec;28(1):1746065. DOI: 10.1080/ 26410397.2020.1746065.

123. Pan F, Xiao X, Guo J, Song Y, Li H, Patel DP, et al. No evidence of severe acute respiratory syndrome-coronavirus 2 in semen of males recovering from coronavirus disease 2019. Fertil Steril. 2020 Jun;113(6):1135-9.

124. Song C, Wang Y, Li W, Hu B, Chen G, Xia P, et al. Detection of 2019 novel coronavirus in semen and testicular biopsy specimen of COVID-19 patients. medRxiv [Internet]. New York: Cold Spring Harbor Lab; 2020 Apr 10 [cited 2020 May 20]. Available at: https://www.medrxiv.org/content/10 1101/2020.03.31.20042333v2.full.pdf

125. Cui P, Chen Z, Wang T, Dai J, Zhang J, Ding $\mathrm{T}$, et al. Clinical features and sexual transmission potential of SARS-CoV-2 infected female patients: a descriptive study in Wuhan, China. medRxiv [Internet]. New York: Cold Spring Harbor Lab; 2020 Feb 27 [cited 2020 Mar 15]. Available at: https://www.medrxiv.org/content/10.1101 /2020.02.26.20028225v1.full.pdf

126. Li D, Jin M, Bao P, Zhao W, Zhang S. Clinica characteristics and results of semen tests among men with coronavirus disease 2019. JAMA Netw Open. 2020 May 1;3(5):e208292.

127. Patri A, Gallo L, Guarino M, Fabbrocini G Sexual transmission of severe acute respiratory syndrome coronavirus 2 (SARS-CoV-2): a new possible route of infection? J Am Acad Dermatol. 2020 Jun;82(6):e227. DOI: 10.1016/j. jaad.2020.03.098.

128. Wang Z, Xu X. scRNA-seq profiling of human testes reveals the presence of the ACE2 receptor, a target for SARS-CoV-2 infection in Spermatogonia, Leydig and Sertoli cells. Cells. 2020 Apr 9;9(4):pii: E920.

129. Murdoch DR, French NP. COVID-19: another infectious disease emerging at the animal-human interface. N Z Med J. 2020 Feb 21;133(1510):12-5

130. Salata C, Calistri A, Parolin C, Palù G. Coronaviruses: a paradigm of new emerging zoonotic diseases. Pathog Dis. 2019 Dec 12;77(9). pii: ftaa006.DOI: 10.1093/femspd/ftaa006.

131. Lee PI, Hsueh PR. Emerging threats from zoonotic coronaviruses-from SARS and MERS to 2019-nCoV. J Microbiol Immunol Infect. 2020 Jun;53(3):365-7.

132. Ji W, Wang W, Zhao X, Zai J, Li X. Cross-species transmission of the newly identified Coronavirus 2019-nCoV. J Med Virol. 2020 Apr;92(4):433-40.

133. Zhou $P$, Yang $X L$, Wang $X G$, Hu B, Zhang $L$, Zhang $W$, et al. A pneumonia outbreak associat- ed with a new coronavirus of probable bat origin Nature. 2020 Mar;579(7798):270-3.

134. Paraskevis D, Kostaki EG, Magiorkinis G Panayiotakopoulos G, Sourvinos G,Tsiodras S Full-genome evolutionary analysis of the novel corona virus (2019-nCoV) rejects the hypothesis of emergence as a result of a recent recombination event. Infect Genet Evol. 2020 Apr;79:104212. DOI: 10.1016/j.meegid.2020.104212.

135. Callaway E, Cyranoski D. Why snakes probably aren't spreading the new China virus. London: Springer Nature; 2020 Jan 23 [cited 2020 Apr 25]. Available at: https://www.nature.com/ articles/d41586-020-001808?fbclid=IwAR2Wh sY7rHjl86vgRpyiaUYQkvvKR9mjYrbI3LXBL8xo qJVhnGmr5d4MZiY

136. Gorbalenya AE, Baker SC, Baric RS, de Groot RJ, Drosten C, Gulyaeva AA, et al. Severe acute respiratory syndrome-related coronavirus-The species and its viruses, a statement of the Coronavirus Study Group. bioRxiv [Internet]. NewYork: Cold Spring Harbor Lab; 2020 Feb 11 [cited 2020 Mar 19]. Available at: https://www.biorxiv .org/content/10.1101/2020.02.07.937862v1

137. Lu R, Zhao X, Li J, Niu P, Yang B, Wu H, et al. Genomic characterisation and epidemiology of 2019 novel coronavirus: implications for virus origins and receptor binding. Lancet. $2020 \mathrm{Feb}$ 22;395(10224):565-74.

138. Zhu N, Zhang D, Wang W, Li X, Yang B, Song $\mathrm{J}$, et al. A novel Coronavirus from patients with pneumonia in China, 2019. N Engl J Med. 2020 Feb 20;382(8):727-33.

139. Ren LL, Wang YM, Wu ZQ, Xiang ZC, Guo L, $\mathrm{Xu} T$, et al. Identification of a novel Coronavirus causing severe pneumonia in human: a descriptive study. Chinese Med J (Engl). 2020 May 5;133(9):1015-24

140. Benvenuto D, Giovanetti M, Ciccozzi A, Spoto S, Angeletti S, Ciccozzi M. The 2019-new coronavirus epidemic: evidence for virus evolution. J Medi Virol. 2020 Apr;92(4):455-9.

141. Wan Y, Shang J, Graham R, Baric RS, Li F. Receptor Recognition by the novel Coronavirus from Wuhan: an analysis based on decade-long structural studies of SARS Coronavirus. J Virol. 2020 Mar 17;94(7). pii: e00127-20. DOI: 10.1128/JVI.00127-20.

142. Andersen KG, Rambaut A, Lipkin WI, Holmes EC, Garry RF. The proximal origin of SARS-CoV-2. Nat Med. 2020 Apr;26(4):450-2.

143. Calisher C, Carroll D, Colwell R, Corley RB Daszak P, Drosten C, et al. Statement in support of the scientists, public health professionals, and medical professionals of China combatting COVID-19. Lancet. 2020 Ma 7;395(10226):e42-e3.

144. Biscayart C, Angeleri P, Lloveras S, Chaves TDSS, Schlagenhauf P, Rodríguez-Morales AJ. The next big threat to global health? 2019 nove coronavirus (2019-nCoV): what advice can we give to travellers?-Interim recommendations January 2020, from the Latin-American Society for Travel Medicine (SLAMVI). Travel Med Infect Dis. 2020;33:101567.

145. Rodríguez-Morales AJ, Bonilla-Aldana DK, BalbinRamon GJ, Rabaan AA, Sah R, Paniz-Mondolfi A et al. History is repeating itself: Probable zoonotic spillover as the cause of the 2019 novel Coronavirus epidemic. Infez Med. 2020 Mar 1;28(1):3-5

146. Ahmad T, Khan M, Haroon, Musa TH, Nasir S, Hui J, et al. COVID-19: zoonotic aspects. Travel Med Infect Dis. 2020 Feb 27:101607.

147. Li HY, Zhu GJ, Zhang YZ, Zhang LB, Hagan EA Martinez $S$, et al. A qualitative study of zoonotic risk factors among rural communities in southern China. Int Health. 2020 Feb 12;12(2):77-85.

148. Almendros A. Can companion animals become infected with Covid-19? Vet Rec. 2020 Mar 28;186(12):388-9.
149. Parry NMA. COVID-19 and pets: when pandemic meets panic. Forensic Sci Int: Reports. 2020 Dec;2:100090.

150. Sit THC, Brackman CJ, Ip SM, Tam KWS, LawPYT, To EMW, et al. Infection of dogs with SARS-CoV-2 [Internet]. London: Springer Nature; 2020 May 14 [cited 2020 Jun 16]; [about 6 p.]. Available at: https://www.nature.com/articles/s41586-020-23 34-5

151. Li X. Can cats become infected with Covid-19? Vet Rec. 2020 Apr 18;186(14):457-8

152. Newman A, Smith D, Ghai RR, Wallace RM, Torchetti MK, Loiacono C, et al. First reported cases of SARS-CoV-2 infection in companion animals - New York, MarchApril 2020. MMWR Morb Mortal Wkly Rep. 2020 Jun 12:69(23):710-3.

153. Oreshkova N, Molenaar R-J, Vreman S, Harders F, Munnink BBO, Hakze R, et al. SARS-CoV2 infection in farmed mink, Netherlands, April 2020. bioRxiv [Internet]. New York: Cold Spring Harbor Lab; 2020 May 18 [cited 2020 May 27]. Available at: https://www.biorxiv.org/content/10.1101/2020 05.18.101493v1

154. Centers for Disease Control and Prevention (CDC) [Internet]. Atlanta: Centers for Disease Control and Prevention (CDC); Coronavirus disease (COVID-19). Your Health. COVID-19 and Animals; [updated 2020 Aug 24; cited 2020 Apr 28]. Available at: https://www.cdc.gov/coronavirus/2019 -ncov/daily-life-coping/animals.html

155. Shanthikumar SR. We should err on side of caution with Covid-19 advice. Vet Rec. 2020 Apr 18;186(14):458. DOI: 10.1136/vr.m1488.

156. Lu J, Gu J, Li K, Xu C, Su W, Lai Z, et al. Early release-COVID-19 outbreak associated with air conditioning in restaurant, Guangzhou, China, 2020. Emerg Infect Dis. 2020 Jul;26:1320-3.

157. Dietz L, Horve PF, Coil DA, Fretz M, Eisen JA, Van Den Wymelenberg K. 2019 novel Coronavirus (COVID-19) pandemic: built environment considerations to reduce transmission. mSystems. 2020 Apr 7;5(2).pii: e00245-20. DOI: 10.1128/mSystems.00245-20.

158. Centers for Disease Control and Prevention (CDC) [Internet]. Atlanta: Center for Disease Control and Prevention (CDC); c2020. Coronavirus Disease 2019 (COVID-19). Health Departments. COVID-19 and Cooling Centers; [updated 2020 Apr 11; cited 2020 Apr 28]. Available at: https://www.cdc.gov/coronavirus/2019 -ncov/php/cooling-center.html

159. Zhang J, Tian S, Lou J, Chen Y. Familial cluster of COVID-19 infection from an asymptomatic. Crit Care. 2020 Mar 27;24(1):119. DOI: 10.1186/ s13054-020-2817-7.

160. Jing QL, Liu MJ, Yuan J, Zhang ZB, Zhang AR, Dean NE, et al. Household secondary attack rate of COVID-19 and associated determinants. medRxiv [Internet]. New York: Cold Spring Harbor Lab; 2020 Apr 15 [cited 2020 Apr 25]. Available at: https://www.medrxiv.org/content/10.1101 /2020.04.11.20056010v1

161. Hu Z, Song C, Xu C, Jin G, Chen Y, Xu X, et al. Clinical characteristics of 24 asymptomatic infections with COVID-19 screened among close contacts in Nanjing, China. Sci China Life Sci. 2020 May;63(5):706-11.

162. Guan Q, Liu M, Zhuang YJ, Yuan Y, Wang SS, Li $\mathrm{J}$, et al. [Epidemiological investigation of a family clustering of COVID-19]. Zhonghua Liu Xing Bing Xue ZaZhi. 2020 May 10;41(5):629-33. Chinese.

163. Qiu YY, Wang SQ, Wang XL, Lu WX, Qiao D, Li $\mathrm{JB}$, et al. [Epidemiological analysis on a family cluster of COVID-19]. Zhonghua Liu Xing Bing Xue Za Zhi. 2020 Apr 10;41(4):506-9. Chinese.

164. Pan X, Chen D, Xia Y, Wu X, Li T, Ou X, et al. Asymptomatic cases in a family cluster with SARS-CoV-2 infection. Lancet Infect Dis. 2020 Apr;20(4):410-1. 
165. Chan JF, Yuan S, Kok KH, To KK, Chu H, Yang $\mathrm{J}$, et al. A familial cluster of pneumonia associated with the 2019 novel coronavirus indicating person-to-person transmission: a study of a family cluster. Lancet. 2020 Feb 15;395(10223):514-23.

166. Yu P, Zhu J, Zhang Z, Han Y. A familial cluster of infection associated with the 2019 novel coronavirus indicating potential person-to-person transmission during the incubation period. J Infect Dis. 2020 May 11;221(11):1757-61.

167. Huang R, Xia J, Chen Y, Shan C, Wu C. A family cluster of SARS-CoV-2 infection involving 11 patients in Nanjing, China. Lancet Infect Dis. 2020 May:20(5):534-5

168. Zou L, Ruan F, Huang M, Liang L, Huang H, Hong $Z$, et al. SARS-CoV-2 viral loading upper respiratory specimens of infected patients. N Engl J Med. 2020 Mar 19;382(12):1177-9.

169. Rothe C, Schunk M, Sothmann P, Bretzel G, Froeschl G, Wallrauch C, et al. Transmission of 2019-nCoV infection from an asymptomatic contact in Germany. N Engl J Med. 2020 Mar 5;382(10):970-1.

170. Heald-Sargent T, Muller WJ, Zheng X, Rippe J, Patel AB, Kociolek LK. Age-related differences in nasopharyngeal severe acute respiratory syndrome Coronavirus 2 (SARS-CoV-2) levels in patients with mild to moderate Coronavirus disease 2019 (COVID-19). JAMA Pediatr. 2020 Jul 30. DOI: 10.1001/jamapediatrics.2020.3651.

171. Park YJ, Choe YJ, Park O, Park SY, Kim YM, Kim J, et al. Contact tracing during Coronavirus disease outbreak, South Korea, 2020. Emerg Infect Dis. 2020 Jul16;26(10). DOI: 10.3201/ eid2610.201315.

172. Park SY, Kim YM, Yi S, Lee S, Na BJ, Kim CB et al. Coronavirus disease outbreaking call center, South Korea. Emerg Infect Dis. 2020 Aug;26(8):1666-70.

173. James A, Eagle L, Phillips C, Hedges DS, Bodenhamer C, Brown R, et al. High COVID-19 Attack Rate Among Attendees at Events at a Church - Arkansas, March 2020. MMWR Morb Mortal Wkly Rep. 2020 May 22;69(20):632-5.

174. Jang S, Han SH, Rhee JY. Cluster of Coronavirus disease associated with fitness dance classes, South Korea. Emerg Infect Dis. 2020 Aug;26(8):1917-20.

175. Hamner L, Dubbel P, Capron I, Ross A, Jordan A, Lee J, et al. High SARS-CoV-2 attack rate following exposure at a choir practice - Skagit County, Washington, March 2020. MMWR Morb Mortal Wkly Rep. 2020 May 15;69(19):606-10.

176. Naserghandi A, Allameh SF, Saffarpour R. All about COVID-19 in brief. New Microbes New Infect. 2020 Apr 13;35:100678. DOI: 10.1016/j. nmni.2020.100678.

177. Jalava K. First respiratory transmitted food borne outbreak? Int J Hyg Environ Health. 2020 May;226:113490.

178. World Health Organization. COVID-19 and food safety: guidance for food businesses [Internet]. Geneva: World Health Organization; 2020 Apr 7 [cited 2020 Apr 30] Available at: https://www.who.int/publications/i/ item/covid-19-and-food-safety-guidance-for -food-businesses

179. Centers for Disease Control and Prevention (CDC) [Internet]. Atlanta: Centers for Disease Control and Prevention (CDC); c2020. Food Safety Newsletters. Food safety and coronavirus disease 2019 (COVID-19); 2020 [cited 2020 Apr 28]. Available at: https://www.cdc.gov/foodsafe ty/newsletter/food-safety-and-Coronavirus.html

180. Centers for Disease Control and Prevention (CDC) [Internet]. Atlanta: Centers for Disease Control and Prevention (CDC); c2020. Frequently Asked Questions. Water; [cited 2020
Apr 30]. Available at: https://www.cdc.gov/ coronavirus/2019-ncov/php/water.html

181. Yu F, Yan L, Wang N, Yang S, Wang L, Tang Y, et al. Quantitative detection andviral load analysis of SARS-CoV-2 in infected patients. Clin Infect Dis. 2020 Jul28;71(15):793-8.

182. Wang XW, Li JS, Jin M, Zhen B, Kong QX, Song $N$, et al. Study on the resistance of severe acute respiratory syndrome-associated coronavirus. J Virol Methods. 2005 Jun;126(12):171-7.

183. Casanova L, Rutala WA, Weber DJ, Sobsey MD. Survival of surrogate coronaviruses in water. Water Res. 2009 Apr;43(7):1893-8.

184. Water Services Association of Australia - COVID-19. SARS-CoV-2 - Water and Sanitation Fact Sheet [Internet]. Adelaide: Water Research Australia; [updated 2020 Mar 5; cited 2020 Apr 30]. 3 p. Available at: https://www.waterra.com au/ r9550/media/system/attrib/file/2200/Water RA_FS_Coronavirus_V11.pdf

185. World Health Organization [Internet]. Geneva: World Health Organization; c2020. Publications. Overview. Water, sanitation, hygiene and waste management for SARS-CoV-2, the virus that causes COVID-19; 2020 Jul 29 [cited 2020 Aug 3]. 11 p. Available at: https://www.who.int/ publications-detail/water-sanitation-hygiene -and-waste-management-for-covid-19

186. La Rosa G, Bonadonna L, Lucentini L, Kenmoe $S$, Suffredini E. Coronavirus in water environments: occurrence, persistence and concentration methods - A scoping review. Water Res. 2020 Jul 15;179:115899. DOI: 10.1016/j. watres.2020.115899.

187. Centers for Disease Control and Prevention (CDC) [Internet]. Atlanta: Centers for Disease Control and pfrevention (CDC); c2020. Coronavirus Disease 2019 (COVID-19). Health Care Workers. Clinical Questions about COVID-19: Questionsand Answers. Waste management; [updated 2020 Aug 4; cited 2020 Apr 30]. Available at: https://www.cdc.gov/coronavirus/2019 -ncov/hcp/faq.html\#Waste-Management

188. Huang YS, Vanlandingham DL, Bilyeu AN, Sharp HM, Hettenbach SM, Higgs S. SARS-CoV-2 failure to infect or replicate in mosquitoes: an extreme challenge. Sci Rep. 2020 Jul 17;10(1):11915. DOI: 10.1038/s41598-020-68882-7.

189. World Health Organization [Internet]. Geneva: World Health Organization; c2020. Coronavirus disease (COVID-19). Advice for the public. Myth busters; [cited 2020 Apr 30]; [about 6 p.]. Available at: https://www.who.int/emergencies/diseases/novel -coronavirus-2019/advice-for-public/myth-busters

190. American Mosquito Control Association [Internet]. Sacramento, CA: American Mosquito Control Association; c2020. News and Press. Can mosquitoes transmit the coronavirus?; $2020 \mathrm{Mar}$ 10 [cited 2020 Apr 30]. Available at: https://www mosquito.org/news/492656/Can-Mosquitoes -Transmit-the-Coronavirus.htm

191. Franchini M, Farrugia A, Velati C, Zanetti A, Romanò L, Grazzini G, et al. The impact of the SARS-CoV-2 outbreak on the safety and availability of blood transfusions in Italy. Vox Sang. 2020 Apr 2. DOI: 10.1111/vox.12928.

192. Chang L, Yan Y, Wang L. Coronavirus disease 2019: coronaviruses and blood safety. Transfus Med Rev. 2020 Apr;34(2):75-80.

193. Dodd RY, Stramer SL. COVID-19 and blood safety: help with a dilemma. Transfus Med Rev. 2020 Apr;34(2):73-4.

194. Heneghan C, Brassey J, Jefferson T. SARSCoV-2 viral load and the severity of COVID-19 [Internet]. Oxford: Centre for Evidence-Based Medicine; 2020 Mar 26 [cited Apr 17]. Available at: https://wwwcebmnet/covid-19/sars-cov-2-vi ral-load-and-the-severity-of-covid-19/
195. Kwon SY, Kim EJ, Jung YS, Jang JS, Cho NS Post-donation COVID-19 identificationin blood donors. Vox Sanguini [Internet]. Amsterdam: International Society of Blood Transmission; 2020 Apr 2 [cited 2020 Apr 17]. Available at: https://onlinelibrary.wiley.com/doi/epdf/10.1111/ vox.12925

196. Cho HJ, Koo JW, Roh SK, Kim YK, Suh JS, Moon $\mathrm{JH}$, et al. COVID-19 transmission and blood transfusion: a case report. J Infect Public Health. 2020 May 13. DOI: 10.1016/j.jiph.2020.05.001.

197. Liu W, Li H. COVID-19: Attacks the 1-beta chain of hemoglobin and captures the porphyrin to inhibit human heme metabolism. chemRxiv [Internet]. New York: Cold Spring Harbor Lab; 2020 Jul 13 [cited 2020 Jul 25]. Available at: https://chemrxiv .org/articles/preprint/COVID19_Disease_ORF8 _and_Surface_Glycoprotein_Inhibit_Heme_Me tabolism by Binding to Porphyrin/11938173

198. Chang L, Zhao L, Gong H, Wang L, Wang L. Severe acute respiratory syndrome coronavirus 2 RNA detected in blood donations. Emerg Infect Dis. 2020 Jul;26(7):1631-3.

199. European Center for Disease Prevention and Control. Outbreak of acute respiratory syndrome associated with a novel Coronavirus, Wuhan, China; first update [Internet]. Stockholm: European Center for Disease Prevention and Control 2020 Jan 22 [cited 2020 May 1]. 12 p. Available at: https://www.ecdc.europa.eu/sites/default/ files/documents/Risk-assessment-pneumonia -Wuhan-China-22-Jan-2020.pdf

200. American Association of Blood Banks. Update: impact of 2019 novel coronavirus and blood safety [Internet]. Maryland: American Association of Blood Banks; 2020 [cited 2020 May 1]. 6 p. Available at: http://www.aabb.org/advocacy/ regulatorygovernment/Documents/Impact-of -2019-Novel-Coronavirus-on-Blood-Donation.pdf

201. The New York Blood Center Enterprises. COVID-19 and Blood Donation [Internet]. New York: New York Blood Center Enterprises; c2020 [cited 2020 May 1]. Available at: https://www.nybc .org/donate-blood/covid-19-and-blood-donation -copyl

202. Michaels MG, La Hoz RM, Danziger-Isakov L, Blumberg EA, Kumar D, Green M, et al. Coronavirus disease 2019: implications of emerging infections for transplantation. Am J Transplant. 2020 Jul;20(7):1768-72

203. Saigal S, Gupta S, Sudhindran S, Goyal N, Rastogi $A$, Jacob $M$, et al. Liver transplantation and COVID-19 (Coronavirus) infection: guidelines of the liver transplant Society of India (LTSI). Hepatol Int. 2020 Jul;14(4):429-31.

204. Bhoori S, Rossi RE, Citterio D, Mazzaferro V. COVID-19 in long-term liver transplant patients: preliminary experience from an Italian transplant centre in Lombardy. Lancet Gastroenterol Hepatol. 2020 Jun;5(6):532-3.

205. Banerjee D, Popoola J, Shah S, Ster IC, Quan V, Phanish M. COVID-19 infection in kidney transplant recipients. Kidney Int. 2020 Jun;97(6):1076-82.

206. Wang R, Liao C, He H, Hu C, Wei Z, Hong Z, et al COVID-19 in hemodialysis patients: a report of 5 cases. Am J Kidney Dis. 2020 Jul;76(1):141-3.

207. Ferrey AJ, Choi G, Hanna RM, Chang Y, Tantisattamo $\mathrm{E}$, Ivaturi $\mathrm{K}$, et al. A case of novel Coronavirus disease 19 in a chronic hemodialysis patient presenting with gastroenteritis and developing severe pulmonary disease. Am J Nephrol. 2020;51(5):337-42.

208. American Society of Nephrology. Information for screening and management of COVID-19 in the outpatient dialysis facility [Internet]. Washington, D.C.: American Society of Nephrology; 2020 Ma 13 [cited 2020 Apr 30]. 7 p. Available at: https:// www.asn-online.org/g/blast/files/DIALYSIS CO VID_2019_Update_03.13.2020_FINAL.pdf 
209. Centers for Disease Control and Prevention (CDC). Atlanta: Centers or Disease Control and Prevention (CDC); c2020. Coronavirus Disease (COVID-19). Healthcare Workers. Considerations for providing hemodialysis to patients with suspected or confirmed COVID-19 in acute care settings; [updated $2020 \mathrm{Jul}$ 7; cited 2020 Apr 30]. Available at: https://www.cdc.gov/ coronavirus/2019-ncov/hcp/dialysis/dialysis-in -acute-care.html

210. Ikizler TA, Kliger AS. Minimizing the risk of COVID-19 among patients on dialysis. Nat Rev Nephrol. 2020 Jun;16(6):311-3.

211. Weiner DE, Watnick SG. Hemodialysis and COVID-19: an Achilles' heeling the pandemic health care response in the United States. Kidney Med. 2020 May-Jun;2(3):227-30.

212. Kliger AS, Silberzweig J. Mitigating risk of COVID-19 in dialysis facilities. Clin J Am Soc Nephrol. 2020 May 7;15(5):707-9.

213. Wang D, Hu B, Hu C, Zhu F, Liu X, Zhang J, et al. Clinical characteristics of 138 hospitalized patients with 2019 novel coronavirus-infected pneumonia in Wuhan,China. JAMA. 2020 Feb 7. DOI: 10.1001/jama.2020.1585

214. Jiang WY, Xiong R, Lu ZL. Clinical practice of prevention and treatment of novel Coronavirus infection in the medical personnel and surgical patients in the Department of Thoracic Surgery of Hospitals in Wuhan. Chin J Thoracic Cardiovasc Surg. 2020;27:364-70.

215. Cao G, Tang S, Yang D, Shi W, Wang X, Wang $\mathrm{H}$, et al. One nosocomial cluster following with a familial cluster of COVID-19 cases: the potential transmission risk inpatients with negative swab tests [Internet]. North Carolina: Res Square; 2020 May 29 [cited 2020 Jul 20].15 p. Available at: https://www.researchsquare.com/article/rs $-17879 / v 1$

216. Wang Q, Kuang W, Ping W. Prevention and treatment of cross infection of novel Coronavirus pneumonia in thoracic surgery ward. Chin J Thoracic Cardiovasc Surg. 2020;27:371-5.

217. Zhou Q, Gao Y, Wang X, Liu R, Du P, Wang X, et al. Nosocomial infections among patients with COVID-19, SARS and MERS: a rapid review and meta-analysis. medRxiv[Internet]. New York: Cold Spring Harbor Lab; 2020 Apr 17 [cited 2020 Apr 25]. Available at: https://www.medrxiv.org/ content/10.1101/2020.04.14.20065730v1

218. Wee LE, Conceicao EP, Sim XYJ, Aung MK, Tan $\mathrm{KY}$, et al. Minimising intra-hospital transmission of COVID-19: the role of social distancing. J Hosp Infect. 2020 Jun;105(2):113-5.

219. Wong SCY, Kwong RTS, Wu TC, Chan JWM, Chu MY, Lee SY, et al. Risk of nosocomial transmission of coronavirus disease 2019: an experience in a general ward setting in Hong Kong. J Hosp Infect. 2020 Jun;105(2):119-27.

220. Wang L, Chen X, Ye L. Integrated infection control strategy to minimize nosocomial infection during outbreak of COVID-19 among ED healthcare workers. J Emerg Nursing. 2020 Jul:46(4):424-5.

221. Klompas M. Coronavirus disease 2019 (COVID-19): protecting hospitals from the invisible. Ann Intern Med. 2020 May 5;172(9):619-20.

222. Simonds A, Hanak A, Chatwin M, Morrell M, Hall $\mathrm{A}$, Parker $\mathrm{KH}$, et al. Evaluation of droplet dispersion during non-invasive ventilation, oxygen therapy, nebuliser treatment and chest physiotherapy in clinical practice: implications for management of pandemic influenza and other airborne infections. Health Technol Assess. 2010 Oct;14(46):131-72.

223. Hui D, Chan M, Chow B. Aerosol dispersion during various respiratory therapies: a risk assessment model of nosocomial infection to health care workers. Hong Kong Med J. 2014 Aug;20 Suppl 4:9-13.
224. Cabrini L, Landoni G, Zangrillo A. Minimise nosocomial spread of 2019-nCoV when treating acute respiratory failure. Lancet. $2020 \mathrm{Feb}$ 29;395(10225):685. DOI: 10.1016/S01406736(20)30359-7.

225. Chen X, Tian J, Li G, Li G. Initiation of a new infection control system for the COVID-19 outbreak. Lancet Infect Dis. 2020 Apr;20(4):397-8.

226. Peng J, Ren N, Wang M, Zhang G. Practical experiences and suggestions for the 'eagle-eyed observer': a novel promising role for controlling nosocomial infection in the COVID-19 outbreak. J Hosp Infect. 2020 May;105(1):106-7.

227. Varia M, Wilson S, Sarwal S, McGeer A, Gournis E, Galanis E. Investigation of a nosocomia outbreak of severe acute respiratory syndrome (SARS) in Toronto, Canada. CMAJ. 2003 Aug 19;169(4):285-92.

228. Lee $N$, Hui $D$, Wu $A$, Chan $P$, Cameron $P$, Joynt $\mathrm{GM}$, et al. A major outbreak ofsevere acute respiratory syndrome in Hong Kong. $\mathrm{N}$ Engl J Med. 2003 May 15;348(20):1986-94.

229. Hunter E, Price DA, Murphy E, van der Loeff IS, Baker KF, Lendrem D, et al. First experience of COVID-19 screening of health-care workers in England. Lancet. 2020 May 2;395(10234):e77-e8.

230. Liu M, He P, Liu HG, Wang XJ, Li FJ, Chen $\mathrm{S}$, et al. [Clinical characteristics of 30 medical workers infected with new coronavirus pneumonia]. Zhonghua Jie $\mathrm{He} \mathrm{He} \mathrm{HuXi} \mathrm{Za}$ Zhi. 2020 Feb 17;43:E016. DOI: 10.3760/ cma.j.issn.1001-0939.2020.0016. Chinese.

231. Zhan M, Qin $Y$, Xue X, Zhu S. Death from Covid-19 of 23 health care workers in China. N Engl J Med. 2020 Jun 4;382(23):2267-8.

232. Ran L, Chen X, Wang Y, Wu W, Zhang L, Tan X. Risk factors of healthcare workers with corona virus disease 2019: a retrospective cohort study in a designated hospital of Wuhan in China. Clin Infect Dis. 2020 Mar 17. pii: ciaa287. DOI: 10.1093/cid/ciaa287.

233. Ng K, Poon BH, Kiat Puar TH, Shan Quah JL, Loh WJ, Wong YJ, et al. COVID-19 and the risk to health care workers: a case report. Ann Intern Med. 2020 Jun 2:172(11):766-7.

234. COVID-19: protecting health-care workers. Lancet. 2020 Mar 21;395(10228):922

235. World Health Organization [Internet]. Copenhagen: World Health Organization Regional Office for Europe; c2020. Newsroom. Detail. Shortage of personal protective equipment endangering health workers worldwide; 2020 Mar 3 [cited 2020 Apr 27]. Available at: https://www.who.int/ news-room/detail/03-03-2020-shortage-of-per sonal-protective-equipment-endangering-health -workers-worldwide

236. Cheng VC, Wong SC, Yuen KY. Estimating Coronavirus disease 2019 infection risk in health care workers. JAMA Netw Open. 2020 May 1;3(5):e209687. DOI: 10.1001/jamanetworkopen.2020.9687.

237. Kluytmans-van den Bergh MFQ, Buiting AGM, Pas SD, Bentvelsen RG, van denBijllaardt W, van Oudheusden AJG, et al. Prevalence and clinical presentation of health care workers with symptoms of Coronavirus disease 2019 in 2 Dutchhospitals during an early phase of the pandemic. JAMA Netw Open. 2020 May 1;3(5):e209673. DOI: 10.1001/jamanetworkopen.2020.9673.

238. Iken $\mathrm{O}$, Abakporo $\mathrm{U}$, Ayobami O, Attoye $\mathrm{T}$. COVID-19: Travel health and the implications for sub -Saharan Africa. Travel Med Infect Dis 2020 May-Jun;35:101645. DOI: 10.1016/j. tmaid.2020.101645

239. World Health Organization [Internet]. Geneva: World Health Organization; c2020. Publication. Overview. Interim guidance: management of ill travellers atpoints of entry-international airports, ports and ground crossings-in the context ofthe COVID-19 outbreak; 2020 Mar 19 [cited 2020 Apr 27]. Available at: https://www.who .int/publications/i/item/10665-331512

240. World Health Organization [Internet]. Geneva: World Health Organization; c2020. Newsroom. Article. Updated WHO recommendations for international traffic in relation to COVID-19 outbreak; 2020 Feb 29 [cited 2020 Apr 27]. Available at: https://www.who.int/news-room/articles-detail/ updated-who-recommendations-for-internation al-traffic-in-relation-to-covid-19-outbreak

241. Zhong P, Guo S, Chen T. Correlation between travellers departing from Wuhan before the Spring Festival and subsequent spread of COVID-19 to all provinces in China. J Travel Med. 2020 May 18;27(3). pii: taaa036. DOI: 10.1093/ jtm/taaa036

242. Zhao S, Zhuang Z, Cao P, Ran J, Gao D, Lou $Y$, et al. Quantifying the association between domestic travel and the exportation of novel coronavirus (2019-nCoV) cases from Wuhan, China in 2020: a correlational analysis. J Travel Med. 2020 Mar 13;27(2). pii: taaa022. DOI: 10.1093/jtm/taaa022.

243. Devi S. Travel restrictions hampering COVID-19 response. Lancet. 2020 Apr 25;395(10233):1331-2.

244. Ng O-T, Marimuthu K, Chia PY, Koh V, Chiew CJ, De Wang $L$, et al. SARS-CoV-2 infection among travelers returning from Wuhan, China. N Engl J Med. 2020 Apr 9;382(15):1476-8.

245. Kuan MM, Lin T, Chuang JH, Wu HS. Epidemiological trends and the effect of airport fever screening on prevention of domestic dengue fever outbreaks in Taiwan,1998-2007. Int J Infect Dis. 2010 Aug;14(8):e693-e7

246. Thwaites GE, Day NP. Approach to fever in the returning traveler. N Engl J Med. 2017 Feb 9;376(6):548-60.

247. Backer JA, Klinkenberg D, Wallinga J. Incubation period of 2019 novel coronavirus (2019nCoV) infections among travellers from Wuhan, China, 20-28 January 2020. Euro Surveill. 2020 Feb;25(5). DOI: 10.2807/1560-7917. ES.2020.25.5.2000062

248. Okada $P$, Buathong $R$, Phuygun $S$, Thanadachakul T, Parnmen S, Wongboot W, et al. Early transmission patterns of coronavirus disease 2019 (COVID-19) in travellers from Wuhan to Thailand, January 2020. Euro Surveill. 2020 Feb;25(8). DOI: 10.2807/1560-7917. ES.2020.25.8.2000097.

249. Hoehl S, Rabenau H, Berger A, Kortenbusch $M$, Cinatl J, Bojkova D, et al. Evidence of SARS-CoV-2 Infection in Returning Travelers from Wuhan, China. N Engl J Med. 2020 Mar 26;382(13):1278-80.

250. Samaan G, Patel M, Spencer J, Roberts L. Border screening for SARS in Australia: what has been learnt? Med J Aust. 2004 Mar 1;180(5):220-3.

251. Quilty BJ, Clifford S, Flasche S, Eggo RM; CMMID nCoV working group. Effectiveness of airport screening at detecting travellers infected with novel coronavirus (2019-nCoV). Euro Surveill. 2020 Feb;25(5). DOI: 10.2807/1560-7917. ES.2020.25.5.2000080

252. Bwire GM, Paulo LS. Coronavirus disease-2019: is fever an adequate screening for the returning travelers? Trop Med Health. 2020 Mar 9;48:14.

253. Anzai A, Kobayashi T, Linton NM, Kinoshita R, Hayashi K, Suzuki A, et al. Assessing the impact of reduced travel on exportation dynamics of novel coronavirus infection (COVID-19). J Clin Med. 2020 Feb 24;9(2). pii: E601.DOI: 10.3390/ jcm9020601.

254. Chinazzi M, Davis JT, Ajelli M, Gioannini C, Litvinova M, Merler S, et al. The effect of trave restrictions on the spread of the 2019 novel coronavirus (COVID-19) outbreak. Science. 2020 Apr 24;368(6489):395-400. 
255. Karami M, Doosti-Irani A, Ardalan A, GohariEnsaf $F$, Berangi $Z$, Massad $E$, et al. Public health threats in mass gatherings: asystematic review. Disaster Med Public Health Prep. 2019 Dec;13(5-6):1035-46.

256. Memish ZA, Steffen R, White P, Dar O, Azhar El, Sharma A, et al. Mass gatherings medicine: public health issues arising from mass gathering religious and sporting events. Lancet. 2019 May 18;393(10185):2073-84.

257. Ebrahim SH, Memish ZA. COVID-19 - the role of mass gatherings. Travel Med Infect Dis. 2020 Mar-Apr;34:101617. DOI: 10.1016/j. tmaid.2020.101617.

258. McCloskey B, Zumla A, Ippolito G, Blumberg L, Arbon $\mathrm{P}$, Cicero A, et al. Mass gathering events and reducing further global spread of COVID-19: a political and public health dilemma. Lancet. 2020 Apr 4;395(10230):1096-9.

259. Petersen E, Memish ZA, Zumla A, Maani AA. Transmission of respiratory tract infections at mass gathering events. Curr Opin Pulm Med. 2020 May;26(3):197-202.

260. Lai CC, Shih TP, Ko WC, Tang HJ, Hsueh PR. Severe acute respiratory syndrome coronavirus 2 (SARS-CoV-2) and coronavirus disease-2019 (COVID-19): the epidemic and the challenges. Int J Antimicrob Agents. 2020 Mar;55(3). DOI:10.1016/j.ijantimicag.2020.105924

261. Nunan D, Brassey J. What is the evidence for mass gatherings during global pandemics? A rapid summary of best-available evidence [Internet]. Oxford: Center for Evidene-Based Medicine (CEBM); 2020 Mar 20 [cited 2020 May 4]. Available at: https://www.cebm.net/covid-19/ what-is-the-evidence-for-mass-gatherings-during-global-pandemics/

262. Centers for Disease Control and Prevention (CDC) [Internet]. Atlanta: Centers for Disease Control and Prevention (CDC); c2020. Coronavirus disease (COVID-19). Community, Work and Schools. Gatherings and Community Events: plan, prepare and respond; 2020 Jun 12 [cited 2020 Apr 28]. Available at: https://www.cdc. gov/coronavirus/2019-ncov/community/largeevents/index.html

263. World Health Organization. Interim guidance: Key planning recommendations form as gatherings in the context of the current COVID-19 outbreak [Internet]. Geneva: World Health Organization; 2020 [cited 2020 Apr 30]. Available at: https://apps.who.int/ iris/bitstream/handle/10665/331004/WHO2019-nCoV-POEmassgathering-2020.1 -eng.pdf?sequence $=1$ \&isAllowed $=y$

264. Centers for Disease Control and Prevention (CDC) [Internet]. Atlanta:Centers for Disease Control and Prevention (CDC); c2020. Coronavirus disease (COVID-19). Get Your Mass Gatherings or Large Community Events Ready; 2020 [cited 2020 Apr 28]. Available at: https:// www.cdc.gov/coronavirus/2019-ncov/commu nity/large-events/mass-gatherings-ready-for -covid-19.htm

265. World Health Organization [Internet]. Geneva: World Health Organization; c2020.Q\&A on Mass Gatherings and COVID-19; 2020 [cited 2020 Apr 30]. Available at: https://www.who.int/news-room/qa-detail/q-a-on-mass-gatherings-and-covid-19

266. Rodríguez-Morales AJ, Gallego V, EscaleraAntezana JP, Mendez CA, Zambrano LI, FrancoParedes C, et al. COVID-19 in Latin America: the implications of the first confirmed case in Brazil. Travel Med Infect Dis. 2020 May-Jun;35:101613. DOI: 10.1016/j.tmaid.2020.101613

267. Kluge HHP, Jakab Z, Bartovic J, D'Anna V, Severoni S. Refugee and migrant health in the COVID-19 response. Lancet. $2020 \mathrm{Apr}$ 18;395(10232):1237-9.
268. COVID-19 will not leave behind refugees and migrants. Lancet. 2020 Apr 4;395(10230):1090.

269. World Health Organization Regional Office for Europe [Internet]. Geneva: World Health Organization; c2020. Health Topics. COVID-19: ensuring refugees and migrants are not left behind 2020 Apr 16 [cited 2020 Apr 27]. Available at: http://www.euro.who.int/en/health-topics/ health-determinants/migration-and-health/news/ news/2020/4/covid-19-ensuring-refugees-and -migrants-are-not-left-behind

270. World Health Organization Regional Office for Europe [Internet]. Interim guidance for refugee and migrant health in relation to COVID-19 in the WHO European Region Geneva: World Health Organization; 2020 Mar 25 [cited 2020 Apr 27]. Available at: http://www.euro .who.int/en/health-topics/health-determinants/ migration-and-health/publications/2020/ interim-guidance-for-refugee-and-migrant -health-in-relation-to-covid-19-in-the-who-euro pean-region-2020

271. Tsai J, Wilson M. COVID-19: a potential public health problem for homeless populations. Lancet Public Health. 2020 Apr;5(4):e186-e7.

272. Baggett TP, Hwang SW, O'Connell JJ, Porneala $B C$, Stringfellow EJ, Orav EJ, et al. Mortality among homeless adults in Boston: shifts in causes of death over a 15-year period. JAMA Intern Med. 2013 Feb 11;173(3):189-95.

273. Lima NNR, de Souza RI, Feitosa PWG Moreira JLS, da Silva CGL, Neto MLR. People experiencing homelessness: their potential exposure to COVID-19. Psychiatry Res. 2020 Apr 11;288:112945. DOI: 10.1016/j.psychres.2020.112945

274. Leung CS, Ho MM, Kiss A, Gundlapalli AV, Hwang SW. Homelessness and the response to emerging infectious disease outbreaks: lessons from SARS. J Urban Health. 2008 May;85(3):402-10.

275. Centers for Disease Control and Prevention (CDC) [Internet]. Atlanta: Centers for Disease Control and Prevention (CDC); c2020. Coronavirus Disease 2019 (COVID-19). Community, Work and School. Interim Guidance for Homeless Service Providers to Plan and Respond to Coronavirus Disease 2019 (COVID-19); 2020 Aug 5 [cited 2020 Apr 28]. Available at: https://www.cdc.gov/ coronavirus/2019-ncov/community/homeless -shelters/plan-prepare-respond.htm

276. National Institute of Drug Abuse [Internet]. Maryland: National Institute of Drug Abuse; c2020. Nora's blog. COVID-19: Potential implications for individuals with substance use disorders; 2020 Apr 6 [cited 2020 Apr 28]; [about 8 p.]. Available at: https://www.drugabuse.gov/about-nida/noras -blog/2020/04/covid-19-potential-implications -individuals-substance-use-disorders

277. Farhoudian A, Baldacchino A, Clark N, Gerra G, Ekhtiari H, Dom G, et al. COVID-19 and substance use disorders: recommendations to a comprehensive healthcare response. An International Society of Addiction Medicine (ISAM) Practice and Policy Interest Group Position Paper. Basic Clin Neurosci. 2020 MarApr;11(2):133-46.

278. Volkow ND. Collision of the COVID-19 and addiction epidemics. Ann Inter Med. 2020 Jul 7;173(1):61-2.

279. Cai H. Sex difference and smoking predisposition in patients with COVID-19. Lancet Respir Med. 2020 Apr;8(4):e20. DOI: 10.1016/ S2213-2600(20)30117-X

280. Cai G. Bulk and single-cell transcriptomics identify tobacco-use disparity in lung gene expression of ACE2, the receptor of 2019-nCov. medRxiv [Internet]. New York: Cold Spring Harbor Lab; 2020 Feb 28 [cited 2020 Apr 25]. Avail- able at: https://www.medrxiv.org/content/10.110 1/2020.02.05.20020107v3

281. Leung JM, Yang CX, Tam A, Shaipanich T, Hackett TL, Singhera GK, et al. ACE-2 expression in the small airway epithelia of smokers and COPD patients: implications for COVID-19. Eur Respir J. 2020 May 14;55(5). pii: 2000688. DOI 10.1183/13993003.00688-2020.

282. Vardavas $\mathrm{Cl}$, Nikitara K. COVID-19 and smoking: a systematic review of the evidence. Tob Induc Dis. 2020 Mar 20;18:20. DOI: 10.18332/tid/119324.

283. Zhao Q, Meng M, Kumar R, Wu Y, Huang J, Lian N, et al. The impact of COPD and smoking history on the severity of Covid-19: a systemic review and meta-analysis. J Med Virol. $2020 \mathrm{Apr}$ 15. DOI: 10.1002/jmv.25889.

284. Rossato M, Russo L, Mazzocut S, Di Vincenzo A, Fioretto P, Vettor R. Current smok ing is not associated with COVID-19. Eur Respir J. 2020 Jun 4;55(6). pii:2001290. DOI: 10.1183/13993003.01290-2020.

285. Farsalinos K, Barbouni A, Niaura R. Smoking, vaping and hospitalization for COVID-19 [Internet]. London: Qeios; 2020 Apr 4 [cited 2020 May 25]. Available at: https://www.qeios .com/read/Z69O8A.13

286. Guan WJ, Liang WH, Zhao Y, Liang HR, Chen ZS, Li YM, et al. Comorbidity and its impact on 1590 patients with Covid-19 in China: a nationwide analysis. Eur Respir J. Eur Respir J. 2020 May 14;55(5). pii: 2000547. DOI 10.1183/13993003.00547-2020.

287. Emami A, Javanmardi $F$, Pirbonyeh N, Akbar A. Prevalence of underlying diseases in hospitalized patients with COVID-19: a systematic review and meta-analysis. Arch Acad Emerg Med. 2020 Mar 24;8(1):e35. PMID: 32232218.

288. Miyara M, Tubach F, Pourcher V, Morelot-Panzini C, Pernet J, Haroche J, et al. Low incidence of daily active tobacco smoking in patients with symptomatic COVID-19 [Internet]. London: Qeios; 2020 Apr 21 [cited 2020 May 25]. Available at: https://www.qeios.com/read/WPP19W.3

289. Changeux JP, Amoura Z, Rey F, Miyara M. A nicotinic hypothesis for Covid-19 with preventive nd therapeutic implications [Internet]. London: Qeios; 2020 Apr 21 [cited 2020 May 20]. Available at: https://www.qeios.com/read/FXGQSB

290. World Health Organization [Internet]. Geneva: World Health Organization; c2020. Q\&A on smoking and COVID-19; 2020 May 27 [cited 2020 Apr 27]. Available at: https://www.who.int/news -room/q-a-detail/q-a-on-smoking-and-covid-19

291. Wu Z, McGoogan JM. Characteristics of and important lessons from the Coronavirus disease 2019 (COVID-19) outbreak in China: summary of a report of 72314 cases from the Chinese center for disease control and prevention. JAMA 2020 Feb 24. DOI: 10.1001/jama.2020.2648.

292. World Health Organization [Internet]. Geneva: World Health Organization; c2020. Tobacco Free Initiative. Know the Truth. Tobacco and waterpipe use increases the risk of suffering from COVID-19; 2020 [cited 2020 Apr 27]. Available at: http://www.emro.who.int/tfi/know-the-truth/ tobacco-and-waterpipe-users-are-at-increased -risk-of-covid-19-infection.html

293. Madison MC, Landers CT, Gu BH, Chang CY, Tung HY, You R, et al. Electronic cigarettes disrupt lung lipid homeostasis and innate immunity independent of nicotine. J Clin Invest. 2019 Oct 1;129(10):4290-304

294. Simooya OO. Infections in prison in low and middle income countries: prevalence and prevention strategies. Open Infect Dis J. 2010;4:33-7.

295. Fazel S, Baillargeon J. The health of prisoners. Lancet. 2011 Mar12;377(9769):956-65.

296. Kinner SA, Young JT, Snow K, Southalan L, López-Acuña D, Ferreira-Borges C, et al. Pris- 
ons and custodial settings are part of a comprehensive response to COVID-19. Lancet Public Health. 2020 Apr;5(4):e188-e9.

297. Hawks L, Woolhandler S, McCormick D. COVID-19 in prisons and jails in the United States. JAMA Intern Med. 2020 Apr 28. DOI: 10.1001/ jamainternmed.2020.1856.

298. Walmsley R. World Prison Population List. 12th ed [Internet]. London: Institute for Criminal Policy Research, University of London; 2018 Sep [cited 2020 May 4].19 p. Available at: https://www.prison studies.org/sites/default/files/resources/down loads/wppl_12.pdf

299. Yang H, Thompson JR. Fighting covid-19 outbreaks in prisons. BMJ. 2020;369:m1362.

300. Centers for Disease Control and Prevention (CDC) [Internet]. Atlanta: Centers for Disease Control and Prevention (CDC); c2020. Coronavirus disease (COVID-19). Your Health.People who are at higher risk for severe illness; [updated 2020 Jun 25; cited 2020 Apr 28]. Available at: https://www.cdc.gov/coronavirus/2019-ncov/ need-extra-precautions/people-at-higher-risk .html

301. World Health Organization. Preparedness, prevention and control of COVID-19 inprisons and places of detention [Internet]. Copenhagen: World Health Organization Regional Office for Europe; 2020 Mar 15 [cited 2020 Apr 27]. 31 p. Available at: http://www.euro.who.int/_data/assets/pdf_file /0019/434026/Preparedness-prevention-and-con trol-of-COVID-19-in-prisons.pdf

\section{THE AUTHORS}

Ekram W. Abd El-Wahab (Corresponding author: ekram.wassim@alexu.edu.eg), assistant professor of tropical health with a master's degree in public health and a doctorate in molecular and cellular biology. Tropical Health Department, Division of Tropical Health, High Institute of Public Health, Alexandria University, Alexandria, Egypt. https://orcid.org/0000-0003 $-4220-5859$

Safaa M. Eassa, professor of parasitology and medical entomology with a master's and doctorate degrees in public health (parasitology and medical entomology). Tropical Health Department, Division of Parasitology and Medical Entomology, High Institute of Public Health, Alexandria University, Alexandria, Egypt. https:// orcid.org/0000-0001-9185-9141

Mohammed Metwally, consultant physician specializing in internal medicine, infectious and endemic diseases with a master's and doctorate degrees in internal medicine. Department of Endemic and Infectious Diseases, Alexandria Fever Hospital, Ministry of Health and Population, Alexandria, Egypt. https://orcid.org/0000 -0002-3341-7879
Husam Al-Hraishawi, lecturer, with a master's degree in veterinary medicine and physiology. Department of Physiology, College of Medicine, Misan University, Amarah-Maysan, Iraq. Researcher, Department of Medicine, Rutgers Cancer Institute of New Jersey, Rutgers University, USA. https://orcid.org/0000-0003-4169-1824

Sherif R. Omar, assistant professor of tropical health with master's and doctoral degrees in public health (tropical health), and a diploma in tropical medicine and hygiene. Tropical Health Department (Division of Tropical Health), High Institute of Public Health, Alexandria University, Alexandria, Egypt. https://orcid.org/0000-0002 $-9808-8412$

\section{DATA AVAILABILITY}

All data are fully available without restriction by the corresponding author at ekram.wassim@ alexu.edu.eg

Submitted: June 26, 2020

Approved for Publication: September 9, 2020 Disclosures: None 


\title{
Cuban Contributions to Latin American Clinical Care and Research on Diabetes and Pregnancy
}

\author{
Jeddú Cruz-Hernández MD MS, Antonio Márquez-Guillén MD PhD, Jacinto Lang-Prieto† MD, Ileydis Iglesias-Marichal MD MS
}

\begin{abstract}
Cuban participation in and contributions to education, medical care and research on diabetes and pregnancy in Latin America dates back to the 1970s when the Latin American Diabetes Association was founded. The Cuban health system and its professionals recognized early the problems presented by diabetes during pregnancy for the health of an expectant mother and her children and assimilated and disseminated important lessons that became influential in the region. These included: importance of adopting a program within primary health care that offers national coverage for diabetic pregnant women, with a special focus on pre-conception monitoring of diabetic women; benefits of defining a specific range for application of a fasting glucose test to identify risk of gestational diabetes through selective screening for the disease; using insulin to treat gestational diabetes; controlling excessive weight at the beginning and during pregnancy; and underscoring the importance of interdisciplinary treatment of diabetes in pregnancy. The goal was to improve care and research in reproductive health for diabetic pregnant women and their children in Cuba.
\end{abstract}

KEYWORDS: Gestational diabetes, pregnancy, Latin America, Cuba

\section{INTRODUCTION}

Systematic activities in specialized medical care and research on diabetes in pregnancy were formalized in Latin America with the creation of the Latin American Diabetes Association (ALAD), founded in 1970 in Buenos Aires, Argentina. ALAD's mission is to improve the quality of medical care, education and research regarding diabetes mellitus (DM) in the region, including diabetes during pregnancy.[1,2]

When ALAD was founded, morbidity and mortality from diabetes in Latin America was increasing, its steady growth leading to a significant public health problem for the region. Disease prevalence in different countries was reported at 1.2\%-7.3\%, and PAHO's Inter-American Investigation of Mortality estimated regional mortality at $2.6 \%$ with several countries showing an upward trend.

\section{IMPORTANCE}

Cuban professionals have made important theoretical and methodological contributions to the topic of diabetes in pregnancy in Latin America, leading to improved medical care for diabetic pregnant women. This article reviews these contributions and highlights their significance.
Diabetes prevalence in Cuba was $3.8 \%$ in 1970 and the mortality rate rose from 2.4 to 10.5 per 100,000 population from 1910 to 1971.[3] While statistics are scarce from those years on diabetes in pregnancy, it was reported that women who were diabetic before becoming pregnant-pregestational diabetes-could present with complications during pregnancy (miscarriages, congenital defects, fetal macrosomia, preeclampsia, fetal death, preterm and dystocic births, etc). It was also reported that such complications were more common in cases when treatment and control of the disease was inadequate.[4-6] In the 1960s, in Cuba and worldwide, diabetes in pregnancy affected approximately 1 in 1000 pregnant women.[7] In 1965, a study conducted in a Cuban maternity hospital corroborated the association between diabetes in pregnancy and fetal mortality.[8]

In the 1990s, gestational diabetes mellitus (GDM) affected a notable proportion of pregnant women in the United States and Latin America, with a prevalence in Latin America ranging from $1 \%$ to 14\%.[9-11] Cuba's first study on GDM prevalence, conducted in 1996 in a Havana community polyclinic catchment area, showed that $4.5 \%$ of pregnant women there suffered from the disease. While the study's limited sample could not be used to make inferences regarding national prevalence, it did provide an initial approximation to the problem and suggested that GDM could be a major health challenge for the country.[12] In 2005, WHO reported that GDM was $0.77 \%$ in Latin America, while Cuba's rate was the highest of all countries included in the study (1.75\%).[11]

To mitigate this problem, Cuban specialists conducted research and organized specialized health services. They worked to improve the quality of specialized medical care, research and education regarding diabetes in pregnancy through theoretical and methodological contributions.

\section{DEVELOPMENT}

When ALAD was founded, specialized medical practice for diabetes in pregnancy had been set up in Cuba; and in the early 1970s the first Diabetes and Pregnancy Service was established at the Ramón González Coro Maternity Hospital.[13] This specialized clinic improved the ability of Cuban specialists to continue making scientific and methodological contributions to the scientific community regarding the care and management of women with pregestational diabetes and GDM.

The founding of a Latin American association where experts from different countries could share information and experiences occurred in a moment when the disease's prevalence and incidence were rising. This created a favorable context for diabetes in pregnancy to be recognized as a particular problem demanding attention due to its repercussions on the reproductive health of women and the health of their children. Cuban professionals who were diagnosing and treating pregnant women with diabetes and carrying out research on the subject 
appreciated that ALAD offered an opportunity to disseminate the results of their work and extend them to other Latin American countries.

Cuban specialists found that pregnant diabetic women more frequently gave birth to children with congenital malformations (3:1 ratio).[14] Perinatal mortality was also higher among children of women with diabetes in pregnancy.[8,15] Such results confirmed findings by authors in other countries $[5,6,16]$ and enabled researchers to design guidelines for the metabolic and obstetric management of diabetes in pregnant women.[15]

Among these guidelines was insulin as the treatment of choice for diabetes during pregnancy, even if women took oral hypoglycemic drugs before pregnancy. The main argument put forward by the Cuban professionals was evidence of teratogenic effects of some oral hypoglycemic medications such as tolbutamide[17] and occurrence of neonatal hypoglycemia associated with its use, already documented by researchers in other countries.[18] For this therapy, they initially proposed a treatment regimen (pre-hypoglycemic) based on the Roversi gestational diabetes regimen, $[19,20]$ which was later replaced by the intensive or multi-dose insulin treatment plan currently used in Cuba. The regimen consists of administering rapid-action insulin before meals and intermediate-action insulin at night, ensuring optimal glycemic control and best pregnancy outcomes.[21,22] In 2007, ALAD's Latin American Consensus on Diabetes and Pregnancy (Consenso Latinoamericano de Diabetes y Embarazo de la ALAD) established insulin therapy as the standard for treatment of diabetes during pregnancy.[23]

Cuban specialists participated in preparing ALAD's clinical care guides for pregnant diabetics, with particular contributions to pre-conception care standards for diabetic women considering pregnancy, as well as control of their diabetes during pregnancy.[24] The theoretical and methodological foundation of Cuban professionals' contributions arose from their ongoing experience in monitoring and treating diabetic pregnant women in the Diabetes and Pregnancy Service of the Ramón González Coro Maternity Hospital and, from 1992, at the pre-conception care clinic for diabetic women at the Diabetes Care Center of Cuba's National Endocrinology Institute in Havana.[13]

Among others, their results showed the adverse effects of obesity at the start of pregnancy or excessive weight gain during pregnancy.[25-27]

Cuba's contribution to ALAD's care recommendations for pregnant diabetics once again consisted of developing guidelines for preconception care for diabetic women.[28] The first reports on the benefits of this care were published in the early 1990s [29-31] and introduced in Cuba in 1992, with the founding of a preconception clinic for diabetic women in Havana, the first of this type in the country.[13] Comparing pregnancy outcomes of diabetic women who had received this specialized primary health care and those who had not showed significant differences in prevalence of congenital defects (0.9\% vs. 9.6\%, respectively) and in perinatal mortality (0.9\% vs. $7.0 \%)$. Researchers presented new results on the association of initial excess weight (body mass index $\geq 26.1 \mathrm{~kg} / \mathrm{m}^{2}$ ) and excessive weight gain during pregnancy, with macrosomia and other adverse outcomes for pregnant diabetic women and their newborns. They also suggested preconception care for women with pregestational diabetes, laser therapy to treat diabetic retinopathy during pregnancy, and strict obstetric followup and antepartum fetal surveillance in pregnancies complicated by DM, among other recommendations.[32-34]

The benefits of preconception care, inserted into primary health care, were subsequently extended throughout Cuba, with national coverage of the Cuban Diabetes and Pregnancy Program (PCDE) launched in 2001.[35] Not all Latin American countries were able to establish such services, so Cuba maintained a leading role in management of diabetic pregnancies in the region.

Cuba was also in the leadership of the International Diabetes Federation's Working Group on Diabetes and Women in the South American/Central American/Caribbean Region when the Latin American and Caribbean Association of Sexual and Reproductive Health in Diabetes was recognized as an International Association of Diabetes and Pregnancy Study Groups (IADPSG)-affiliated scientific organization. Major actions carried out under this leadership include the proposal for Latin American member countries to create national health programs on diabetes and pregnancy, with Cuba's PCDE as a reference point. This proposal was based on the benefits attained by diabetic Cuban women through attention to the reproductive risk associated with diabetes, including preconception care for diabetic women and transdisciplinary care for pregnant women with diabetes.[13]

In 2007, Cuban specialists proposed ALAD recommend screening for congenital defects in fetuses of diabetic expectant mothers during the first half of pregnancy and for fetal macrosomia from the 28th week, both by ultrasound, as well as periodic obstetric monitoring of fetal health from the 34th week. These recommendations were included in a consensus document. Additional Cuban contributions included emphasis on the benefits of applying WHO's GDM diagnostic criteria,[23] which were adopted by ALAD with some modifications and are now being implemented.[36]

Cuban specialists demonstrated the value of fasting glycemia to screen for GDM and impaired glucose tolerance, in contrast to recommendations from the American Diabetes Association, namely using a glucose tolerance test with a load of $50 \mathrm{~g}$ of glucose. The range proposed as a risk marker for the disease was 4.4-5.5mmol/L.[37] This standard was included in the Latin American Consensus on Diabetes and Pregnancy in 2008 and in Cuba's PCDE disease-screening protocol.[23,35,37]

In 2014, the coverage of the 19 services of the transdisciplinary diabetes care network in pregnancy was $100 \%$ of mothers with gestational diabetes; $41 \%$ of whom were women undergoing preconception care for pregestational diabetes. Perinatal mortality in children of diabetic mothers was $4.8 \%$, congenital defects appeared in $4.3 \%$ of children in the program, and mortality in women with GDM was 24 per 100,000 population. Cuba was recognized by $\mathrm{PAHO}$ as one of the few countries in Latin America with a national program that included health promotion activities for diabetic women of reproductive age aimed at preventing GDM and reduce unfavorable pregnancy outcomes, a growing body of research in diabetes 
and pregnancy, and training of some 60 healthcare providers in this field. $[38,39]$

Cuban specialists showed that GDM also entails high risk of fetal macrosomia (one of the most common complications affecting children of diabetic mothers), and underscored the importance of early GDM diagnosis and intervention during pregnancy to prevent adverse outcomes.[40] They also made the case for diagnostic testing in the 26th week of pregnancy instead of the established practice of testing between the 28th to 32 nd week, thus allowing for earlier intervention. This proposal was approved by ALAD[36] and introduced in Cuba in 2017.[41]

In 2015, newborns of Cuban diabetic mothers had a low percentage of congenital defects $(2.5 \%)$. Perinatal mortality was also low $(2.9 \%)$ for newborns of women with pregestational diabetes (2008-2015). Other events with low relative frequencies in women with GDM in 2015 were: fetal macrosomia (6.0\%), premature births (3.1\%), low birth weight (4.0\%), perinatal mortality $(0.6 \%)$, and maternal mortality $(0.0 \%)$. Today, Cuba remains one of the few countries in Latin America with consistent and systematic preconception care, since the PCDE provides preconception care for women with pregestational diabetes, and prenatal care for diabetic women, diagnosis of GDM, and longterm monitoring of these women and their children.[42]

\section{CONCLUSIONS}

Cuban specialists have played an important role in early detection and prevention of congenital defects in children of diabetic mothers and on strict obstetric monitoring, prenatal fetal surveillance and identification of risk factors for fetal macrosomia, the most common complication in diabetic pregnancies. They recommended use of insulin for diabetic pregnancy management with specific treatment plans and promoted preventive use of insulin therapy in GDM. This contributed to significant improvements in health indicators of diabetic pregnant women in Cuba. Cuban proposals also led to new regional consensus recommendations in areas such as weight control according to initial weight and weight gain, as well as new guidelines for applying fasting blood glucose tests to screen for GDM.

The organization of health services under a specific national diabetes and pregnancy program inserted into primary health care proved to be an effective strategy in monitoring and controlling diabetes before conception, during pregnancy, and up to the time of delivery, an experience shared regionally.

Through dissemination of their research results and knowledge gained from their experience in management of women of childbearing age and diabetic women during pregnancy, Cuban specialists have made important contributions to defining standards and procedures to ALAD's, in treatment of diabetic pregnant women. $-1 /$ -

\section{REFERENCES}

1. García de los Ríos M. Historia de la Asociación Latino Americana de Diabetes (ALAD). 19702010. Rev Chil Endocrinol Diabetes [Internet]. 2011 [cited 2018 Sep 3];4(1):61-3. Available at: http://www.revistasoched.cl/1_2011/11-1_2011 .pdf. Spanish.

2. Cardonnet LJ. El pasado de la Asociación Latinoamericana de Diabetes. Rev ALAD. 1993;I (2):80-2. Spanish.

3. Valiente S, Behnke J. La diabetes mellitus como problema de salud en la América Latina y el Caribe. In: Grupo de Estudio sobre Diabetes Mellitus, editor. Publicación Científica No. 312. OPS. Oficina Sanitaria Panamericana, Oficina Regional de la OMS. Washington, D.C.: Pan American Health Organization; 1975. p. 19-27. Spanish.

4. Gabbe SG. A story of two miracles: the impact of the discovery of insulin on pregnancy in women with diabetes mellitus. Obstet Gynecol. 1992;79(2):295-9.

5. Hadden DR. History of diabetic pregnancy. In: Moshe $\mathrm{H}$, Jovanovic L, Di Renzo GC, De Leiva A, Langer $\mathrm{O}$, editors. Textbook of Diabetes and Pregnancy. London: Informa Healthcare; 2008 Mar 4. p. 1-8.

6. Karter H. The early years. In: Karter H. A history of diabetes in pregnancy. The impact of maternal diabetes on offspring prenatal development and survival. Springer: New York; 2012. p. 7-9.

7. Márquez A, Valdés L. Diabetes y embarazo. En: Mateo de Acosta O. Diabetes Mellitus. Havana: Ciencia y Técnica; 1971. p. 355-92. Spanish.

8. Márquez A. Síndrome prediabético, su importancia como causa de muerte fetal en nuestro hospital. Rev Cubana Med. 1965:4:22-39. Spanish.

9. Coustan DR. Gestational diabetes. In: National Diabetes Data Group, editor. Diabetes in America. Maryland: National Institutes of Health and National Institute of Diabetes and Digestive and Kidney Diseases; 1995. p. 703-17.

10. Lawrence JM. Prevalence of GDM. In: Kim C, Ferrara A, editors. Gestational diabetes mellitus during and after pregnancy. Springer: London 2010. p. 53-69.

11. Voto LS, Mattioli MJ, Uranga M. Gestational Diabetes in Latin America. In: Moshe $\mathrm{H}$, Jovanovic L, Di Renzo GC, De Leiva A, Langer O, editors. Textbook of Diabetes and Pregnancy. London: Informa Healthcare; 2008 Mar 4. p. 132-4.

12. Márquez A, Aldana D, Rodríguez BR, González ME, Lang J, Pérez L, et al. Prevalencia de diabetes gestacional en un área de salud de Ciudad de La Habana. Rev ALAD. 1996; IV(2):75-80. Spanish.

13. Cruz J, Márquez Guillén A. Historia de la diabetes y embarazo en Cuba después de 1959. Rev Cubana Salud Pública [Internet]. 2019 Dec 31 [cited 2020 Jan 22];45(4). Available at: http://www. revsaludpublica.sld.cu/index.php/spu/article/ view/1701/1339. Spanish.

14. Valdés LA, Márquez A, Santana O, Rodríguez B, Cuevas E, Sánchez C. Las malformaciones congénitas en hijos de madres diabéticas (estudio de 1064 nacimientos consecutivos): II parte y final. Rev Cubana Obstet Ginecol. 1991;17(2):86-100. Spanish.

15. Márquez A. Diabetes y embarazo. En: Orientaciones Terapéuticas. Ginecología No. 1. Havana: National Information Center for Medial Sciences (CU); 1968. Spanish

16. Karter $\mathrm{H}$. The framework. In: Karter $\mathrm{H}$, editor. A history of diabetes in pregnancy. The impact of maternal diabetes on offspring prenatal development and survival. Springer: New York; 2012. p. 3-6.

17. Márquez A, Valdés LA. Valoración del efecto teratogénico de los compuestos orales hipoglicemiantes en el tratamiento de la gestante diabética. Rev Cubana Obstet Ginecol. 1977;3(3):231-40. Spanish.

18. Langer $\mathrm{O}$. Oral anti-diabetic agents in pregnancy: Their time has come. In: Moshe $\mathrm{H}$, Jovanovic L, Di Renzo GC, De Leiva A, Langer O, editors. Textbook of Diabetes and Pregnancy. London: Informa Healthcare; 2008 Mar 4. p. 217-27.
19. Roversi GD, Gargiulo M, Nicolini U, Pedretti E Marini A, Barbarani V, et al. A new approach to the treatment of diabetic pregnant women. Report of 479 cases seen from 1963 to 1975. Am J Obstet Gynecol [Internet]. 1979 [cited 2020 Jan 22];135:567-76. Available at: https://doi .org/10.1016/S0002-9378(16)32978-7.

20. Roversi GD, Gargiulo M, Nicolini U, Ferrazzi E Pedretti E, Gruft L, et al. Maximal tolerated insulin therapy in gestational diabetes. Diabetes Care [Internet]. 1980 [cited 2020 Jan 22];3(3):489-94. Available at: https://doi.org/10.2337/diacare.3.3 .489

21. Valdés L, Márquez A, Rodríguez BR. Tratamiento de la diabetes gestacional: dieta o dieta e insulina. Rev ALAD. 1998; VI(2):110. Spanish.

22. Lang J, Márquez A, Santana O, González MA, Zaldívar O, Rodríguez BR, et al. Estudio comparativo de tres esquemas de tratamiento insulínico en la gestante diabética. Spanish. Rev ALAD. 1998; $\mathrm{VI}(2): 110$.

23. Colectivo de autores. Consenso Latinoamericano de Diabetes y Embarazo. Rev ALAD [Internet]. 2008 [cited 2018 Sep 3];XVI(2):55-69. Available at: http://www.revistaalad.com/files/08 02concensos_al.pdf. Spanish.

24. Latin American Diabetes Association (ALAD) Normas de atención a la diabética embarazada Seminario ALAD. Mendoza. Argentina. 9 y 10 de mayo de 1994. Rev ALAD. 1994;II(2):6-26. Spanish.

25. Rodríguez BR, Valdés L, Pérez J, Márquez A, Lang J, González MA. Efecto del peso al inicio del embarazo sobre la morbilidad y la mortalidad materna y perinatal en diabéticas gestacionales. Rev Cubana Endocrinol [Internet]. 1997 [cited 2018 Sep 3];8(1):79. Available at: http://bvs.sld .cu/revistas/end/vol8_1_97/end07197.pdf. Spanish.

26. Rodríguez BR, Valdés L, Pérez J, González MA, Lang J, Llibre N, et al. Relación entre la ganancia de peso materna y algunas eventualidades 
obstétricas y perinatales en diabéticas gestacionales. Rev Cubana Endocrinol [Internet]. 1997 [cited 2018 Sep 3];8(1):80. Available at: http:// bvs.sld.cu/revistas/end/vol8_1_97/end07197 pdf. Spanish.

27. Rodríguez B, Valdés L, Castellanos L, Festaris A, Santana O, Santurio A, et al. La malnutrición materna por exceso o por defecto en diabéticas gestacionales. Resultados maternos y perinatales. Rev ALAD [Internet]. 2007 [cited 2018 Sep 3];XV(3):130. Available at: http://www.revistaalad .com/pdfs/070304ec.pdf. Spanish.

28. Colectivo de autores. Consenso ALAD sobre la atención a la diabética embarazada aprobado en Mendoza, 1994 y modificado en Cancún, 1997. Rev ALAD. 1997;V(4):223-34. Spanish.

29. Steel JM, Johnstone FD, Hepburn DA, Smith AF. Can prepregnancy care of diabetic women reduce the risk of abnormal babies? BMJ. 1990 Nov 10;301(6760):1070-4.

30. Rosenn B, Miodovnik M, Combs A, Khoury J, Siddigi TA. Pre-conception management of insulin-dependent diabetes: improvement of pregnancy outcome. Int J Gynecol Obstet. 1991 May;38(1):846-9.

31. Kitzmiller JL, Gavin LA, Gin GD, Jovanovic-Peterson L, Main EK, Zigrang WD. Preconception care of diabetes. Glycemic control prevents congenital anomalies. JAMA. 1991 Feb 13;265(6):731-6.

32. Márquez A, Lang J. Salud reproductiva y diabetes mellitus. Rev Cubana Endocrinol. 2000;11(2):61-2. Spanish.

33. Márquez A. Salud reproductiva en diabetes. I Congreso Internacional de Salud Reproductiva en Diabetes Mellitus "SAREDIA 2000". Varadero, Cuba, 14 de noviembre de 2000. Rev Cubana Endocrinol. 2000;II(Suppl):7. Spanish.

34. Sociedad Cubana de Endocrinología, Sociedad Cubana de Diabetes, Sociedad Cubana de Medicina y Salud Reproductiva, Instituto Nacional de Endocrinología. I Congreso Internacional de Salud Reproductiva en Diabetes Mellitus "SAREDIA 2000"; Varadero, Cuba. Carteles. Rev Cubana Endocrinol. 2000;II(Suppl):23-77. Spanish.

35. Valdés Amador L, Lang Prieto J, Rodríguez Anzardo BR, Santana Bacallao O, Zaldívar Guer- ra O, Santuario Gil A, et al. Programa Nacional de Atención a la Gestante con Diabetes [Internet]. Havana: National Institute of Endocrinology (CU); 2001 [cited 2018 Sep 3]. 10 p. Available at: http://files.sld.cu/boletincnscs/files/2009/07/ respub2009drmarquezguillen.pdf. Spanish.

36. Colectivo de autores. Guías de diagnóstico y tratamiento de diabetes gestacional. ALAD 2016. Rev ALAD [Internet]. 2016 [cited 2019 Jan 19];6:155-69. Available at: http://www.revistaalad .com/files/alad v6 n4 155-169.pdf. Spanish.

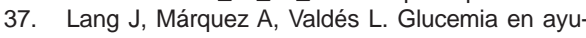
nas como instrumento en la pesquisa de la diabetes gestacional. Rev ALAD [Internet]. 2007 [cited 2018 Jul 19];XV(3):130. Available at: http://www revistaalad.com/pdfs/070304ec.pdf. Spanish.

38. Pan American Health Organization; World Health Organization. Hiperglucemia y embarazo en Las Américas. Informe final de la Conferencia Panamericana sobre Diabetes y Embarazo. Lima (Perú), 8-10 septiembre de 2015 [Internet]. Washington, D.C.: Pan American Health Organization; 2016 [cited 2018 Sep 3]. Available at: http://iris.paho.org/xmlui/bitstream/ handle/123456789/28207/9789275318836_spa .pdf. Spanish.

39. Cruz J, Lang J, Márquez A, Valdés L. Care for pregnant diabetics in Cuba: achievements and challenges. MEDICC Rev [Internet]. 2013 Jul [cited 2020 Jan 22];15(3):38-41. Available at: http:// mediccreview.org/wp-content/uploads/2018/04/ mr_316.pdf

40. Poster presentations. Session C: GDM management and follow up. In: International Association of the Diabetes and Pregnancy Study Groups (IADPSG). Scientific IADPSG Meeting 2016 March 21-23; Buenos Aires, Argentina. Abstracts of the lectures, hot topics, workshop, clinical updates, oral presentations and poster presentations presented at IADPSG Meeting 2016. Rev Soc Argentina Diab [Internet]. 2016 [cited 2018 Sep 3];50(Special issue - Scientific IADPSG Meeting 2016):46. Available at http://www.diabetes.org.ar/media/attachments/ 2018/01/29/especial-iadpsg.pdf

41. Cruz J, Piloto M. Segundo Consenso Cubano de Diabetes y Embarazo. Rev Cubana Endo- crinol [Internet]. 2018 [cited 2020 Jan 22];29(1). Available at: http://www.revendocrinologia.sld .cu/index.php/endocrinologia/article/view/97/86. Spanish.

42. Cruz J. Acta de la II Conferencia Panamericana de Diabetes y Embarazo (CPDE). Diabetes y Embarazo en América Latina. Havana: Pan Amerian Health Organization; World Health Organization; 2016. Spanish.

\section{THE AUTHORS}

Jeddú Cruz-Hernández (Corresponding author: celsocruz@infomed.sld.cu), physician with dual specialties in family medicine and endocrinology and master's degrees in comprehensive women's health care, atherosclerosis research and diagnostic procedures in primary health care. Professor and associate researcher, and head of Diabetes and Pregnancy Working Group, Center for Comprehensive Diabetes Care of the National Endocrinology Institute (INEN), Havana, Cuba.

Antonio Márquez-Guillén, endocrinologist with a doctorate in medical sciences. General coordinator, Cuban Program on Diabetes and Pregnancy (PCDE). Full professor and senior researcher, INEN, Havana, Cuba.

Jacinto Lang-Prieto†, endocrinologist. Professor and associate researcher, INEN, Havana, Cuba.

Ileydis Iglesias-Marichal, physician with dual specialties in family medicine and endocrinology, with a master's degree in urgent care. Director, INEN, Havana, Cuba.

Submitted: August 5, 2019

Approved for publication: October 4, 2020 Disclosures: Jeddú Cruz-Hernández is the current $A L A D$ delegate for Cuba. 


\section{La voz de una enfermera desde la zona roja}

\section{Paula Guerra-Librero de Hoyos}

Mi nombre es Paula. Nací en Madrid en 1995. Al acabar el bachillerato tenía muchas dudas sobre hacia dónde encaminar mi vida. Pensé qué hacer y qué se me daba bien o con qué era feliz. El caso es que desde siempre me ha gustado poco ser protagonista, pero me encantaba escuchar, conocer el más allá de la gente cuando se sentían en confianza de contarme. Me sentía bien siendo receptora de sus historias, sus sentimientos y sus vidas. Además, siempre me gustaron las ciencias, la química, las matemáticas, la biología... así que vi que la combinación perfecta para elegir carrera tendría que ser algo relativo a las ciencias de la salud: ciencias y personas en uno. Es entonces cuando pensé en la enfermería. Tenía ciencias, tenía personas y sobre todo tenía ese valioso tiempo cerca de las personas para acompañar y cuidar. Siempre me gustó ese dicho: la enfermera cuida, no cura.

Estudié enfermería en la Universidad Autónoma de Madrid. En esa etapa me fui de casa, trabajé de profesora particular, hice voluntariado en hospitales acompañando a personas mayores, sufrí con algunas asignaturas y me abrieron la mente otras, inicié un proyecto de investigación, hice prácticas en ámbitos muy distintos con tutoras y pacientes que marcarán para siempre mi forma de ver la enfermería... y viajé. Conocí Nepal, Cuba, Croacia, Marruecos, Alemania, Egipto, Irlanda, Jordania... me descubrí un poco más y crecí.

Acabé mis estudios en mayo de 2019 y, pocos días después de presentar mi trabajo de fin de grado, me llamaron para empezar mi primer contrato: Unidad de Cuidados Intensivos (UCl) Postquirúrgicos en el Hospital Universitario Puerta de Hierro. Estuve cuatro meses allí, uno esperando un nuevo contrato y de nuevo me llamaron de la $\mathrm{UCl}$ a finales de noviembre: esta vez la $\mathrm{UCl}$ Médica del mismo hospital. Suman ya un total de ocho meses de experiencia laboral, todos ellos en UCI y este último mes en "UCI COVID".

Y aquí empieza la historia de este testimonio. Yo, como otros tantos, me he convertido en "sanitaria frente al COVID". Lo cierto es que me siento afortunada en relación con otros compañeros: soy joven, no me han cambiado de unidad ni de hospital al empezar la reorganización en la pandemia, conocía la UCI y a los compañeros, sabía (desde mi corta experiencia) cómo trabajar, cómo funcionaba el equipo, cómo eran los pacientes de $\mathrm{UCl}$, las medicaciones, los respiradores... La capacitación en EPI (Equipo de Protección Individual) la hice con al menos una semana de antelación al primer caso que traté. Esto parecería lo mínimo a cumplir para trabajar bien, disminuir los riesgos hacia el paciente y hacia nosotros mismos, pero en realidad duró esa semana y actualmente algo así sería un regalo. Todo esto me hace sentir en una situación privilegiada y soy consciente de ello, pero espero, con estas pocas líneas, poder dar voz a muchos de mis compañeros y sus bien distintas situaciones.
El primer caso confirmado de COVID 19 en la Unidad de Cuidados Intensivos de nuestro hospital llegó la primera semana de marzo. Tras éste vinieron muchos más.

\section{La preparación para atender pacientes con Covid-19 en cuidados intensivos}

Meses atrás habíamos visto y oído lo que estaba ocurriendo en China y semanas antes lo que acontecía en Italia, pero el ser humano es ingenuo por naturaleza. Hasta que no llegaron los primeros casos a las urgencias de nuestro hospital no empezó el sistema a ponerse en marcha. Fueron semanas de caos.

Una semana antes del primer ingreso en nuestra $\mathrm{UCl}$, la supervisora de enfermería de la unidad nos informó hora y fecha para acudir a la clase de formación de "puesta y retirada de EPIs". Acudimos diez personas por la mañana y ocho por la tarde de una plantilla de alrededor de 100 enfermeros y 50 auxiliares. Todo fue más rápido de lo imaginado y cuando los primeros casos ya estaban en la $\mathrm{UCl}$, apenas una cuarta parte de la plantilla había asistido y, claro, "para atender pacientes con COVID-19 era obligatorio haber acudido a la formación". Era una charla de escasos 15 minutos que en cinco días pasó de ser voluntaria a ser obligatoria, por lo que se concentraban grupos de hasta 20 personas para recibir dicha formación y repasar su contenido en los pasillos del hospital mientras pasaban los siguientes. A este ritmo, al acabar esa semana la UCI ya estaba al completo: de enfermeras "capacitadas" y de pacientes.

En esa formación nos enseñaban qué ponernos, cómo y sobre todo, los pasos para retirar las protecciones sin contaminarnos. Pero este protocolo duró con las bases establecidas menos de una semana. Según pasaban los días, fuimos nosotros, el equipo que estábamos a pie de cama, los que nos íbamos haciendo 
preguntas: ¿Y el pelo?, ¿y los zapatos?, ¿y al quitarse los guantes?,... Con todas esas preguntas y los comentarios de compañeras de lo que se hacía en otros hospitales o en otros países, fuimos ampliando nuestros protocolos. Todo dentro de la disponibilidad de materiales que teníamos y tenemos, claro... Porque las utopías son imposibles en estos días, pero leyendo, contrastando evidencia en artículos ya publicados y planteando lo que sería más adecuado, se nos han ido ocurriendo formas de acercarnos a esos modos de acción y de mejorar lo que en un principio nos dijeron.

\section{La jornada de trabajo}

En dos semanas la UCl duplicó sus camas. Lo que empezó en la UCl médica con un máximo de 2 camas, ha acabado ampliándose a la UCl quirúrgica y a un módulo de "cuidados intermedios" que se ha habilitado en una zona que antes era el archivo del hospital. En total hay ahora 52 camas de UCI y unas 40 de cuidados intermedios. urgencia, y dado que estamos en la UCI no es raro que ocurran, no podemos esperar a vestirnos, tenemos que estar preparadas para actuar, al menos una, mientras el resto se viste, avisa al resto de equipo o prepara la medicación. En el último turno, las dos enfermeras que se quedaron antes fuera, realizan la última ronda de constantes, medicación, cambio de perfusiones, ajuste de respiradores, drogas y analíticas. Con ello acabamos el turno habiendo gastado ocho EPIs (sumando los dos de las auxiliares y el del celador) y habiéndonos expuesto menos de cuatro horas por turno cada uno de los allí presentes.

Pero una vez más, esto es lo utópico de la organización, muchas veces y más en estos servicios, surgen imprevistos y acabamos vestidas con los equipos de principio a fin del turno, ocho horas en pie, trabajando sin parar enfundadas en esas batas, mascari-llas, gafas, máscaras, guantes y gorros que nos hacen irreconocibles y nos mantienen ajenas a la realidad de cómo estamos hasta que salimos y vemos las marcas en la cara, los dedos arrugados, el

Definitivamente no sólo hemos cambiado las formas de trabajo, sino también el equipo de trabajo, el material con el que trabajamos, los fármacos de los que disponemos y el trato o contacto con el paciente. Quizá sea esto último lo que más me ha costado, ya que se parece muy poco a la forma de trabajar de una $\mathrm{UCI}$ en tiempos normales: entramos una o dos veces por turno al box del paciente, intentando disminuir el gasto de EPIs y la exposición del personal al virus. Para que esto funcione y la calidad de los cuidados se mantenga es imprescindible formar equipos y actuar como tal durante el turno.

La UCl está organizada en áreas de diez pacientes para cinco enfermeras, dos auxiliares de enfermería y un celador (que rota por dos áreas). Repartimos los pacientes según el ratio habitual (dos pacientes por enfermera) pero luego hacemos dos equipos, cada uno de dos enfermeras y una auxiliar, y según la carga asistencial de los pacientes, la tercera enfermera se une a uno u otro equipo. Después decidimos quién entra en cada uno de los dos

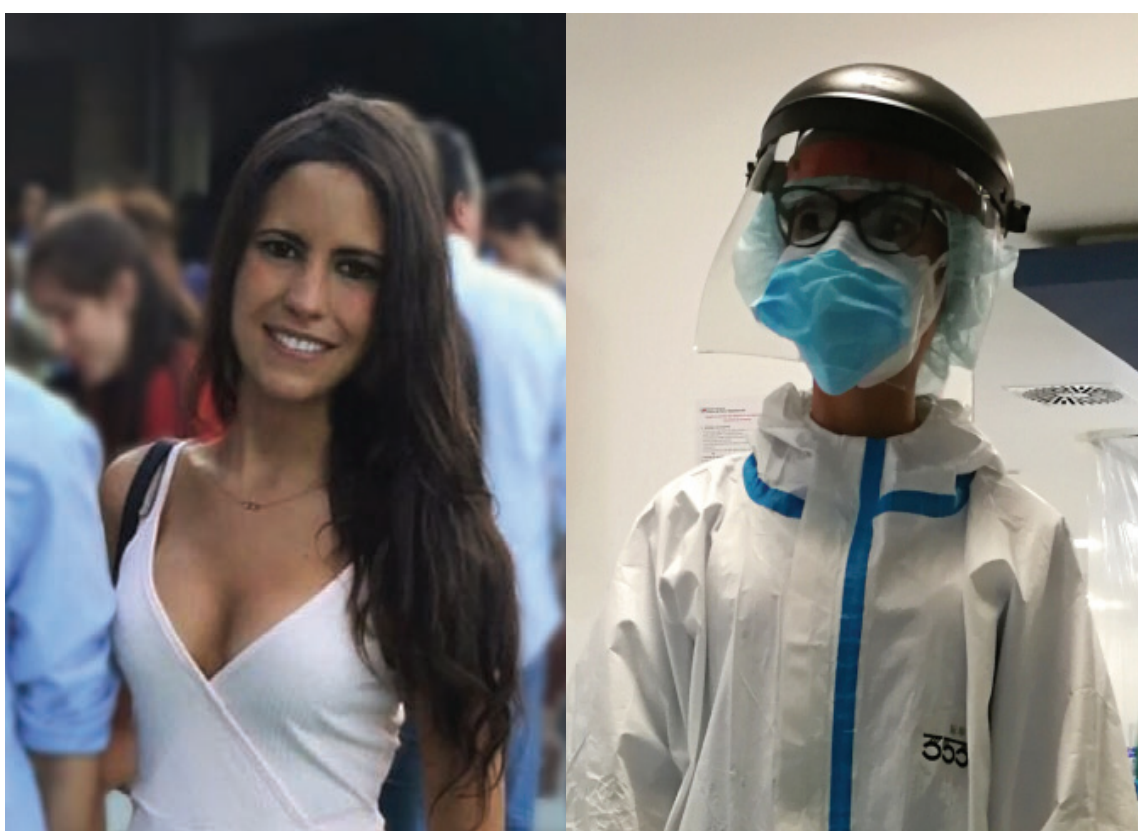

Irreconocible turnos programados. En el primer turno entra una enfermera de cada equipo y la tercera. Entre las tres hacemos un primer chequeo de las constantes de todos los pacientes, valoramos su estado general, hablamos un poco con los que no están sedados (pocos, ya que en cuanto mejoran les pasan al área de "intermedios"), mentalmente repasamos las mil cosas que les rodean, damos la medicación (que preparamos antes o preparan las que se quedan fuera) y realizamos los cuidados: curas, cuidados de tubo o tráqueo, cambios de sistemas, movilizaciones y cambios posturales (muchos pacientes mejoran en decúbito prono y movilizar a pacientes críticos, intubados y sedados en esta postura lleva preparación, tiempo y riesgo).

Tras este primer turno, donde las dos enfermeras que se quedan fuera nos asisten con los materiales de curas, sábanas o medicación que nos falte de la zona "limpia", son ellas las que entran. Suele haber algo de tiempo entre una entrada y la siguiente, coincidiendo todas en la "zona limpia", lo cual permite planear la segunda entrada y comentar novedades a los médicos, pero siempre ha de quedarse alguna vestida: si ocurre una sudor en los pijamas y las piernas entumecidas. Son turnos duros, pero que, gracias al trabajo en equipo, gracias a que la compañera de al lado cuida de tus pacientes un rato y viceversa, podemos turnarnos, beber agua, cambiar de actividad, reducir la exposición y, sobre todo, lo que más interesa a gestores y supervisoras, gastamos menos material.

Durante el trabajo es una mezcla enorme de emociones la que hay concentrada. Ha habido días alegres donde el paciente al que atendía empezaba a mostrar un mínimo de confianza después de días de miedo; días donde, por fin, pacientes que llevaban tiempo dormidos reaccionaban a ese contacto "guante con guante"; días incluso en los que todos ellos bajaban a planta, nos despedíamos y estaban un paso más cerca de volver con los suyos. Igualmente intensos, otros días eran duros, había cansancio en el equipo, los pacientes no avanzaban, te ibas teniendo la sensación de no dejar las cosas bien hechas, de no haber cuidado como deberías; días en los que al entrar en la sala de espera veía a una persona vestida de calle, un familiar, solo uno. Y es que cuando un paciente COVID positivo fallece es el único momento en el que el 
familiar puede acceder a la UCI. Es un momento muy duro, entran con mascarilla y bata a ver a su familiar (con mascarilla también pero que ya no respira) y no pueden tocarle en ningún momento. Cinco minutos y se lo llevan. Es un dolor enorme y un sentimiento de soledad inmenso. Como comunidad vamos a necesitar mucha ayuda en estos duelos cuando esto acabe...

Todo esto se mezclaba incluso en el mismo día. Llevabas un paciente al lado de otro, sonrías con los ojos al que se iba a planta, le dabas una de las cartas para que la leyese al llegar y al darte la vuelta te acercabas, como podías, al familiar del que ya no estaba, otra vez guante sobre guante, viendo esos ojos sobre la mascarilla...

Muchas, muchas emociones. Ojalá se entiendan un poco y sirva para otros, para que la gente siga cobrando conciencia y se quede en casa, para que otros sanitarios se sientan comprendidos, para que veamos lo necesaria que es la sanidad pública y el trabajo en equipo y, por supuesto, para que pacientes y familiares vean también que hay personas y sentimientos detrás de esas batas y que seguiremos a pie de cama con ellos hasta que todo esto pase.

\section{Trabajar en condiciones de riesgo biológico}

El riesgo está ahí desde el primer día del primer ingreso. Al principio el agotamiento -sobre todo mental- era enorme. Muchas cosas nuevas, muchos nervios generalizados, miedo de algunos, orgullo de otros y momentos de reivindicación de la mayoría. Poco a poco, con el paso de los días hemos aprendido qué hacer y cómo con este tipo de pacientes. Los médicos tienen sus algoritmos más establecidos, las auxiliares saben qué limpiar y cómo y tenemos el material disponible casi al instante, las enfermeras hemos logrado organizarnos por equipos y saber cómo llevar a cabo los cuidados de $\mathrm{UCI}$ reduciendo tiempos, material y personal. Sabemos el qué, cómo y cuándo y eso da seguridad.

Esa incertidumbre que agotaba las energías de los primeros días ha disminuido algo al conocer la respuesta a esas preguntas, pero los días van pesando, las horas de trabajo, los turnos con imprevistos, calmar los ánimos del equipo, intentar que todos sigamos siendo uno, enseñar al nuevo personal que entra por aquellos que se van de baja, que caen... todo ello es el nuevo cansancio de estos días.

Al principio había mucho miedo y muchas dudas. Veíamos que había diferentes formas de protegerse, de quitarse el traje, de usar las mascarillas, etc. Todo eso se protocolizó a partir de la segunda semana. Nos informamos, hicimos una especie de equipo de investigación improvisado, leímos mucho y compartimos mucha evidencia. Recuerdo usar cada rato en el transporte público para leer cuatro o cinco artículos e ir haciendo resúmenes y cogiendo ideas para "nuestro protocolo", llegar a casa y hacer guías con fotos para imprimir allí y tenerlas a mano. No desconectaba al volver a casa. Todo esto reforzó el conocimiento conjunto del por qué hacíamos esto o lo otro, de tal forma o tal otra. El grupo de Whatsapp de trabajo echaba humo esos primeros días y estábamos todas al tanto de las novedades, pero a veces eran demasiadas...

Por otro lado, en cuanto a la parte práctica al comienzo de la pandemia al iniciar todo con menos casos, nos "vigilábamos" unas a otras en la retirada de los equipos de protección individual. Eran muchas cosas en la cabeza las que teníamos al salir de los box con el traje: salíamos saturadas, con la adrenalina del estrés por las nubes y con la sensación de dejar cosas pendientes (ahora no podíamos salir y de pronto decir "ah, se me ha olvidado esto, vuelvo", no, teníamos que estructurar mucho cada entrada y acostumbrarnos a esta nueva forma de trabajo), por lo que tener una compañera que, desde fuera, nos iba recordando los pasos de retirada del EPI, nos daba la calma para acabar ese proceso, para no fallar en la parte más importante y cuando más se notaba el cansancio, se agradecía mucho.

Mi primer día a cargo de una paciente con COVID apenas cuatro enfermeras habían estado antes. Había solo dos pacientes con coronavirus ingresados y el resto eran pacientes críticos "habituales". Había solo dos, pero mi ansia por saber me hacía estar un paso por delante de mis compañeras: había acudido a la capacitación y quien no había acudido aun no podía atender a estos pacientes. Hicimos el reparto y me dijeron que la atendería yo. Mi mayor miedo al saber que iba a ser yo la que entrase y cuidase a pie de cama era mi inexperiencia en cuidados intensivos.

Con cinco meses en la UCl te manejas, pero estás muy lejos de controlar como quien lleva diez años. $Y$ siento que seguiré preguntando y dudando mucho tiempo aún, cosa que por otro lado es normal, sensato y hasta responsable. Mis tutoras en las prácticas siempre me lo decían: "malo es el que sale de un turno sin tener ninguna duda" y es que si no dudas, si no preguntas y te lanzas sin saber... son vidas las que están en nuestras manos.

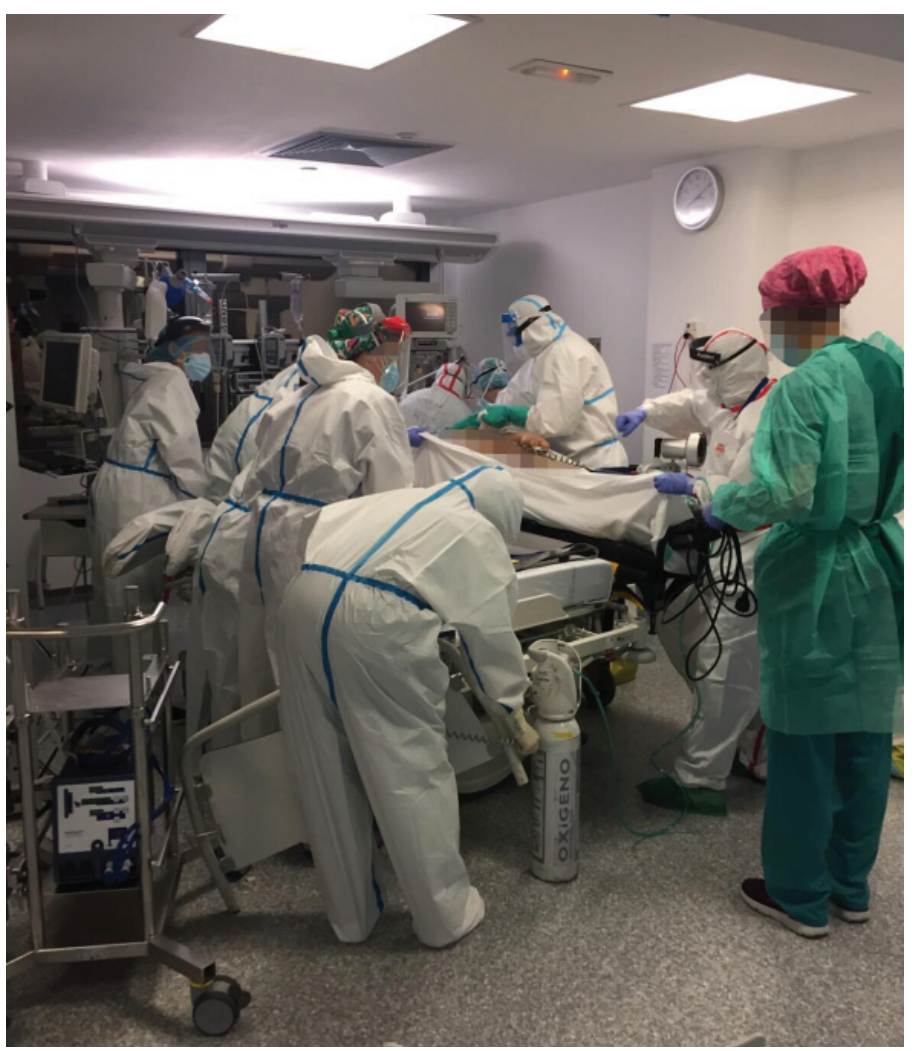

La llegada de un paciente. Un paciente ingresa en la UCl, proveniente de otro hospital más pequeño, para recibir ahora asistencia respiratoria. Alrededor del paciente, todo el equipo. Todos, igual de importantes: celador, enfermeras, médicos intensivistas y auxiliar de enfermería. Todos bajo la enorme presión psicológica de saber que esa vida depende de tí, de lo que haces en cada instante y de si lo haces bien. De si sabes leer el más pequeño signo que alerte al equipo de que algo anda mal. 
Las UCls son unidades en las que, ante una urgencia, la enfermera de al lado acude a ti, normalmente las antiguas te echan una mano sean o no "sus" pacientes los que se han puesto malos. Se forma un grupo de dos o tres enfermeras según la urgencia y, la situación, sea la que sea, se lleva mejor por el gran equipo que se hace en esos momentos. Volviendo a mi primer contacto con COVID-19, la paciente que iba a atender había tenido un paro cardíaco por la mañana, tuvieron que despronarla ${ }^{1}$, hacer masaje cardíaco, revertir la parada con el desfibrilador y luego volverla a pronar. Yo pensaba que si toda esa situación se repetía en mi turno ¡mi menor problema sería el COVID o los EPIs! La única premisa que puse para yo hacerme cargo de esa paciente fue entonces que, si sucedía cualquier urgencia, alguna de las enfermeras antiguas se vestiría conmigo. Chus fue la primera en adelantarse y decirme que por supuesto, que el COVID es el COVID pero también la $\mathrm{UCl}$ es la $\mathrm{UCl}$ y que en ningún momento me dejarían sola. Así fue. Al final no sucedió nada urgente y no tuvo que entrar conmigo, pero estuvo fuera, al otro lado de la línea roja que separa lo "limpio de lo sucio", pendiente en todo momento de si necesitaba algo. Una vez más: el equipo.

Después de esos primeros días seguimos formándonos y ayudándonos. Es cierto que se dice que al habituarnos a la situación hay riesgo de disminuir las precauciones pero, por otro lado, que se hayan establecido ya las formas de hacer las cosas facilita la concentración, no tenemos tantas cosas en la cabeza y cuando las hacemos, sabemos los porqués.

Al haber bajas y haber aumentado el número de camas han contratado a gente nueva o reubicado personal de otras zonas del hospital. Quizá el mayor riesgo ahora de cometer fallos esté aquí. Como me pasó a mí, cuando llegas nueva a la UCI agradeces que alguien te vaya poniendo al día, te cuente el funcionamiento de la unidad y lo aprendido estas semanas de los pacientes con COVID y sus cuidados. Así que, aunque todo esté ya protocolizado, hay que explicarlo, enseñarles, asumir parte de su trabajo en los primeros turnos... y quizá a alguien con mucha destreza en UCI no le sea difícil, pero yo he pasado de ser una de las nuevas a una de las "veteranas" con el movimiento de personal durante el COVID y eso está más bien lejos de la realidad. Requiere una concentración extra que dificulta centrar la atención en los " $A B C$ " que se habían establecido, pero cada uno saca sus herramientas. En mi caso, siempre que me toca con alguien nuevo, primero les aviso que yo también soy nueva y les digo que voy a ir verbalizando lo que hacemos, lo que vamos a hacer y el cómo lo vamos a llevar a cabo. Así funcionamos con beneficios dobles: la persona que acaba de llegar va cogiendo rodaje, escuchando los porqués y qué se hace y a la vez yo, si por casualidad me confundo o se me olvidan cosas, con esto hago repasos en voz alta, me escucho a misma y corrijo o recuerdo según cual sea el caso.

La verdad es que está siendo increíble ver cómo la gente, con una semana de rodaje, están ya controlando, funcionando. Eso y lo que se agradece que vengan de sus servicios a echar una mano y a trabajar hombro con hombro durante semanas. Ojalá se recuerden estas cosas cuando todo esto acabe.

\section{Retos para la vida personal y familiar}

Lo de ser protagonista nunca ha sido mi fuerte y cuando me propusieron dar mi testimonio me puse nerviosa, pero luego pensé: dar voz es la mejor forma de hacernos ver y yo no soy

1. Sacar al paciente de la posición decúbito prono para representativa de todo lo que está pasando, me siento una privilegiada, pero creo que si me dan la opción no podía rechazar dar voz también a mis compañeras.

Desde hace unos tres años vivo fuera de la casa de mis padres. Actualmente comparto piso con Álvaro, mi pareja, también enfermero y Cristian, estudiante de abogacía de 23 años, de Tenerife y que ha venido este año a estudiar a Madrid. Somos jóvenes y sanos, no somos personas de riesgo. Esto creo está siendo la peor pesadilla de algunas compañeras: miedo a llevar el "bicho" a casa, a contagiar a padres, marido, hijos con alguna patología o incluso contagiarse ellas mismas. Yo no tengo niños ni abuelos de los que hacerme cargo al volver a casa, no tengo ese miedo ni ese plus de responsabilidad a las espaldas, pero, repito, no es lo normal. Hay compañeras que se han mudado a los hoteles que ofertan para profesionales de la salud durante la pandemia, otras que han pedido a su pareja que se vaya a vivir con sus padres y así no verles, otros que hacen tetris con los turnos para cuidar de los niños que se quedan en casa porque ambos son sanitarios y "no encuentran a nadie que quiera cuidar en estas fechas al hijo de una enfermera"... Y, como estos, mil casos, mil vidas y mil soluciones que han ido encontrando para sobrellevar estas semanas. Me siento afortunada de que me haya tocado en la situación en la que estoy y me lo recuerdo cada día que voy a trabajar y escucho sus odiseas y sus miedos.

\section{Los aplausos en la noche}

La primera noche de aplausos la viví en el hospital. Estaba trabajando, por lo que la primera noticia de esta gran revolución social la obtuve a través del móvil de una compañera al acabar el turno. Uno de los tantos vídeos que ese día circularon por nuestros teléfonos, donde desde un balcón se grababa al resto, con familias enteras asomadas aplaudiendo. Jamás había visto algo así en Madrid. Aun en video fue emocionante, se me erizó la piel, lo primero que hice fue mirar a los pacientes y pensar si sus familias también estarían detrás de estos aplausos. Al instante pensé que más bien deberían estar entre los que los reciben. Nosotros por estar con sus familiares y ellos por todo lo contrario, por estar lejos aun con la enorme dificultad emocional que conlleva. El primer día que desde casa los vi en directo en los balcones y aplaudí con ellos no pude contener la emoción.

Pero, acompañando a los aplausos, comparto con todos unas palabras de Elena Plaza, enfermera en docencia y gestión, que hace podcast y siempre habla muy claro:

No somos héroes, somos personas. Nuestras marcas de guerra son nuestras ojeras y las que no se ven: las que tenemos en el alma.

No somos héroes, somos personas, y estamos trabajando por encima de nuestras posibilidades. Necesitamos descansar.

No somos héroes, somos profesionales sanitarios, y no sanitarios también, que también nos contagiamos. Caemos como moscas por la falta de EPIS o demasiadas horas con él puesto y al final cometes algún error.

No somos héroes, somos personas con una vida como la tuya. No nos podemos quedar en casa y tenemos que volver a ella con el miedo de contagiar a nuestros familiares.

No somos héroes, somos trabajadores maltratados desde siempre, con un sistema de bolsa de MIERDA, sueldos de mierda y con una responsabilidad enorme a nuestras espaldas: vidas humanas. 
No somos héroes, estamos mal, necesitamos ayuda psicológica. Porque esto no hay Dios que lo aguante. No somos héroes ni magos, aunque estemos sacando camas de la chistera y gestionando recursos materiales y prácticos, haciendo malabares.

NO SOMOS HÉROES JODER, seguro que tú también harías lo mismo y si crees que no puedes hacer nada QUÉDATE EN CASA y salvarás vidas como nosotros.

Ojalá, tras estos aplausos, salgan con nosotros a las calles para reivindicar lo necesaria que es la sanidad pública. Ojalá. Ojalá tras esto, esos aplausos mantengan la fuerza y las ganas de luchar.

\section{La soledad de la Zona Roja}

El primer día que atendí a una paciente con COVID pensé mucho en eso de sentirse solo al otro lado de la línea roja. Pero también pensé y sentí que esa sensación no era real, que se encontraban mis compañeros al otro lado y que estaban igual o más pendientes que normalmente. El runrún de mi cabeza iba un poco más allá. Yo tenía a mi compañera fuera, podía acercarme incluso a la puerta a gesticular o llamar a alguien, pero ¿y el paciente? Desde ese primer día y hasta ahora es lo que siento como más duro de esta nueva etapa, de esta pandemia desde la visión del enfermero: la soledad de los pacientes.

Ingresan sabiendo la gravedad de todo esto, ingresan solos, se separan de sus familiares y pertenencias nada más poner un pie en el hospital. Les ponemos una pulsera, les rodeamos de cables, hablamos de términos médicos a su alrededor, les acomodamos y les dejamos en una habitación aislada. Ellos sí están aislados. Aislados de quiénes son fuera de esas paredes, de sus familias, su casa, su vida... Y nosotros, como sanitarios, en condiciones normales tratábamos de permanecer a su lado, darles la mano, una sonrisa, un rato a su lado en silencio o escuchando... tanto al suyo como al de sus familias cuando venían a visitarles. Pero ahora no es posible. Las visitas están restringidas y los EPIs también. Por órdenes de los supervisores y por nuestra seguridad debemos tratar de reducir los tiempos de contacto, no exponernos "de más". Necesitan que sigamos sanos y trabajando. No tenemos material ni personal suficiente como para quedarnos al lado de esa persona aislada el tiempo que nos gustaría. Aun en esas condiciones, cada uno organiza su tiempo como puede $y$, aunque sea una vez por turno escasos minutos, aprovechamos al $2000 \%$. Yo pongo mano sobre mano a los pacientes a los que me acerco: mano, guante, bata, guante y mano, pero ahí estamos. Sonreímos por el hueco entre el gorro, las gafas, la máscara y la mascarilla; es una sonrisa de ojos, como yo les digo, pero ellos la entienden. Es complicado lidiar con ello, con las prisas, el riesgo, la falta de medicación, camas, personal, equipos de protección,... Llegar y hacerte con ese huequito de cercanía es complicado, pero desde mi punto de vista, desde mi humilde recién inaugurado recorrido profesional, de no hacerlo se me haría todo muchísimo más complicado. Es en esos ratos donde realmente me siento enfermera y necesaria en todo este caos.

Un día me llegó un mensaje, uno de los mil que se pasan ahora difundidos por Whatsapp, donde una médico de otro hospital de Madrid había puesto en marcha un correo electrónico para que familiares o personas totalmente ajenas a los pacientes, escribiesen cartas para entregárselas y hacerles menos dura esa soledad, esa angustia de no tener a alguien cerca. Sentí que ella entendía también mi frustración al no poder estar cerca "un ratito más" y me puse manos a la obra. Organicé un correo para el Hospital Puerta de Hierro "unidoscontraelcovid" y lo envié por el grupo de trabajo a familia y amigos. Les expliqué el porqué de ese correo, cómo me sentía, ese huequito de cuidados que creía fundamental y que no nos era posible dar. Ese mismo día recibí las primeras cartas y a partir de entonces son cientos ya. Las guardo en un Word, las maqueto y las imprimo en el hospital los días que llego temprano. Luego, cuando salgo de trabajar me paso por las salas y las reparto; dejo un montoncito en cada control de enfermería y les explico: "Son cartas para los pacientes, son de gente que no les conoce pero quieren hacerles menos duro todo esto y estar cerca cuando nosotros no podemos; hay muchísima gente aportando su granito desde fuera, seguro que son parte de los que aplauden" y antes de irme añado "imagino el lío que tendréis por aquí también, pero repartidlas como consideréis, a quien veáis que lo necesita más, que está más sólo, más triste, quien no tenga móvil porque se lo quedaron sus familiares, algún abuelillo que no se apañe con las tecnologías,... vosotros elegís y porfa, eso sí, poned el nombre del paciente en el sobre antes de dársela, que siempre hace ilusión recibir una carta dedicada y más en estos días... Gracias, ánimo y buen turno". Y siempre me devuelven sonrisas. Esas sonrisas de ojos que se ven detrás del caos, del cansancio, del miedo y de las mascarillas.

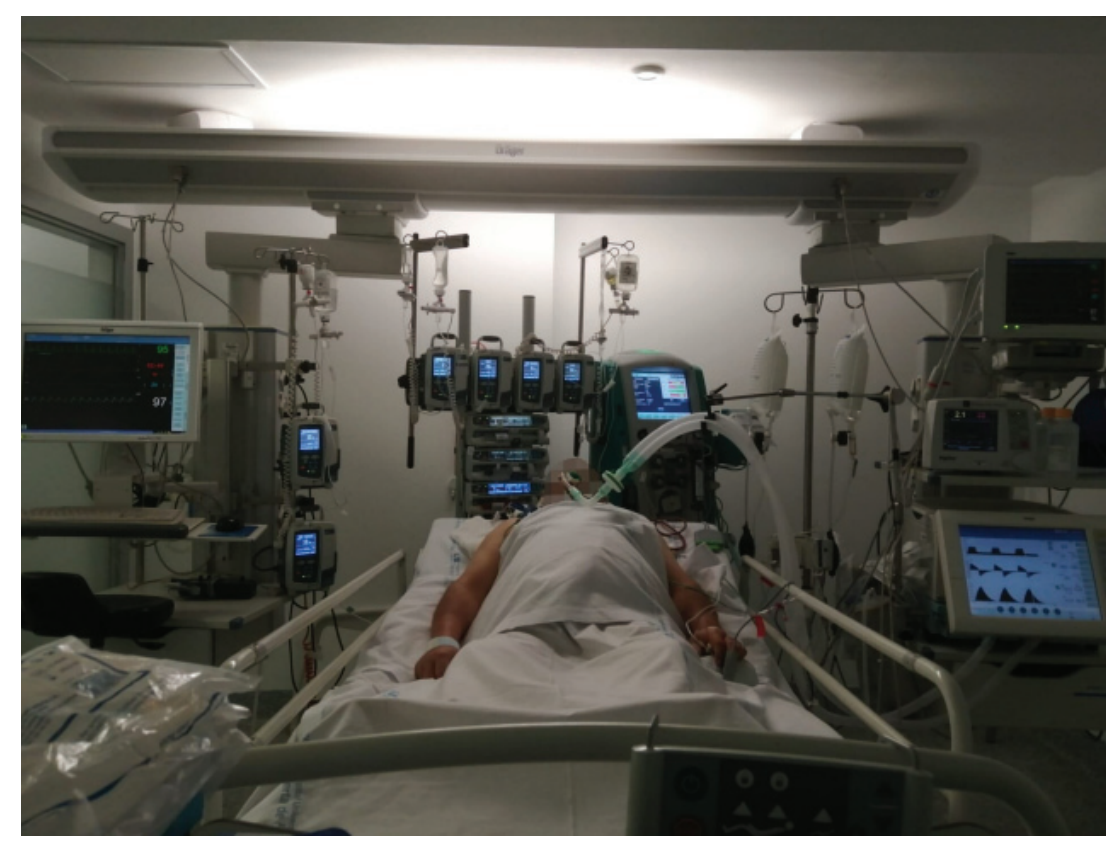

Soledad. Uno de los pacientes en nuestra UCI. Le rodean bombas de perfusiones, monitores, el respirador, un hemofiltro, vías, cables... Pero justo ahí, bajo esa mancha borrosa, está un padre, un esposo, un hijo y un farmacéutico que mucho temía contagiarse y enfermar a los suyos. Parece que su familia está sana, eso nos han dicho los médicos que hablaron con ellos tras el ingreso. Llegó hace dos días. Apretó muy fuerte mi mano mientras lo dormía profundamente, quién sabe hasta cuándo. Cuánto quisiera verlo despierto de nuevo. En espera, tengo en mi celular un video que su familia le ha grabado para que, ese día feliz, se lo pongamos al despertar. 
El otro día se lo escribí a mi madre en respuesta a su cuarta carta (respondo con un mensajillo anónimo a todos los que envían algo, creo que es lo menos que puedo hacer):

Mil gracias una noche más y tras una carta más. Todo esto da mucha mucha fuerza. A todos. Ahora mismo, con todo esto, estáis haciendo la parte más difícil de la enfermería: estar cerca y que te sientan cerca. Creo que sin eso tendría que darle la razón a los que proponen ese mundo futuro en el que a los enfermeros podrían sustituirnos por robots. La enfermera insustituible es la que da la mano, escucha un rato y está ahí con sonrisas, silencios, pañuelos o cartas. $Y$ son estás las únicas que llegan ahora. Vosotros, con vuestras cartas, día a día, hacéis de enfermeras un ratito y hacéis que, en parte, nos sintamos ahí, cerca, un rato nosotras también. Gracias a esto seguimos sintiéndonos lejos de los robots, cerca de los pacientes y de cada uno se vosotros :) Estáis hechos de otra pasta... Gracias de verdad y una vez más.

Un beso grande.

\section{Nueva forma de ver la profesión y la vida}

El cambio de forma de trabajo ha sido abismal. Comentamos mucho cómo se ha reforzado la unión entre las personas que formamos el equipo: médicos, celadores, auxiliares y enfermeras. Todos y entre todos hemos arrimado el hombro. Ojalá nos sirva para acordarnos del que tenemos al lado cuando esto acabe. Darnos cuenta y ver lo realmente indispensable que es el trabajo de todos y cada uno de nosotros y, más aún, de la fuerza que se saca al trabajar de forma conjunta y en equipo.

Desde el punto de vista de la enfermería, sólo decir que no cambiaría por nada esta profesión. Que muchos momentos son y serán duros, que quizá con los años se note más el peso, no lo sé. Solo sé que, hoy por hoy, no me puedo sentir más llena de ganas por seguir ahí cuidando a pie de cama: no puedo estar más orgullosa de haber elegido ser enfermera. Eso sí, espero pronto volver a la cercanía sin todas las barreras que hay ahora y nos impiden acercarnos como realmente nos gustaría a los pacientes y sus familias... que a veces, en estos días, me falta eso para sentirme realmente yo, para sentir que no soy robot, que sigo cuidando y "siendo enfermera".
En cuanto a la visión de la vida, no sé aún cómo cambiará o si habrá realmente cambios, porque siempre me he sentido afortunada. Pienso que tengo una familia increíble, que siempre están unidos (con o sin COVID de por medio) y que, a su forma cada uno, siempre estamos cuidándonos unos a otros. Pienso que no hay mejor compañía de cuarentena que un enfermero: él, enfermero y pareja, que por mucho que me resista me cuida y se deja cuidar, compartimos frustraciones, novedades, guardias y vida a fin de cuentas. Afortunada también por esa recua de amigos que mandan abrazos de ánimos eternos, vídeos absurdos para sacarme sonrisas o su gran "brindaremos en una terracita al sol cuando esto acabe".

Quizá también otra de las cosas que me han hecho pararme a pensar es esta sensación de ser el centro, ser más protagonista entre ellos de lo que me gustaría. Suena raro, pero creo que siempre me he sentido más cómoda desde bambalinas y sentir sus miradas en mí, por una parte, claro que se los agradezco, están pendientes y les entiendo, pero qué sensación de responsabilidad, de que no me puede pasar nada, no puedo fallarles, no puedo contagiarme y hacer que su preocupación se multiplique exponencialmente.

\section{Consejos a los trabajadores de la salud}

Como antes he dicho, suelo pasarlo bastante mal sintiéndome protagonista. Eso unido a la sensación de ser tan nueva en todo y con tanto por aprender como enfermera, me hace pensar que soy la menos indicada para dar consejos. Sólo puedo decir que piensen en el de al lado, que protegiéndole nos protegemos y que en equipo todo esta carga se va a llevar mejor. Eso, y preguntarse los porqués, escuchar, comparar, informarse e interesarse, ver un poco más allá de los dogmas del primero que los impone o de los protocolos del reducto de tu unidad. Durante la pandemia y más allá de ésta, en la enfermería, seguramente en cualquier profesión y en la vida: hacerse preguntas te mantiene despierto y en crecimiento.

Acabo todo este caos de letras y palabras con una frase que siempre me recordaba mi abuelo: "Todo pasa, lo bueno y lo malo". Pero ojalá, cuando pase, algo hayamos aprendido de todo esto. $-1 /$ -

Submitted: April 2020

Approved for publication: August 2020

Disclosures: None

Correspondence: p.guerrahoyos@gmail.com 


\section{MEDICC \\ Review}

\section{A Call for Papers}

\section{To Latin American \& Caribbean Health \& Related Professionals}

- MEDICC Review welcomes papers from Latin American and Caribbean authors, addressing today's critical interactions between human health, development of sustainable societies, and the health of our planet.

- In the era of the COVID-19 pandemic, MEDICC Review editors are fast-tracking peer review of papers that provide results of regional, national or local experiences with prevention, control, diagnosis, and therapies, as well as development of medications and vaccines. See Author Guidelines at www.mediccreview.org for Short Article, Lessons From the Field, and Original Research sections.

- Your evidence-, experience-based commentaries are also welcome for our Perspective and Viewpoint sections.

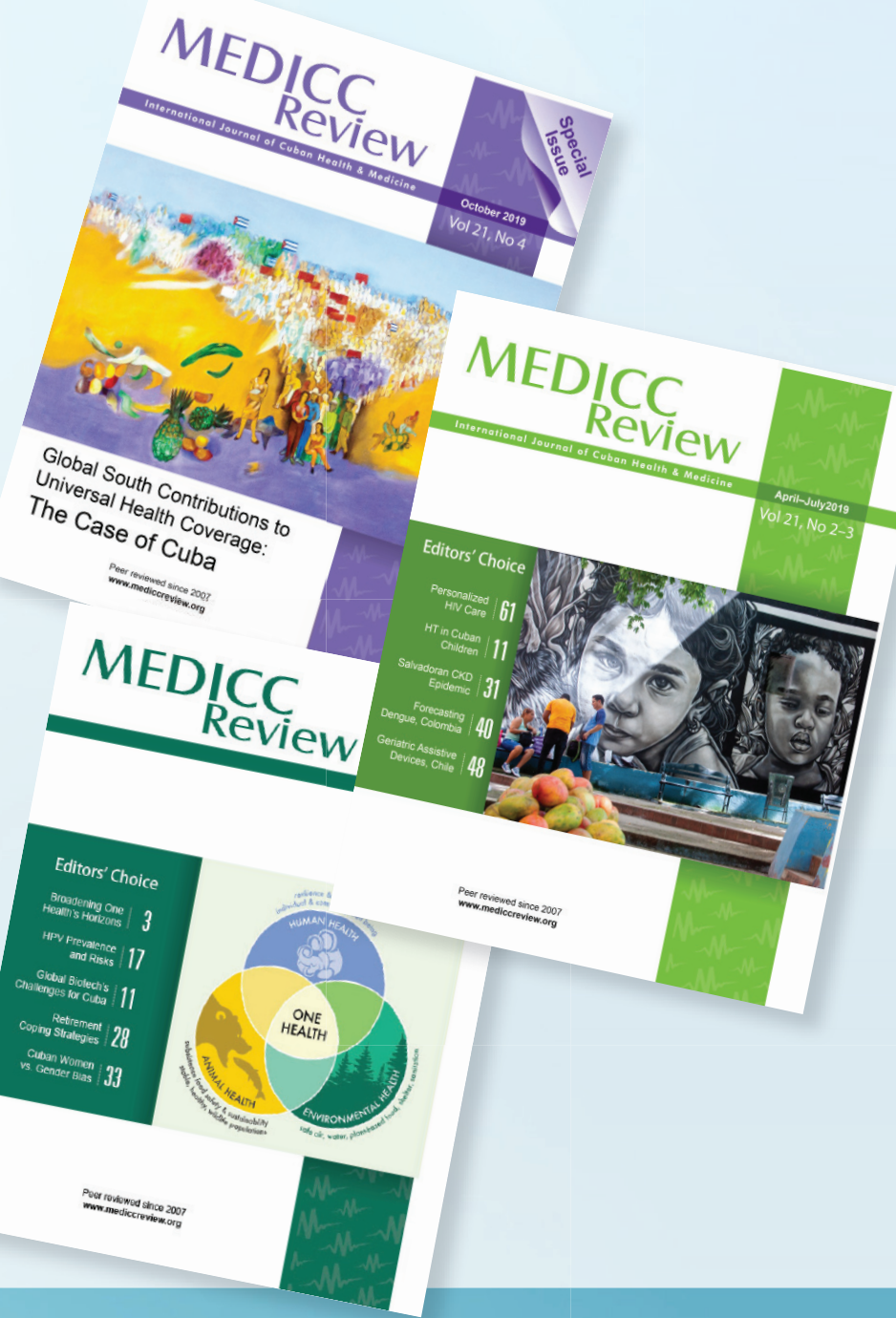

MEDICC Review is an open-access journal published by MEDICC, a non-profit organization based in Oakland, California, USA. The journal is indexed by PubMed, Clarivate Analytics, SciELO, Elsevier (Embase and SCOPUS), EBSCO, CABI Global Health, Redalyc, Latindex and Road.
We consider submissions in Spanish, English and Portuguese for publication in English. No author fees are charged. 


\section{COVID-19, Your Pet and Other Animals: Are You at Risk?}

\section{María Irian Percedo-Abreu DVM PhD}

Despite fast-tracked research, the precise origin, transmission and evolution of COVID-19 are still unknown. While the bat genus Rhinolophus is likely the primary source of the zoonotic-origin pathogen SARS-CoV-2 that causes COVID-19, its transmission route into the human population is still being studied.[1,2]

Coronaviruses (CoV) affect humans and various animal species. Bats were the original hosts of the CoV that causes Severe Acute Respiratory Syndrome (SARS-CoV) and Middle East Respiratory Syndrome coronavirus (MERS-CoV), for example, with masked palm civet cats and dromedaries, respectively, the intermediate hosts of those two viruses. Research is ongoing regarding intermediate species for SARS-CoV-2, but one possibility is the large stray cat and dog population around the live animal market in Wuhan, China, where the pandemic is thought to have started.

Explaining the epidemiological role of different species in COVID-19 transmission is fundamental for its prevention and control, since identifying possible viral reservoirs can limit future, unexpected outbreaks. For example, MERS control included a proposal for vaccinating dromedaries;[3] surveillance of SARS-CoV-2 in undomesticated cats and dogs can serve a similar purpose.[4,5]

After asymptomatic dogs were infected with SARS-CoV-2 following close contact with their infected owners in Hong Kong in March, 2020, the World Organization for Animal Health (OIE) began requiring notification of domestic animals infected with SARS-CoV-2. An ad hoc group of international experts was convened to analyze reports and undertake research to better understand the epidemiological significance for animal health, biodiversity and public health.[1]

In experimental studies, pigs and poultry did not become infected with SARS-CoV-2, but ferrets and cats did; dogs were less susceptible. In silico models suggest other mammals that might become infected like humans include chimpanzees, monkeys and bovines, given the similarity in angiotensin-converting enzyme 2 (ACE2) receptors, with high affinity for the spike (S) glycoprotein.[4]

Cats, especially, require close surveillance given how efficiently the SARS-CoV-2 virus multiplies in experimental inoculations. Even asymptomatic cats transmitted the virus to other cats via aerosol a few days after being exposed. Outdoor cats from homes where COVID-19 is present may transmit the disease, as well as those having contact with potentially contaminated wastewater from affected communities.

There have been numerous reports of cats naturally infected in several European countries, Hong Kong, Russia and the United States, following close contact with their sick owners. Active surveillance of 102 cats in Wuhan during the epidemic revealed 15 $(14.7 \%)$ were seropositive for SARS-CoV-2. The highest titers were found in 3 cats whose owners were confirmed with COVID-19; of the remaining 12, 6 came from a pet shelter and the other 6 were street cats.[6] Symptomatic lions and tigers that tested positive for COVID-19 at the Bronx Zoo in New York is another indication of feline susceptibility.
A study of 817 pets (540 dogs, 277 cats) in Italy when the country was experiencing high rates of the epidemic, revealed none tested positive for COVID-19 using real-time polymerase chain reaction (RT-PCR). However, 3.4\% dogs and 3.9\% cats showed a prevalence of SARS-CoV-2-neutralizing antibody titers-similar to rates in the human population-with a higher probability for those dogs from homes with owners testing positive for COVID-19.[7]

Meanwhile, dozens of mink farms in the Netherlands, Denmark and Spain and two in the USA have been infected with SARSCoV-2. Clinical signs varied in the Netherlands, where thousands of mink were sacrificed and reverse zoonosis (human to mink) of SARS-CoV-2, with further transmission from farmworkers to people in their homes, was documented. Stray cats and dogs in the vicinity of the infected farms also tested positive. A total mink farm ban goes into effect in that country in early 2021 to avoid potential viral reservoirs.

Farm animals have greater
potential to become viral
reservoirs due to
industrial-scale farming
practices

Susceptibility to SARSCoV-2 in rabbits is another concern. Farm animals have greater potential to become viral reservoirs due to industrial-scale farming practices with large numbers of animals in continual production. Such conditions lend themselves to longer outbreaks with higher viral loads, since newborns are more prone to infection and facilitate transmission. Furthermore, asymptomatic animals contribute to low risk perception. Strict controls and prohibiting access to symptomatic workers are fundamental for preventing infections among farm animals.[8]

More research around this issue is needed, including larger-scale studies in different contexts, with animals from infected and noninfected homes and in areas with local transmission. To bridge this research gap, the OIE and the Food and Agriculture Organization (FAO) recommend public and animal health authorities undertake intersectoral risk analysis with a One Health approach. Meanwhile, international organizations suggest people testing positive for COVID-19 take precautions around animals, including isolating pets and other animals to avoid infection, while observing general hygiene measures with companion animals, in live animal markets and markets with animal products. $[1,2,8]$

In my opinion, the scientific community has sufficient evidence to support the hypothesis that animals are a potential link in the epidemiologic chain of human-human COVID-19 infection. Taking into account epidemiological antecedents and principles on the variability of disease processes in individuals and populations, depending on factors including the pathogens, hosts and environment, I consider the following steps necessary: 1) epidemiological studies of homes where COVID-19 is present should include variables related to pet and other animal ownership-number and type of pets/other animals in the home, their health status, human-animal relationship, where pets would go if the owner is hospitalized and 2) virology and/or serology tests for pets to detect SARS-CoV-2 infection. In resource-scarce settings, a case-con- 
trol study can be conducted, with protocols set by public health and veterinary services.

In Cuba, there are qualified veterinary medicine specialists to conduct this type of research; protocols to this effect proposed by the Animal Health Department, Ministry of Agriculture and the National Center for Agricultural Animal Health (CENSA) are currently being analyzed.
Many people maintain very close relationships with their pets, sometimes cohabitating with many animals (especially older people who live alone), while children enjoy playing with pets. Disseminating information about COVID-19 and animals will help promote recommended preventive measures. It's not about abandoning our pets, but rather taking all the necessary precautions to control the COVID-19 pandemic. $-1 /$ -

\section{REFERENCES}

1. OIE-World Organisation for Animal Health [Internet]. Paris: OIE-World Organisation for Animal Health; OIE 2020. Portal sobre COVID-19. Preguntas y respuestas sobre COVID-19; [updated 2020 Jun 9; cited 2020 Aug 20]. Available at: https://www.oie.int/es/nuestra-experiencia-cientifica/ informaciones específicas y recomendaciones/preguntas y respuestas del Covid-19/. Spanish.

2. Pan American Health Organization. Nota Informativa. Infecciones por SARSCoV-2 en animales [Internet]. Washington, D.C.: Pan American Health Organization; 2020 Jul 21 [cited 2020 Aug 20]. 5 p. Available at: http://docs.bvsalud .org/biblioref/2020/07/1103787/download.pdf. Spanish.

3. Hemida MG. Middle East Respiratory Syndrome Coronavirus and the One Health concept. PeerJ [Internet]. 2020 Aug 22 [cited 2020 Aug 24];7:e7556. Available at: http://doi.org/10.7717/peerj.7556

4. Shen M, Liu C, Xu R, Ruan Z, Zhao S, Zhang H, et al. SARS-CoV-2 infection of cats and dogs? Preprints [Internet]. Basel: MDPI; 2020 [cited 2020 Aug 20]. Available at: https://www.preprints.org/manuscript/202004.0116/v1

5. Xia X. Extreme genomic CpG deficiency in SARS-CoV-2 and evasion of host antiviral defense. Mol Biol Evol [Internet]. 2020 Apr 17 [cited 2020 Aug 20]. Epub ahead of print. Available at: https://academic.oup.com/mbe/article/ doi/10.1093/molbev/msaa094/58195
6. Zhang Q, Zhang H, Huang K, Yang Y, Hui X, Gao J, et al.. SARS-CoV-2 neutralizing serum antibodies in cats: a serological investigation. bioRxiv [Internet]. New York: Cold Spring Harbor Laboratory; 2020 Apr 3 [cited 2020 Apr 11]. Available at: https://doi.org/10.1101/2020.04.01.021196

7. Patterson EI, Elia G, Grassi A, Giordano A, Desario C, Medardo M, et al. Evidence of exposure to SARS-CoV-2 in cats and dogs from households in Italy. bioRxiv [Internet]. New York: Cold Spring Harbor Laboratory; 2020 Jul 23 [cited 2020 Aug 20]. Available at: https://www.biorxiv.org/content/10.1101/2020.07.2 1.214346v2.full.pdf

8. Food and Agriculture Organization of the United Nations (FAO). Guidelines to mitigate the impact of the COVID-19 pandemic on livestock production and animal health [Internet]. Rome: Food and Agriculture Organization of the United Nations (FAO); 2020 [cited 2020 Aug 30]. 19 p. Available at: http://www.fao .org/3/ca9177en/CA9177EN.pdf

Submitted: August 31, 2020

Approved for publication: September 11, 2020

Disclosures: None

Correspondence: percedo@censa.edu.cu, mipercedo@infomed.sld.cu 


\title{
Not Infected but Physically and Mentally Affected: Older Cubans and COVID-19
}

\author{
Jesús E. Menéndez-Jiménez
}

COVID-19 has dominated the conversation this year. Following the first outbreaks in December 2019, it became clear that older adults were predisposed to greater disease severity and death. What occurred in nursing homes across Europe and the Americas was brutal-as much for the older adults themselves as for their families. Many didn't even get to say goodbye.

When the first COVID-19 cases were diagnosed in Cuba in March of this year, I feared for our older adults living in nursing homes. We have 155 nursing homes where 12,368 people live full time, plus 3481 part-time live-ins across the country. Additionally, over 10,000 older adults participate in daily activities at our national network of 295 Senior Centers. $[1,2]$ But by May, there had been just a single outbreak in a nursing home-in Santa Clara city in central Cuba. We got lucky, I thought. After weeks and then months, I realized it wasn't luck, but rather the result of political will, well-designed and implemented protocols and trained health professionals and others dedicated to doing a good job. This was what kept COVID-19 incidence low in our nursing homes.

But COVID-19 isn't just an infectious disease: it impacts people's lives in other ways. In spite of the resilience Cubans have shown in the face of natural disasters and extreme economic circumstances, we are beginning to see the effects-which will continue over timein the population's physical and mental health, especially among the most vulnerable, including older adults.

Prolonged confinement due to lockdown can trigger changes in personal and social relations in a short time, adversely affecting people's mental health. This was less visible at the outset of the pandemic since the priority was saving lives.[3]

Although efforts have been

Prolonged confinement due to lockdown can trigger changes in personal and social relations in a short time, adversely affecting mental health
Moreover, prolonged lack of physical activity can have negative effects that are even harder to overcome later on, such as losing the exercise habit, overweight, pain, falls and fear of falling, among others. Health prevention measures that restrict movement outdoors can also mean that older adults lose autonomy and their social interactions shrink considerably.

According to Dr Francisco Durán, Cuba's National Director of Epidemiology, most deaths between January 1 and April 30, 2020 were due to chronic disease, not COVID-19-38,300 as compared to 64.[7] Cuba has paid close attention to chronic disease as a risk factor for developing severe COVID-19 and prioritized people with cardiovascular or respiratory disease, diabetes, cancer and other chronic conditions. Furthermore, cancer and other chronic disease treatments have been maintained throughout the pandemic.

Less analysis, however, has been conducted around older adults who don't contract COVID-19 and the possible impact of lockdowns on their mental and physical health.

Knowing that overweight, anxiety and low levels of physical activity during lockdown can increase risk for cardiovascular and cerebrovascular disease begs the question: what are we doing about it?

Since April 2020, community-based networks involving public, private and cooperative sector workers have been established to support the most vulnerable, with emphasis on older adults who live alone. Meanwhile, health institutions like Community Mental Health Centers, located in each municipality throughout the country, offer free mental health services. And specialized web pages have been created to provide resources and recommendations to mental health professionals for treating their patients during the pandemic.[8]

Cuban civil society is actively providing support as well. For example, the Cuban Psychological Society launched a unique initiative called 'Psico Grupos' that provides psychological consultations using the WhatsApp platform. The Cuban Geriatrics and Gerontology Society, as part of the PIESPLAZA Project (an initiative co-financed by Cuba and the European Union), provides support to caretakers of older adults in the Plaza de la Revolución municipality of Havana by distributing educational pamphlets detailing how care can be improved for this vulnerable group during the pandemic. These actions make a positive contribution to the mental health of older adults.

In my experience as a geriatrician, I think exercise and physical activity are the best medicine for staving off many physical and psychological health problems-no matter what your age, but especially in older adults. Exercising, even at home, improves mobility, leads to fewer falls and increases 


\section{Viewpoint}

well-being. Given these multiple benefits, I recommend exercise for older adults and counsel families to encourage their older adults to embrace exercise and physical activity during lockdown.

This is also a time to motivate older adults towards self-care to help ameliorate chronic disease complications, promoting steps they can take to assume responsibility for their own well-being. Healthier eating habits, some form of physical activity at home (or in safe places when it's permitted), proper dental hygiene and getting a good night's sleep can all have positive effects.
We need a 'new normal' that incorporates or re-incorporates healthy lifestyles, especially among older adults. Those who attend to the needs of older adults, whether in the health

\section{We need a 'new normal' that incorporates or re- incorporates healthy lifestyles, especially among older adults} sector or the community, have an important role to play in helping them regain their health and positive outlook on life. Even if they never became infected, COVID-19 can have lingering effects-for older adults and in fact, for all of us. - wh

\section{REFERENCES}

1. National Health Statistics and Medical Records Division (CU). Anuario Estadístico de Salud 2019 [Internet]. Havana: Ministry of Public Health (CU); 2020 [cited 2020 Sep 30]. 206 p. Available at: https://files.sld.cu/bvscuba/ files/2020/05/Anuario-Electrónico-Español-2019-ed-2020.pdf. Spanish.

2. Data from Ministry of Public Health (CU). Personal communication. December 2019

3. Ribot Reyes VC, Chang Paredes N, González Castillo AL. Efectos de la COVID-19 en la salud mental de la población. Rev Haban Ciencias Méd [Internet]. 2020 [cited 2020 Aug 31];19(Suppl.):e3307. Available at: http://www.revhaba nera.sld.cu/index.php/rhab/article/view/3307. Spanish.

4. Ayers JW, Leas EC, Johnson DC, PoliakA, Althouse BM, Dredze M, et al. Internet Searches for Acute Anxiety During the Early Stages of the COVID-19 Pandemic. JAMA Intern Med [Internet]. 2020 Aug 24 [cited 2020 Aug 31]. Available at: https://jamanetwork.com/journals/jamainternalmedicine/fullarticle/2769543

5. Encuesta Nacional de Envejecimiento Poblacional 2017 (ENEP 2017) [Internet]. Havana: National Statistics Bureau (CU), Center for Population and Development Studies; 2019 Sep [cited 2020 Sep 18]. 238 p. Available at: http://www .onei.gob.cu/sites/default/files/0.enep-2017_documento_completo.pdf. Spanish.

6. Xue QL. The Fraility Syndrome: Definition and Natural History [Internet]. Clin Geriatr Med. 2011 Feb [cited 2020 Sep 22];27(1):1-15. Available at: https:// www.ncbi.nlm.nih.gov/pmc/articles/PMC3028599/

7. Enfermedades no transmisibles aportan mayor cifra de decesos en Cuba [Internet]. Havana: Prensa Latina; 2020 May 17 [cited 2020 Aug 31]. Available at: https://www.prensa-latina.cu/index.php?o=rn\&id=366727\&SEO=enfermed ades-no-transmisibles-aportan-mayor-cifra-de-decesos-en-cuba. Spanish.

8. INFOMED [Internet]. Havana: Ministry of Public Health (CU); c2020. Especialidades. Psiquiatría. Recomendaciones para los profesionales de la salud mental en el contexto de la COVID-19 en Cuba; [cited 2020 Aug 31]. Available at: https://especialidades.sld.cu/psiquiatria/2020/06/06/recomendaciones-para -los-profesionales-de-la-salud-mental-en-el-contexto-de-la-covid-19-en-cu ba-2/. Spanish.

Submitted: September 8, 2020

Approved for publication: September 26, 2020

Disclosures: None

Correspondence: jmj@infomed.sld.cu 


\section{Silent or 'Happy' Hypoxemia: An Urgent Dilemma for COVID-19 Patient Care}

\author{
Calixto Machado-Curbelo MD, PhD, FAAN
}

A perplexing clinical aspect of COVID-19 is presentation of patients with pronounced hypoxemia without expected signs of respiratory distress or dyspnea, even when cyanotic. Nonetheless, these patients frequently leapfrog clinical evolution stages and suffer acute respiratory distress syndrome (ARDS), with concomitant cardiorespiratory arrest and death.[1] This phenomenon is referred to as silent or 'happy' hypoxemia.[2-5]

Silent hypoxemia Analysis of a Wuhan, China cohort of patients with serious SARS-CoV-2 infections revealed that only $19 \%$ complained of shortness of breath,

\section{In spite of low blood oxygen levels, some patients seem to be functioning without serious issues or even shortness of breath}

while $62 \%$ of them, as well as $46 \%$ of those whose clinical progression ended in either ventilation or death, also exhibited no dyspnea.[1] In spite of low blood oxygen levels, some patients seem to be functioning without serious issues or even shortness of breath. Such serious or 'happy' hypoxemia is characterized by a significantly increased respiratory rate, as high as 38 breaths/min and deep hypoxia with low partial pressure of dissolved carbon dioxide in blood $\left(\mathrm{PaCO}_{2}\right)$ and no concurrent dyspnea.[2,3]

Dyspnea pathophysiology Our interoceptive sensorial system receives the homeostatic afferent information sensing the body's physiological condition, creates awareness, and leads to conscious feelings or symptoms. That sensory information arrives at the central nervous system, and then projections from the brainstem to the cortex allow the brain to process homeostatic afferent signals. When the brain receives the signal of internal hypoxia, it gives rise to the sensation of 'air hunger' and urge to breathe, which is curiously absent in some severe COVID-19 patients. Dyspnea is a subjective symptom reported by patients and should not be confused with rapid breathing (tachypnea), excessive breathing (hyperpnea), or hyperventilation.[3]

Dyspnea: $\mathrm{PaO}_{2}$ vs. $\mathrm{PaCO}_{2}$ Hypoxemia, low partial gas pressure of dissolved oxygen $\left(\mathrm{PaO}_{2}\right)$, plays a rather limited role in the breathlessness experienced by patients with cardiopulmonary disease, contrary to the hypercapnia that generates dyspnea. Change in $\mathrm{PaCO}_{2}$ is the most significant component contributing to dyspnea, triggering shifts in $\mathrm{pH}$ levels in both the peripheral and central chemoreceptors. Severe hypoxia elicits an effective increase in ventilation only when background $\mathrm{PaCO}_{2}$ surpasses $39 \mathrm{mmHg} \cdot[2,3]$

Pathophysiology of silent hypoxemia One pathophysiological explanation for severe hypoxemia in lungs still exhibiting a degree of compliance is impaired regulation of pulmonary blood flow and loss of hypoxic pulmonary vasoconstriction. A recent report suggests SARS-CoV-2-mediated mitochondrial damage in the pulmonary artery smooth muscle cells

may explain the impairment of hypoxic pulmonary vasoconstriction. The carotid bodies' reduced ability to sense oxygen due to mitochondrial injury has been mentioned as a possible explanation for the limiting of the respiratory drive and for reduced dyspnea.[3]

Changes in oxyhemoglobin dissociation curve Pulse oximetry, which measures oxygen saturation $\left(\mathrm{SpO}_{2}\right)$, is often used to detect hypoxemia. Nevertheless, $\mathrm{SpO}_{2}$ should be interpreted carefully in the context of COVID-19. The sigmoid-shaped oxyhemoglobin dissociation curve shifts to the left due to induced respiratory alkalosis (drop in $\mathrm{PaCO}_{2}$ ) attributable to hypoxemia-driven tachypnea and hyperpnea. During hypocapnic periods, the affinity of hemoglobin for oxygen, and thus $\mathrm{SpO}_{2}$, rises for a specified degree of $\mathrm{PaO}_{2}$, explaining why $\mathrm{SpO}_{2}$ can be well preserved in the face of a profoundly low $\mathrm{PaO}_{2}$. Thus, physicians should not only rely on patients' self-reporting of distress, but closely monitor respiratory rates, signs of hyperventilation, oxygen saturation and, if necessary, perform invasive measurements for hypoxemia/hypocapnia at regular intervals.[2,3]

\section{Possible damage to the afferent hypoxia-sensing neurons in persons with COVID-19 could be due to the intense cytokine storm or the direct effect of SARS-COV-2}

Neural hypothesis for silent hypoxemia Such patients are often tachycardic with tachypnea and respiratory alkalosis. However, they are not aware of hypoxia. The possible damage to the afferent hypoxiasensing neurons in persons with COVID-19 could be due to the intense cytokine storm or the direct effect of SARS-CoV-2 on either mitochondria or nerve fibers. Hypoxia activates the carotid body chemoreceptors, and the afferent signals are relayed at the nucleus tractus solitarius located in the brainstem via the glossopharyngeal nerve. $[2,4,5]$

The nucleus tractus solitarius communicates with, among other regions, the reticular formation, parasympathetic preganglionic neurons, hypothalamus and thalamus, forming circuits that contribute to autonomic regulation.[2,3] The virus can enter through the nasal or oral cavity and may spread along the axons of cranial nerves V, VII, IX and $X$. SARS-CoV-2 can therefore cause inflammation of the nucleus tractus solitarius through the axonal and synapsis routes.[2,4]

Hence, in SARS-CoV-2-mediated inflammation of nucleus tractus solitarius, the afferent hypoxia stimuli from the carotid bodies may not be effectively relayed at the nucleus tractus solitarius, resulting in impaired efferent respiratory response. This may be the reason for the COVID-19 clinical presentation of almost normal breathing despite severe hypoxemia.[1-5] 
From silent hypoxemia to ARDS Silent hypoxemia may disguise severity of clinical status in COVID-19 patients, and ultimately delay their seeking medical care. Patients admitted with COVID-19 may die without ever expressing the need for supplemental oxygen. Such hypoxemia can lead to the erroneous conclusion that patients are not in serious or critical condition, with the concomitant danger that they may quickly jump clinical evolution stages and develop ARDS, resulting in cardiorespiratory arrest and death.[1,2]

It is urgent that the medical community be alert to silent hypoxemia in COVID-19, to assist physicians in their attempts to reduce the risk of sudden medical complications and death. -1 -

\section{REFERENCES}

1. Machado-Curbelo C. Severe Covid-19 cases: Is respiratory distress partially explained by central nervous system involvement? MEDICC Rev [Internet] 2020 Apr [cited 2020 May 15];22(2):38-41. Available at: https://mediccreview .org/severe-covid-19-cases-is-respiratory-distress-partially-explained-by-cen tral-nervous-system-involvement/

2. Anoop UR, Verma K. Happy hypoxemia in COVID-19. A neural hypothesis. ACS Chem Neurosci. 2020 Jul 1;11(13):1865-7.

3. Dhont S, Derom E, Van Braeckel E, Depuydt P, Lambrecht BN. The pathophysiology of "happy" hypoxemia in COVID-19. Respir Res. 2020 Jul 28;21(1):198.

4. Tobin MJ, Laghi F, Jubran A. Why COVID-19 silent hypoxemia is baffling to physicians. Am J Respir Crit Care Med. 2020 Aug 1;202(3):356-60.

5. González-Duarte A, Norcliffe-Kaufmann L. Is "happy hypoxia”' in COVID-19 a disorder of autonomic interoception? A hypothesis. Clin Auton Res. 2020 Aug;30(4):331-3

Submitted: September 8, 2020

Approved for publication: September 29, 2020

Disclosures: None

Correspondence: braind@infomed.sld.cu 


\title{
COVID-19 and the Kidneys: Risk, Damage and Sequelae
}

\author{
Raúl Herrera-Valdés MD MS PhD DSc, Miguel Almaguer-López MD MS, Laura López-Marín MD MS, Raymed Bacallao-Méndez MD MS, \\ Jorge F. Pérez-Oliva MD MS PhD, Guillermo Guerra-Bustillo MD MS
}

At first, COVID-19 was thought to be primarily a respiratory disease, progressing in some patients to serious respiratory symptoms, pneumonia, severe respiratory distress syndrome and even death. Later analysis revealed entire systems were compromised, affecting other vital organs, including the kidneys, and a correlation was observed between chronic kidney disease (CKD) and COVID-19 severity.[1,2]

This correlation can be broken down into three underlying circumstances: 1) CKD as a risk factor for infection, particularly in patients with end-stage renal disease (ESRD) who are either in dialysis or have received a transplant; 2) persons in the active stages of SARS-CoV-2 infection whose healthy kidneys develop lesions, including acute kidney injury (AKI); and 3) the possibility of medium- and long-term renal sequelae.

Conditions such as hypertension, cardiovascular disease, diabetes, advanced age, chronic obstructive pulmonary disease, obesity and CKD are associated with greater risk of COVID-19 and more severe infection. All these factors are often present in persons with CKD: for starters, diabetes and hypertension are the main drivers of CKD, and then the rest of the conditions are habitual comorbidities. Convergence of these factors not only increases risk, but their synergy facilitates chronic inflammation and the ensuing cytokine buildup. In advanced CKD, other comorbidities crop up, such as anemia, malnutrition, vitamin $D$ deficiency, immunodepression and the effects of immunosuppressors that accompany autoimmune diseases or renal transplant therapies.

In 2019, 4.37 million patients were receiving renal replacement therapies (RRT) worldwide. For hemodialysis patients, this implies the challenge of guaranteeing their frequent transportation to closed facilities with specialized personnel and equipment. For those with COVID-19, it has also meant setting aside dialysis units, patient circuit kits, medicines and staff to be deployed in isolation areas, given the attendant high risk to other RRT patients. Additionally, as health systems become saturated with the pandemic, transplants are postponed with few exceptions (such as combined organ transplants, emergency life-and-death situations, or when there is an optimal kidney available for a patient with few other options).[3]

Kidney damage is frequent during the active stage of COVID-19. A meta-analysis in China involving 4375 patients revealed high relative rates of proteinuria (42.0\%), hematuria (30.3\%) and AKI $(7.7 \%)$, as well as elevated creatinine (6.6\%) and urea (6.2\%). [4] Also in China, higher mortality was reported for COVID-19 patients with renal damage $(11.2 \% ; 28 / 251)$ than for those without (1.2\%; 1/82).[5] A prospective study of 1603 patients in Spain obtained similar results.[6] A US study of 5449 COVID-19 patients revealed hematuria and proteinuria in 46\%, AKI in 37\%, and dialysis required for 15\%.[7] Over $40 \%$ of ICU patients required $\mathrm{RRT}$.

In China, post-mortem studies confirmed lesions in the proximal tubules of the kidneys: loss of the brush border, vacuolar degen- eration, lumen dilation with associated buildup of cellular debris, denudation of the epithelium, erythrocyte aggregation, severe acute tubular necrosis, and interstitial lymphocyte infiltration. Additionally, they observed obstruction of the glomular and peritubular capillaries, and thrombi composed of aggregated platelets and fibrin.[8] Immunohistochemical analysis of the tubules showed an increase in the receptor for angiotensin converting enzyme 2 (ACE2) as well as antibodies against the nucleoprotein of SARS-CoV-2. Viral invasion was also detected elsewhere in kidney tissue. Electron microscopy and tests with anti-SARSCoV-2 antibodies show the direct cytopathic effects of viral replication in kidney tubular cells and in podocytes.[9]

Symptomatic COVID-19 patients exhibit a cytokine buildup and decreased $T$ lymphocytes. The most severe cases present with a 'cytokine storm'-interleukin-6, IL-6; interleukin-2 receptor, IL-2R; interleukin-10, IL-10; and tumor necrosis factor alpha,TNF- $\alpha$-as well as decreased interferon gamma (IFN- $\gamma$ ), which are associated with lung damage and respiratory distress. All these are conducive to kidney injury and imply a poor prognosis.[10]

The marked expression of ACE2 receptors in podocytes and proximal tubules suggests that the kidney may be an important target organ for SARS-CoV-2, because the virus invades cells by binding to such ACE2 receptors, subsequently inducing a decrease in the ACE2 enzyme. ACE2 belongs to the reninangiotensin-aldosterone system (RAAS). Angiotensin II (Ang II) is one of the main mediators of damage in kidney diseases, and the activation of RAAS has a strong influence on kidney disease progression. This system maintains a functional balance between ACE and ACE2; the first promoting the formation of Ang II, with vasoconstrictive, mitotic, inflammatory and fibrotic effects.

The main function of ACE2 is catabolism of Ang II to produce angiotensin 1-7. Angiotensin 1-7 reduces vasoconstriction, salt retention, oxidative stress and cell proliferation as a consequence of increased nitrous oxide and prostaglandins. The decrease in ACE2 promotes accumulation of Ang II by reducing its degradation to angiotensin 1-7, resulting in an imbalance of RAAS components with accumulation of Ang II. Decreased ACE2 and increased ACE indicate response to kidney damage progression. $[11,12]$

In terms of COVID-19 pathophysiology, WHO and PAHO have confirmed that the disease generates an inflammatory response that primarily affects the lungs, provoking sequelae in the cardiovascular, central nervous and peripheral nervous systems, as well as psychiatric and psychological sequelae.[13] Nevertheless, they have not mentioned renal sequelae.

Here, we return to the ACE2 receptor, since it plays a role in the mechanism by which SARS-CoV-2 damages the respiratory tract as its primary target, possibly propagating via the bloodstream to damage cells of other organs. Kidneys are the body's most vascularized organs, with 180 liters of blood circulating through them daily, and are one of the organs with greater ACE2 content, along 


\section{Viewpoint}

with the small intestine, testicles and heart. Thus, they are at high risk when it comes to COVID-19.[14]

In addition to the virus's cytopathic effects, a number of other factors can contribute to renal lesions, including hemodynamic changes, cytokine liberation, coagulatory disorders, sepsis, systemic hypoxia, drug-related toxicity and rhabdomyelosysis.[15]

Medium- and long-term COVID-19 impact on the kidneys is unclear, as is whether surviving patients with AKI can recover full renal function. What is clear is that the kidneys are involved in COVID-19 infection and AKI is an independent predictor of mortality.[16]

It is probable that kidney lesions acquired during the disease's active remain as sequelae that may result in a slow and asymp- tomatic progression towards advanced stages and CKD. Thus, patients who have recovered from COVID-19 who presented proteinuria, hematuria, elevated creatinine and AKI should be monitored for CKD.

By 2017, over 850 million people were estimated to suffer from various stages of CKD and ARD worldwide, twice the number of diabetics and 20 times more than those with HIVIAIDS. Given the high numbers of COVID-19 cases globally, we foresee the possibility of millions more people who may require dialysis or transplant. But, is the world and its health systems-stretched to the limit as they are-prepared to face a chronic kidney disease pandemic superimposed or following the coronavirus pandemic? Not yet, certainly. And we can hardly afford to ignore the warnings of such an eventuality: we have already seen where that can lead, and too many have already paid the price with their lives. $-1 /$ -

\section{REFERENCES}

1. Yang $X, Y u Y, X u J$, Shu $H$, Xia J, Liu H, et al. Clinical course and outcomes of critically ill patients with SARS-CoV-2 pneumonia in Wuhan, China: a single-centered, retrospective, observational study. Lancet Respir Med. 2020 May;8(5):475-81.

2. Wang X, Fang X, Cai Z, Wu X, Gao X, Min J, et al. Comorbid chronic diseases and acute organ injuries are strongly correlated with disease severity and mortality among COVID-19 patients: a systemic review and meta-analysis. Research [Internet]. 2020 [cited 2020 Aug 10];2020: Article ID 2402961.,17 p. Available at: https://doi .org/10.34133/2020/2402961

3. Parson JA, Martin DE. A call for dialysis-specific resource allocation guidelines during COVID-19. Am J Bioethics. 2020 Jul 27 [cited 2020 Aug 10];20(7):199-201. Available at: https://doi.org/1 0.1080/15265161.2020.1777346

4. Yang $\mathrm{Q}$, Yang $\mathrm{X}$. Incidence and risk factors of kidney impairment on patients with COVID-19: a systematic review and meta-analysis. medRxiv [Internet]. New York: Cold Spring Harbor Laboratory; 2020 Jun 3 [cited 2020 Aug 11]. Available at: https://doi.org/10.1101/2020.05.28.20116400

5. Pei G, Zhang Z, Peng J, Liu L, Zhang C, Yu C, et al. Renal involvement and early prognosis in patients with COVID-19 pneumonia. JASN [Internet]. 2020 Jun [cited 2020 Aug 11];31(6):1157-65. Available at: https://doi.org/10.1681/ASN.2020 030276

6. Portolés J, Marques M, López-Sánchez P, Valdenuevo M, Muñez E, Serrano ML, et al. Chronic kidney disease and acute kidney injury in the COVID-19 Spanish outbreak. Nephrol
Dial Transplant. 2020 Sep 2 [cited 2020 Sep 4];35(8):1353-61. Available at: https://doi .org/10.1093/ndt/gfaa189

7. Hirsch JS, Ng JH, Ross DDW, Sharma P, Shah $\mathrm{HH}$, Barnett $\mathrm{RL}$, et al. Acute kidney injury in patients hospitalized with COVID-19. Kidney Int. 2020 Jul [cited 2020 Aug 11];98(1):209-18. Available at: https://doi.org/10.1016/j.kint.2020.05.006

8. Su H, Yang M, Wan C, Yi L, Fang Tang F, Zhu $\mathrm{H}$, et al. Renal histopathological analysis of 26 postmortem findings of patients with COVID-19 in China. Kidney Int. 2020 Jul 1 [cited 2020 Aug 11];98(1):219-27. Available at: https://doi .org/10.1016/j.kint.2020.04.003

9. Farkash EA, Wilson AM, Jentzen JM. Ultrastructural evidence for direct renal infection with SARS-CoV-2. JASN [Internet]. 2020 Aug [cited 2020 Aug 13];31(8):1683-7. Available at: https:// doi.org/10.1681/ASN.2020040432

10. Pedersen SF, Ho Y. SARS-CoV-2: a storm is raging. J Clin Invest. 2020 May 1 [cited 2020 Aug 13];130(5):2202-5. Available at: https://doi .org/10.1172/JCI137647

11. Mizuiri S, Ohashi Y. ACE and ACE2 in kidney disease. World J Nephrol. 2015 Feb 6;4(1):74-82. Available at: https://www.ncbi.nlm.nih.gov/pmc/ articles/pmid/25664248/

12. Gabarre $P$, Dumas $G$, Dupont $T$, Darmon $M$, Azoulay E, Zafrani L. Acute kidney injury in critically ill patients with COVID-19. Intensive Care Med. 2020 Jul [cited 2020 Aug 13];46(7):1339_ 48. Available at: https://link.springer.com/arti cle/10.1007/s00134-020-06153-9

13. Organización Panamericana de la Salud / Organización Mundial de la Salud. Alerta Epi- demiológica: COVID-19, complicaciones y secuelas. 12 de agosto de 2020 [Internet] Washington, D.C.: Pan American Health Organization; World Healt Organization; 2020 Aug 12 [cited 2020 Aug 13]. 17 p. Available at: https:// www.paho.org/es/documentos/alerta-epidemio logica-complicaciones-secuelas-por-covid -19-12-agosto-2020. Spanish.

14. Li M-Y, Li L, Zhang Y, Wang X-S. Expression of the SARS-CoV-2 cell receptor gene ACE2 in a wide variety of human tissues. Infect Dis Poverty. 2020 Apr 28 [cited 2020 Aug 13];9:45. Available at: https://doi.org/10.1186/s40249-020-00662-x

15. Batlle D, Soler MJ, Sparks MA, Hiremath S, South AM, Welling PA, et al. Acute kidney injury in COVID-19: emerging evidence of a distinct pathophysiology. J Am Soc Nephrol [Internet]. 2020 Jul [cited 2020 Aug 16];31(7):1380-3 Available at: https://jasn.asnjournals.org/con tent/31/7/1380.long

16. Naicker S, Yang C-W, Hwang S-J, Liu B-C, Chen $\mathrm{J}-\mathrm{H}$, Jha V. The Novel Coronavirus 2019 epidemic and kidneys. Kidney Int. 2020 May:97(5):8248. Available at: https://doi.org/10.1016/j.kint.2020 .03 .001

Submitted: September 13, 2020

Approved for publication: September 26, 2020 Disclosures: None

Correspondence: raul.herrera@infomed.sld.cu 


\section{MELI Ã}

\section{HAB ANA \\ CUBA}

THE LEVEL

Havana as a world-class international destination is further enhanced with The Level, a service that boasts attention to detail for business meetings, scientific events and successful negotiations.

The Meliá Habana shows its best colours, promising an unforgettable experience.

www.melia-habana.com

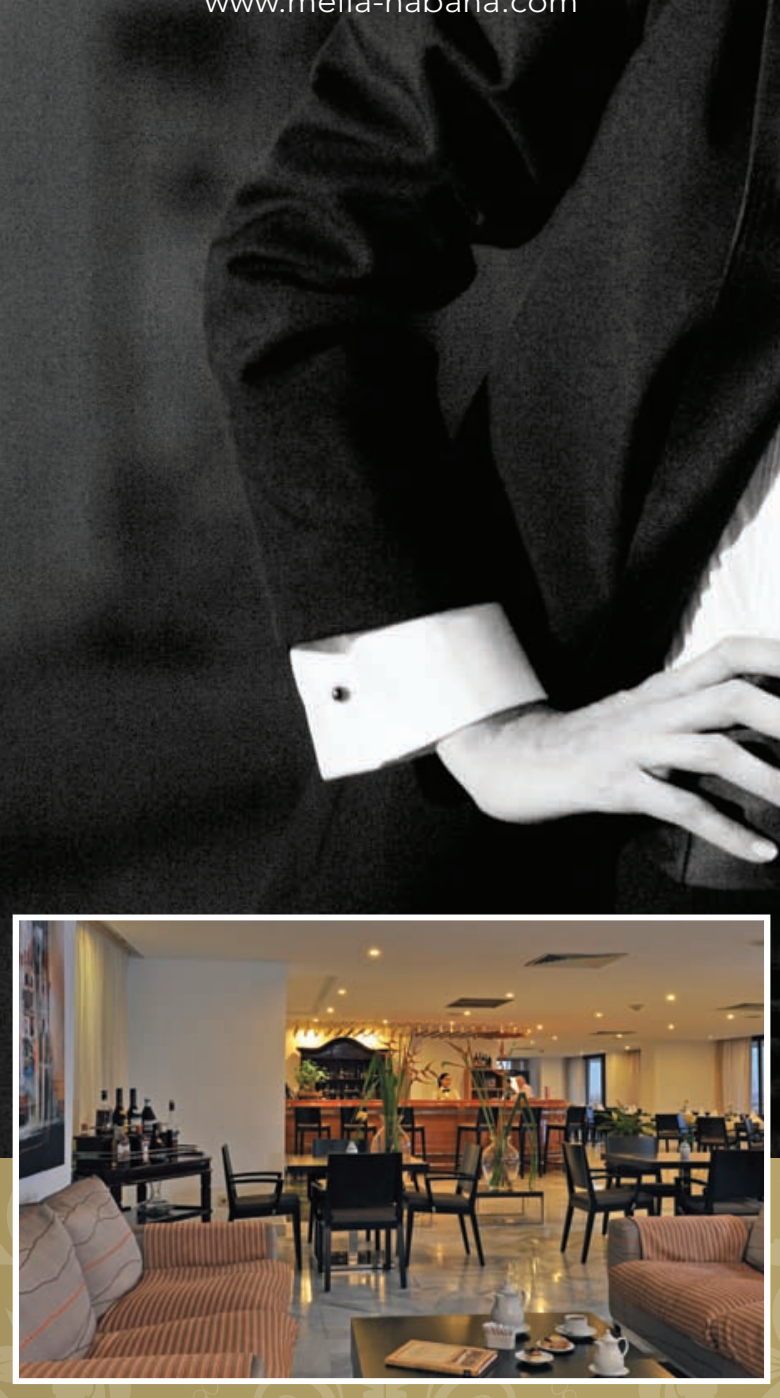

EX C E P T I O NA L

MELIA

HOTELS

INTERNATIONAL CUBA 
1714 Franklin Street, Suite 100-282 Oakland, CA 94612 USA www.mediccreview.org ISSN 1555-7960

$$
\begin{array}{|r|c}
\text { MIX } \\
\text { FSC } \\
\text { Faper from } \\
\text { responelble sources }
\end{array}
$$

